
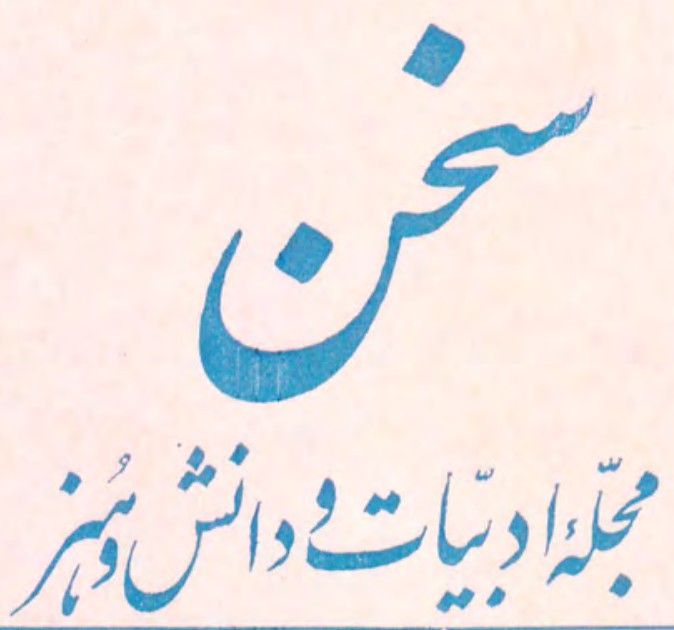

دورة بيستيت وششمم

\title{
: درا.ين شماره :
}

ماقات دربرج عاج ملاقات سفير يطاركبير باشاه سلمان حسين تركيب در زبان فارسى سلوفي جر ا انسانى خو است سو ساك شود

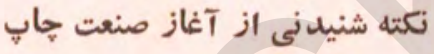

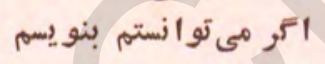
هدفهاى فرهنغى زبان آموزى نون تخت

عصرى كله انلديشه جو انه ميىزند نمايشنا،ه روز قصه دختر شاه يرز يان خلقت ديَّر

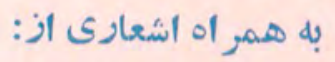
إووين بامداد - عباسحكيم - تقى يورنا مداريان - محملروضاى داور

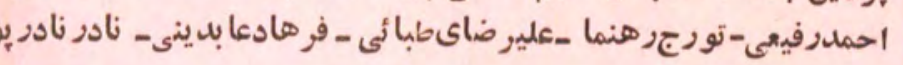

هوشنتك طاهرى الهم اسماعيل دو لتشاهى هاهي

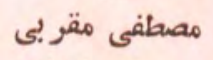
بهرام مقدادى مقريى محمادبير سياقى

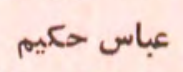
هو شنتَك مصالئى منصوره شريفزاهه رحيم نزا ادسليم يوويز مرزبان غلاموضا ستوده واسيله سوفىنتى

:

محملجواد برومنل سعيد على|اصغر بهشتى ميور مسعود رجب نيا محمل روشن 


\section{$\cos 50^{\circ}$}

صفحه

از

عنوان

rNH

د. Th

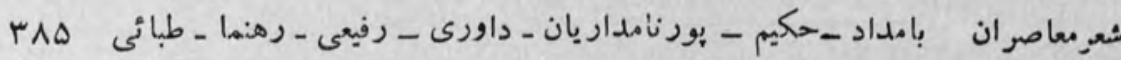
عا بدينى - نادريورد

एवद

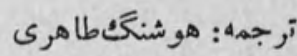

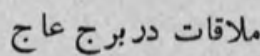

साI

ترجمة اسماعيل دو لتشاهنى مصنى

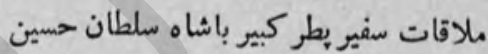

PYY

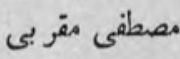

تركيب در زبان فارسى

PrY

YYD

بهر ام مقدادى مصن

. بهمل د بيرسياقى مقدادي

$Y \Delta \Delta$

$Y \Delta \Lambda$

rer

عباس حكيم

هوش:گَ مصلائى حكين

•تصورهشريف زاده

449

ترجمة : رحيم نثراد سليم

برويز مرزبان

PVD

غلامرضا ستوده هروبان

PVV

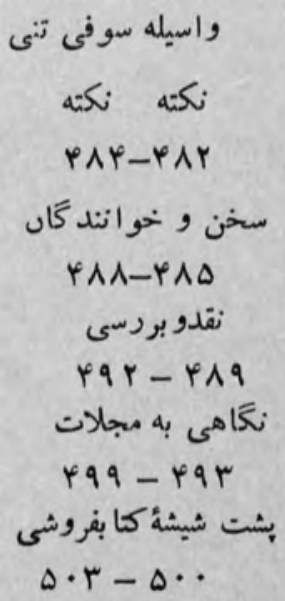



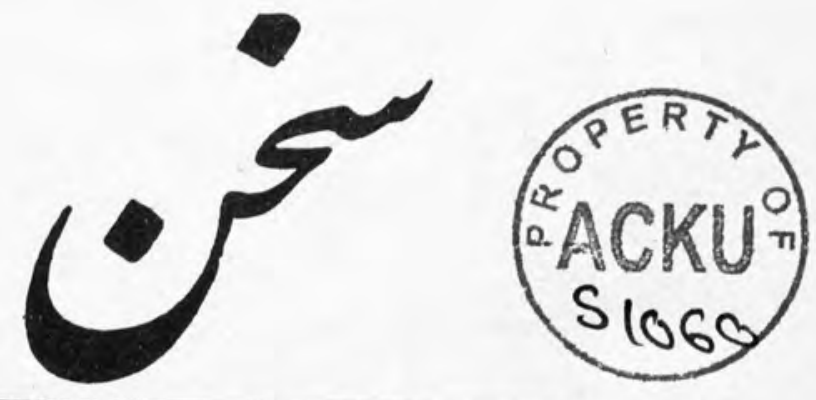

شمار8 جهارم

دورة بيست و ششم

اسفند ماه PAPY

$$
\text { بيا ، كه باز جانها را شهنشه باز مىخواند بهار آند }
$$
بيا ، كه كله را جويان به سوى دشت مىرانسـد

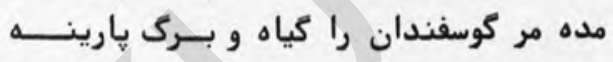

كه باغ و بيشه مىخندد ، كه برك بارينه تازه افشاند

بياييد اى درختانى كه ديتان حلهها بستد باغ بـد

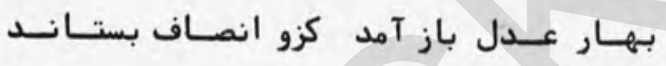

$$
\text { صلا زدهدهد وقمرى كه خندان شو دكر مكرى بار }
$$

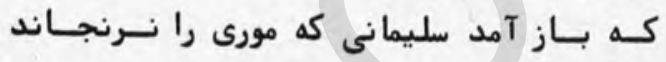

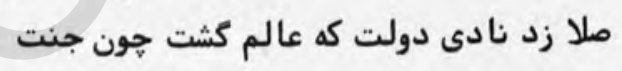

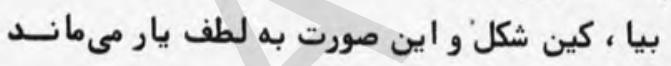

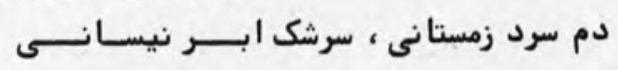

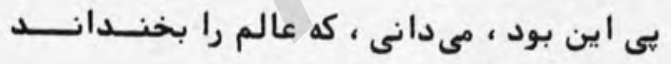

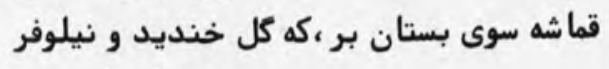

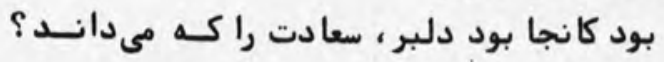

$$
\text { يقين آنجا ست آن جانان ، امير جشمهء حيوان }
$$

كه باغ مرده شد زنده ، و و جان بخشيدن او تانســ

$$
\text { جو اندر كلستان آيد ، كل و كلبــن سجودآرد }
$$

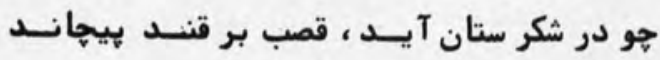

$$
\text { درختان همهو يعقوبان ، بديده يوسف خودرا }
$$

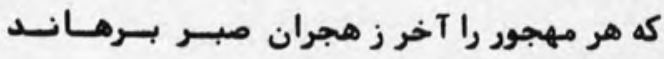

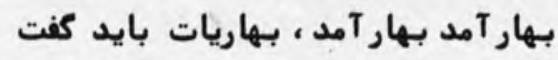

بكنترجيع ،تاكويم : "شكوفها زكجابشكتت باريد 
بهارست آن بهارست آن ،و ياروى نكارست آن درخت از باد مىرقصد كه هون من بى قرارست آن آن

$$
\text { زهى جمع يريزادان ، زهى كلــزار آبـادان }
$$

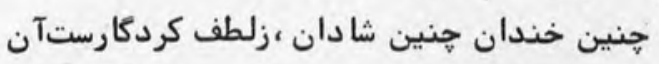

عجب باغ ضميرست آن ،مزاج شهدوشيرستآن و يا در مغز هر نغزى ، شراب بـ خمــارست آن

نهان سردر كريبانى ، دهان عنحه خنــدانى جرا ينهان همى خندد ؟ مكر از بيم خـارست آن

$$
\text { بهكهبرلاله هون مجنون ،جكرسوزيدهدل يرخون }
$$

زعشق دلبر موزون ،كه جون كلخوش عذاردارست

$$
\text { بخورى مىكند ريحان ، كه هنكام وصال مد دئ دورن }
$$

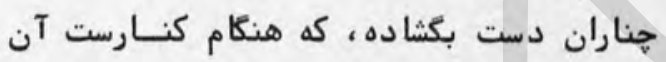

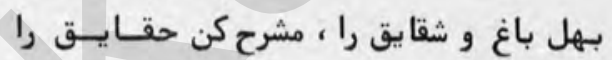

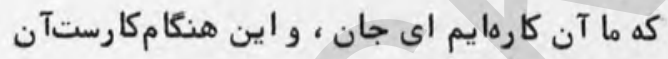

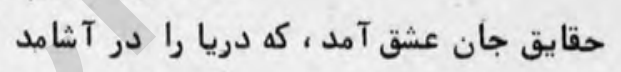

كه استسقاى حق دارد ، كه تشنــهء شهريارست آن ردار

$$
\text { درونش روضه و بستان ، بهار سبز بى بـايان }
$$

فراغت نيست خود او را ، كم از بيرون بهارست آن بان

$$
\begin{aligned}
& \text { در بـاغ خــرام ، جــون صبايى }
\end{aligned}
$$

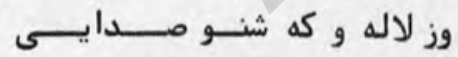

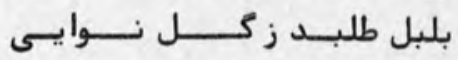

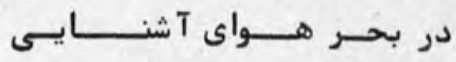

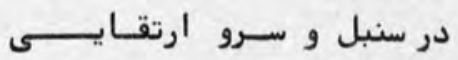

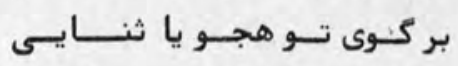

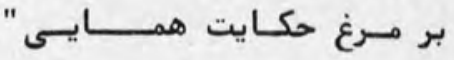

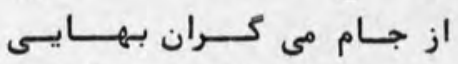

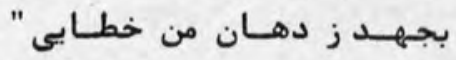

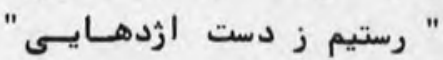

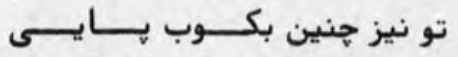

$$
\begin{aligned}
& \text { مولوى (ديوان شمس) بكاب لئ }
\end{aligned}
$$

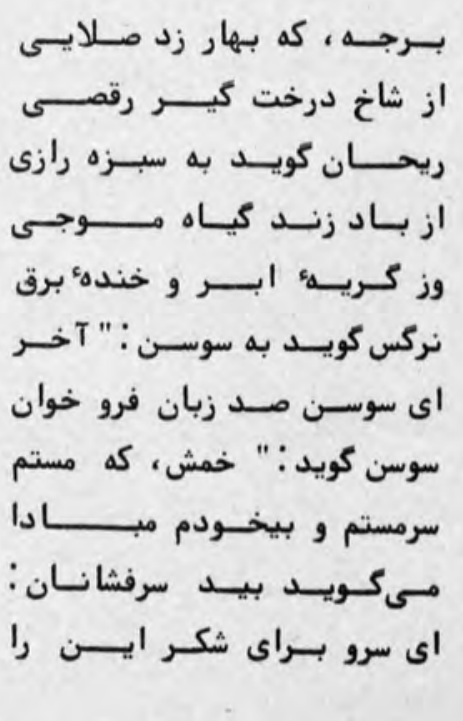




\section{شعر معاصران}

بيعازه دربهشت

در كافه ، دود و غلغله يِيجيده

كي مىزنند مردم و مىخندند

آغوش, در به روى خوشى باز است از بيم ناخوشى است كه مي بندند

در بركرفته يارى اكر يارى ،

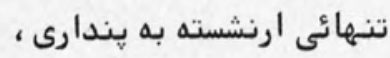

كوئى كه عالم است و جنين كارى !

هر سوى مى درخشد و مىسوزد

كوى بلور شعله ور جامى :

جانى به نيمه جان دكر برلب

تا بسيرد به نوش لبى كامى .

فنجان حاى و قهوه بر آرد آه

جون عاشقى برابر دلدارى ، تا دور انتظار شود كوتاه

بوسد به داغى آن لب شيرين را.

اما ، زمان بى خبرى ، شيدا،

دامن كشد به نرمى و ناز اينجا 


$$
\text { نوشند با فراغت و آرامى }
$$

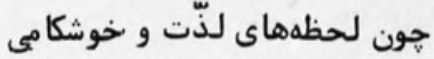

هر قطرهاى زمايع نوشين را ل...

آنسوى شيشه هاى بخار آلود نيلوفران حتره شتا بانند

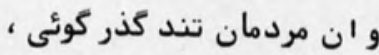

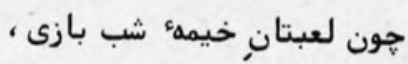
در بندهاى نازك بارانند .

موّاج و زنده ،كوحهء بارانى است كوئى زمين شهر ، هراغانى است .

$$
\begin{aligned}
& \text { خاريس مىتيد جو دلى ، هر دم ، } \\
& \text { با شور و شوق و شادى مستانه } \\
& \text { شهرى است جون بهشت ، ولى ولى افسوس! } \\
& \text { من آن جهنّمى زن بيكانه . ... }
\end{aligned}
$$

$$
\begin{aligned}
& \text { إريس - سال } \\
& \text { بروين بامداد }
\end{aligned}
$$

$$
\begin{aligned}
& \text { رشك } \\
& \text { به برادر بزركترم ، }
\end{aligned}
$$

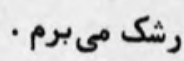

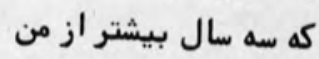

$$
\begin{aligned}
& \text { مادر داشته است. }
\end{aligned}
$$

$$
\begin{aligned}
& \text { تهران - } \\
& \text { عباس حكيم }
\end{aligned}
$$


نسيـــم زلــف دلاويـز يــار مى آيـد

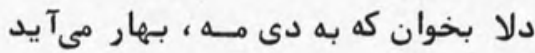

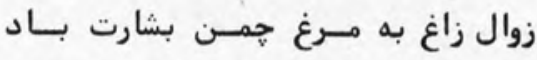

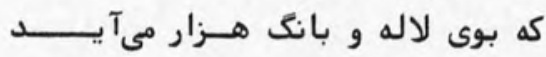

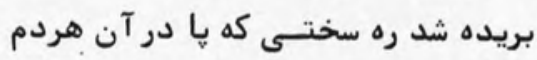

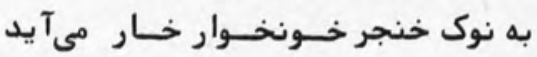

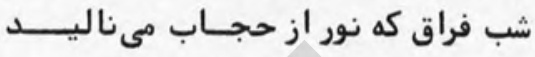

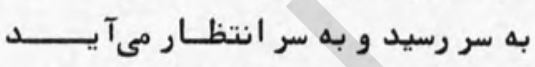
ازآن درخت كه در خاك آن جهان كشتم

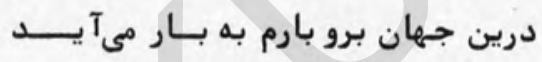

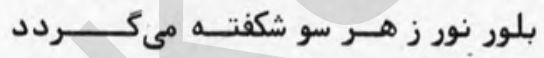

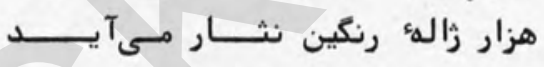

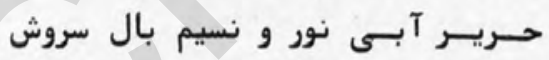

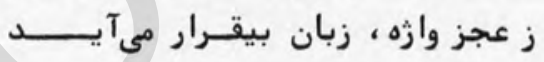

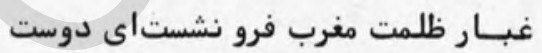

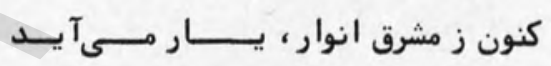

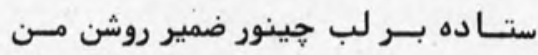

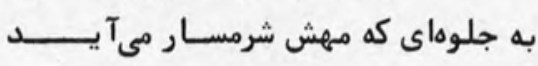

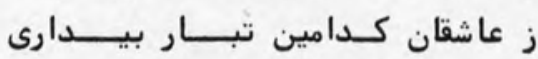

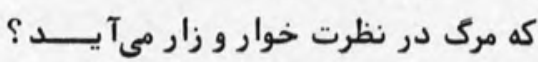

I سفند ماه تقى بيورنامداريان

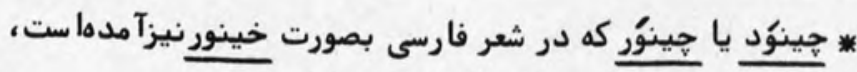

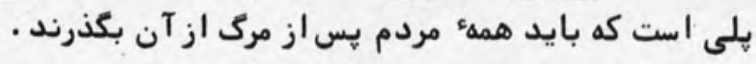


به: : شهزاد طلاكار

$$
\begin{aligned}
& \text { اى تو از نسل غزالان بيابانى، }
\end{aligned}
$$

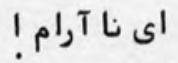

$$
\begin{aligned}
& \text { به كجاى شب اين ينجره آويختهاى؟ }
\end{aligned}
$$

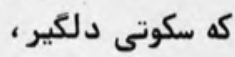

$$
\begin{aligned}
& \text { ريخته بر سر آب ، ولكير، }
\end{aligned}
$$

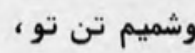

$$
\begin{aligned}
& \text { كم شده در نفس خستهى باغ تون ... } \\
& \text { اي تو سر قصل غزل هاى خيابانى ، }
\end{aligned}
$$

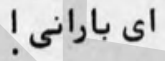

$$
\begin{aligned}
& \text { با كدامين كيسو ، }
\end{aligned}
$$

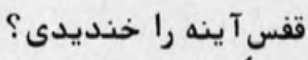

$$
\begin{aligned}
& \text { كه تمثّاى تو دارد كذر شانه و آب . ... }
\end{aligned}
$$
من نُر از يأسم و ترديد و درنك، 
rA شعر معاصران

$$
\text { ، درين تاريكى }
$$

و درين رخوت, مرطوب نسيم ،

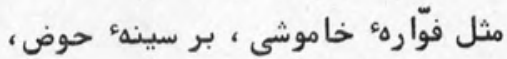

مثل يك ينجره ،

بر قامت, شب .

مثل يك فاجعه ،

$$
\begin{aligned}
& \text { در تاريكى مىكذرم } \\
& \text { و كسى را با من كارى نيست ، } \\
& \text { آسمان را ، حَّا ... . . }
\end{aligned}
$$

سوختن ، آ سان است .

ساختن ، آ سان نيست ، . . . سان ل

محمّد رضاى داورى - مل

شاءرتو.ين

براى" ف .

$$
\begin{aligned}
& \text { تو ، شاعرترينى ! } \\
& \text { و در آن غروب غم آلود } \\
& \text { به خورشيد ، آموختى شاعرى را . . . } \\
& \text { تو رفتى ، شب آمد - عبوس و دل آزار ـ } \\
& \text { و باران اندوه، بر شهر ، باريده } \\
& \text { فضا را سكوتى ير از بغض ير كرد ، } \\
& \text { و جز هق هق كريماى تلخ } \\
& \text { صدائى نييهيد در زير اين سقف . .. }
\end{aligned}
$$

تو رفتى و سرحشمهُ مهر خشكيد 


$$
\begin{aligned}
& \text { كل عشق و خورشيد و مهتاب • يزمرد }
\end{aligned}
$$

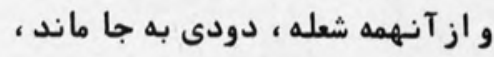

$$
\begin{aligned}
& \text { و مردى كه در زير باران اندوه }
\end{aligned}
$$

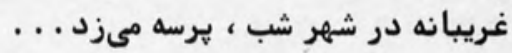

$$
\begin{aligned}
& \text { تو ، در آن غروب غم آلود } \\
& \text { درخشانترين شعرها را سرودى ... } \\
& \text { - تو ، شاعرترينى ! }
\end{aligned}
$$

تهوان - م 1 خرداد ماه

احمد رفيعى

در خانهاى به كوجكى يـك بغض

در من - در اين سكوت, سترون د يرى است

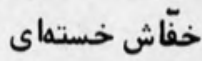

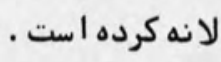

$$
\begin{aligned}
& \text { خَّاش هير }
\end{aligned}
$$

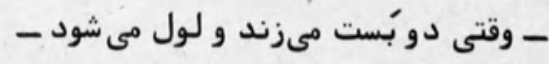

$$
\begin{aligned}
& \text { كاهى براى من }
\end{aligned}
$$

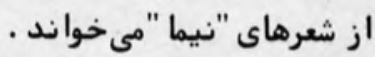

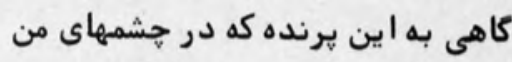

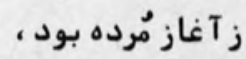

$$
\begin{aligned}
& \text { مىكويد : زاز مرده }
\end{aligned}
$$

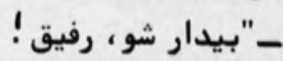

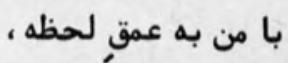

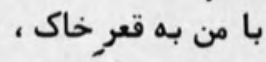


شq1 شعر معاصران

با من به ذهن, سرخ, شقايق رسوب كن'؛ "

$$
\text { احساس مىكنم }
$$

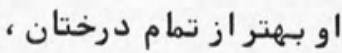

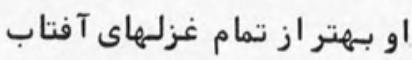

مى

من كيستم

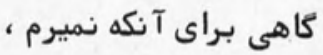

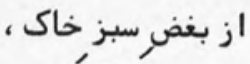

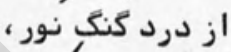

تعريف مىكند .

كاهى براى آنكه نميرم

از بحّهماى كوجه ، برايم

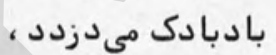

، يا از نماز خانهء مغمومى بـى

يك 'مهر

تا نماز بخوانم

$$
\begin{aligned}
& \text { كاهى براى حند صباحى } \\
& \text { كم مى شود . }
\end{aligned}
$$

هنكام بازكشت

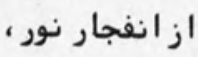

از رويش بسهار خبنز دارد .

(آماً دروغ مىكويد ،مىدانم · )

خفّاش یير و من 
در خانهاى به كوجكى يك بغض، شب را ميان خويش تقسيم مىكنيم .

تورج رهنمـا - ت ت ت

$$
\begin{aligned}
& \text { موداب } \\
& \text { بركرد خويش ،بنكر : } \\
& \text { تنهائى ..... بركرد خويش ، بنكر } \\
& \text { * * } \\
& \text { داس بلند ، }
\end{aligned}
$$

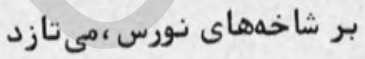

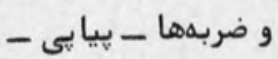

$$
\begin{aligned}
& \text { بر شاخهما فرود مى آيد .... }
\end{aligned}
$$

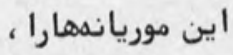

$$
\begin{aligned}
& \text { - مى بينى؟ }
\end{aligned}
$$

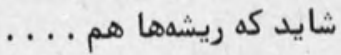

$$
\begin{aligned}
& \text { * * } \\
& \text { اينك ،نكاه كن : } \\
& \text { طاعون! } \\
& \text { ** } \\
& \text { بر آسمانه ، بـنكر : }
\end{aligned}
$$

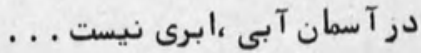

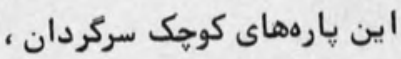

$$
\begin{aligned}
& \text { كلبركهاى نقرهاى برف نيستند : } \\
& \text { خاكستر رها شده در بادند برداي }
\end{aligned}
$$

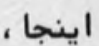


شعر معاصران

$$
\begin{aligned}
& \text { ديريست برفراز سرتو ، درباري مداوم } \\
& \text { دربارش مداوم خاكستر }
\end{aligned}
$$

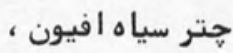

$$
\begin{aligned}
& \text { افرا شته است ستون } \\
& \text { * * } \\
& \text { مرداب كرسنه' }
\end{aligned}
$$

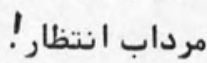

$$
\begin{aligned}
& \text { * }
\end{aligned}
$$

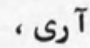

$$
\begin{aligned}
& \text { - من آن درخت ،هيى دستم } \\
& \text { وان ميوهء يكانهء شيرين را }
\end{aligned}
$$

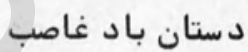

$$
\begin{aligned}
& \text { از شاخه ،بىهراس ،فرو هيده است بـ }
\end{aligned}
$$

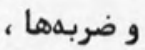

$$
\begin{aligned}
& \text { - بيايايى - } \\
& \text { بر هيكرم فرود مى آيد . } \\
& \text { * * }
\end{aligned}
$$

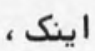

$$
\begin{aligned}
& \text { نطع كرسنه } \\
& \text { - مرداب } \\
& \text { بيذير . . . }
\end{aligned}
$$

عليرضاى طباءٔى 


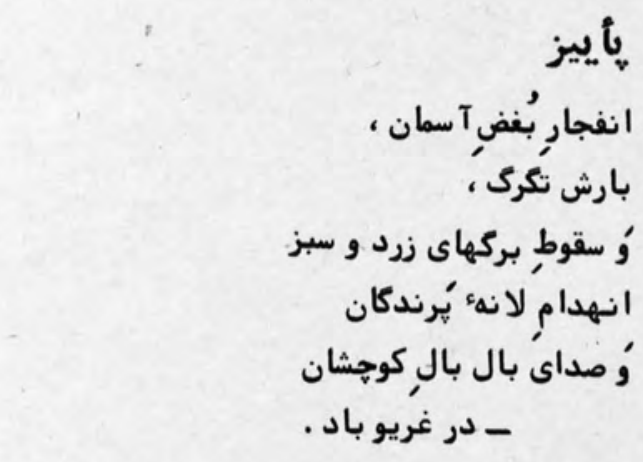

$$
\begin{aligned}
& \text { عُمقدهاى آسمان حنان كشوده شد } \\
& \text { كه تمام شاخهماى نازٔك, درختهان }
\end{aligned}
$$

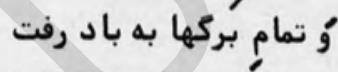

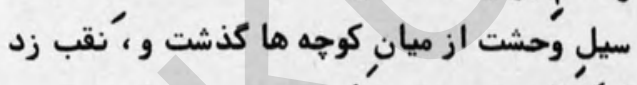

$$
\begin{aligned}
& \text { از 'خزان به سردى بهار. }
\end{aligned}
$$

تهوان - أذرماه ع هاه ,

$$
\text { فرهاد عابدينى }
$$


تو مثل تُنك شرابى ،كه ماريّيج بلور

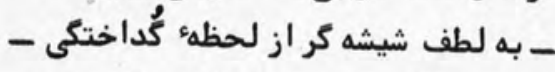

حو موج زلف بر اندام نازكش جاريست ،

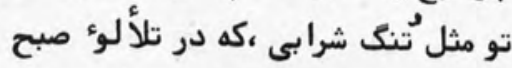

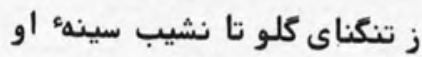

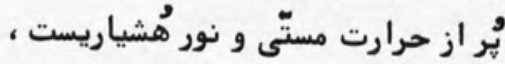
تو مثل تنك شرابى ،تو مثل شعر منى •

حكونه نازكىات را نديده انكارم؟ جكونه كاه نينديشماز شكستن تو؟ جو بشكنى ، عطشم را به خاك مى فكنى •

تو همزبان كُل و همنشين آ ينهاى : طلوع دمبدمت از ميان اين دو خوش است ، تو ، آفتاب در آفاق حشمه و حمنى •

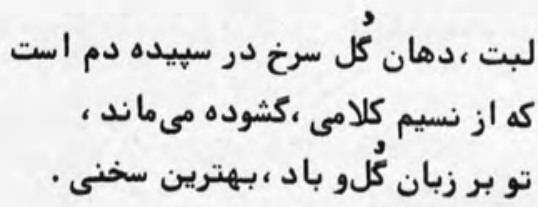

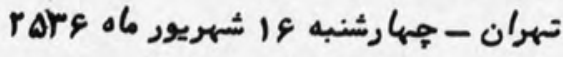

$$
\text { أيا بُلور بُلند! }
$$

مرا شراب كن و در كلوى خويش بريز ، بورن

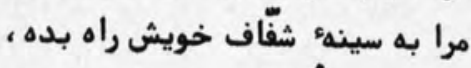

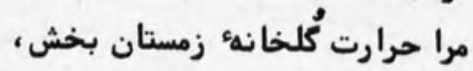

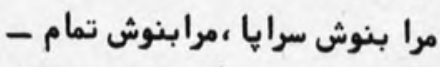

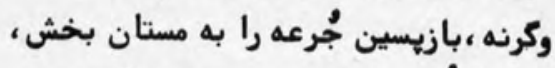

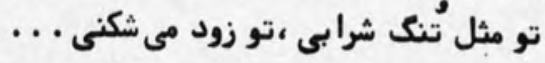
نادر نادريور 


\section{ماريا آنتونيتا ماجوكي Moria Antonieta-Macciocchi}

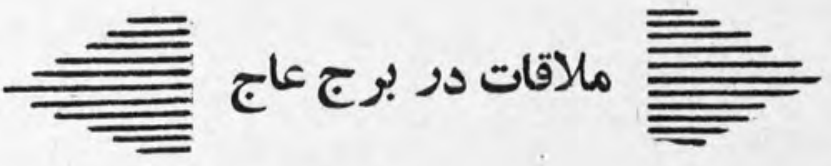

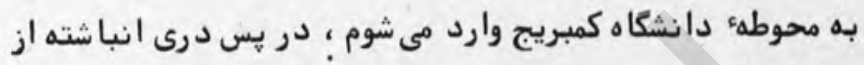

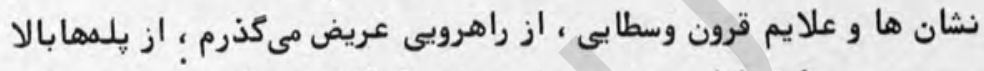

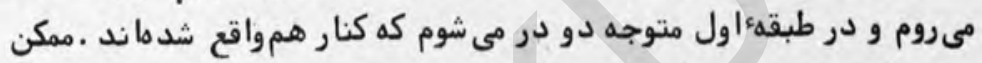

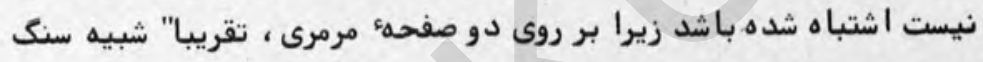

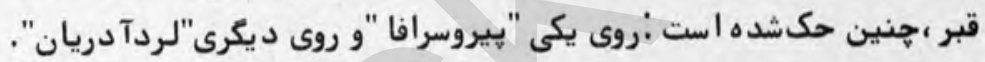

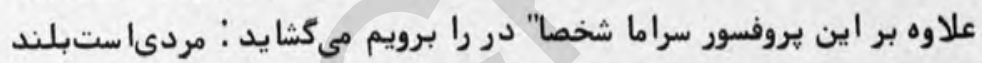

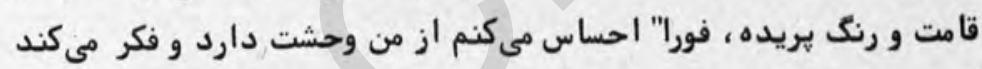

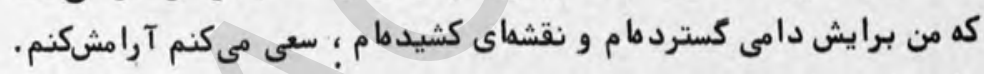

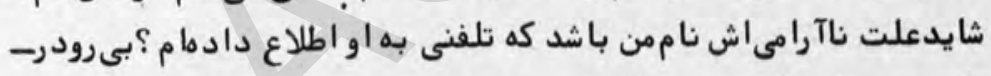

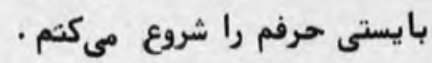

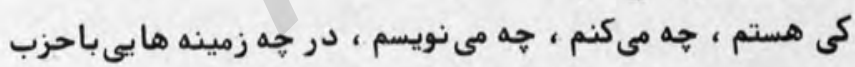

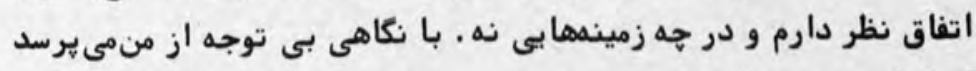

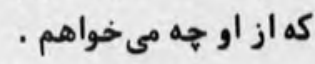

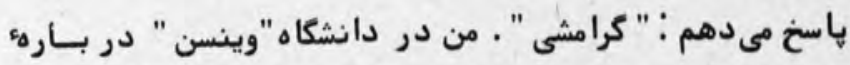

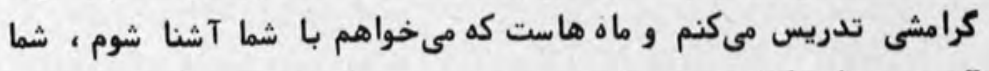

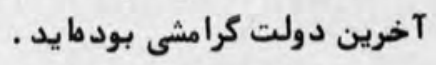

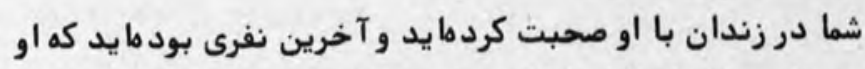

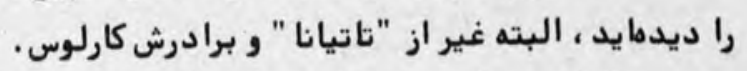

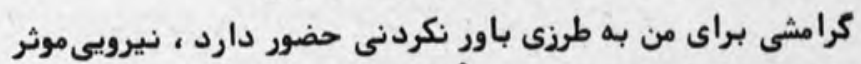

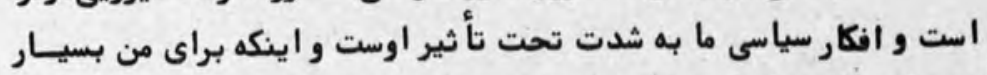

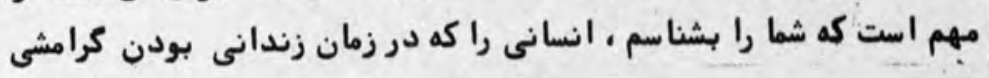




$$
\text { دركنارش بوده است " ماست }
$$

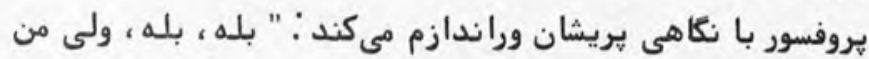

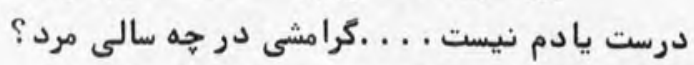

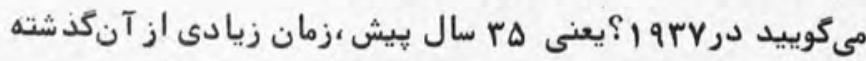

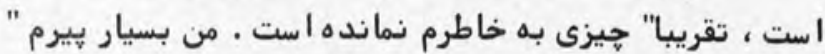

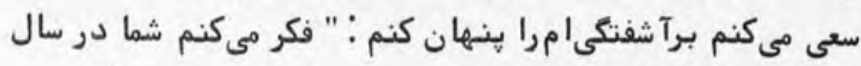

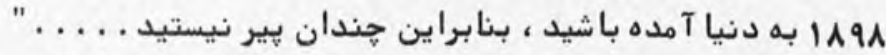

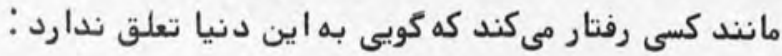

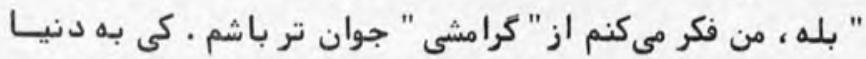

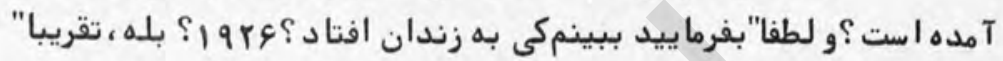

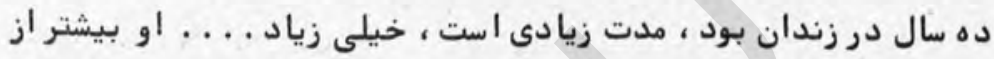

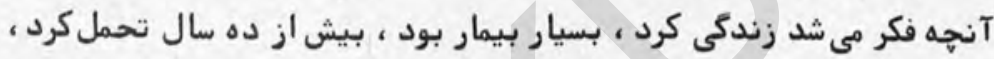

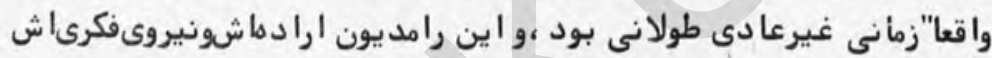

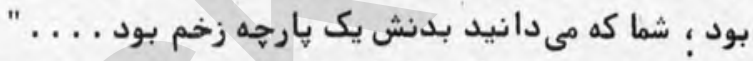

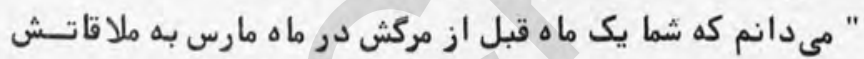

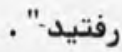

" بله ، اما كجا ؟ از اين ها كذشته به من بكوييد كه او دركجامرد؟

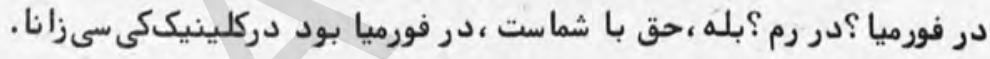

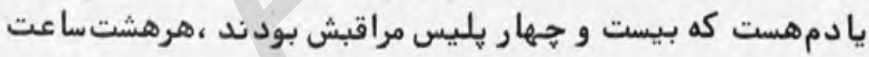

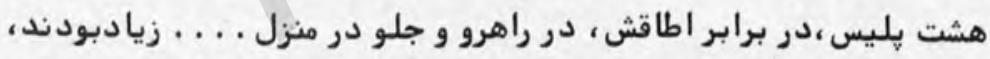

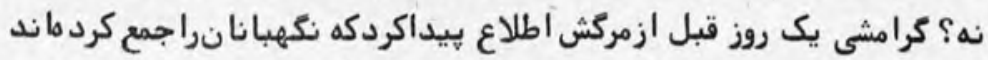

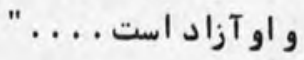

بروفسورنفس نفس مى زندو به طورطبيعى تعريف مى كندكميليسهاى

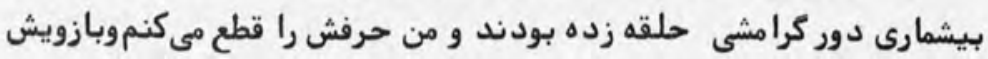

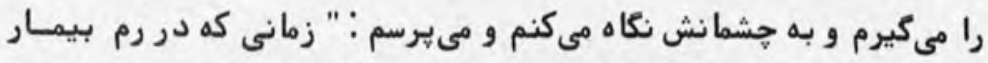

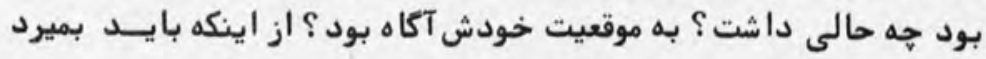
د ستخوش آشفتكى نبود ؟ به شما حه كفت ؟

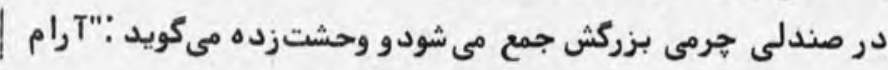


بود ، درك مىكرد و حتى راضى به نظر مى رسيد ـ ديكر دلش نمى بـــــاست

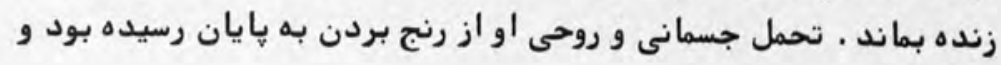

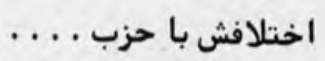

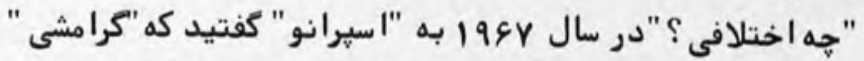

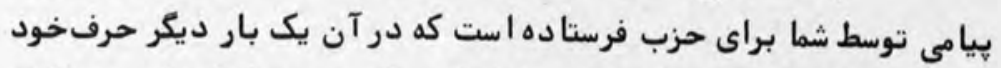

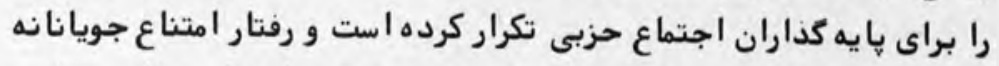

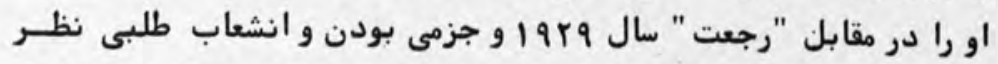

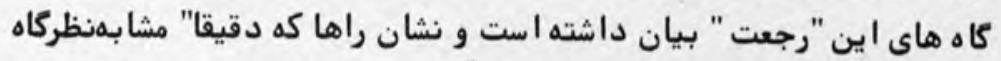

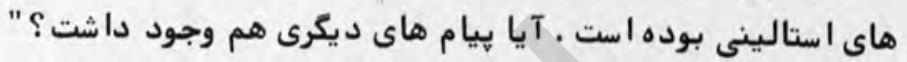

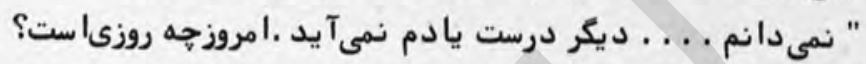

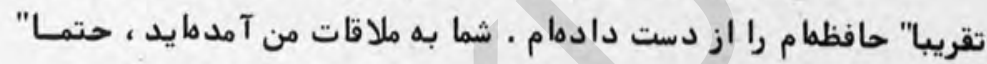

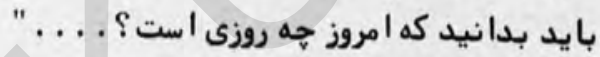

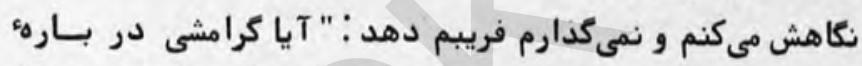

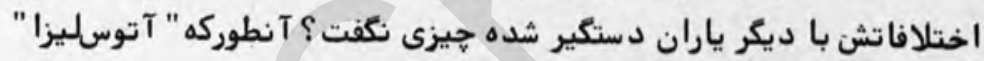

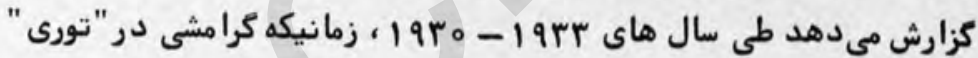

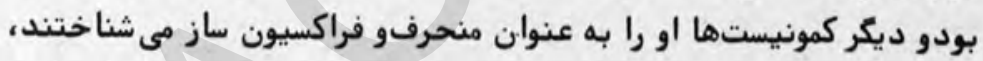

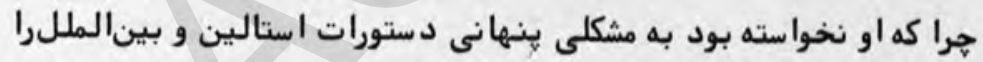

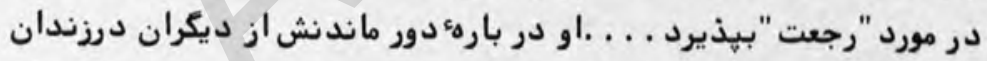

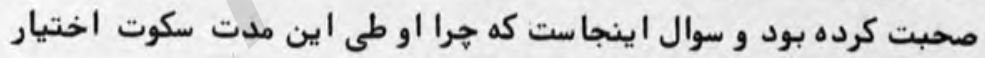

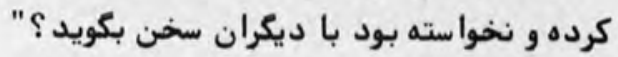

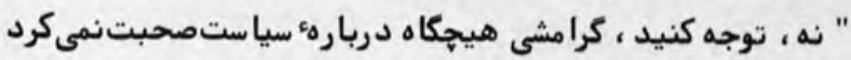

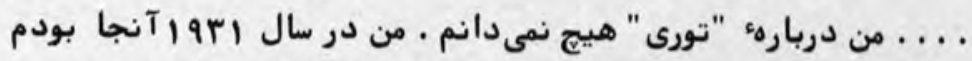

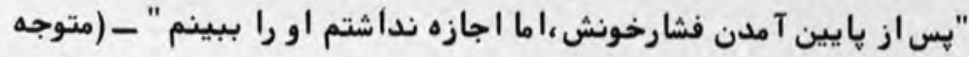

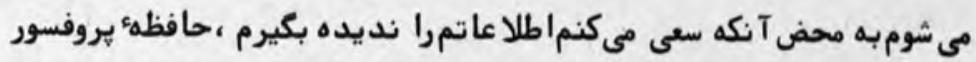

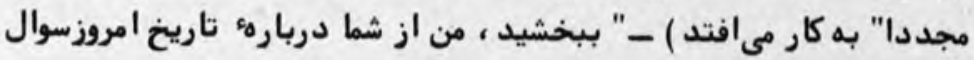
كردم با كمى خشونت جواب مى دهم" "| ماه مه rara ا ـ راستى ممكـن 
است به من جواببدهيد اكر كرامبى زنده مى ماند ،ميل داشت كجابرود؟"

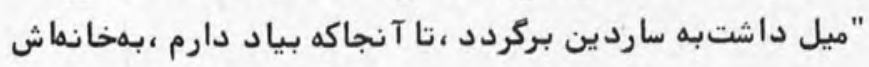

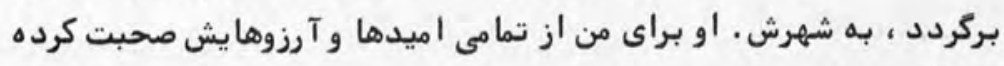
بود" بركرد "

" هيج دلش نمى خواست با كميته مركزى حزب تماس بكيرد و بــا

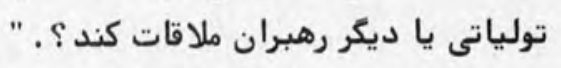

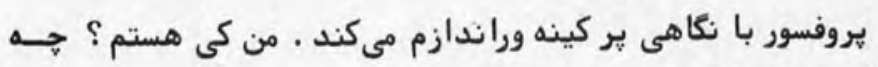

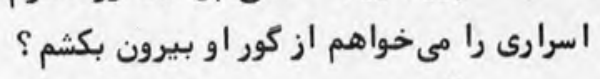

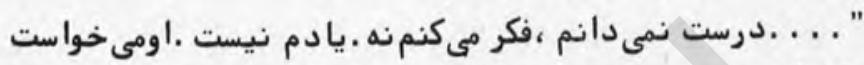

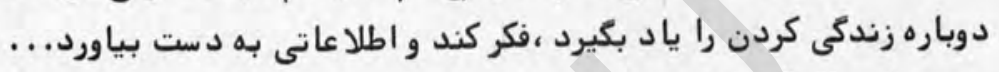

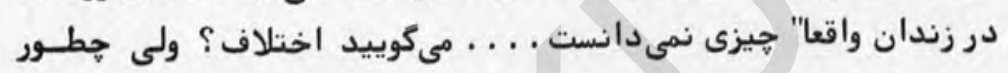

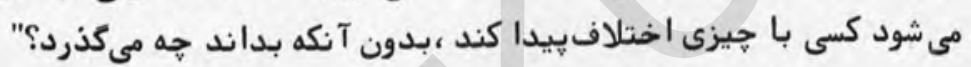

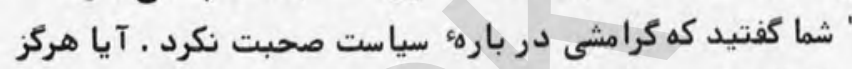

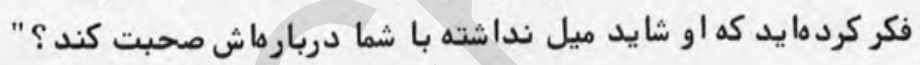

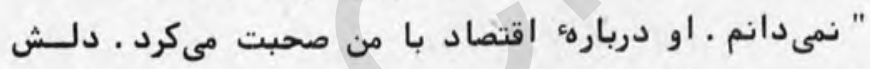

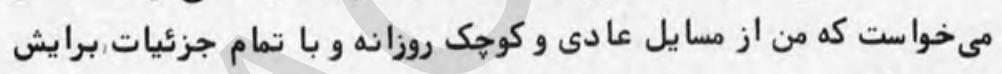
صحبت كنم

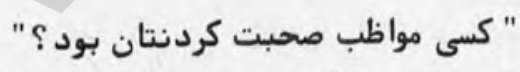

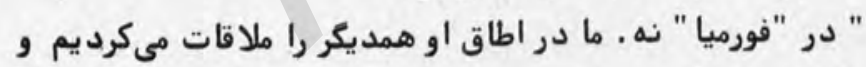

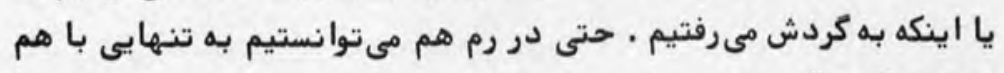

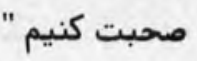

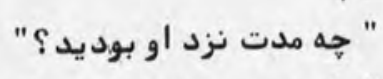

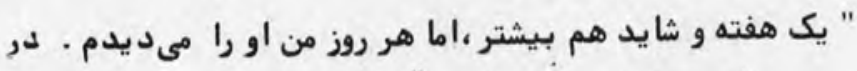

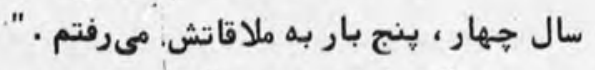

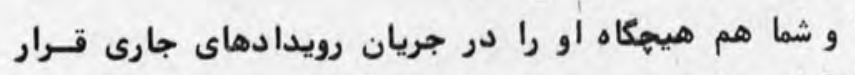

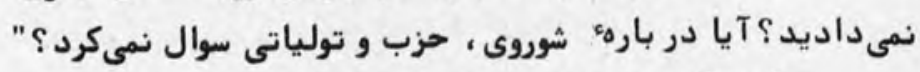

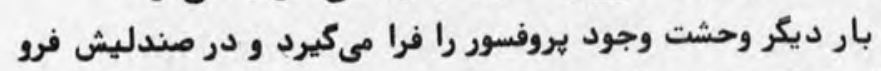

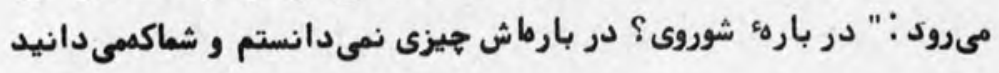


من واقعا" علاقهاى به سياست ندارم ـ من اقتصاد دان هستم

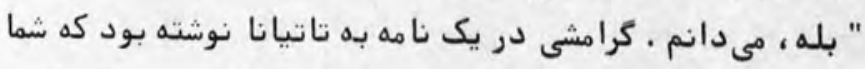

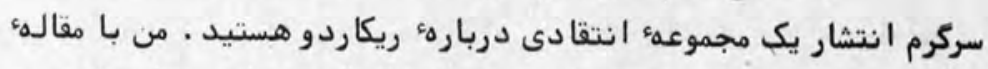

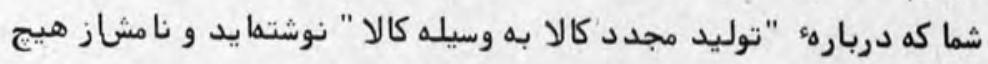

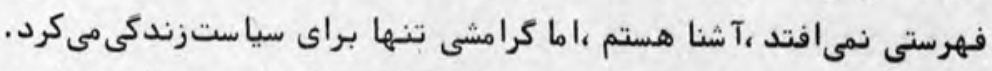

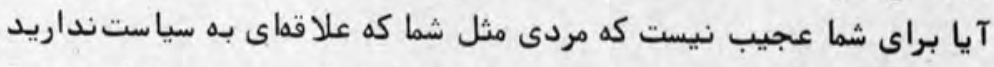

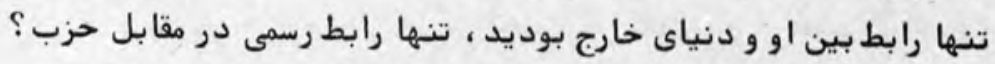

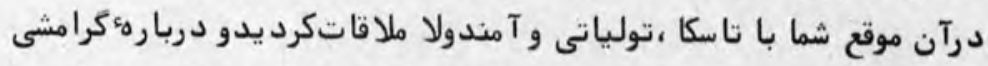

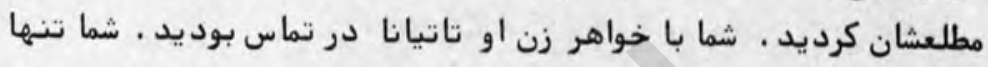

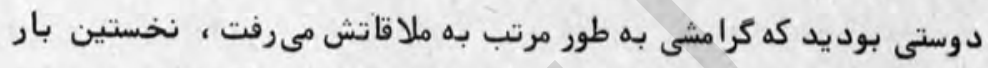

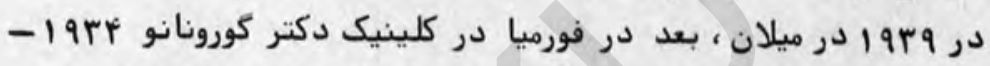

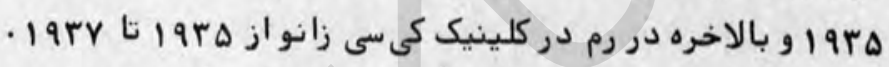
"من استاد دانشكاه كمبريج بودم .مناز زمان (Ordine Nuovo)

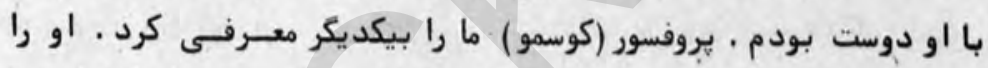

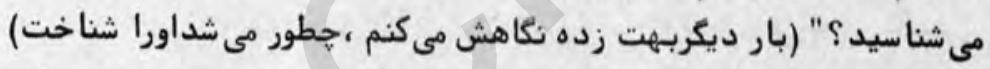

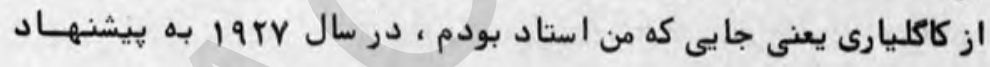

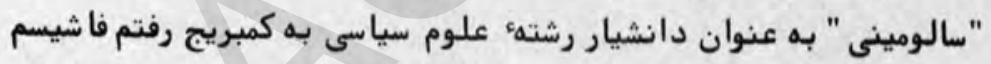

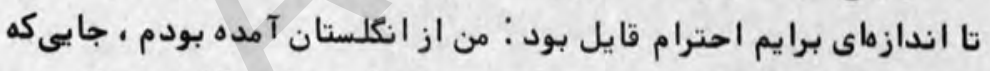

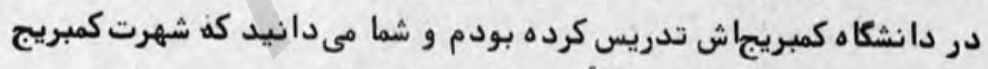

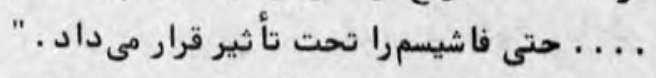

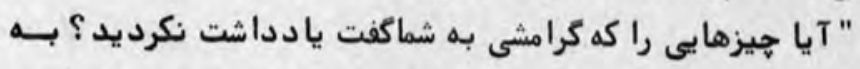

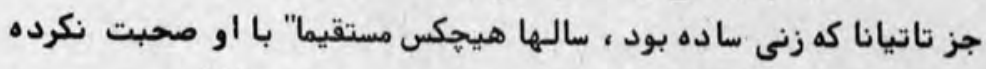

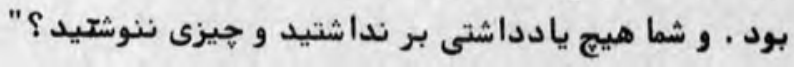

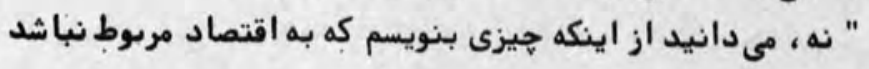

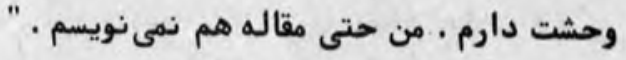

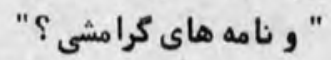

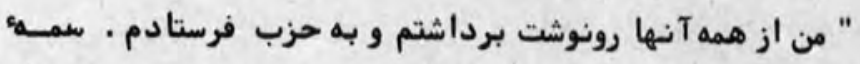

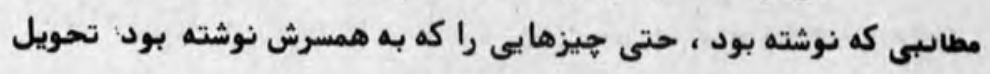


خواهر زنش تاتيانا دادند كه در سفارت شوروى در رم كار مىكرد . و بعـد آند

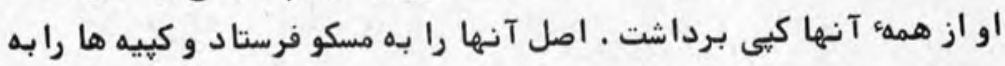

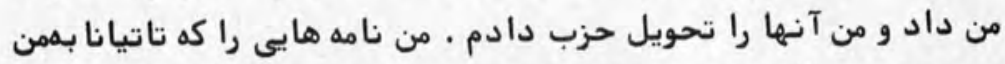

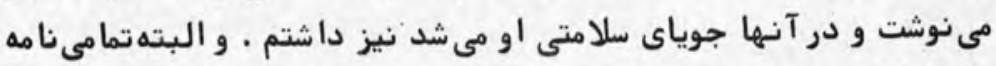

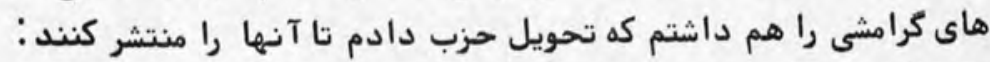

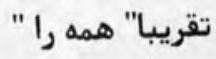

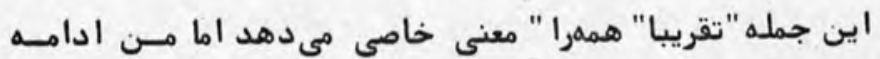

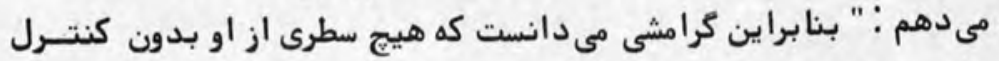

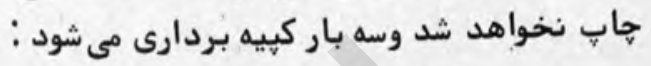

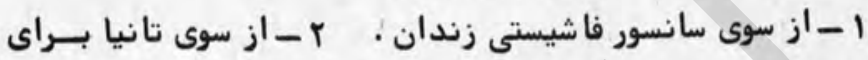

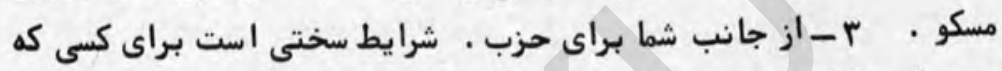

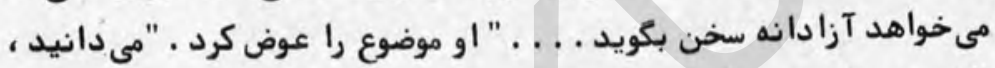

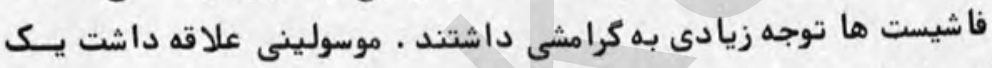

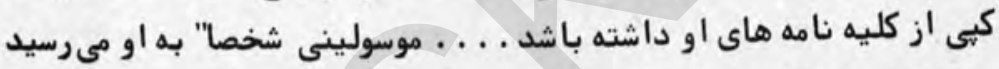

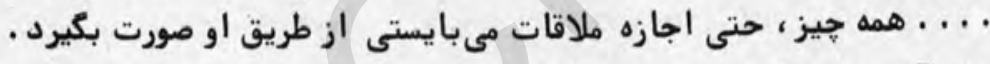

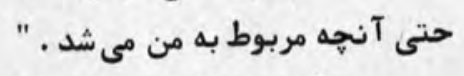

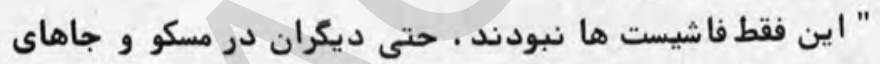

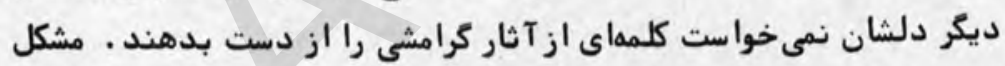

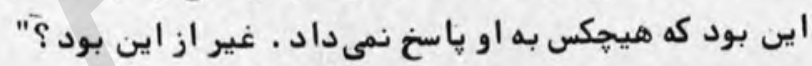

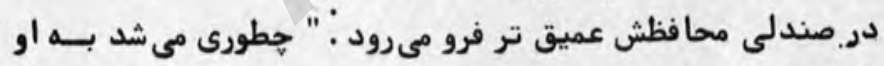

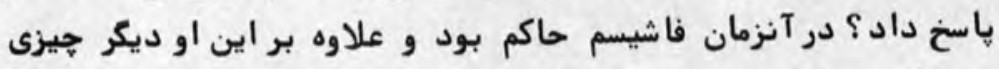

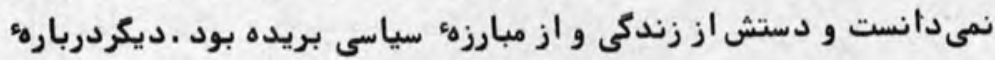

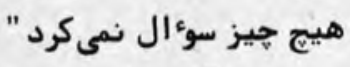

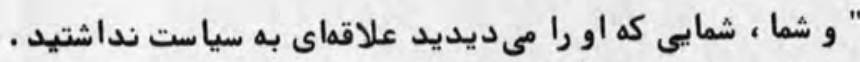

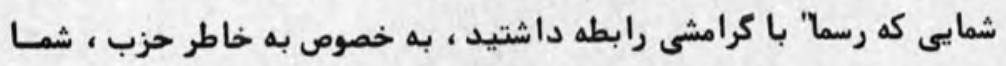

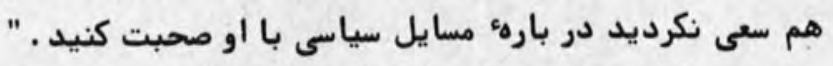

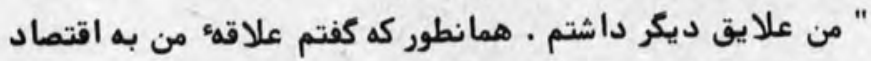

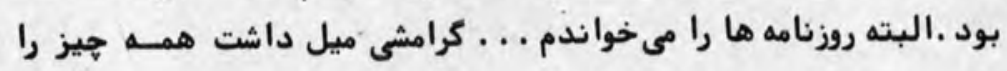


من سعى داشتم دربارهء همه هيز حتى حتى اخبار مغشوش او را آكـاه

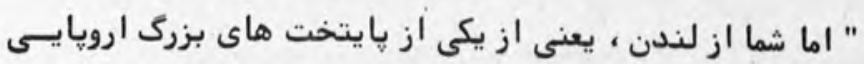
سازم

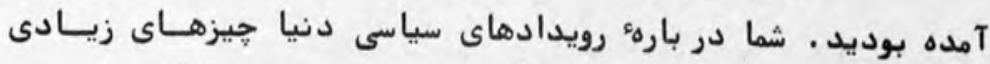

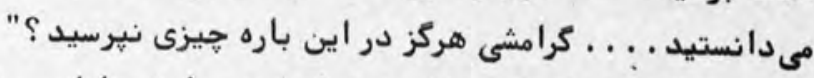

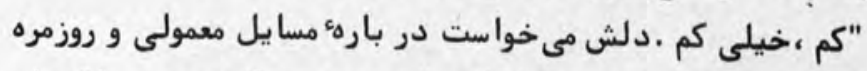

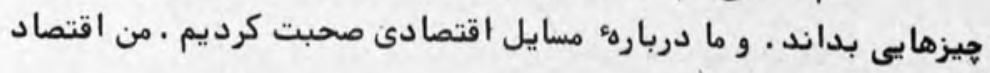

"راستى دربارهء بحثهايتان با كرامشى به حزبكزارشىنداديد؟

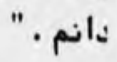

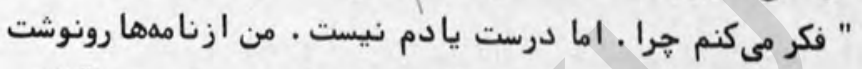

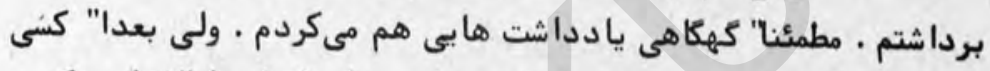

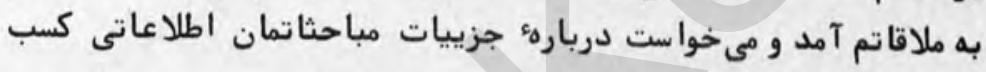
كند..... به ملاقات آمث

" تصور نمىكنيد كه كرامشى در برخوردش باشما تا اندازهاىجانب

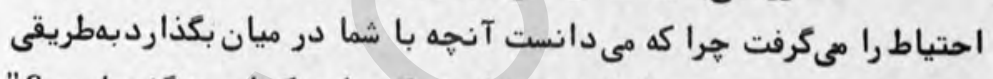

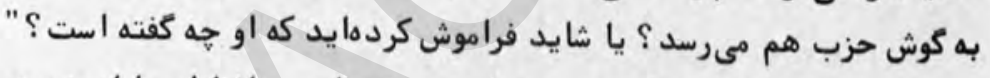

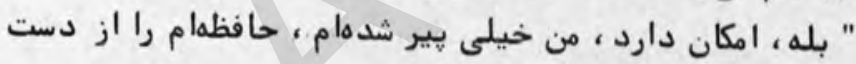

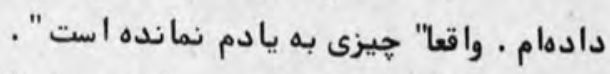

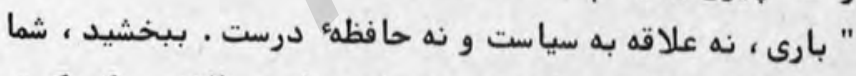

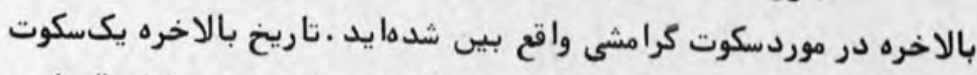

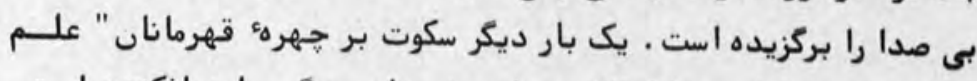

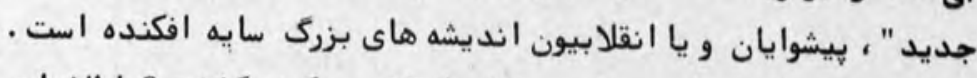

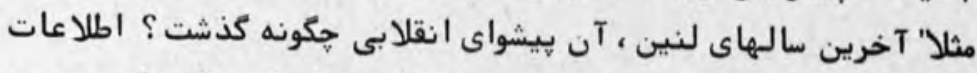

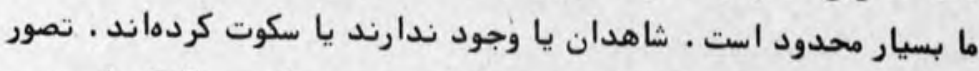

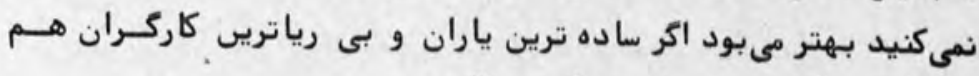

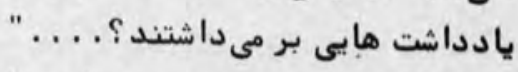

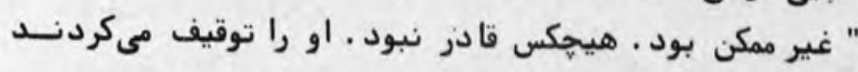


"اما به شما اطمينان داشتند .

" هما نطور كه برايتان كفتم ، من استاد دانشكاه كمبريج بودم"

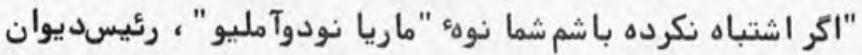
عالى تميز فاشيستى هستيد ، اين را كرامشى در نامهاى كه به سال وبه نوشته ابراز كرده است . او در اين نامه مى نويسد كه به اين علت به جانب شماروى آورده است كه مردم بدانند كه بر سر تقاضاى تجديد نظر كـه "تراحين" يكسال قبل از آن با نام كامل ارائه داده بود جهه آمده اســت .

$$
\text { هركز در اين باره فكر نكردها يد؟ }
$$

بيذيريم كه اين اشتياق وجود داشت كه هيع سندى از " كرامشى" ئى زندانى باقى نماند • جهه كسى مى توانست بـهتر به اين هدف واقعى بــرسد

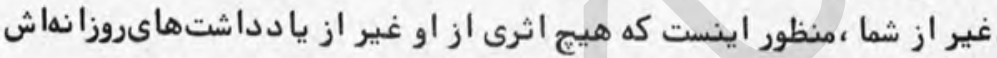
و نامه هايي كه از طرف موء سنسهانسور شده بود بر جاى نماند . "

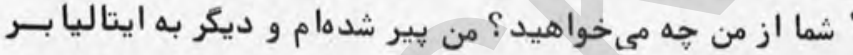
نخواهم كشت .دوستان مىميرند . شما اينرا مى دانستيد ؟ هرباريكى نايديد

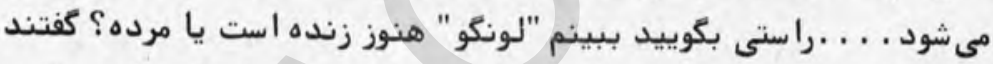
زنده است ؟ جالب است . . . . خانم كرامشى هطور؟ كه اينطور ،اوهم هنوز زنده است . جه خصوصيات اخلاقى اى ابحههها يش حطور ؟هنوز در روسيها ند ؟

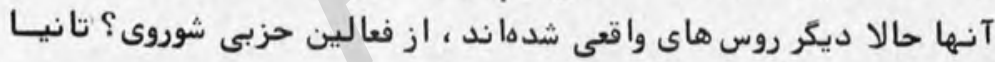

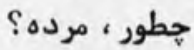
" بله ، او دو سال يس ازمرك كرامشى از شدت غصه بدرودزندكى

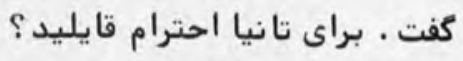

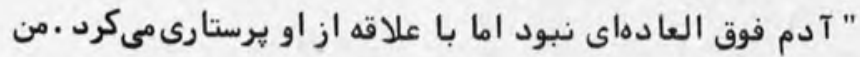
هنوز نامه هاى او را كه دربارهء كرامشى است دارم ؛ نامههاينى كه مملــو از اشتباهات لغوى است هرا كه ايتاليا بيى را به درستى نمى هدانست .

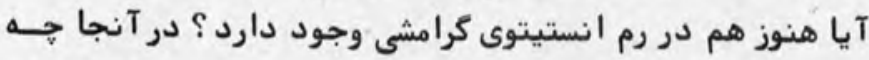
عملى انجام مى دهند؟ آيا در بارهء فعاليت هاى كرامشى در حزب بروسى هري 
دورهن fof

" انستيتو شباهت به يك كتابخانهء نسبتا" بزرك دارد . ب بسيـار

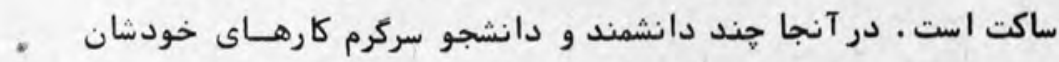

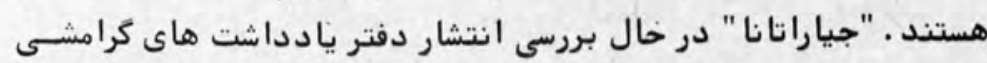

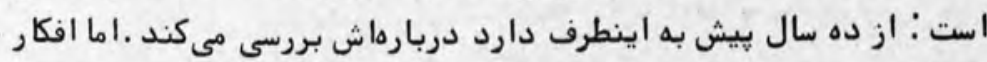

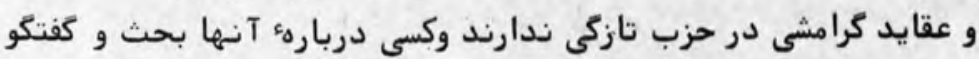

استاد مىخندد ، شايد به سبب مقايسهء با كتابخانه باشد كه اورا

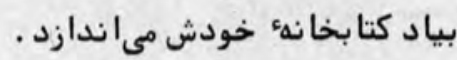

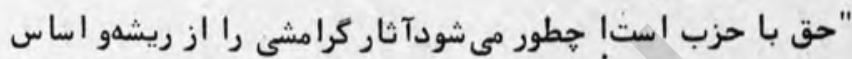

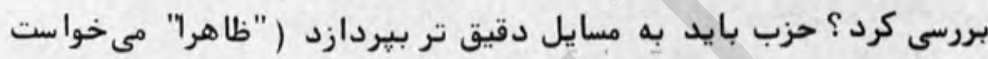

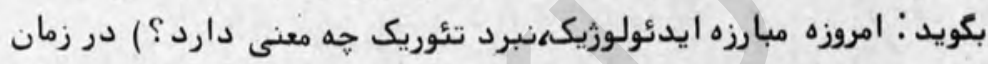

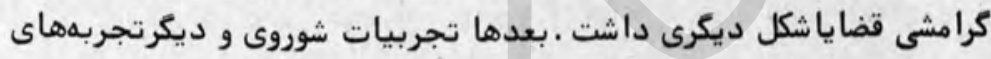

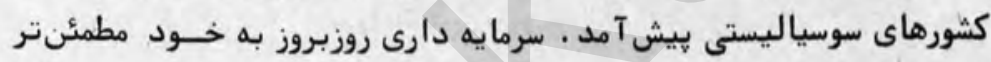

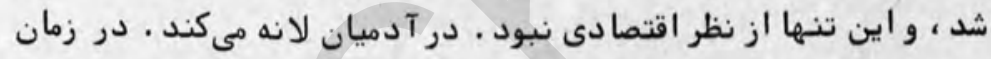

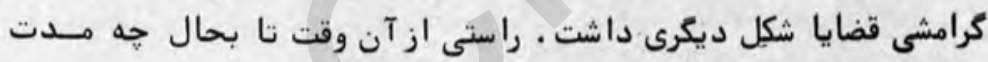

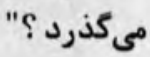

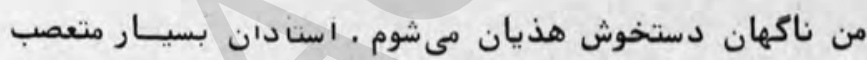

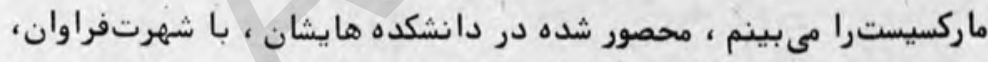

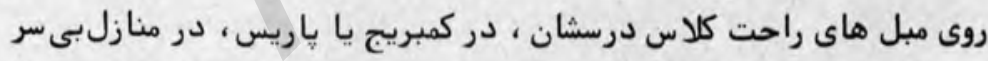

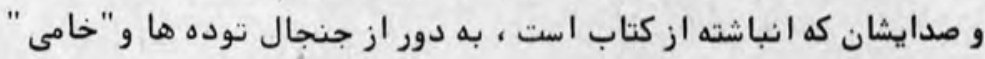

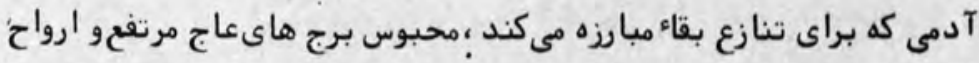

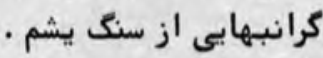
حه مى شد اكر يس از حندى عصر ديكرى آغاز و در آن ، ماركسيسم

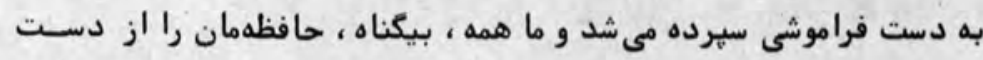

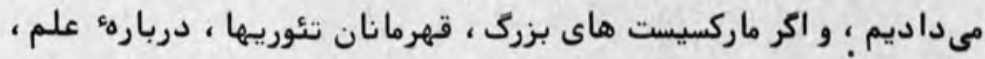

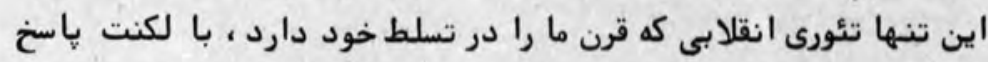

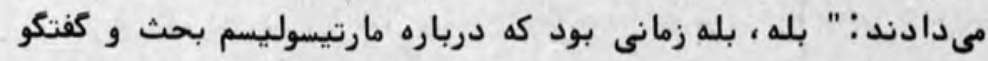

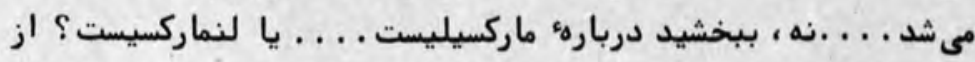


ملاقات د, ....

آن زمان مدت زيادى سيرى شده است . ديكر جه كسى يادش مى آيد ؟مــا مىكوييد:

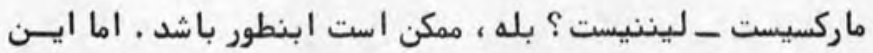

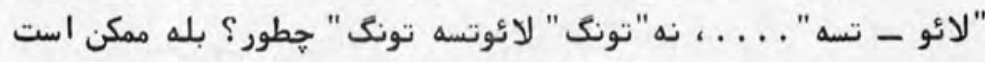

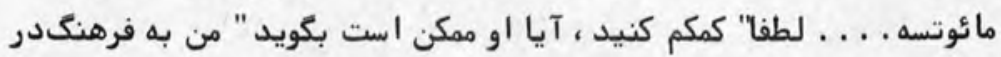

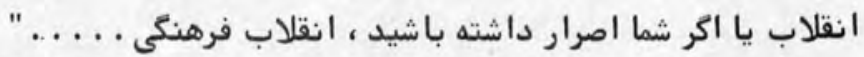

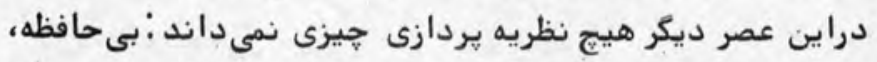

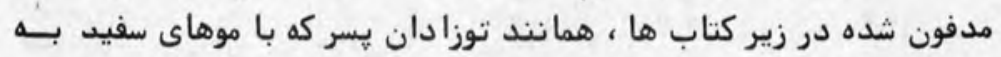

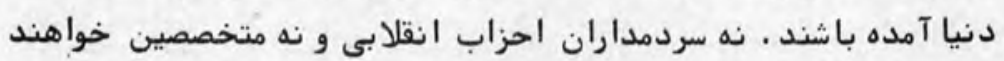

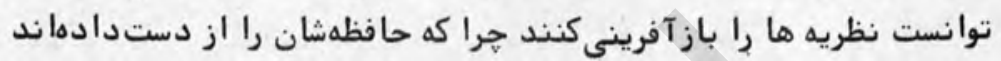
و مفاهيم متحجر شدهاند . توان. صحنه عوض مى شود . استاد مرا براى صرف نـهار به به رستــوران

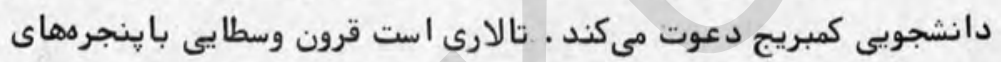

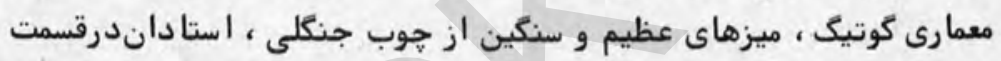

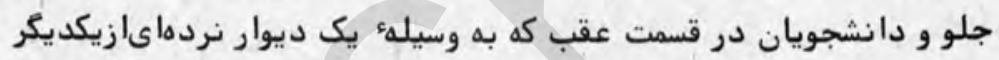

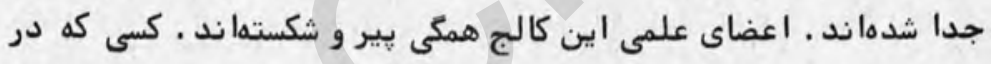

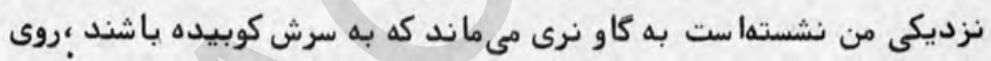

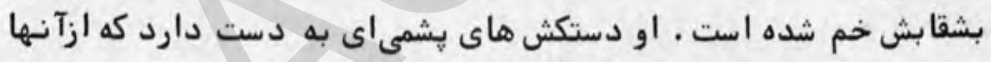

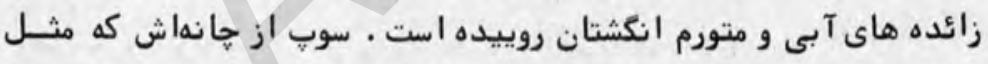

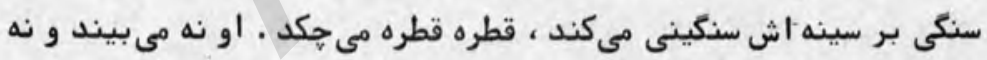

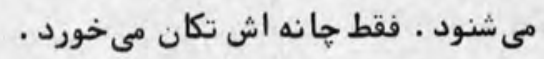

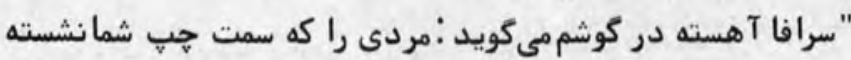

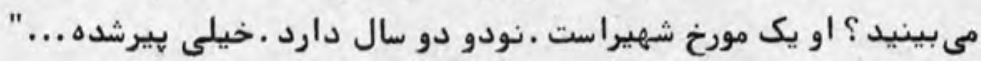

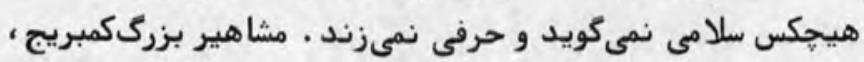

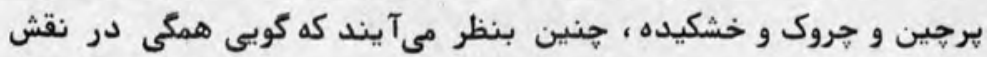

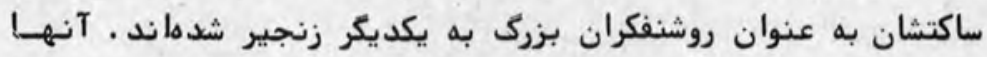

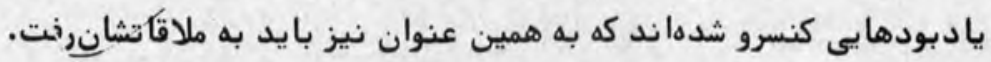

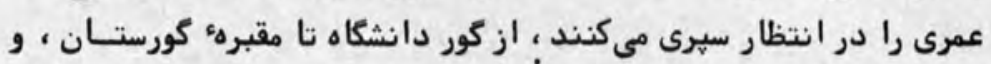


اكاه از حنين افتخارى ازلى وابدى . نكاهشان به من حنان كنجكاوانها ست

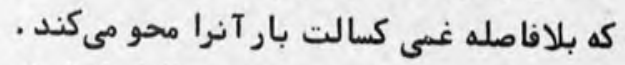

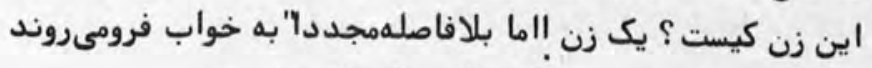

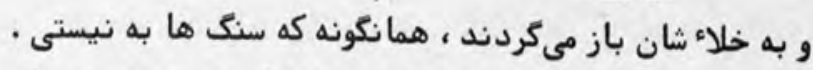

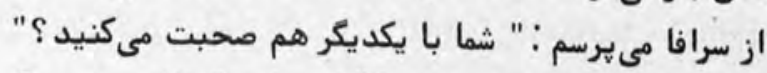

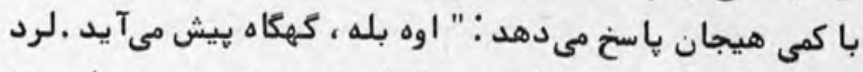

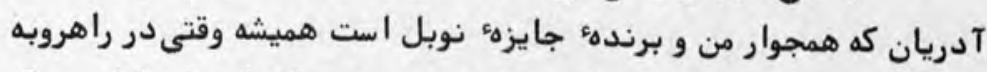

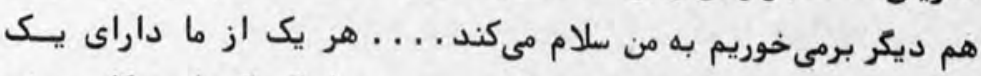

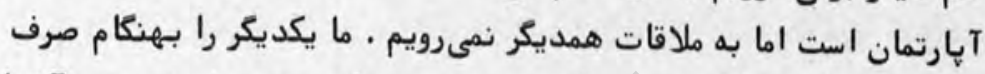

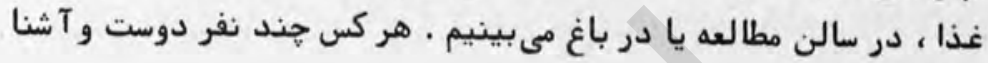

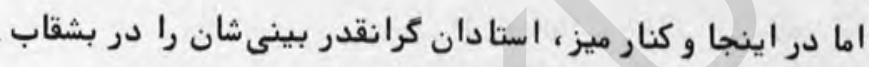

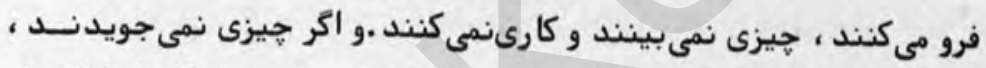

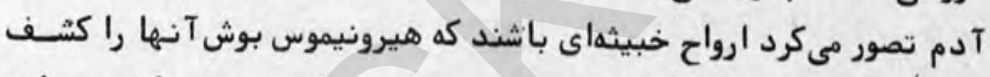

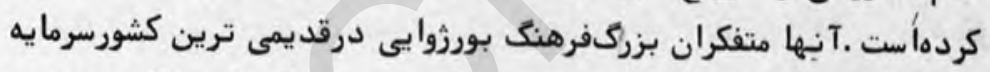

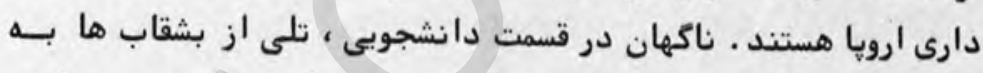

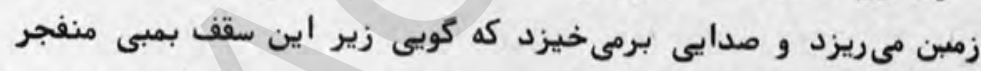

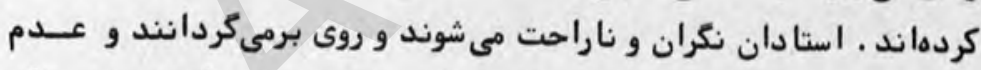

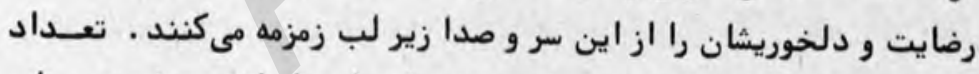

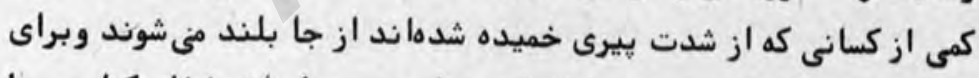

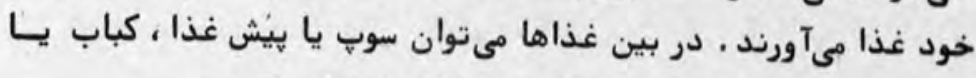

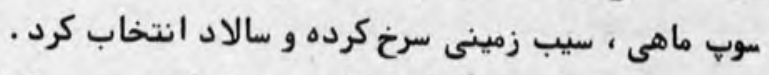

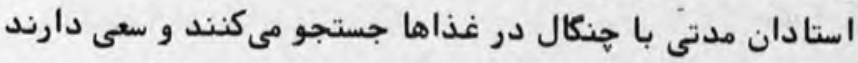

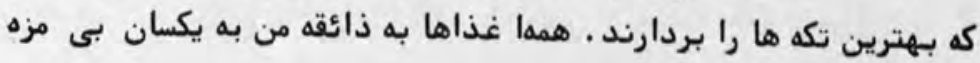

اين تنها ييرو سرافا نيست كه به من مىكويد غذاى استادان بههتر

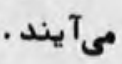

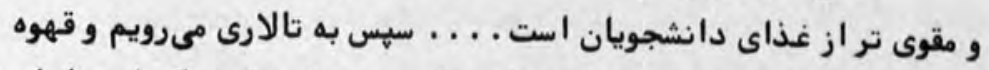

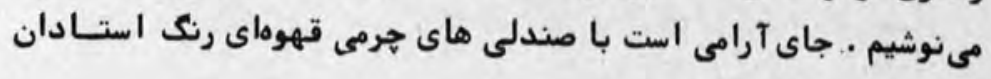


بسياريير روى روزنامه ها يشان به خواب رفتهاند . ما روى كانايه مىنتشينيم. استادان از خواب موميايى وار خود بيدار مىشوند و با نكاهى بـهت رده روزي روناي

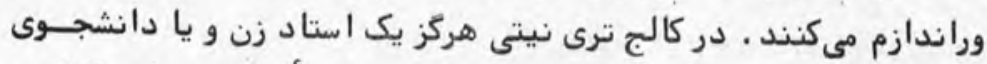

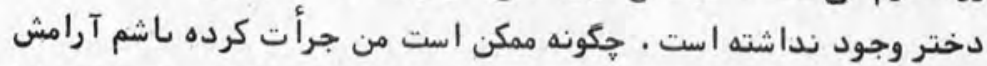
آنها را بر هم بزنم ا كمى عصبى مى شوم . احساس مى كنم بسيار جوانم اما

$$
\text { در عين حال مرده . كودكى مرده. }
$$

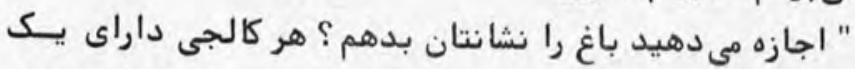

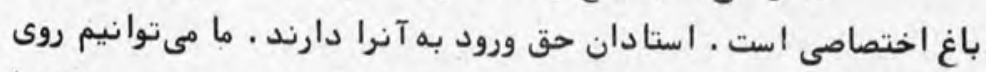

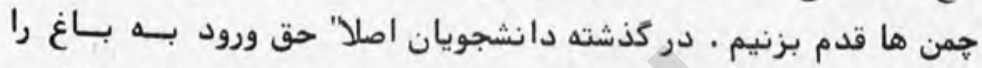
نداشتند . اخيرا" به آنها اجازه داده شده كه فقط صبح زود وارد باغ شوند

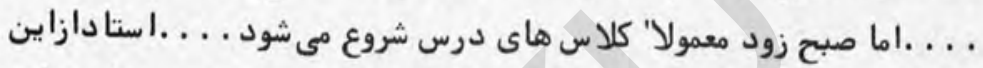
شُوخى لبخندى بر لب مى آورد ، كويى از اينكه جوان ها هنوز نتوانستها ند

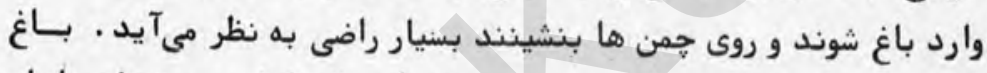

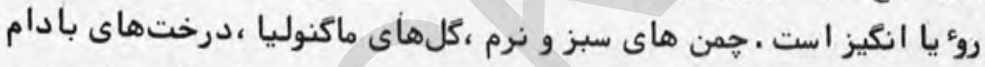

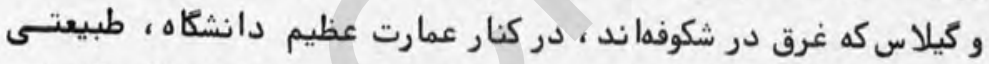

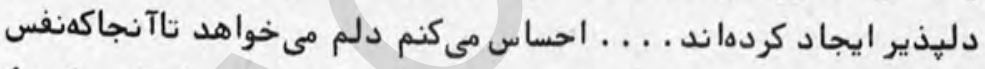

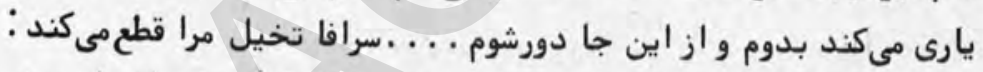

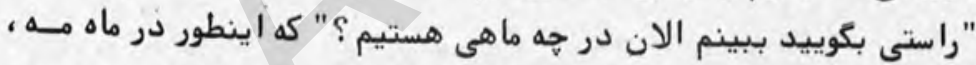

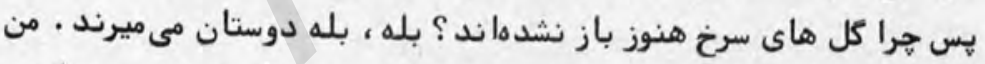

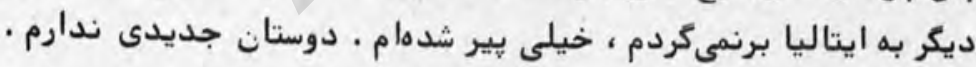

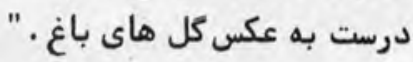
كرامشى در دور دست ها است . Tيا هركز حنين كسى وجودداشته

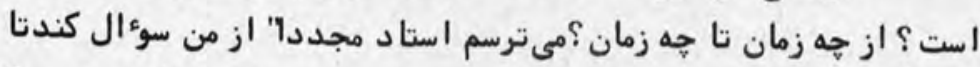

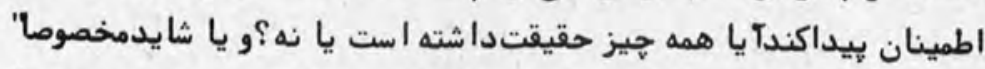
حنين مىكند؟ وهم و خيال حنان بيهوده است كه با بزركترين تزويـرها

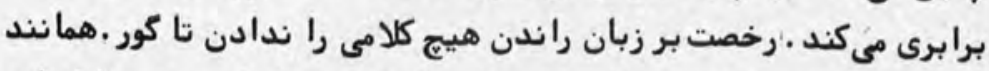

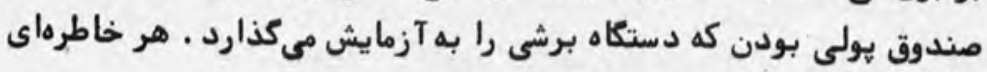


نوره8

ازكرامشى رابا خود به دنيايى ديكر بردن . به دور او، ، أ زمانى كه آدم

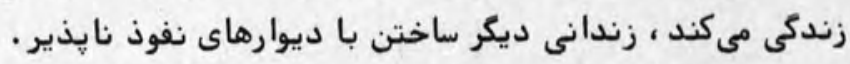

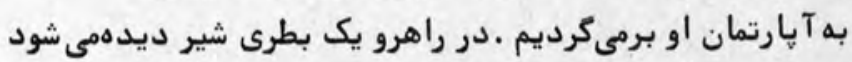

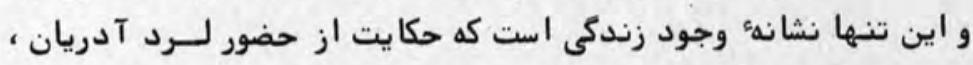

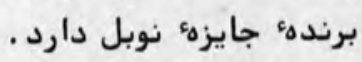

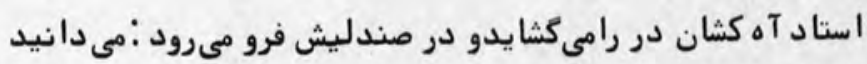

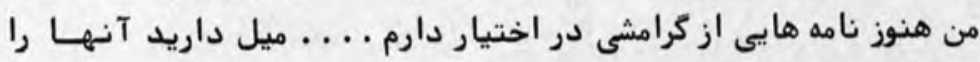

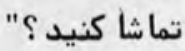

" البته ، خيلى هم خوشحال مى شوم ... . . قبلا" دلم مىخواست .

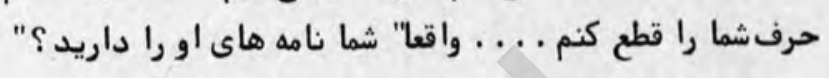

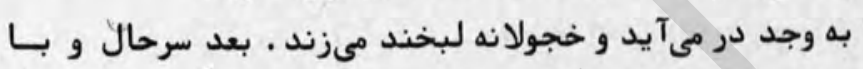

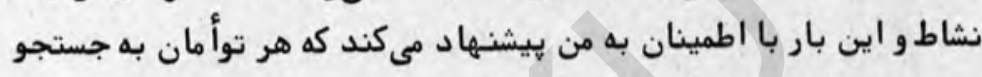

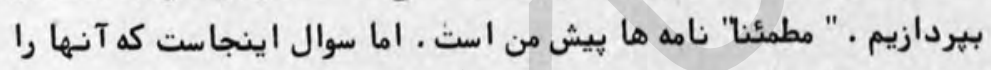

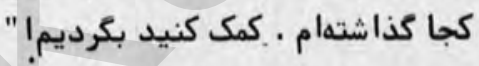

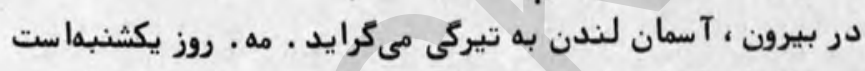

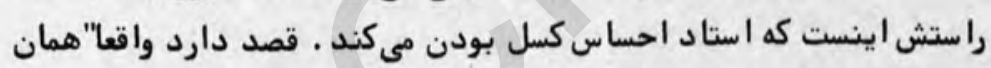

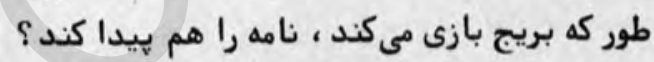

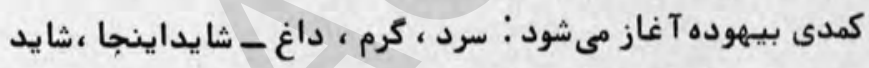

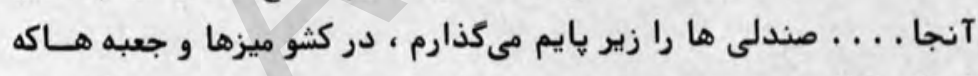

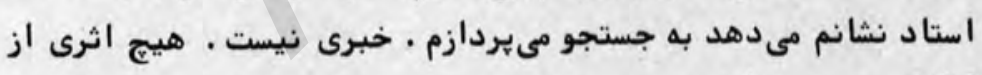

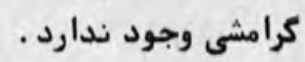

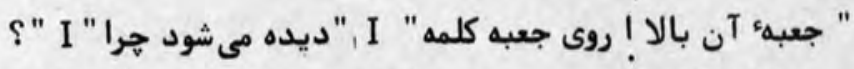

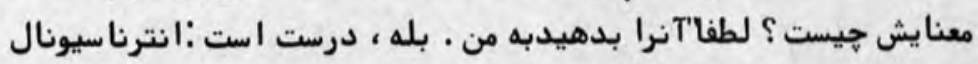

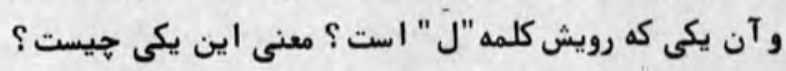

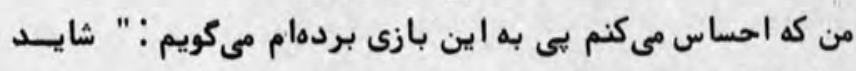

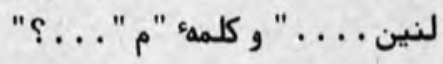

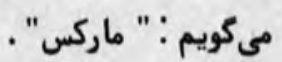

او در اين جعبههانخستين انتشارات نادر نوشته هاى سيـاسى ، مارك 
كتاب هاى كوجك ، بيانيه ها و نسخه هاى با ارزشى را براى انستيتو تاريخ

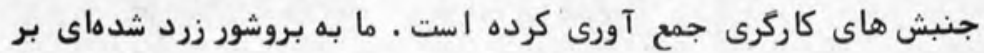

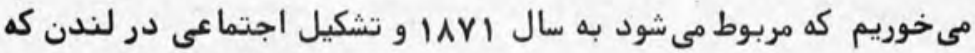

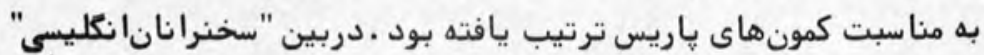

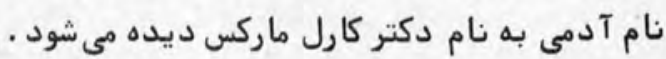

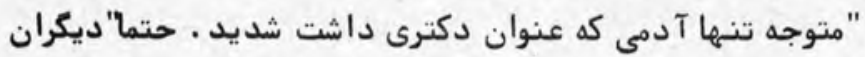

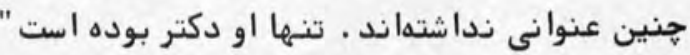

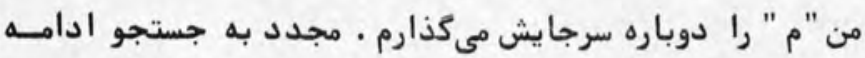

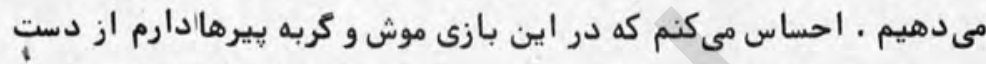

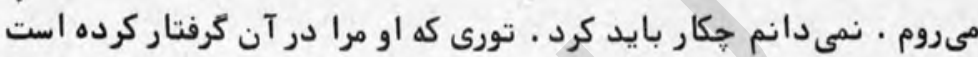

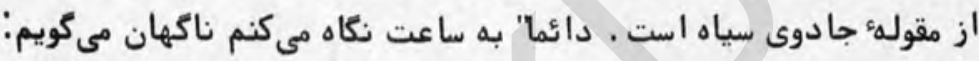

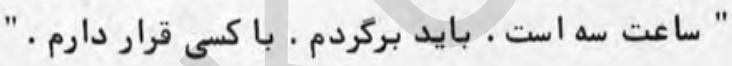

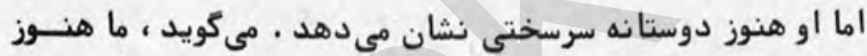

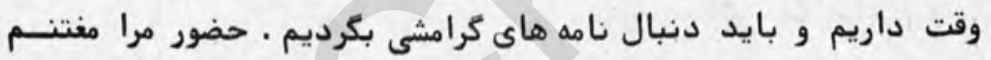

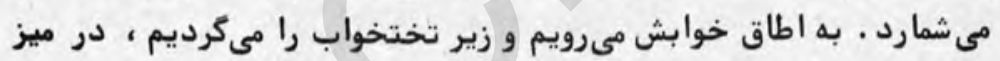

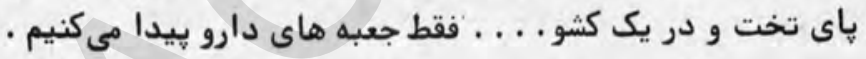

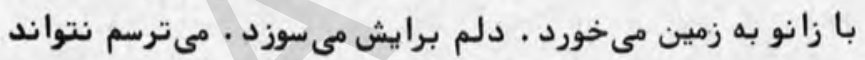

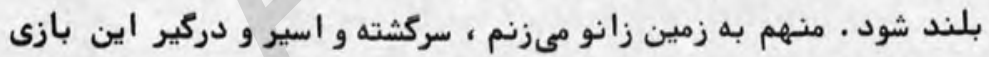

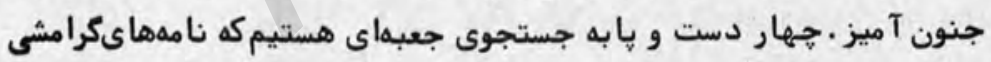
در آنست با.اطمينان خاطر مىكويد : " بالاخره يك روز يَيدايش مىكنـم.

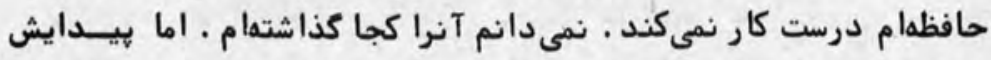

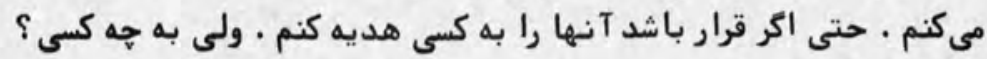

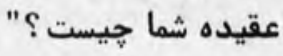

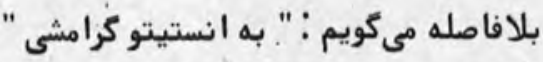

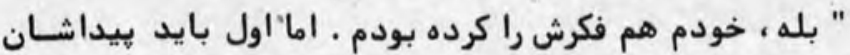

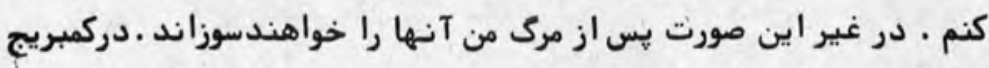

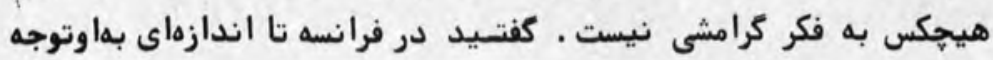




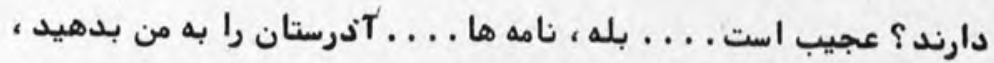

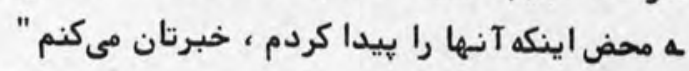

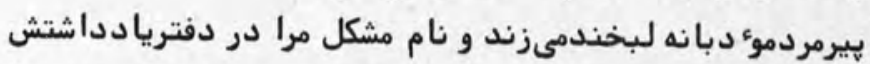

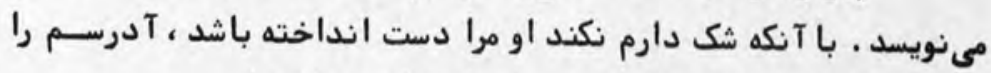

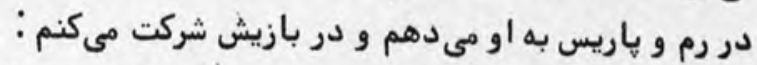

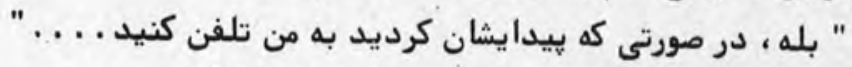

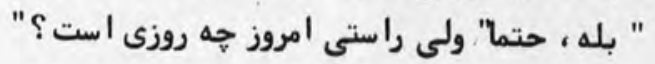

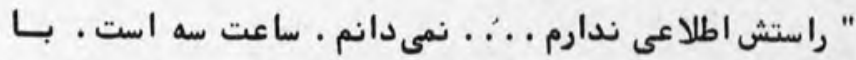

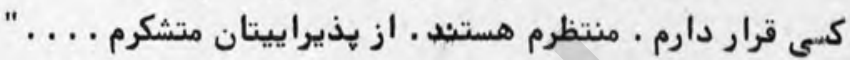

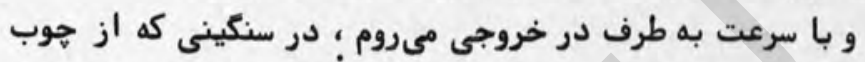

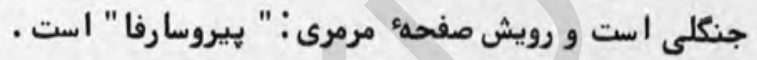
جنين بنظرم مى آيد كه اين نه كرامشى بلكه اوست كه از از سي وينج سال بيش به اين طرف مفقود شده است.

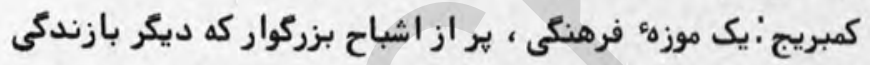

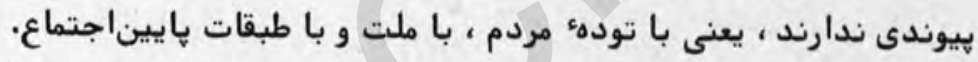

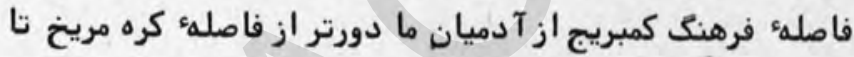

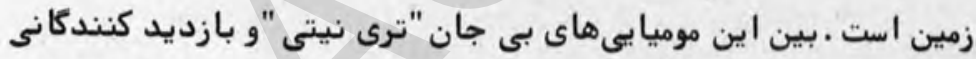

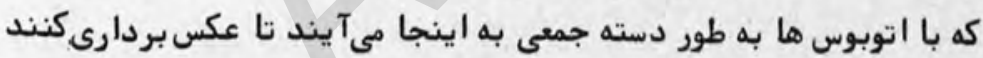

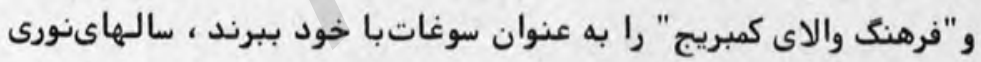

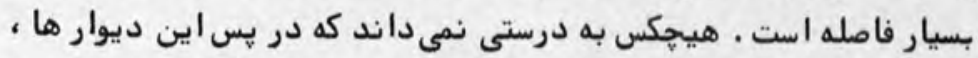

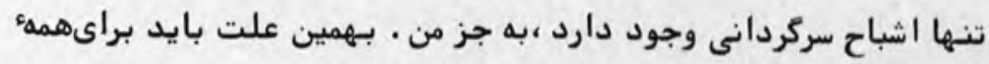

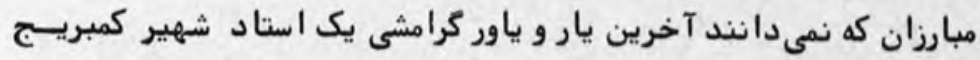

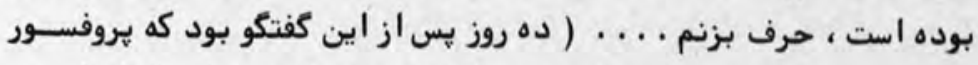

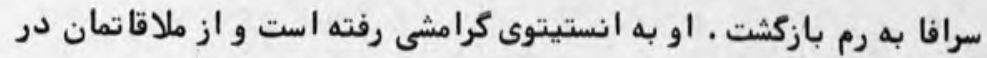

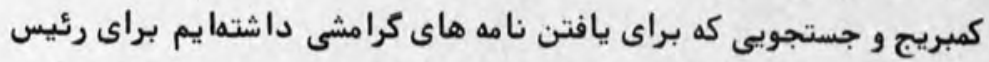

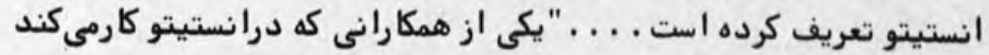

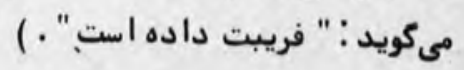

ترجمهء : هوشنك طاهرى 


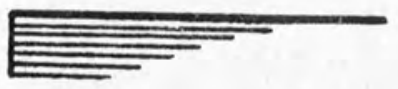

ماقات سفير نبطر كبير باشاه سلطان حسين

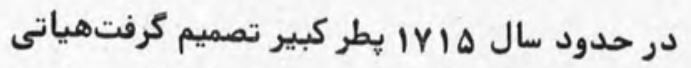

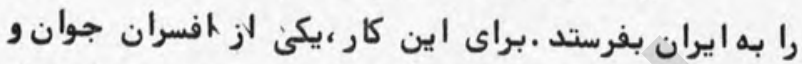

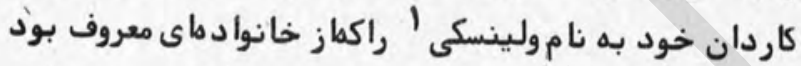

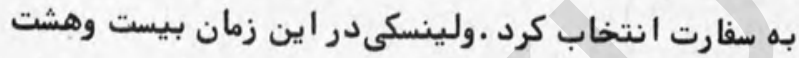

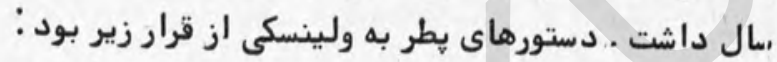

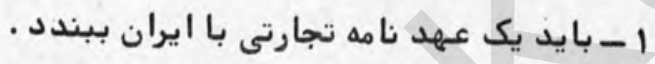

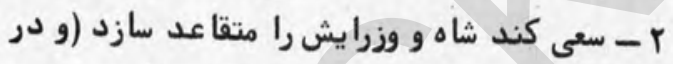

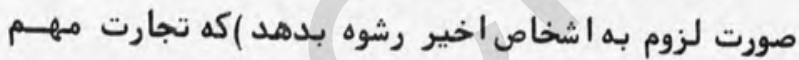

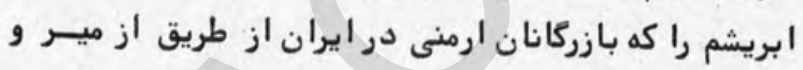

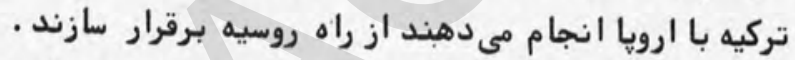

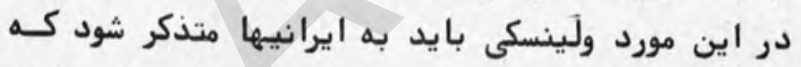

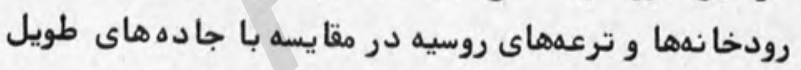

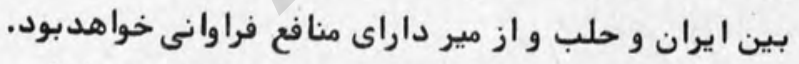

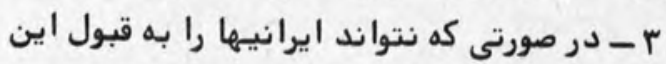

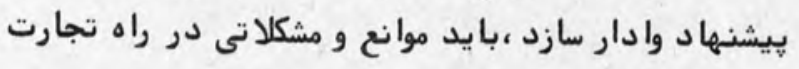

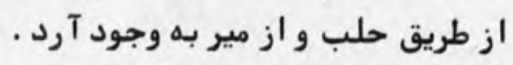

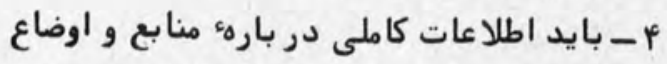

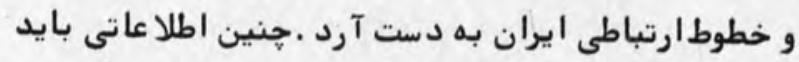

Valinsky اين نام به صورت . Volinsky - 
دوره:

شامل جزئياتوودخانههائى باشد كمبه درياى خرزمى ريزند،

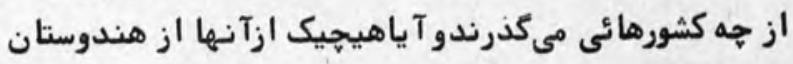

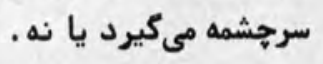

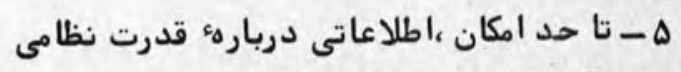

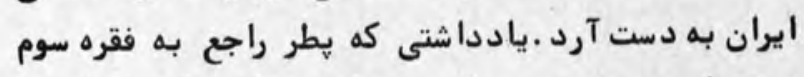

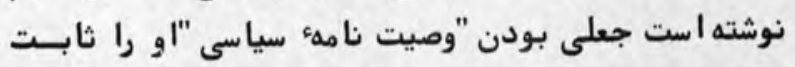

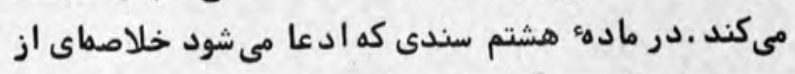

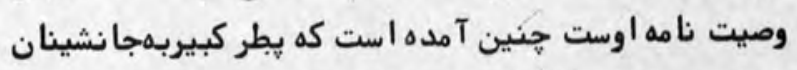

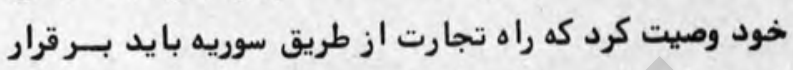

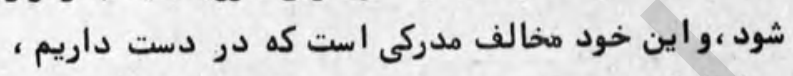

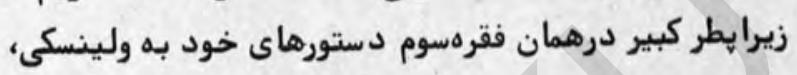

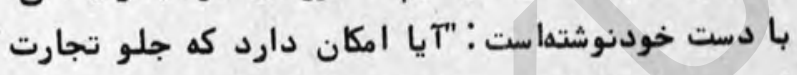

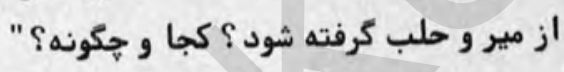

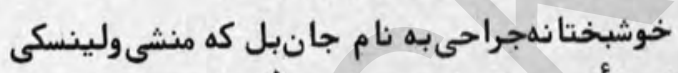

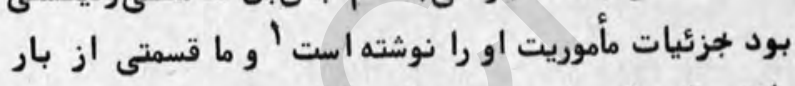

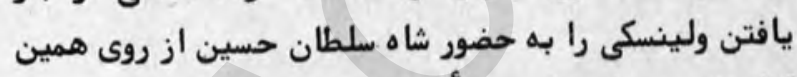

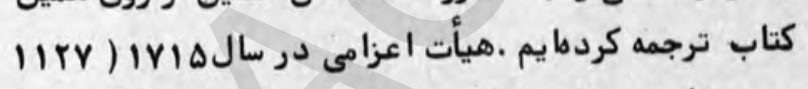

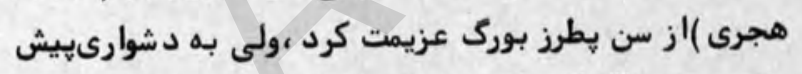

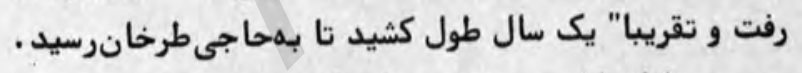

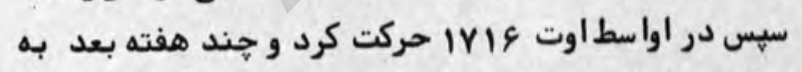

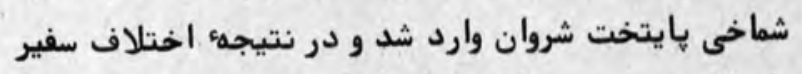
با حاكم دربارهء مقدار بولى بهى ولينسكى مى بايستى بكيرديك

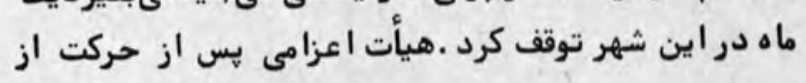
شماخى از طريق تبريز و ميانه و زنجان و مم (در اينجا

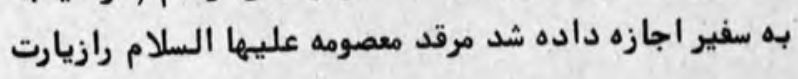

1- John Bell,Travels fromSt. Petersburg in Russia to DiverselParts of Asia, London, 1764. 


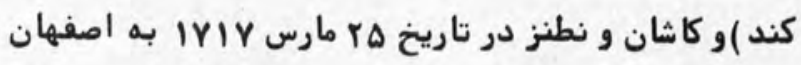

دولت ايران از ولينسكى و همراهانش به خوبى

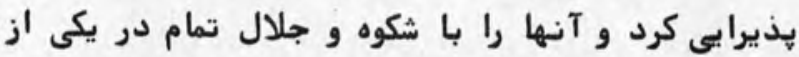

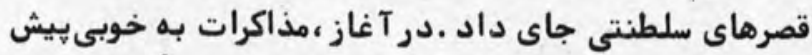

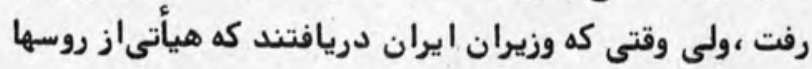

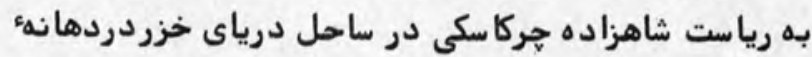

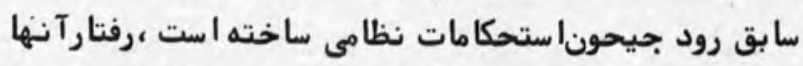

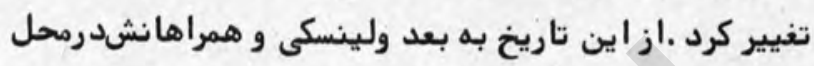

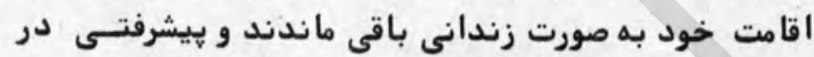

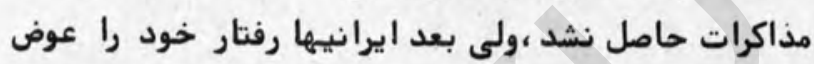

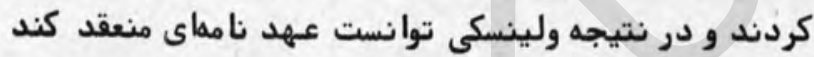

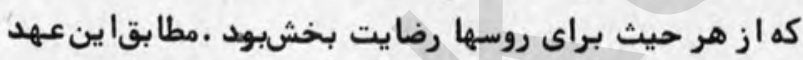

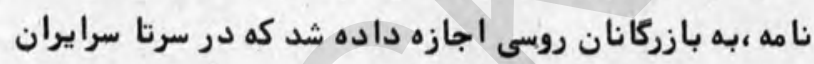

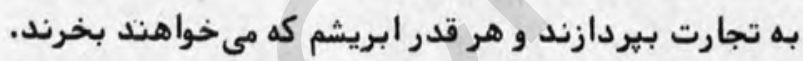

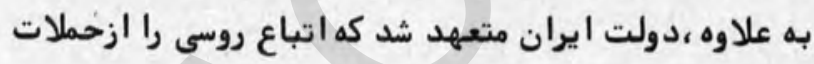

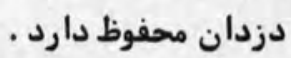

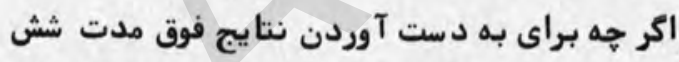

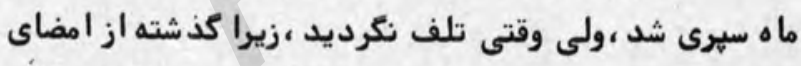

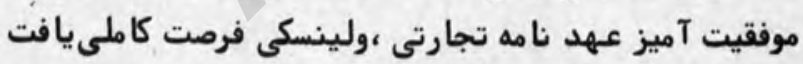

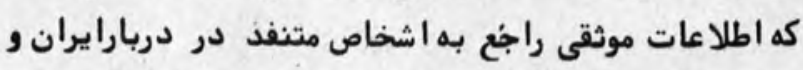

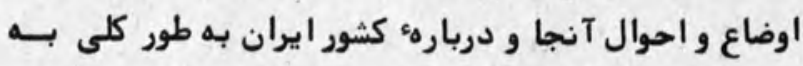

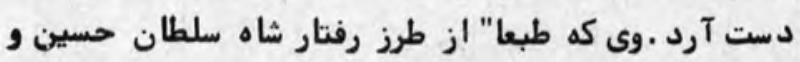

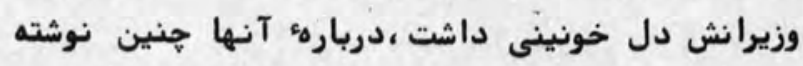

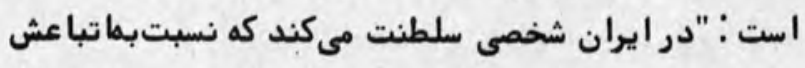

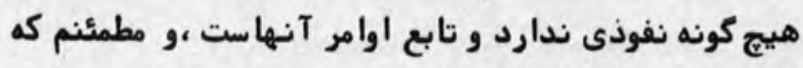

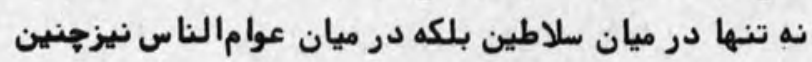

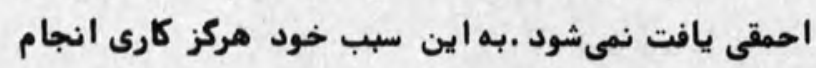


نمى دهد بلكه آن را به عهدهء اعتمادالدوله 'ا وا مىكذارد،

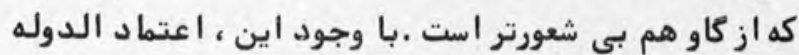
جنان محبوبيتى به دست آورده است كه هر كارى كه مي كند و هر حرفى كه مىزند مورد قبول شاه واقع مى شود . " سيس ولينسكى يیشبينى منقرض خواهد شد، مكر آنكه شحص لايق و قابلى بر تخت بنشيند .وى اظهار تما يل كرد كه براى جلوكيرى از حملات شورشيان افغانى ،ايالاتا يرانى واقعدر مجاورت درياىخزر به روسيه ملحق شود .اوضاع ايران حنان آشفته و يريشان و

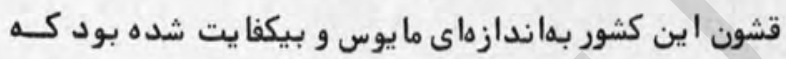

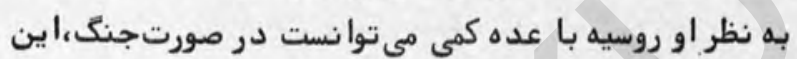

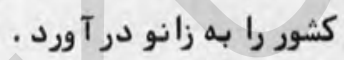

جان بل ،قبل از بحرانى كه يیيش از انعقاد عهده-

ا ـ بايد در نظر داشت كه اعتماد الدوله لقبـى

بود كه در زمان صفويه مترادف با نخست وزير در زمانمابه كار مىرفت .در آن روزكار ،فتحعلى خان داغستانى ايسـن منصب را داشت . بعدهابهسبب نفوذى كه به هم رسا نيد، مورد حسادت قرار كرفت و به تحريك دشمنان و به دستور شاه سلطان حسين كور شد .رجوع شود به اسماعيل دولتشاهى ؛ "عزلو محاكمهء وزير شاه سلطان حسين ، "مجلهسخن ،دورهء

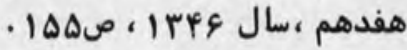
ا ـ اكر جه مطالب ولينسكى در باره شاهسلطانـحسين درست اسبت ،ولى لياقت و كاردانى فتحعلى خان داغستانى حنا نكه بايد و شا يد توصيف نشده است . بدون ترديد ،بدرفتارى او را با ولينسكى نبايد از نظر دورداشت. رجوع شود به لارنس لاكهارت ،انقراضسلسلهء صفويه ،ترجمه اسما عيل دولتشاهى ،بنكاه ترجممونشركتاب ، تهران ، I Ifff 
نامه ايران و روسيه روى داد ،دربارهء شاه سلطان حسيـن نظر مسا عدترى داشت ،ولى نوشته است كه "اين یادشاه از امور دنيوى اطلاعى ندارد وادارهكشور را بهزعهدهء وزيران خود محول مىكند و به آنها اعتماد و اطمينان كاملى دارد. آنها نيز به نوبهء خود او را متقاعد كردها ند كه يرداختن به

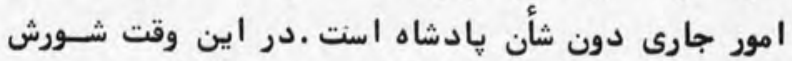

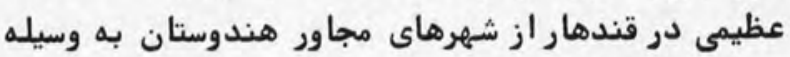
محمود ،رئيس مقتدر قبيلهاى كه از ضعف دولت ايـران استفاده كرد ،بر يا شده بود . "

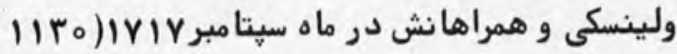

هجرى )از اصفهان عزيمت كردند و هدايايى از طرف شـاه براى يطر كبير بردند .اين هدايا شامل دوشير و يك فيل

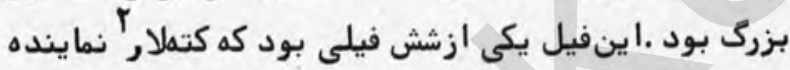

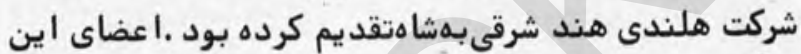
هيأت در بازكشت كرفنار طاعونى شدند كه در آنوقت شيوع داشت و يكى از آنها در قزوين به اين بيمارى در كذشت.بد بد

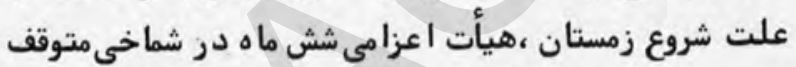
شد و بعد از حركت از اين شهر در ماه زوئن IVIA سفيـر و باقى هيأت كه بيست و دو نفر از آنها در ايران فوت شده بودند در اوايسل سال و يطرز بورك رسيدند .اكر جه يطر كبير در ابتدا از طـول

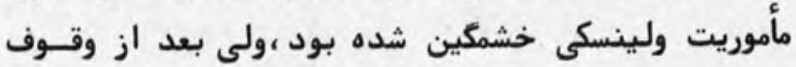

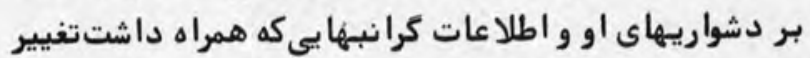
عقيده داد و براى قدر دانى از خدماتش دختر عم خود شاهزاده خانم ناريشكين را به عقد او در آورد و سيس براى

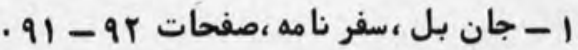

\section{2-Ketelar}


مراقبت در امور ايران ،ولينسكى را به حكومت حاجى طرخان

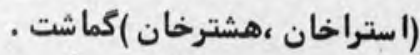

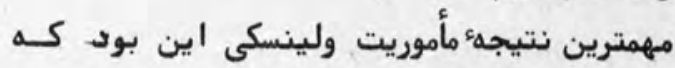

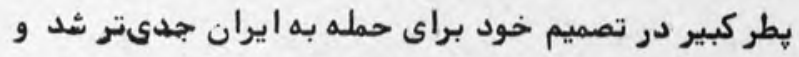

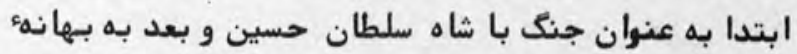

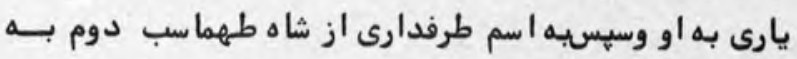

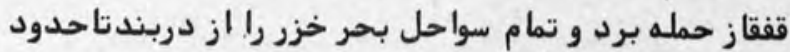

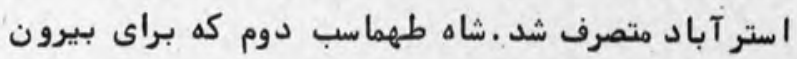

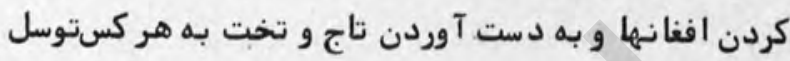

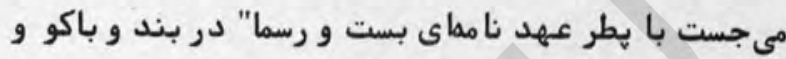

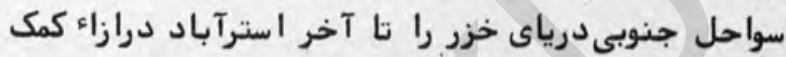

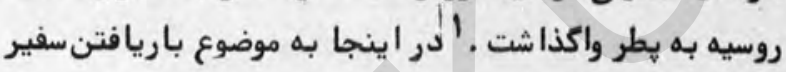

$$
\text { كزارش منشي سفير يردازيم . }
$$

يس از آنكه تشريفات معرفى سفير به حضور شاه مورد موافقت قرار

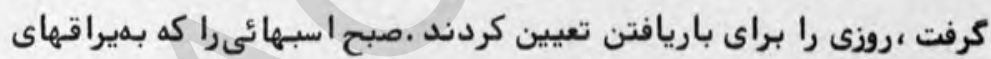

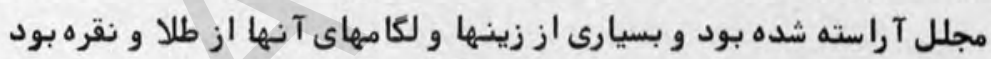

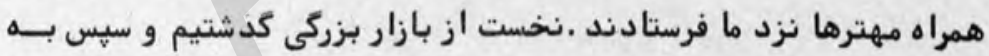

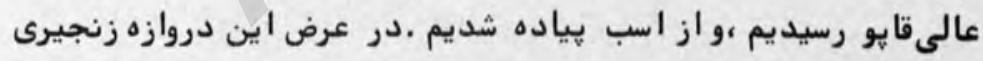

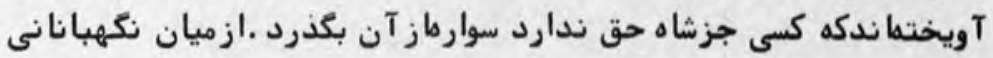

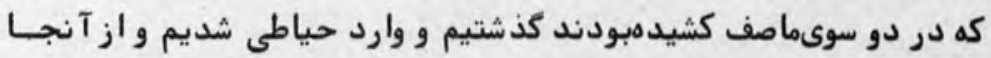

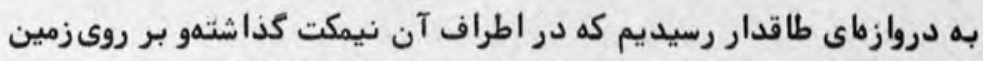

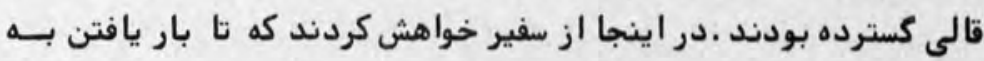

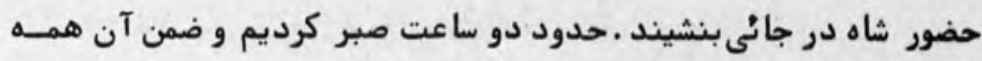

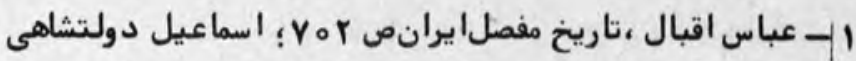

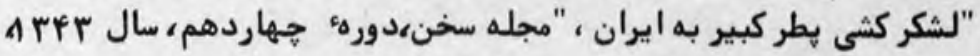




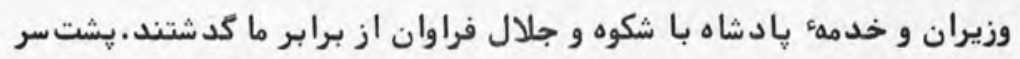

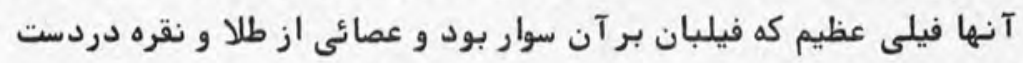

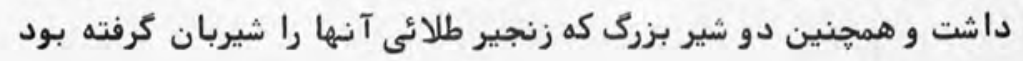

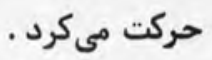

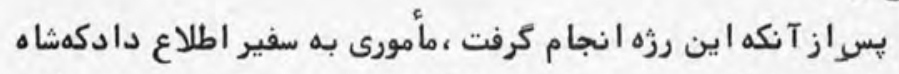

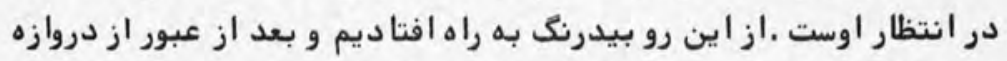

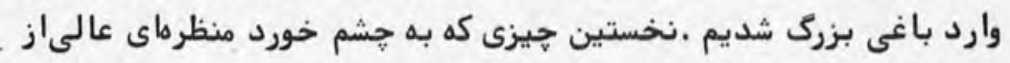

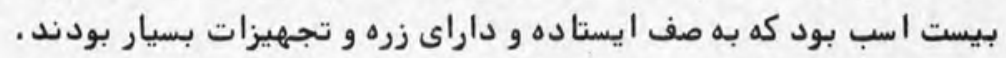

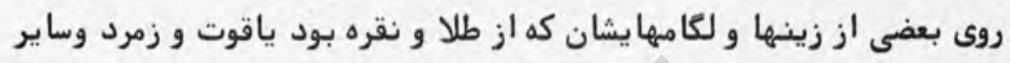

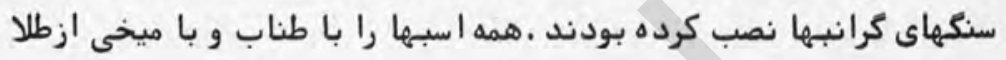

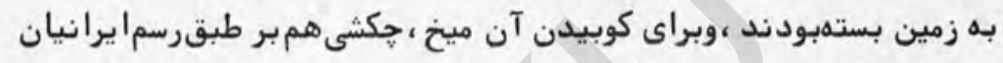

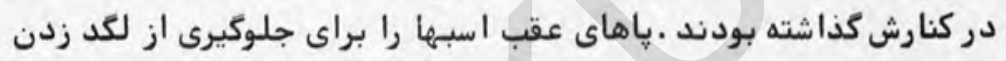

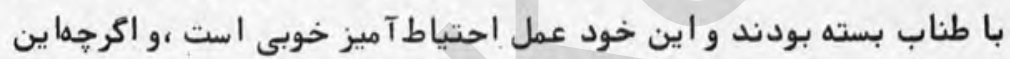

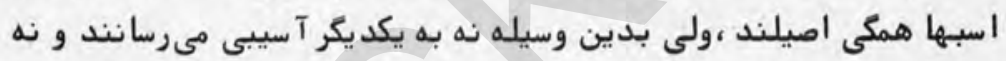

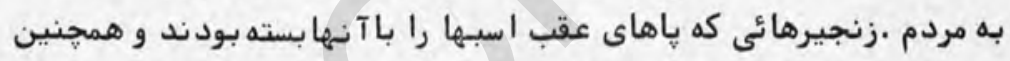

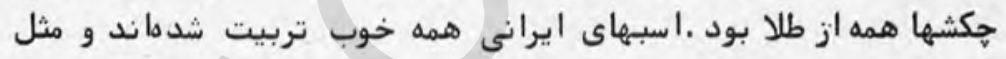

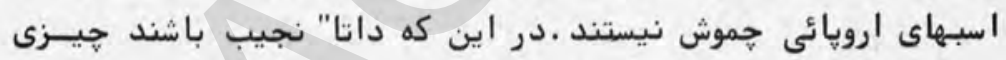

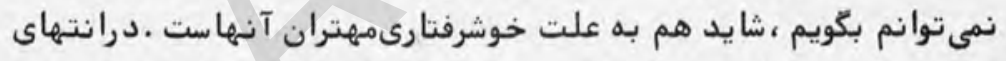

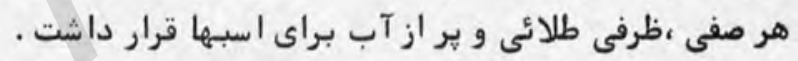

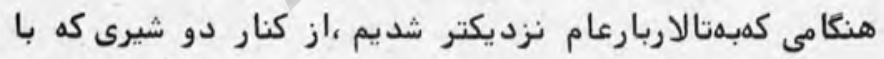

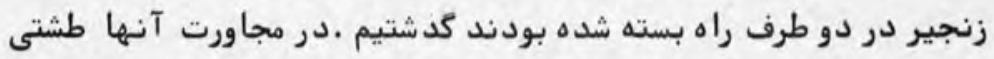

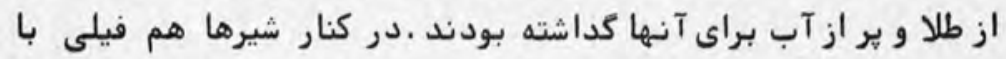

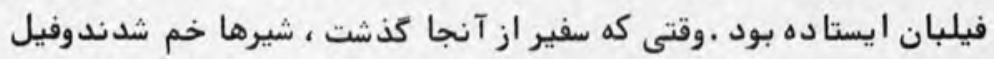

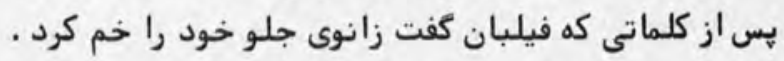

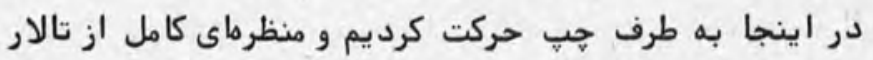

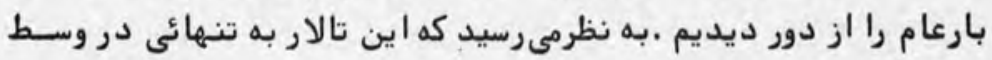

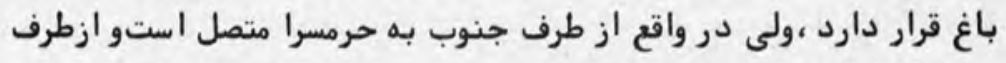

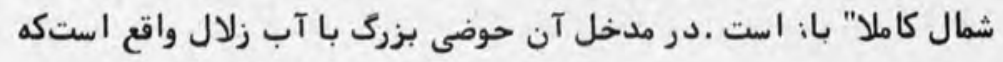


از آن به وسيلهء سه لوله ،آب فوران مىكند و بهحوضى كه ير از كل و يا سمن

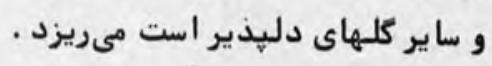

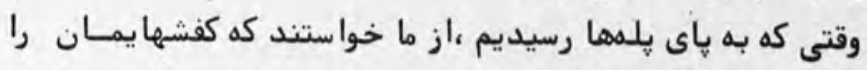

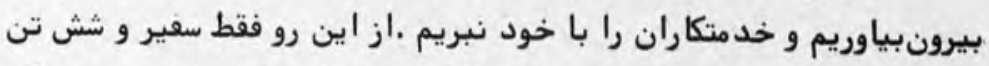

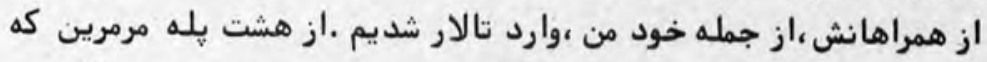

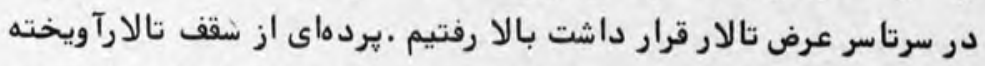

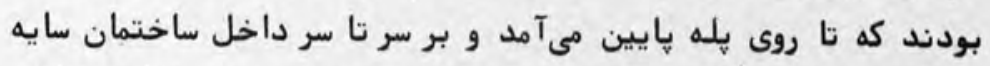

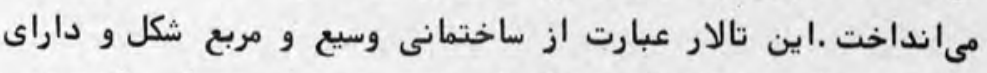

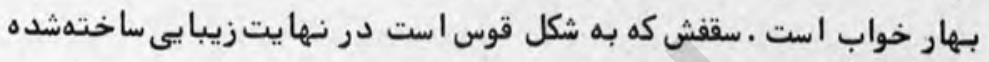

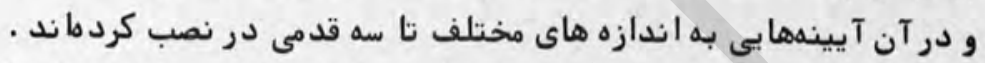

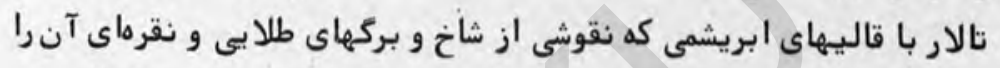

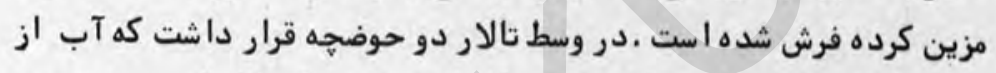

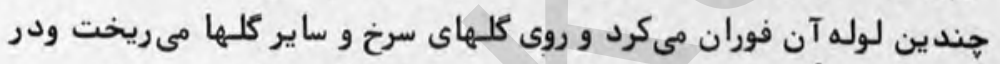

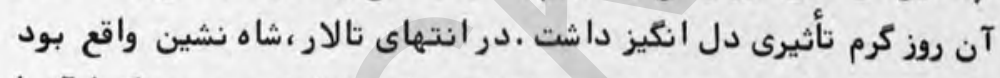

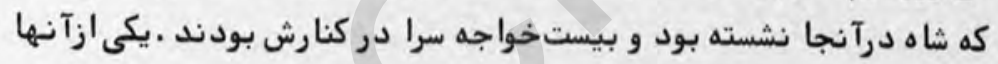

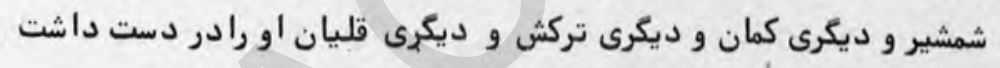

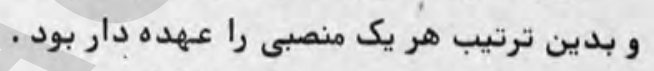

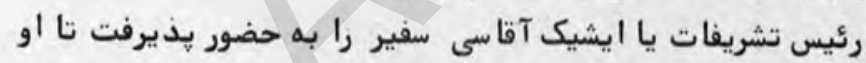

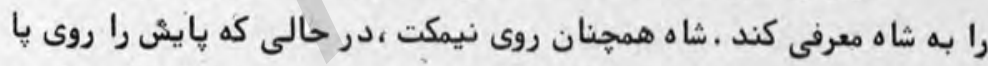

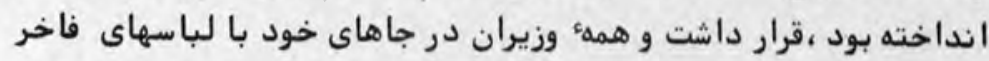

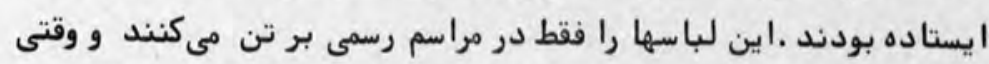

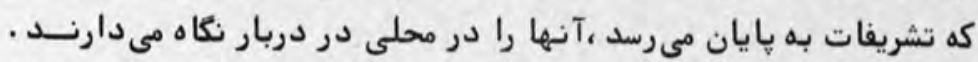

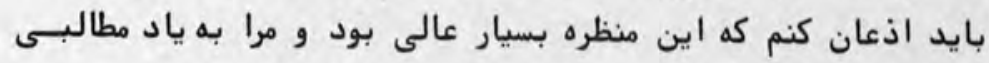

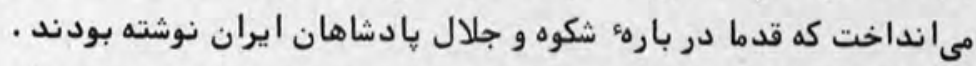

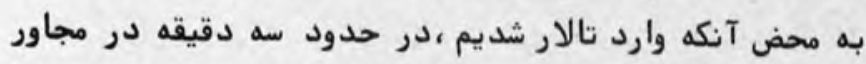

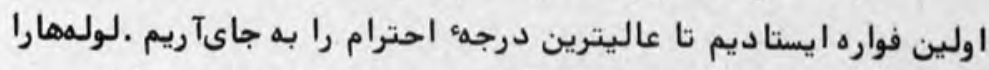

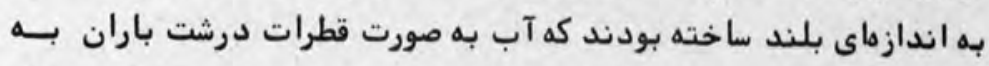

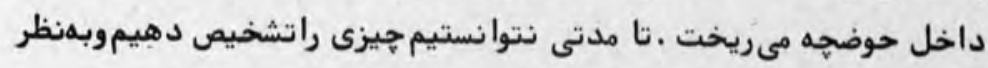


fis ملاقات

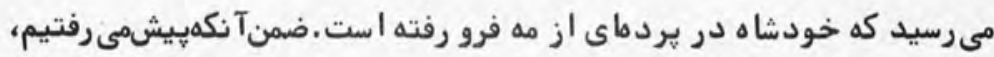

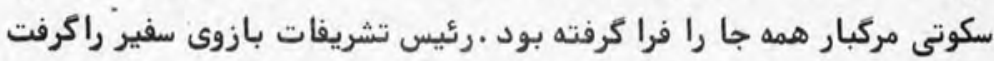

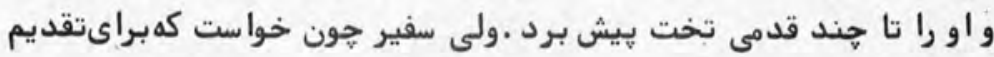

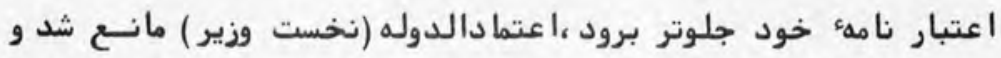

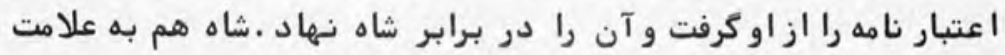

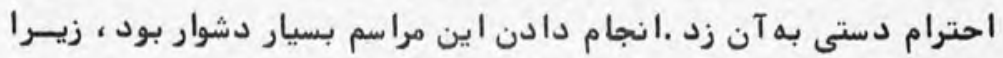

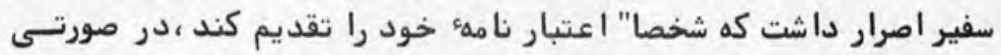

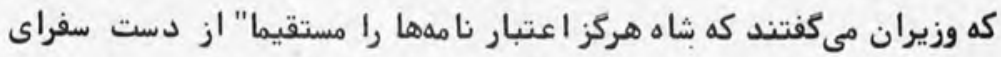

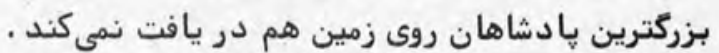

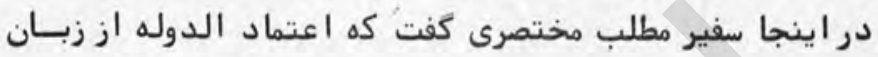

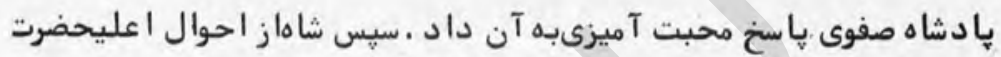

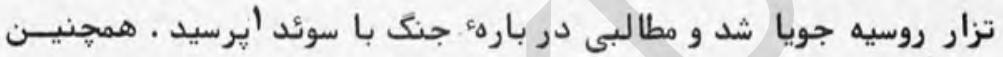

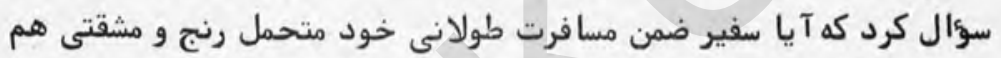

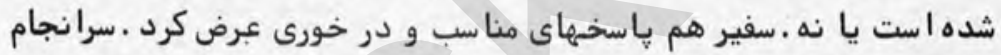

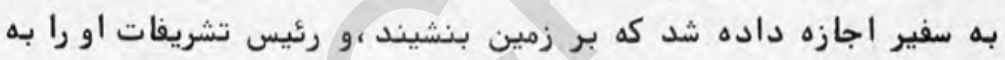

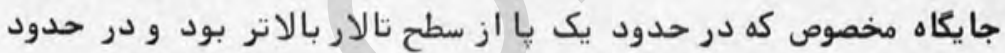

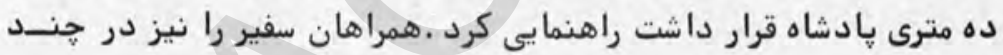

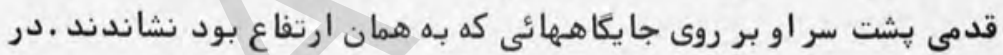

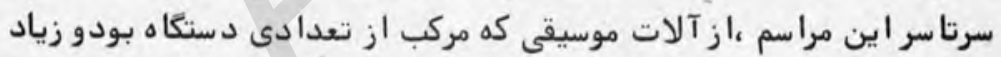

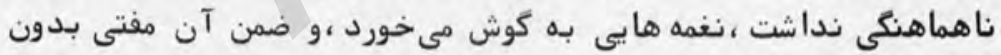

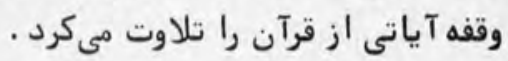

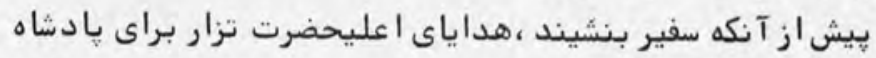

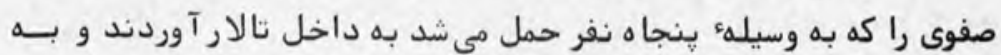

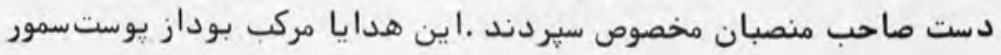

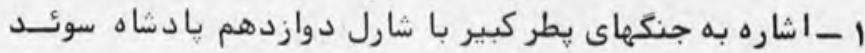

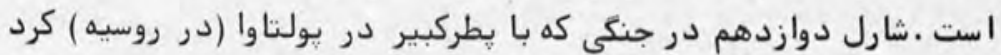

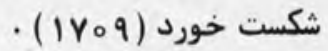




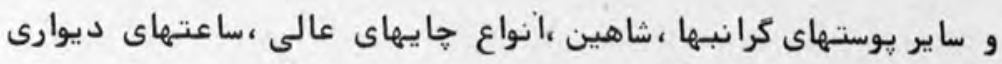

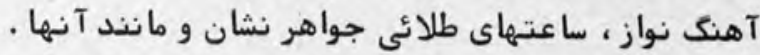

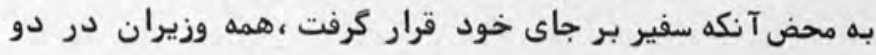

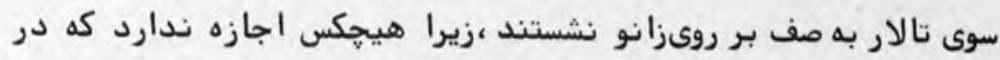

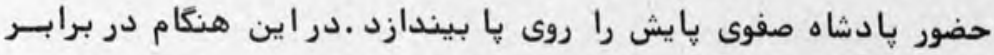

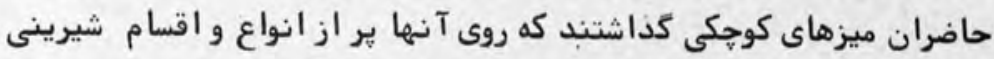
بود.در برابر سفير نيز قليانى از طلا كه در نظر ايرانيان به منزلـهـ

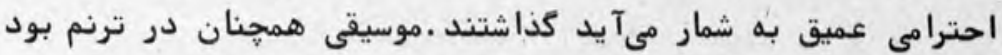

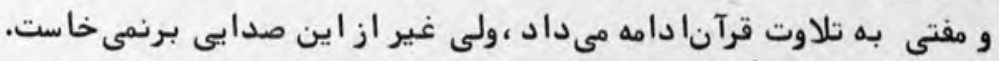

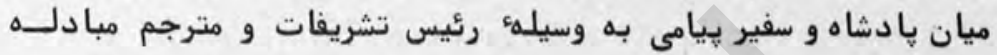

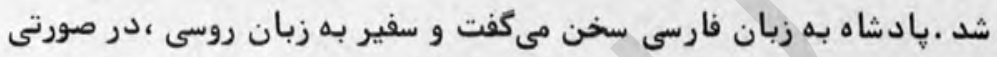

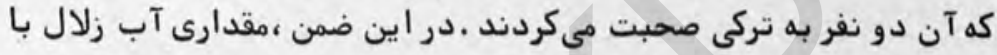

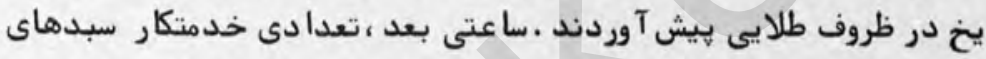

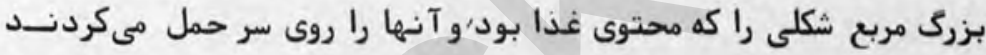

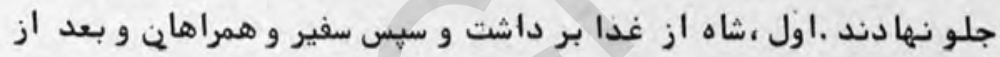

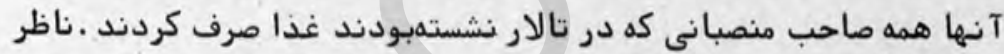

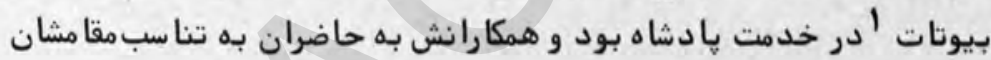

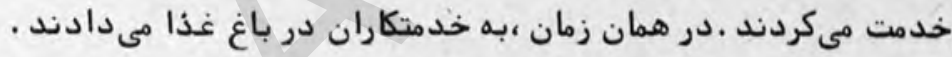

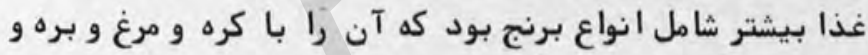

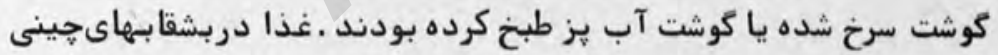

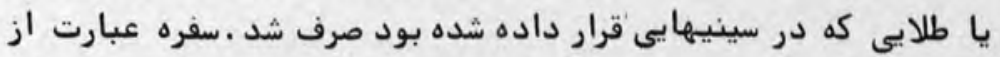

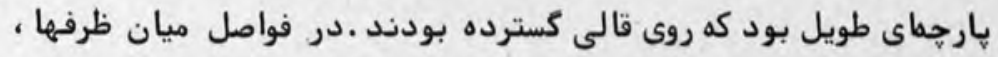

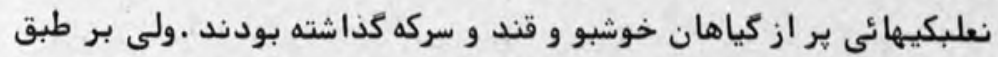
رسوم مملكت ، نه دستمالى در اختيار داشتيم و نه قاشق و حنكال و كاردى.

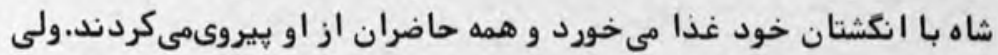

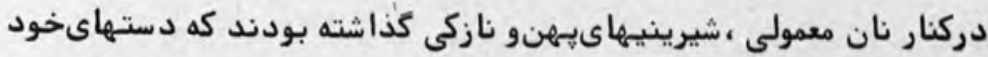

$$
\text { - إيشكار يا مباشر }
$$


ملاقات سفبر

را با آن هاك كرديم .اين شيرينيههارا از آرد سفيد مى سازند و ايرانيانكاهى

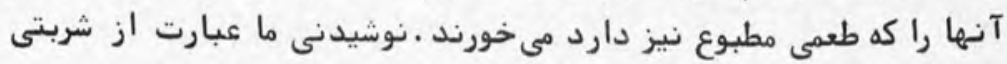

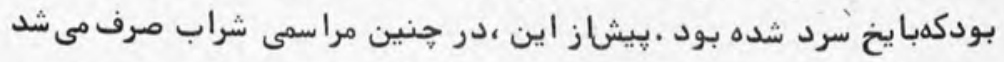

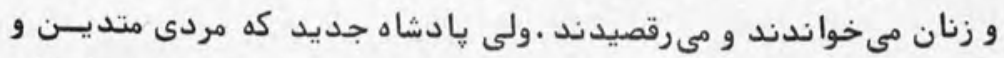

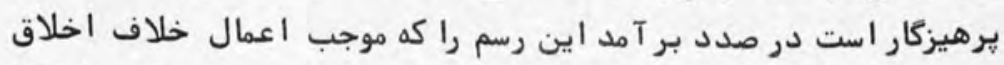

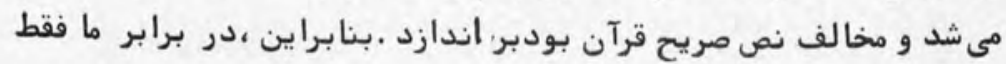

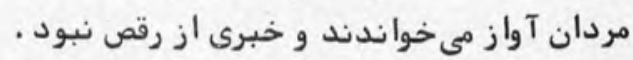

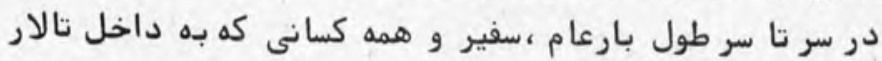

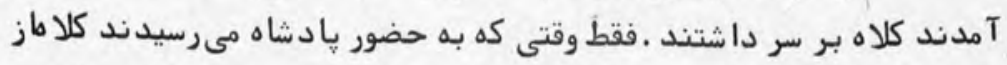

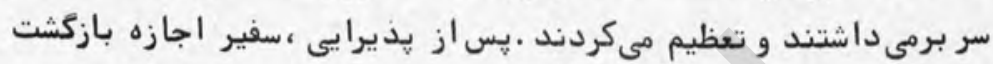

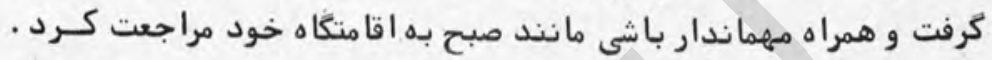

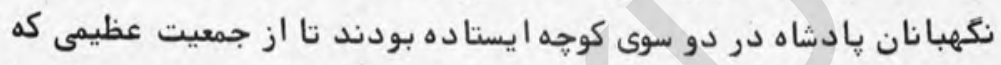

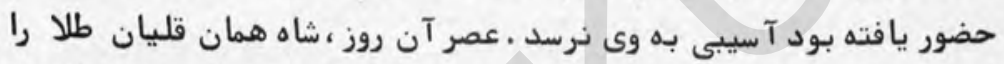

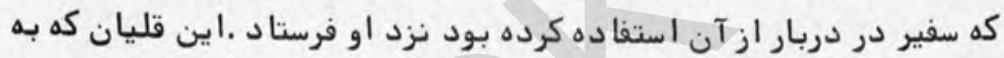

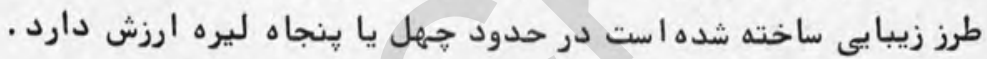

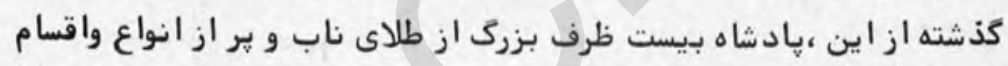

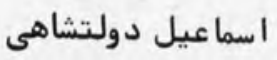
شيرينى نزد سفير فرستاد .

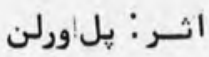

$$
\text { توانه خزان }
$$

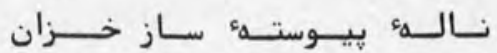

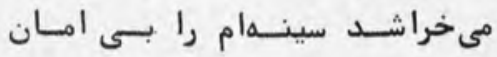

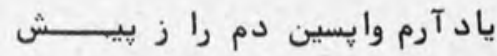

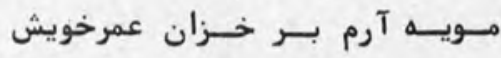$$
\text { اى دريغا هون بــرآيد بــاد مـرى }
$$

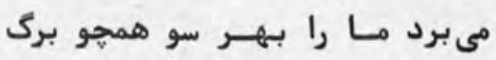

دروس: اول اسفند ماه

$$
\text { ترجمهء : حسينعلى ملاح. }
$$




\section{* تو كيب در زبان فارسى}

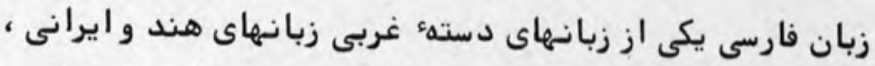

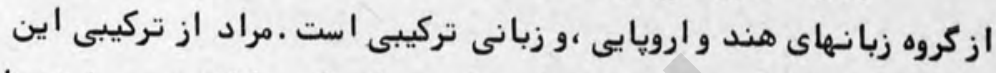

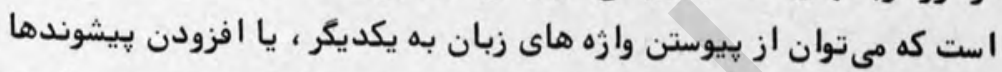

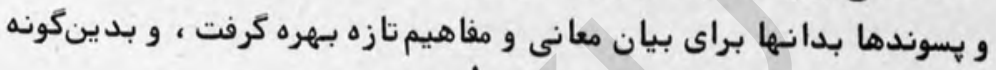

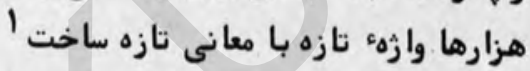

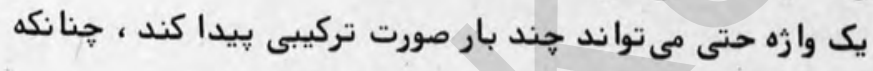

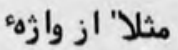

( ) خرد (عقل ) + مند (يسوندا تصاف و دارندكى ) وازوهء خردمند

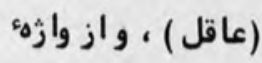

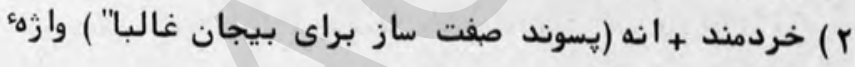

$$
\text { خردمندانه (سخن خردمندانه ) ، و از وارؤه }
$$

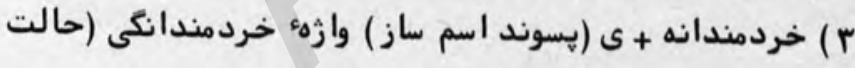

و وصف خردمندانه بودن ) بديد مى آيد .

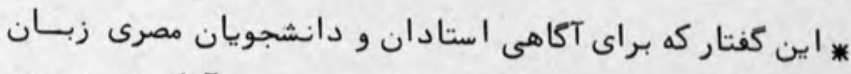

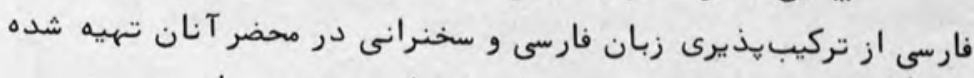

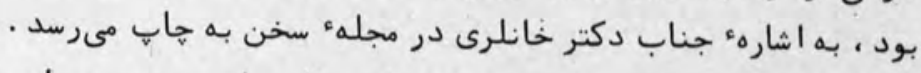

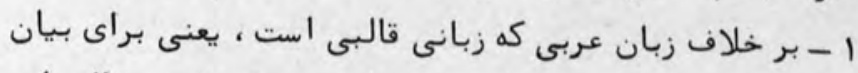

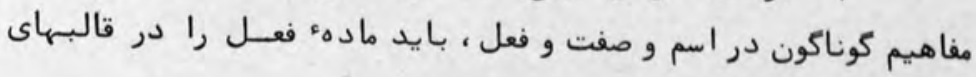
كوناكون مجرد يا مزيد بريزد . 


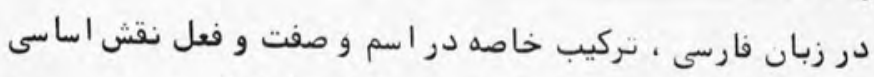

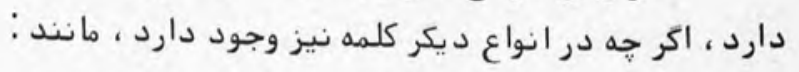

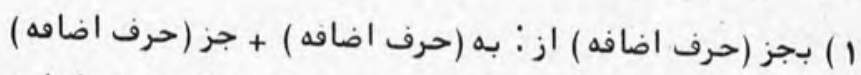

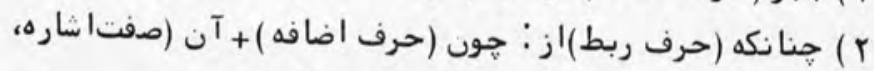

ضمير اشاره يا مبههم + كه موصول )

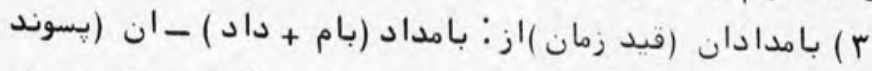

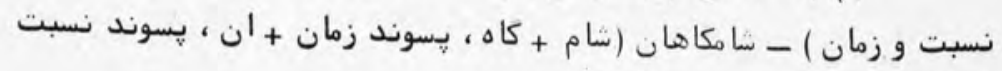

براى نمونه از جند وارّه زير تركيبها يى به دست دادهمىشود : و زمان)

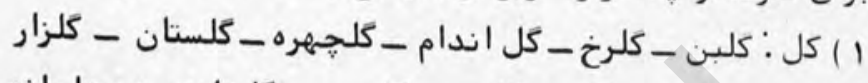

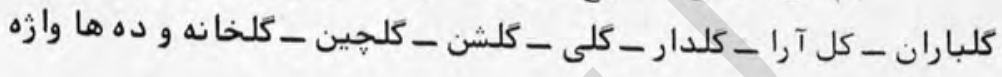

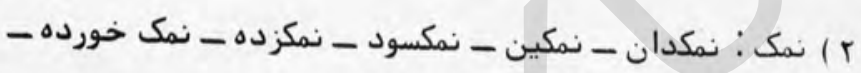

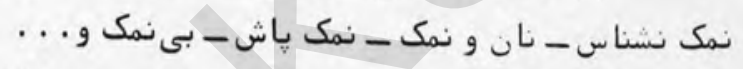

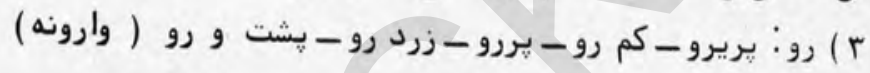
ديكر .

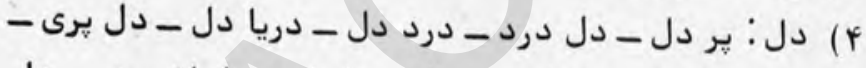

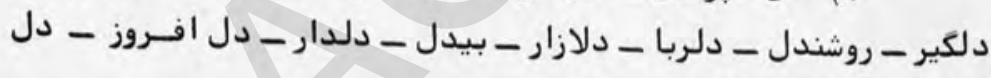

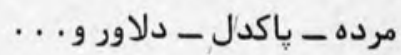

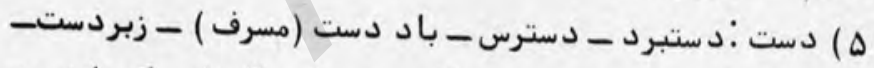

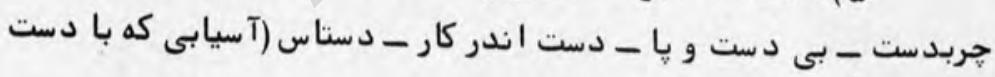

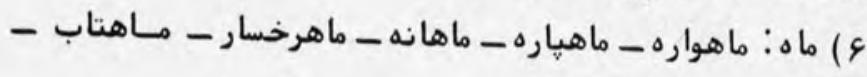

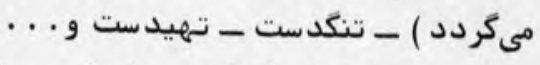

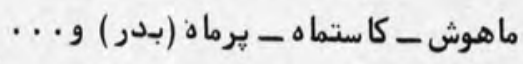

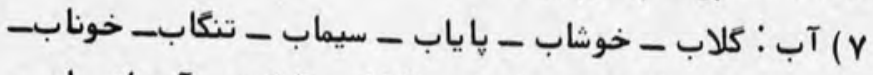

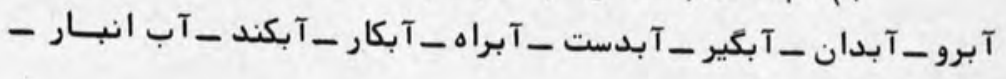

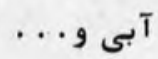




\section{تركيب در اسم و صفت}

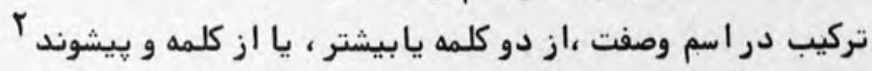

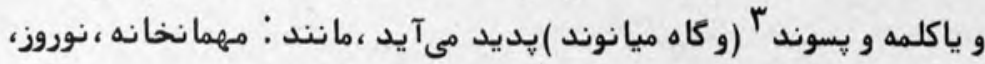

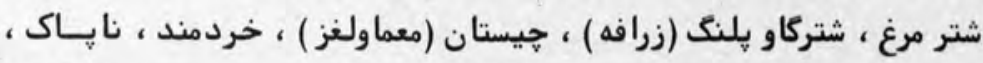

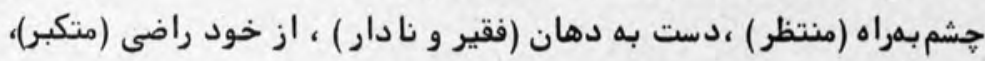

$$
\text { انواع تركيب در اسم }
$$$$
\text { تكا يو }
$$$$
\text { الف- }
$$

اسم مركب يا از دو وازوهء ساده (حداقل) يديد مى آيد ، مانند :

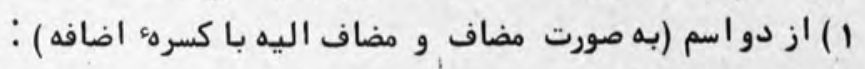

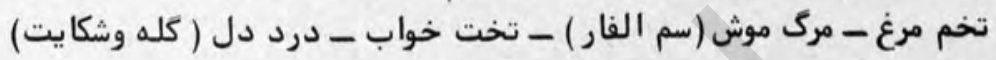

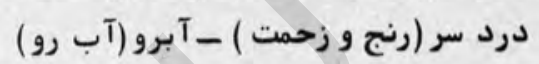

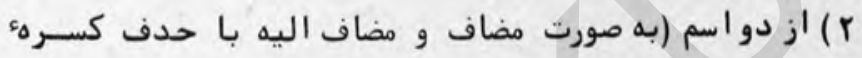

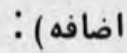

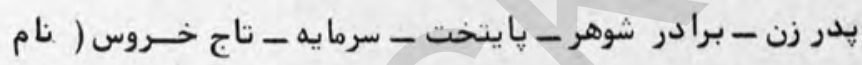

كلى است )

r از دو اسم (به صورت اضافهء مقلوب ) : كلخانه _ بارنامـهـ-

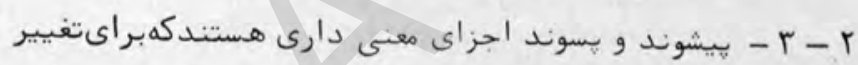

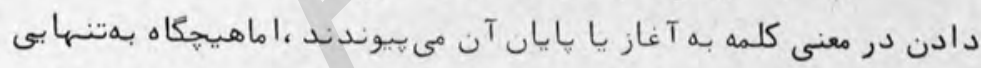

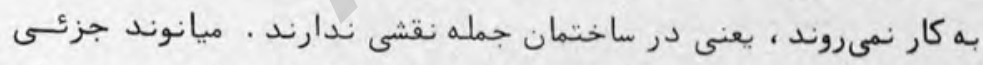

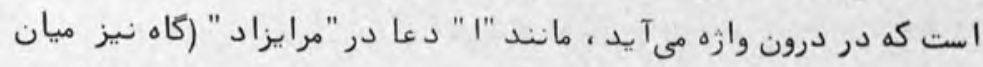

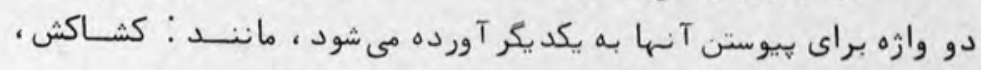
لبالب)

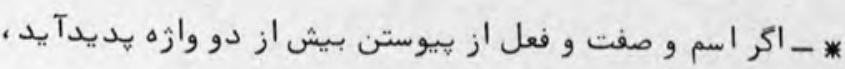

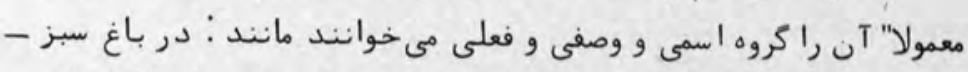

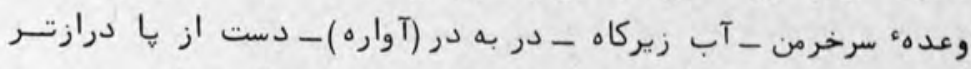

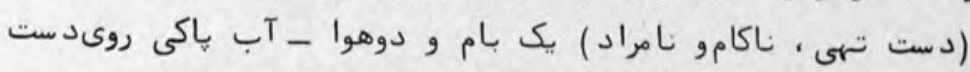

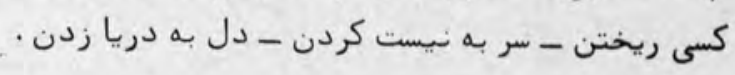


كلاب _ كاروا نسرا - خون بسها ـ نوشدارو _ كاو زبان (نام كياهى دارويى )

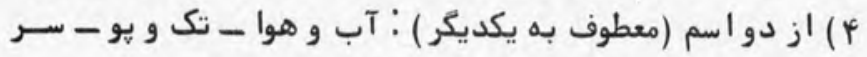

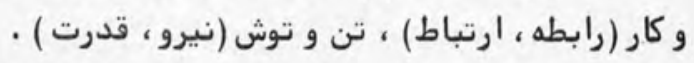

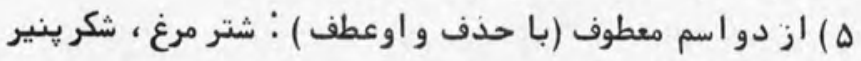

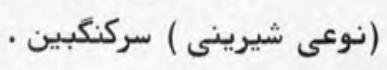

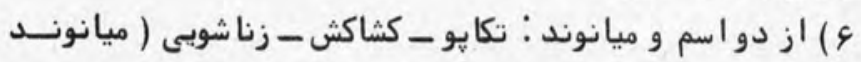
"ا " اينجا معنى و اوعطف دارد ) .

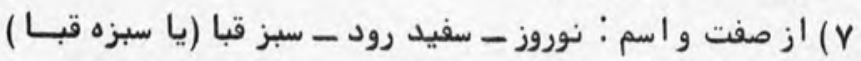

$$
\text { سياه بيشه (نام جايى است ) - زرد كوه . }
$$

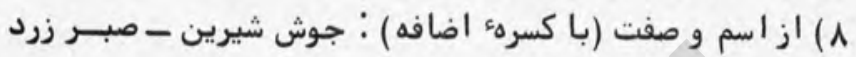

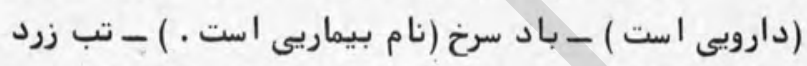

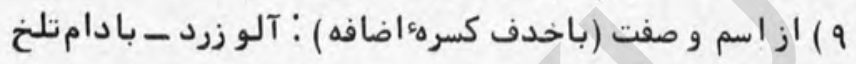

$$
\text { جوب سفيد - خيار شور }
$$

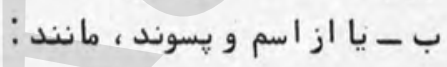

م 1 ) اسم + ستان (يسوند مكان و زمان ، و كاه براى ساختن اسم

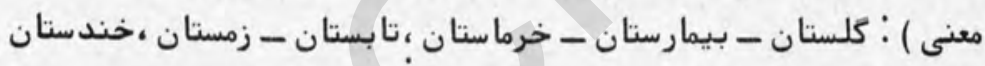

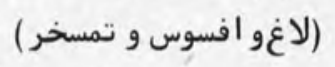

$$
\text { + + زار : لاله زار _ كلززار _ درختزار }
$$

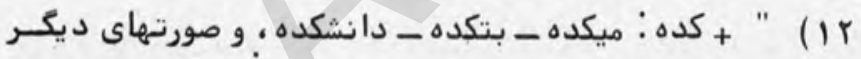

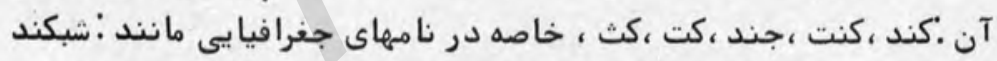

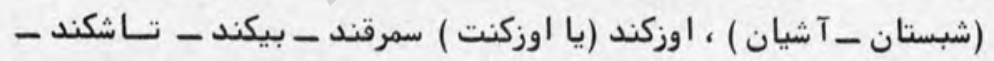

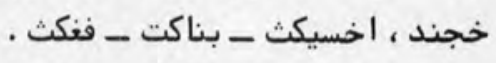

$$
\begin{aligned}
& \text { " + لاخ: " د يولاخ - سنكلاخ }
\end{aligned}
$$

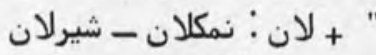

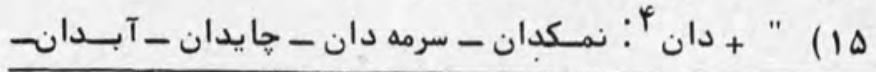

ب - امروز در زبان كفتار كاهى يسوند "ى " (براى مكان ) نيز دين

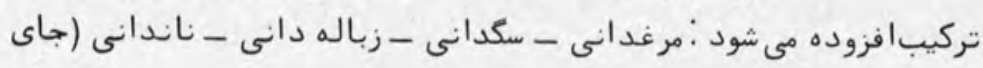




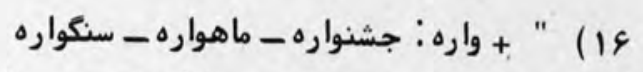

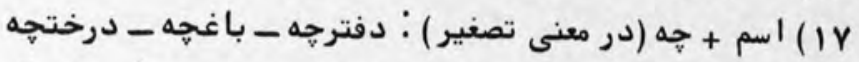

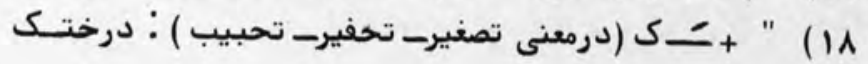

$$
\text { مردك - مادرى }
$$

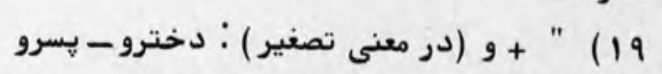

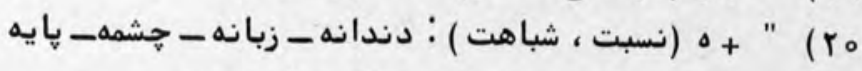

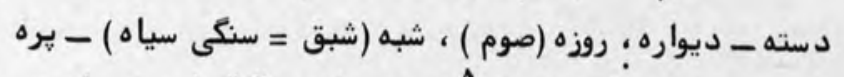

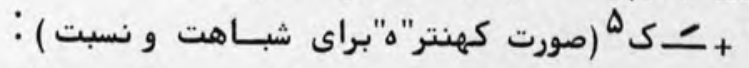

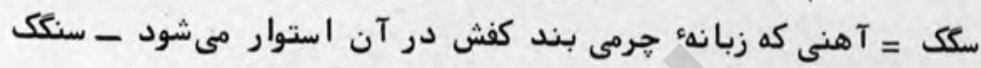

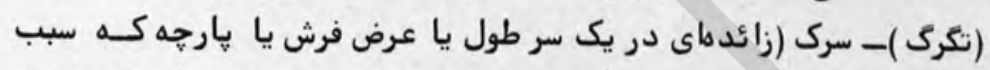

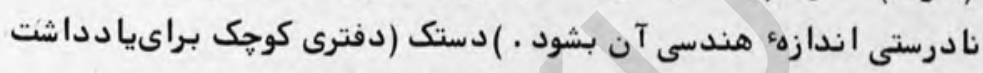

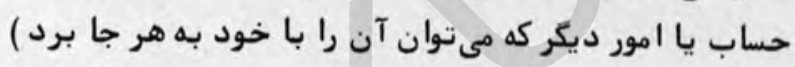

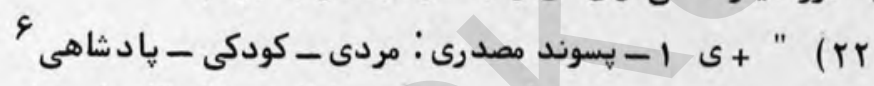

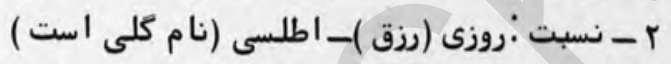

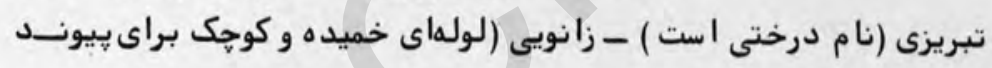

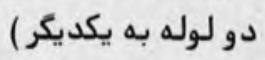

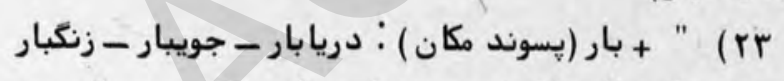

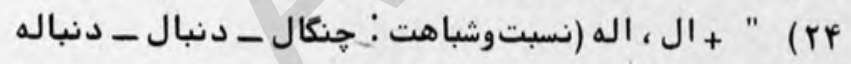

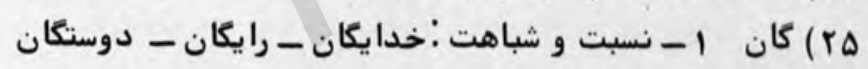
فرزندكان

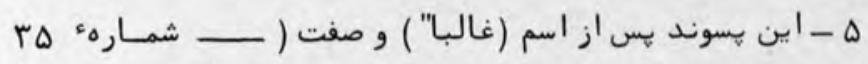

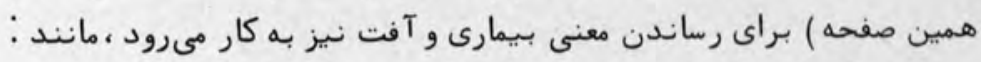

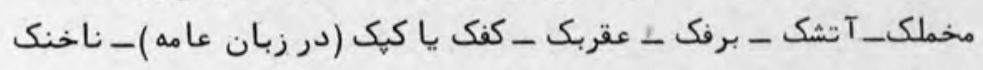

$$
\text { (و ناخنهء صورت ديكر آن ) - خيارى }
$$

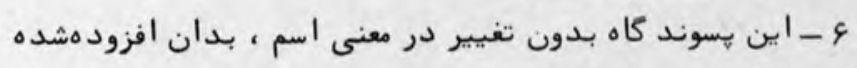

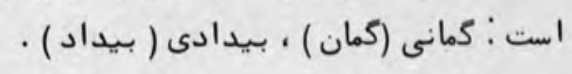




\section{FrY}

r- نسبت و مكان (نصورتتهاى معربآن : جانح غانح

قان ) در نامهاى جغرافيايى : سمنكان _كوركان - آذربايجان ( آتورياتكان

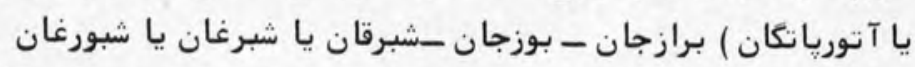

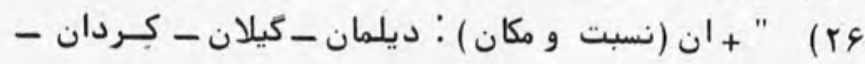

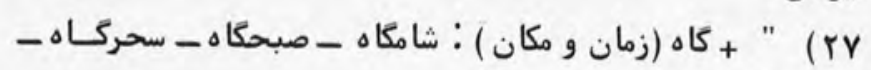

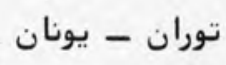
كشتاركاه _ داغكاه _ دامكاه

1 ) اسم + انه (يسوند نسبت ) : ماها نه (يولى كه د ربرابرخدمت يا كارى مداوم در هر ماه به كسى يرداخته مىشود ) - شاكردانه - صبحانه

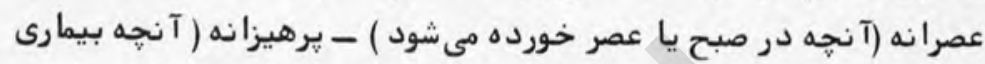
كه در يرهيز است مىتوا ند خورد و او را زيانى ندارد ) - خدمتانه ( آنهه

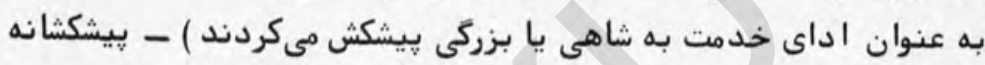

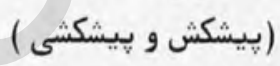

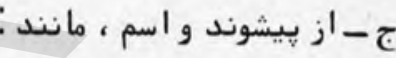

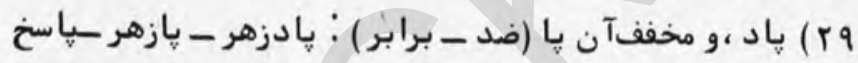

باداش

مro دش و دشت + اسم : دشنام - دشياد يا دشتياد (غيبت).

$$
\begin{aligned}
& \text { د - يا از صفت و هسوند ، مانند : }
\end{aligned}
$$

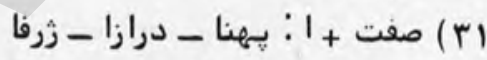

$$
\begin{aligned}
& \text { rrr) صفت + نا : درازنا _ فراخنا ـ تنكنا }
\end{aligned}
$$

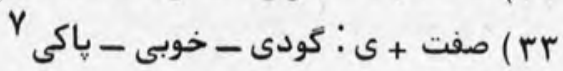

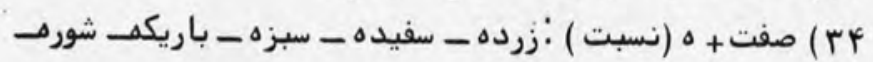

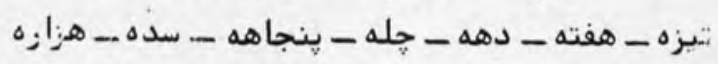

هrr) صفت + - ـ (صورتكهنتر "ه" ) : زردى (كزر ) - سياهك ( زنك كندم ، و نيز فهرست ، ريز ) - سرخك (بيماريى است ) - سفيدى

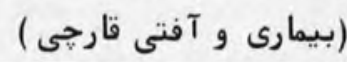

V - اين يسوند كاه براى رساندن مكان نيز به اسم ياصفتافزوده

$$
\text { مىشود : نانوابى (دكان نانوا ) - قصابى - زركرى - سنككى }
$$




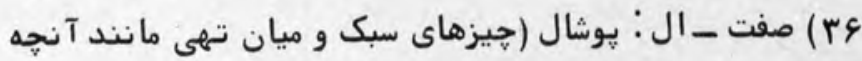

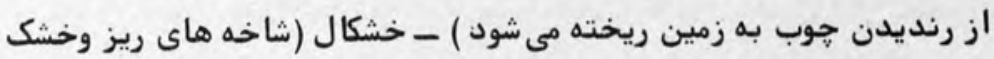
شده درخت

\section{صفـت مســركب}

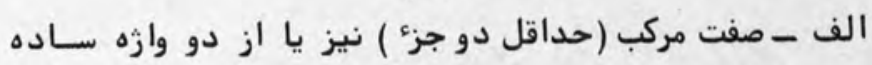

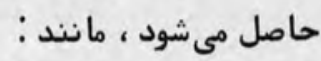

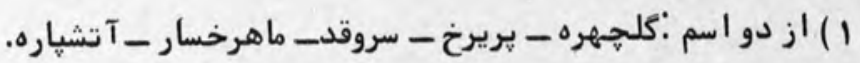

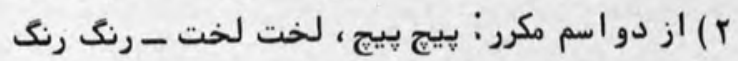

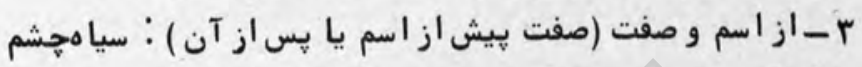

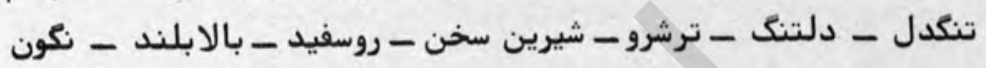

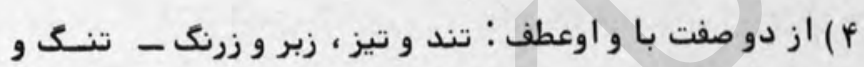

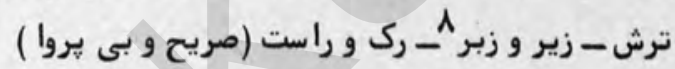

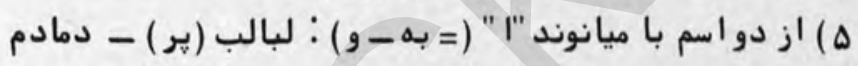

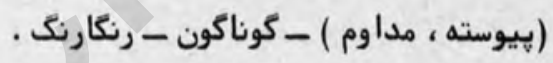

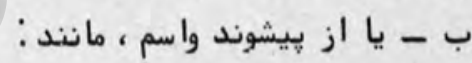

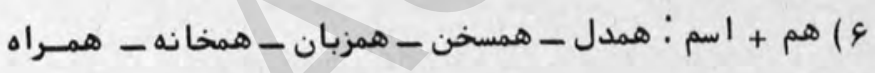
همكار

$$
\text { ) دش + اسم : د شخوى - د دشكام }
$$

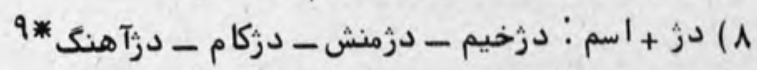

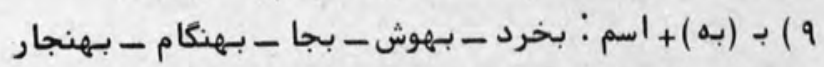

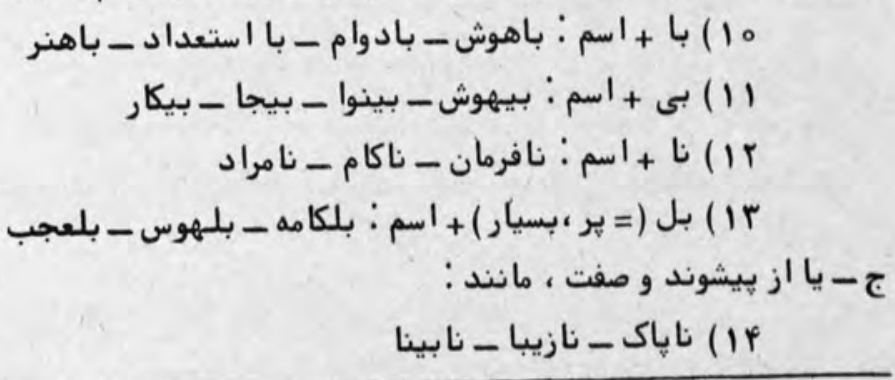




\section{Frq}

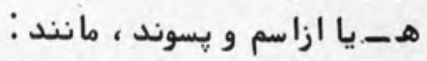

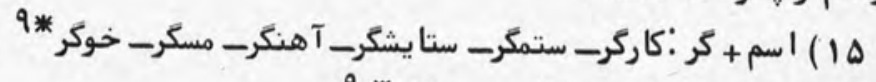

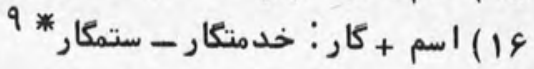

ا سمه مند : خردمند - هنرمند - بهره مند ، واومند (صورت

$$
\text { كهنترمند ) : برومند _ تنومند }
$$

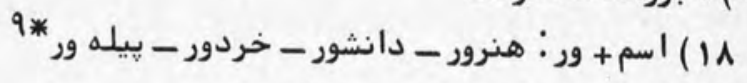

$$
\text { 19 1) اسم + وار : مردوار - ماهوار }
$$

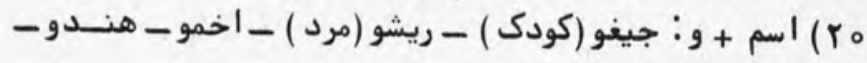

$$
\begin{aligned}
& \text { برزو- ترسو } \\
& \text { 9** }
\end{aligned}
$$

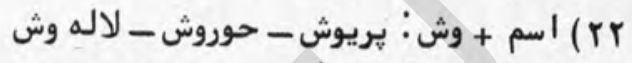

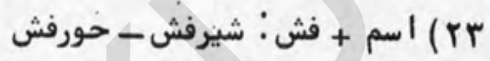

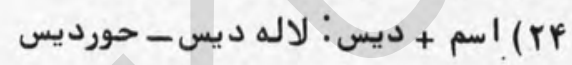

$$
\begin{aligned}
& \text { ه ا سم + ديز : شبديز (سياه) } \\
& \text { ع ا ) اسم - وند : سكوند - كاكاوند }
\end{aligned}
$$

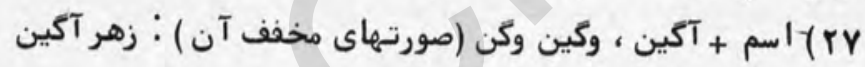

$$
\text { غمكين - اندوهكين - شرمكين - شوخكن }
$$

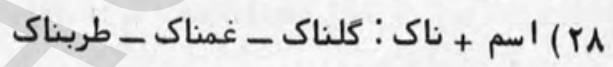

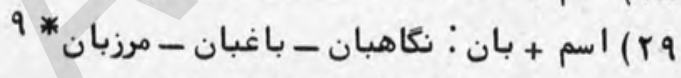

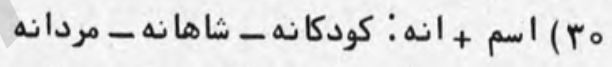

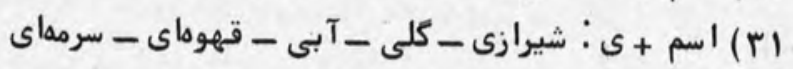

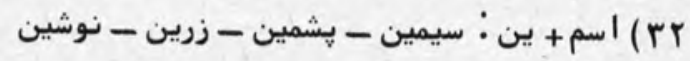

$$
\begin{aligned}
& \text { rrr ) اسم + ينه: سيمينه - زرينه - هشمينه }
\end{aligned}
$$

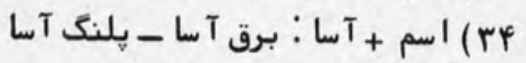

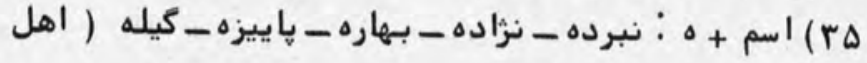

كيلان = كيلى (ن)

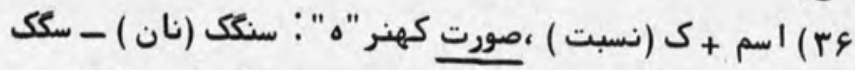

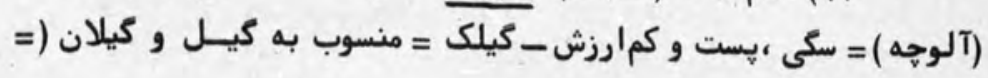


دورهء pro

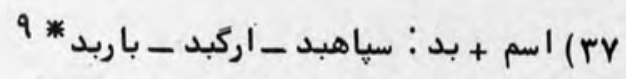

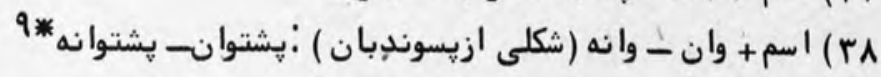

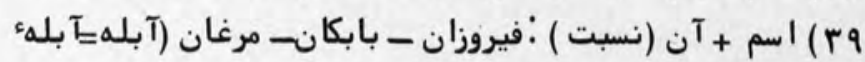

استر ) fo اسم + ون : سترون واسترون هر دو به يك معنى (عقيمونازا

مانند استر )

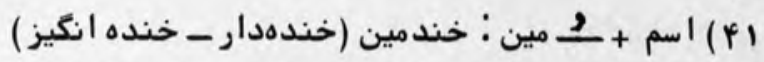

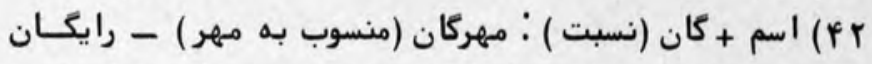

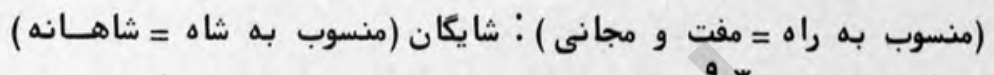

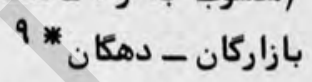

، أf ) اسم + يسوند ال يا ار (شباهت ) :انكشتال ، انكشتار (باريك

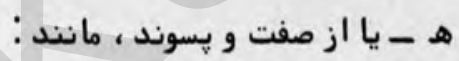

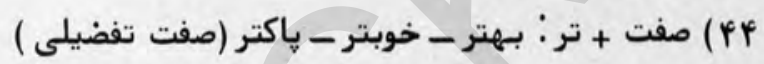

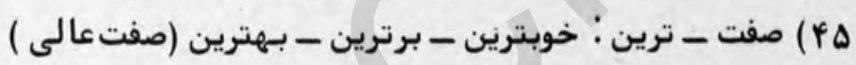

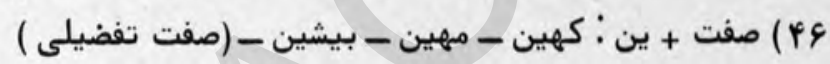

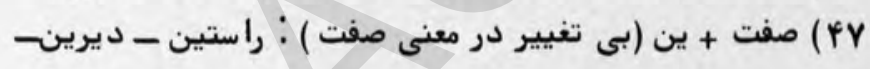

كدامين

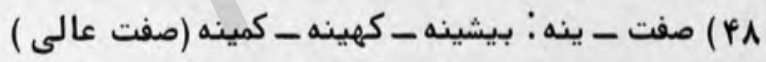

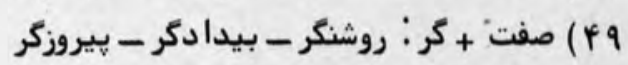

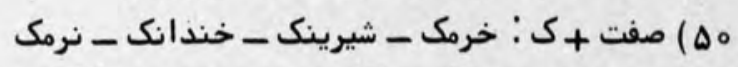

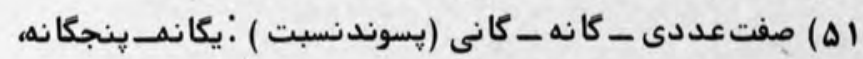

$$
\text { دوكانى (مثنوى ) - جهاركانى (رباعى ) مدرد ) }
$$

(Ar (Ar

* 9 - بسيارى از اين كونه صفات غالبا" به جاى اسم و همجهون اسم 


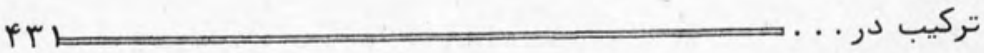

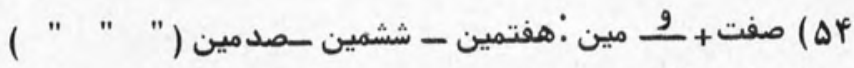

(هD

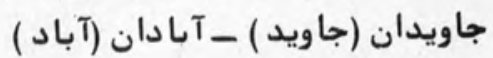

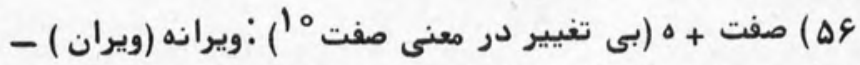

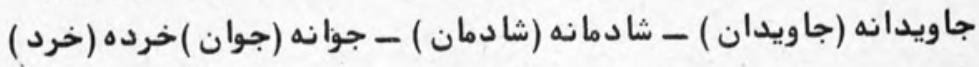

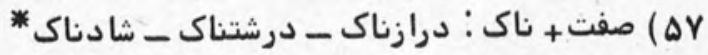

(به بخش فعل نيز مراجعه شود )

مانده دارد

مصطفى مقــربسى مانى دارد

ماـاين كونه صفتها در تركيب خاصتا" بسيار به كار رفته است :

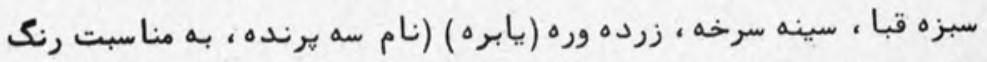

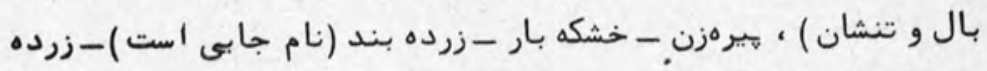

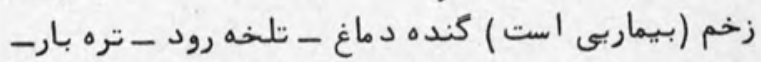

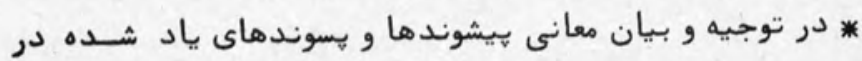

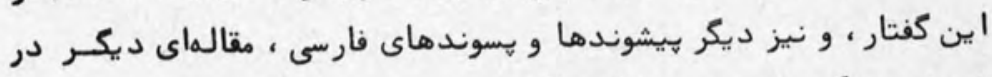

فرصتى ديكر در سخن خواهد آمدم. 


\section{جوا انسانى خواست سوسكى شود ؟}

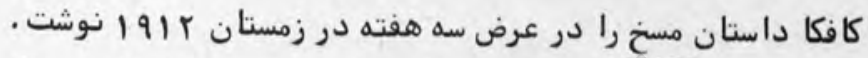

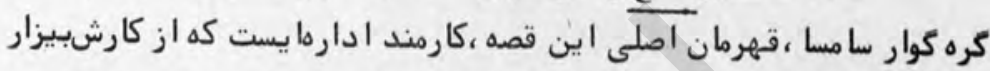

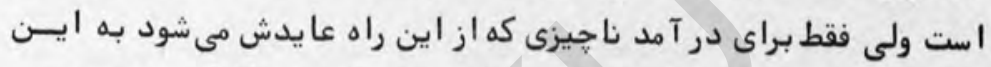

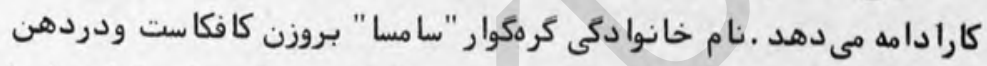

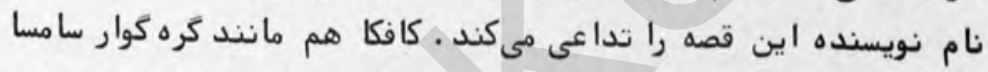

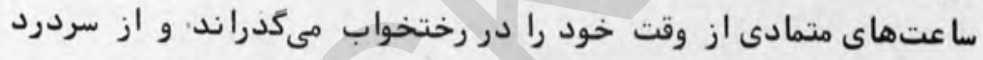

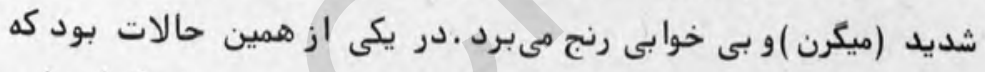

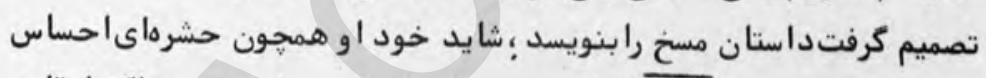

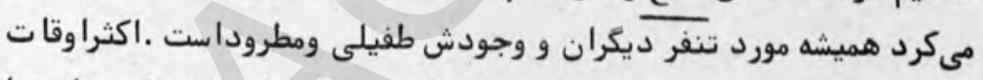

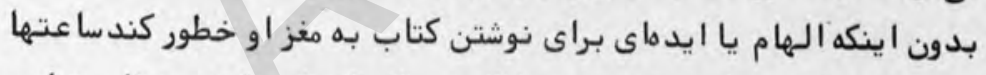

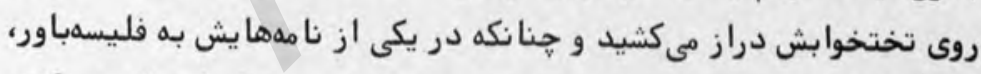

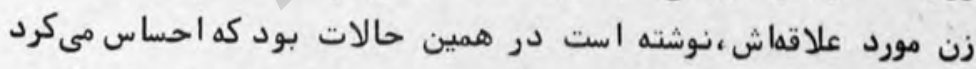

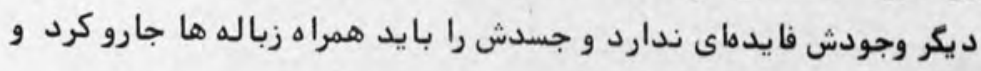

مسخ كافكا دا ستان تنهايى انسان معاصر است .انسانى كه فريب

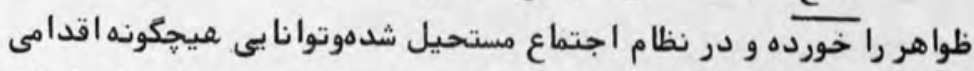

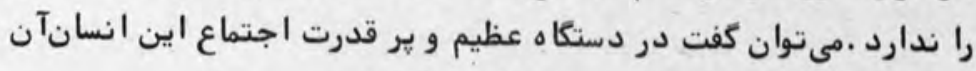

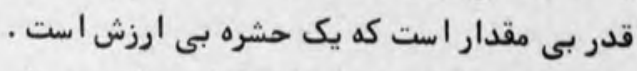

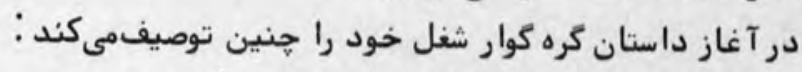

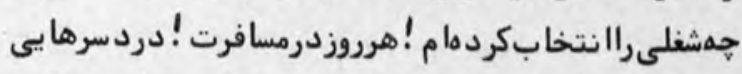

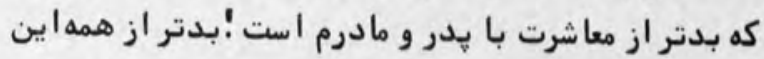


زجرمسافرت يعنى عوض كردن ترنها ، سوار شدن ـهترنهاى فرعى كه ممكن است ازدست برود ،خوراكهاى بدى كهبايد

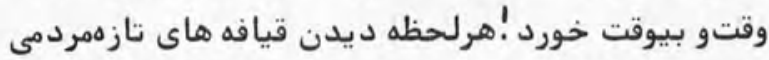
كه انسان ديكر نخواهد ديد و محال است كه با آنها طرح

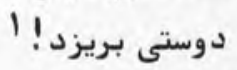

كره كوار هم از شغلش ناراضى است و هم از رئيس ادارهاش كه انسان بىاحسا سى استو خود را خدا يى مى داند كه ازيشت ميز بهكارمندان حكومت مىكند .هيج راهى براى فرار از او و آن دستكاه ظالمى كه او او نمايندهاش بايد باشد نيست .حتى با بيمار شدن هم نمىتوان از دست او او بر

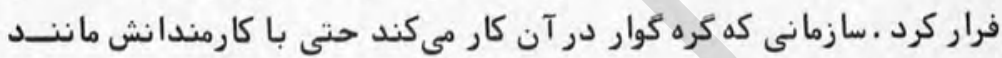

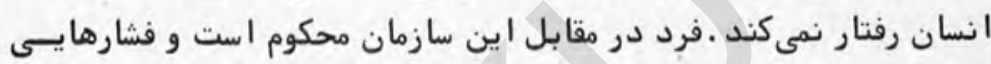

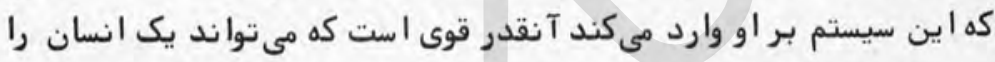
مسخ كند .در اين موقع ديكر زندكى جنبه انسانى خود را براى فردى كه قربانى اين نظام شدها ست از دست ميدهد .فرد ناحار است كور كورانه

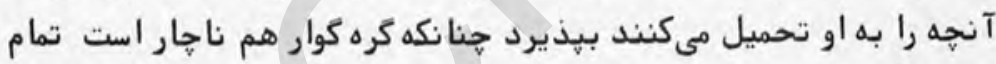

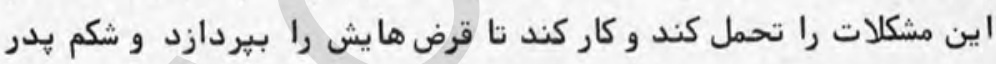
و مادر و خواهرش را سير كند.

داستان مسخ از سه بخش تشكيل شدهاست . "ميان بخش اول و دوم يك روز فاصله ولى بين بخش دوم و سوم فاصله بيشترى وجود دارد .

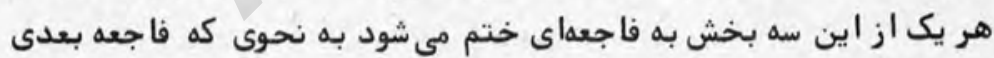

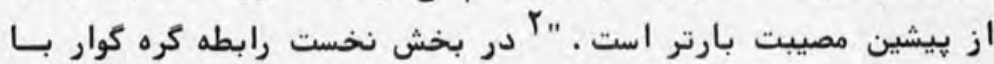

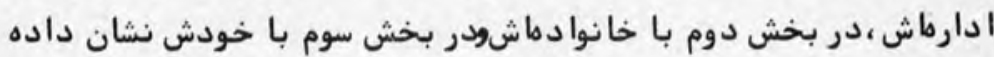

بخش نخست هم از لحاظ زمانى و هم ازلحاظ مكانى محدوداست. ماجرا در اتاق كره كوار اتفاق مىافتد . ساعت شماطهاى كه دركنجه تيكتاك مىكند دائما"به او يادآورى مىنمايد كه برده اجتماع و تابـع مقررات

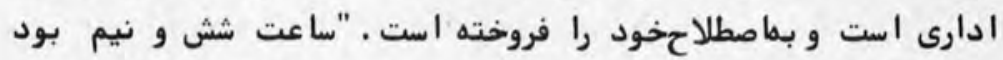

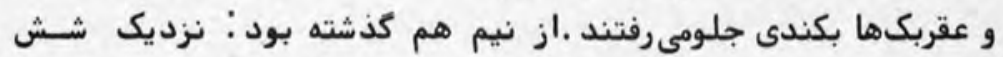




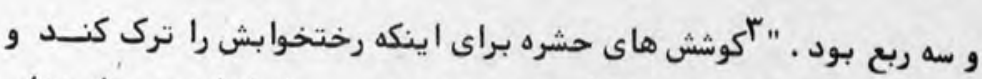

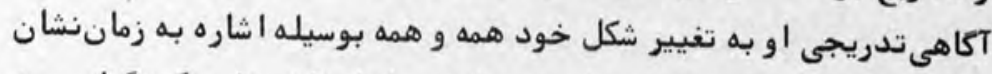

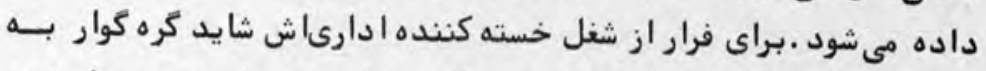

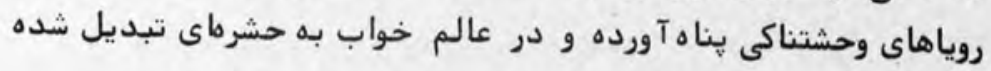

در بخش دوم كتاب زمان تدريجا" مستحيل مىشود . بخشاول

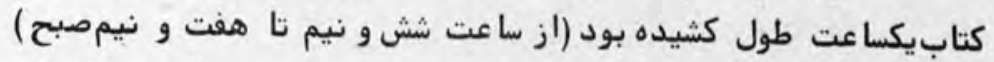

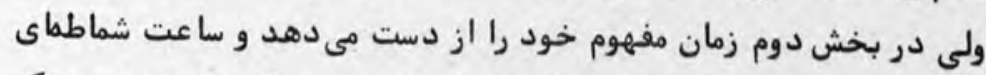

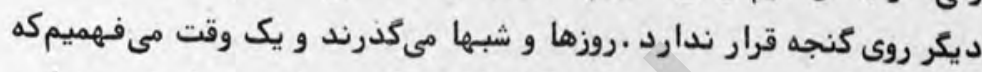

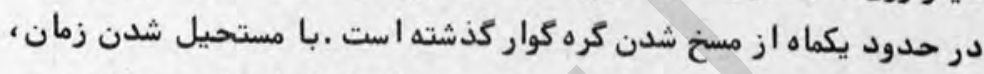

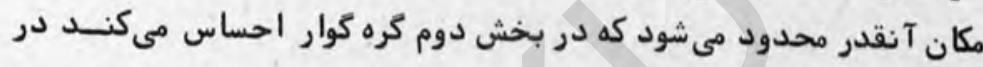

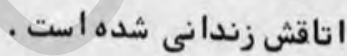
سرانجام كره كوار با واقعيت بدبختى خود در در بخش سوم كتاب

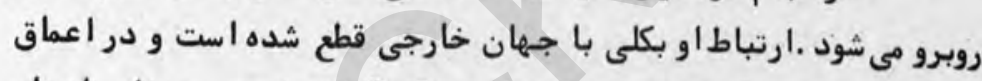

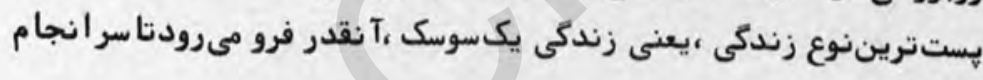

بنظر مىرسد كافكا ايده سوسك شدن را از داستا يفسكىكرفتهباشد بميرد.

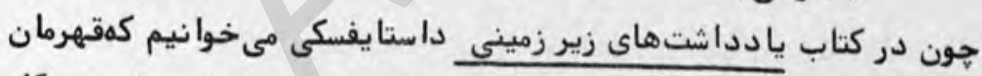

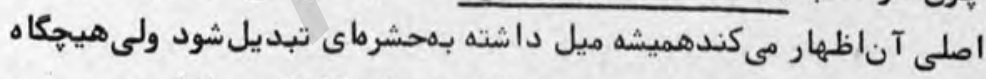

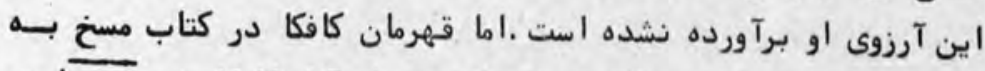

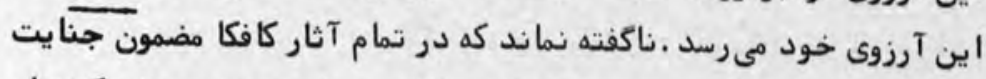

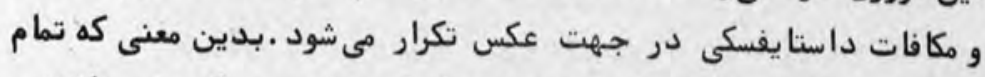

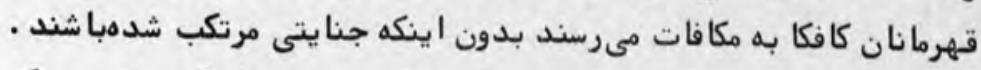

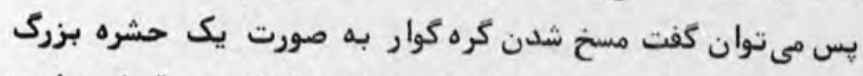

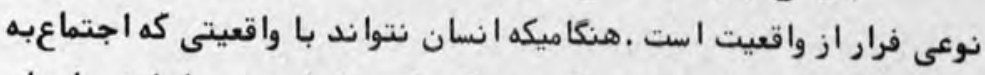

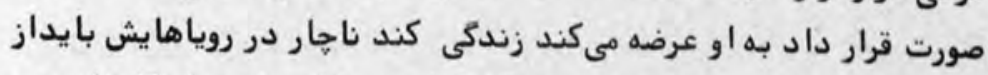

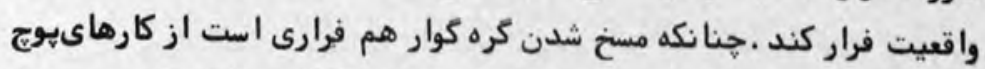

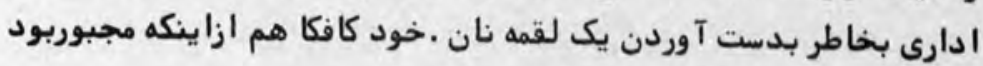




$$
\text { در اداره بيمه براك كار كند رنج مى برد . }
$$

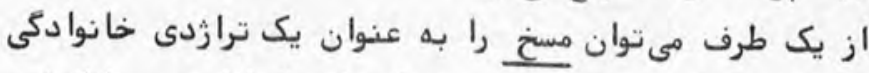

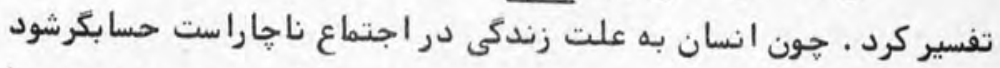

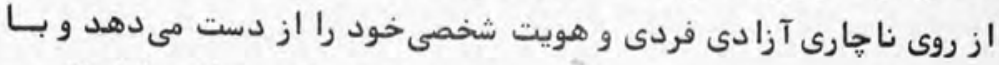

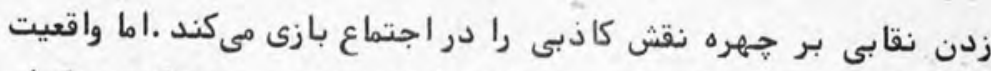

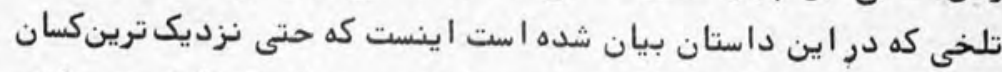

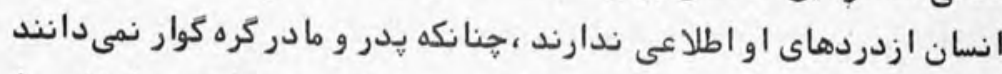

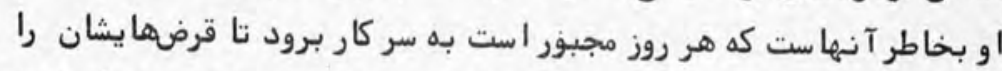

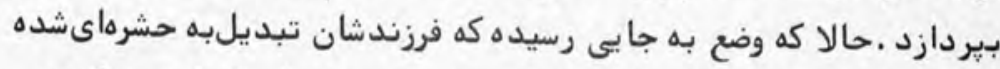

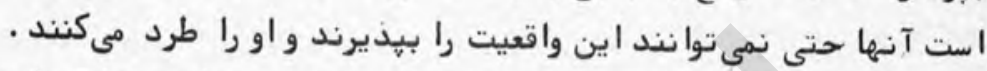

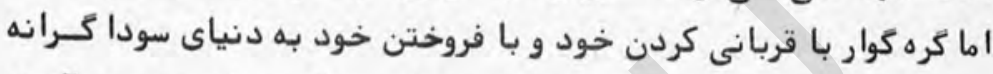

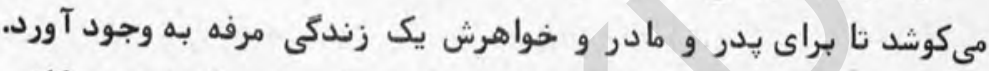

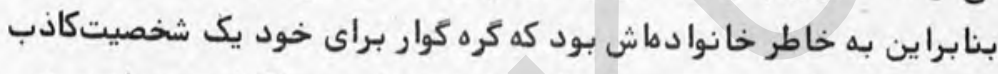

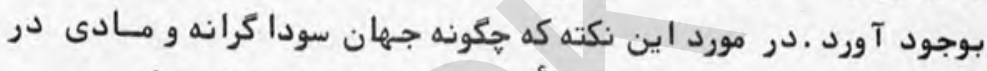

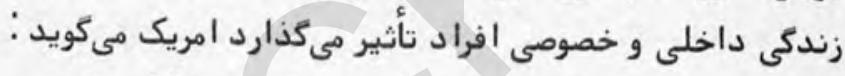

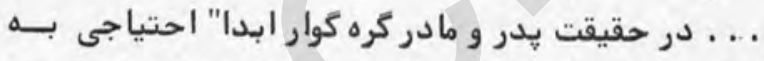

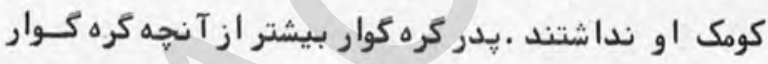

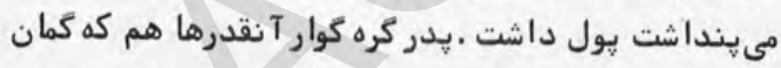

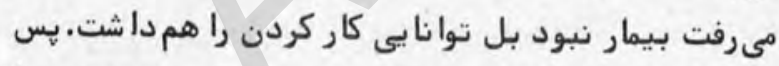

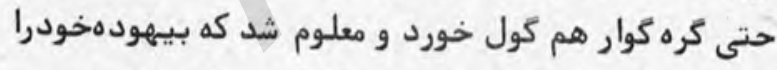

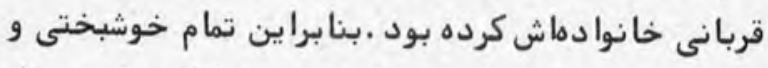

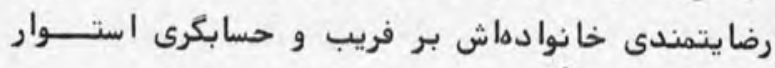

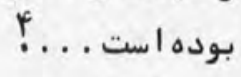

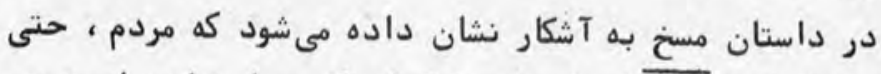

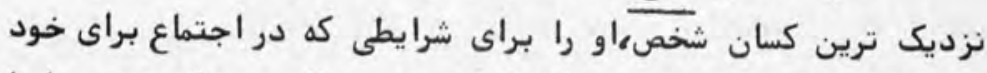

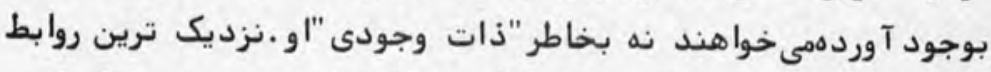

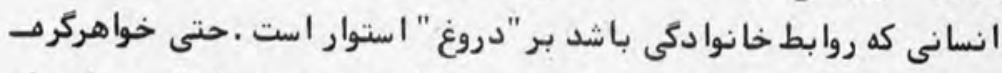

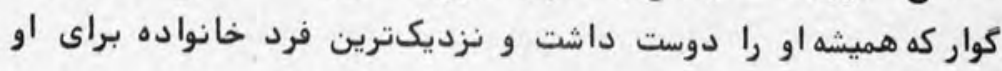




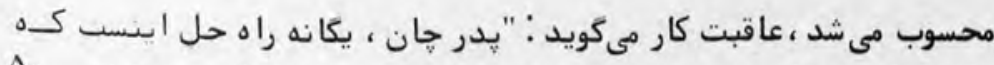
$\Delta$.

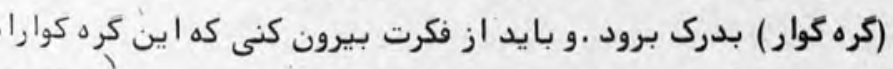

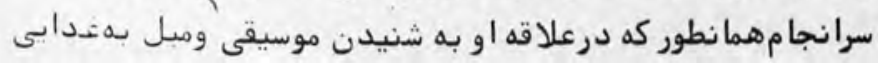

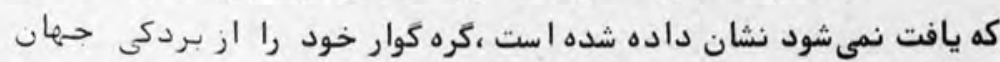

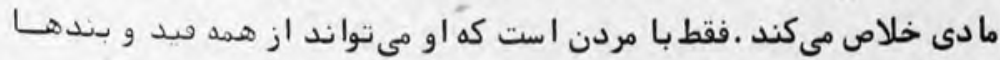

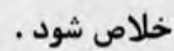

كافكا در اين داستان خواسته است جههان واقعى را كه انسانها

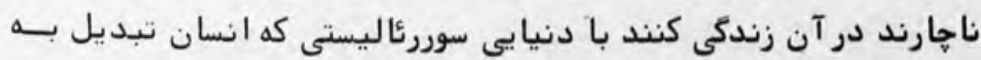

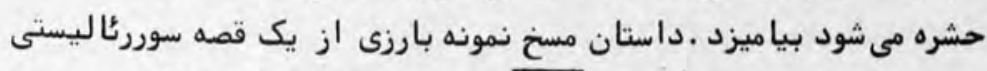

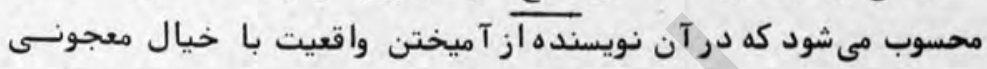

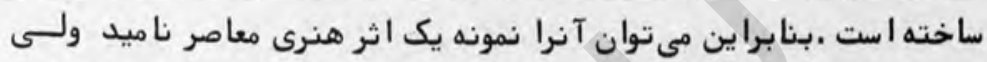

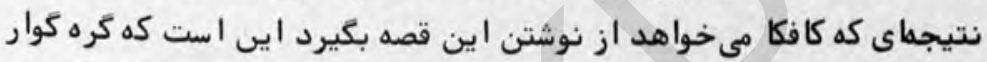

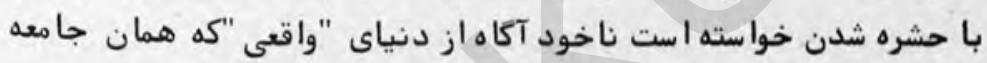

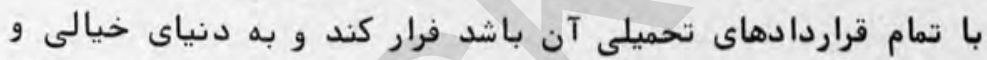

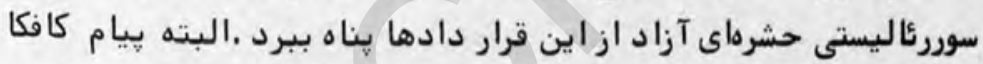

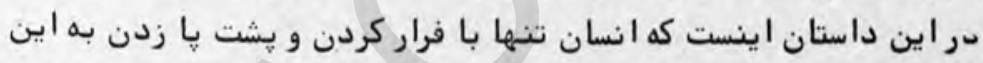

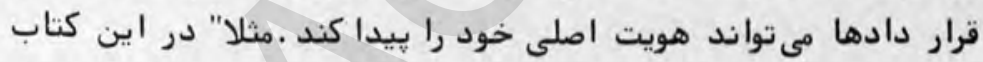

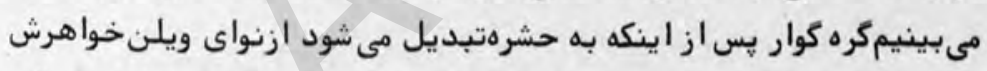

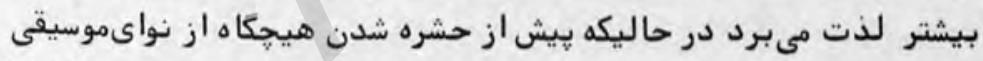

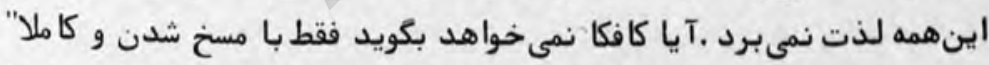

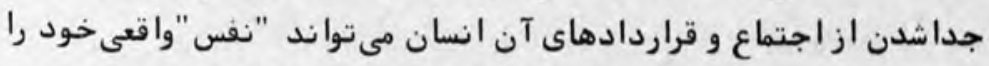

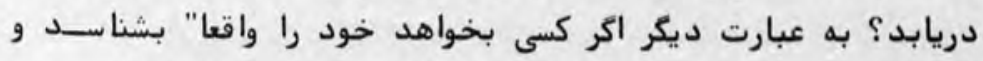

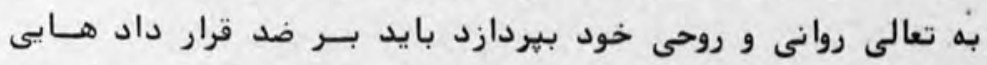

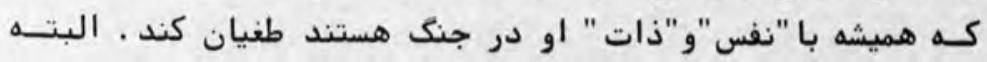

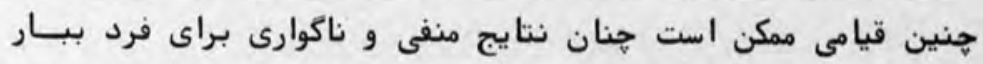

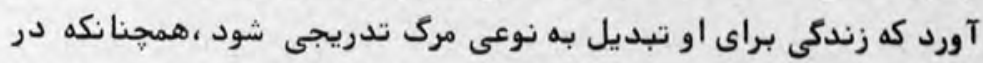

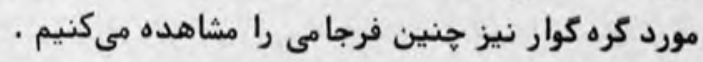

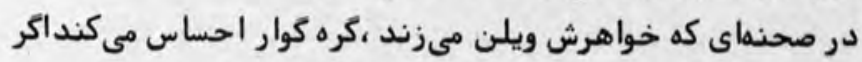




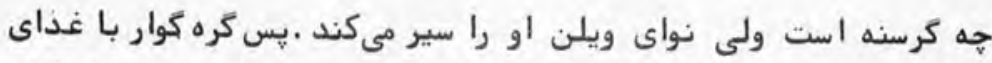

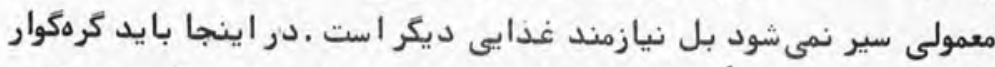

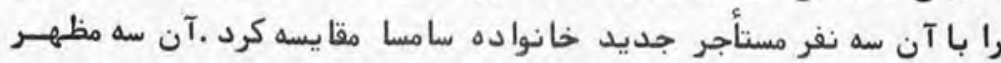

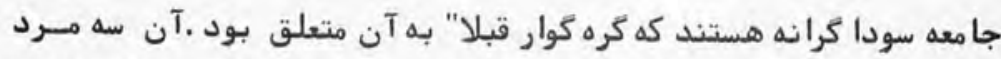

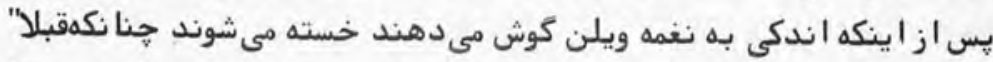

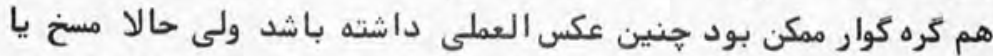

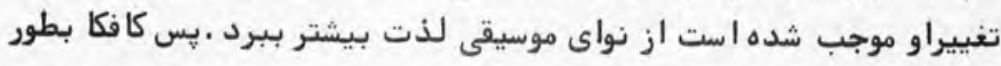

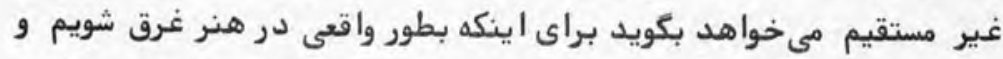

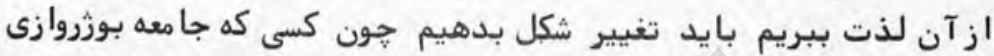

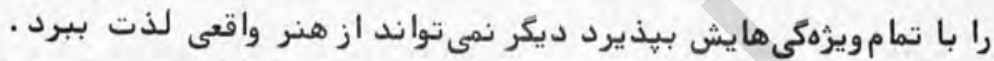

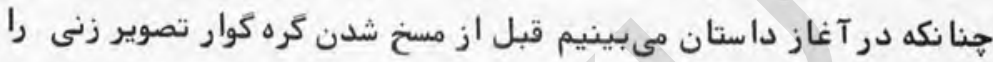

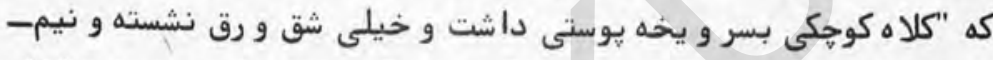

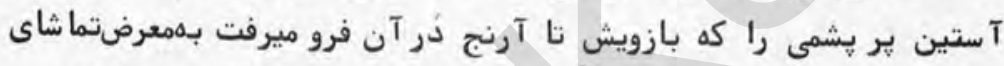

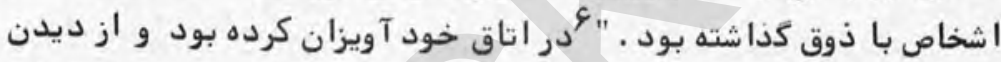

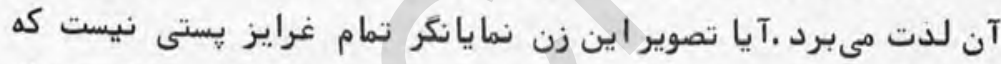

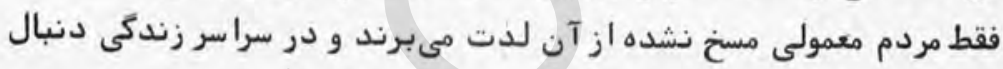

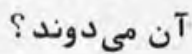
جنا نكه مى بينم موسيقى نقش مهمى را در اين قصه بازى مى كند.

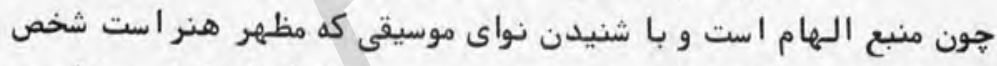

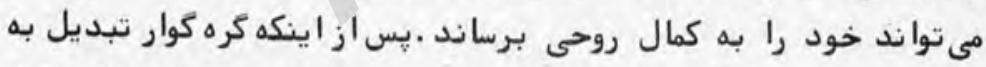

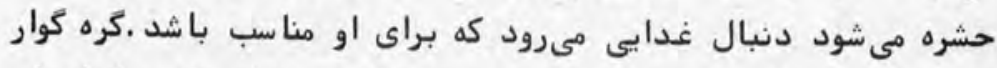

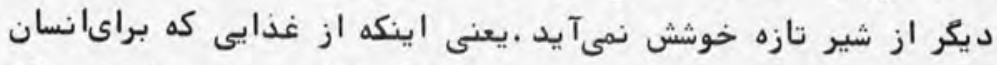

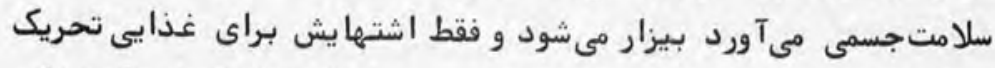

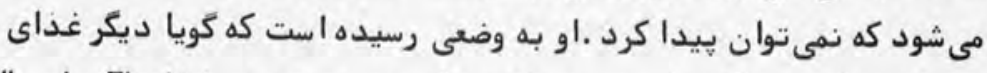

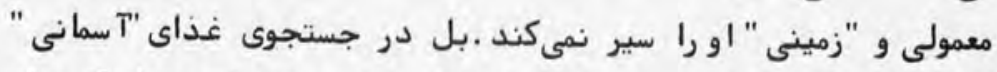

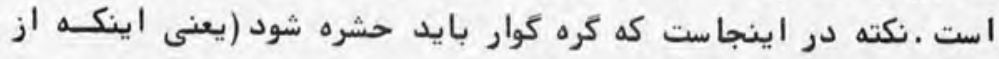

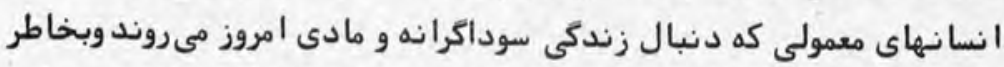

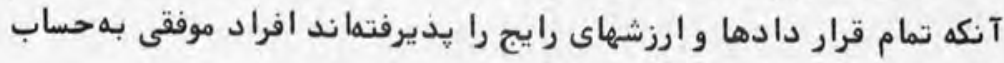




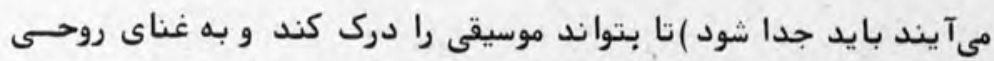

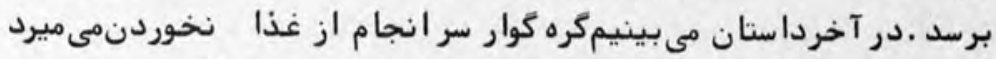

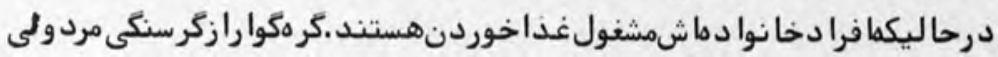

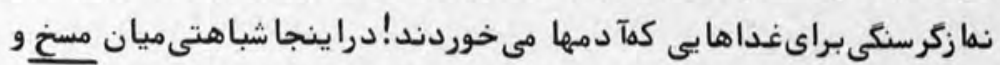

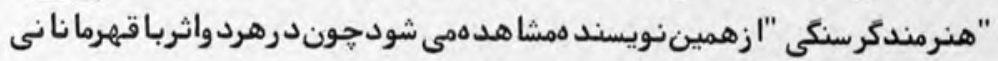

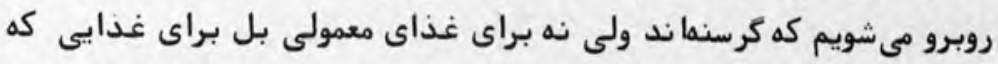

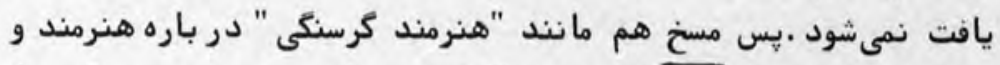

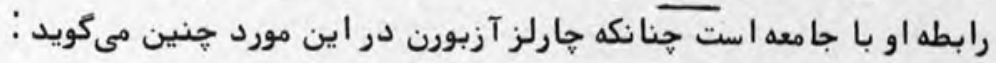

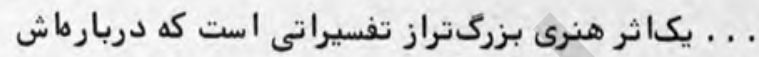

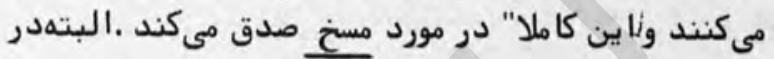

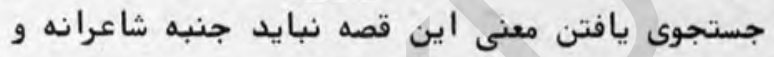
غم انكيز آن فراموش شود .كره كوار ، شخصى كه مه نمى تواند

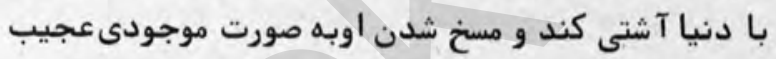

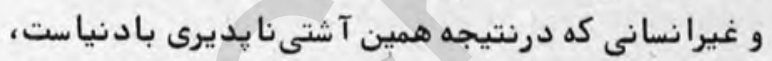

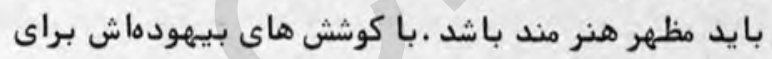

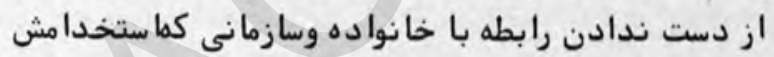

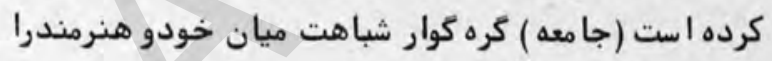

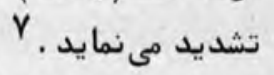

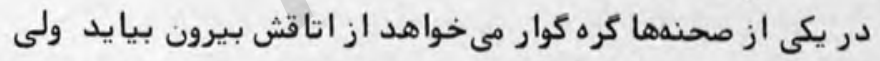

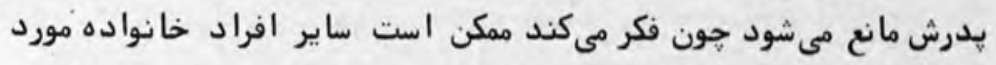

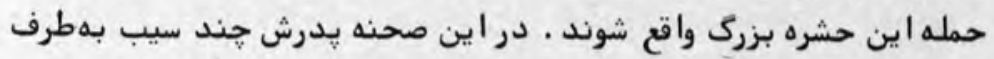

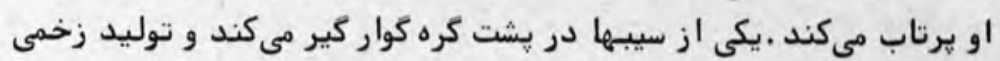

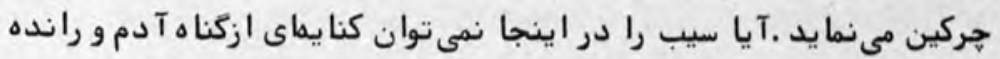

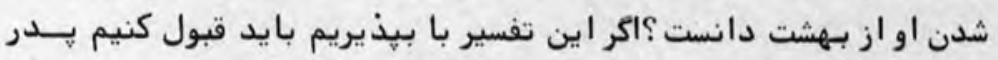

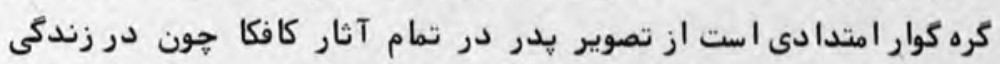

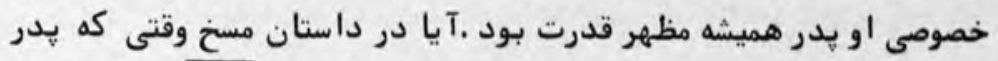

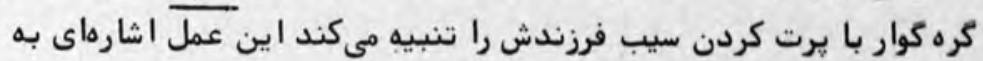

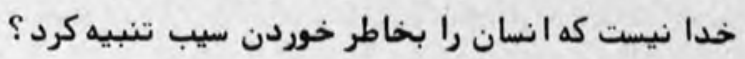


بنابراين آيا دكركون شدن كره كوار از انسان به حشرهمىتواند

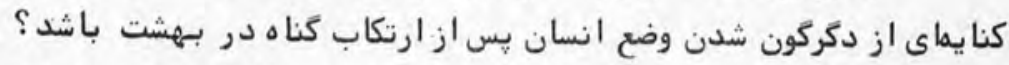
با توجه به اين نكته كه كره كوار يِيش از مسخ شدن و هنكاميكه هنوز انسان بود از شغلش رضايت نداشت آيا مى توان كفت كه انسان هم از بـهشت خحسته شده بود و تمام زيبا بيىها و مزاياى آن را به يك سيب فروخت ؟و

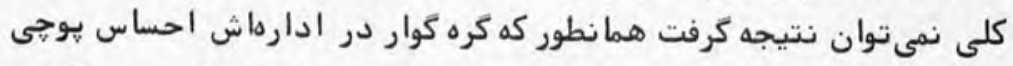
مىكردانسان هم در بهـشت حنين احسا سى داشت بطوريكه يك سيبتوانت حس كنجكاوى او را برانكيزد ؟در بـهشت آدم و حوا تمام آزادىها راداشتيند ولى فقط خوردن سيب از درخت معرفت بر آنها منع شده بود .رانده شدن آدم و حوا از بهشت بخاطر خوردن سيب در اين داستانمعادل راندهشدن

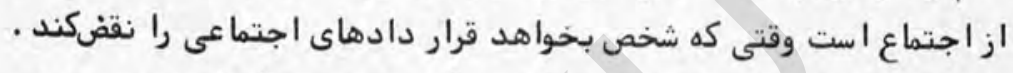
قرار دادهاى اجتماعى هما نـند فرمان خدا در بـهشت مطاع است و سر ييهيى

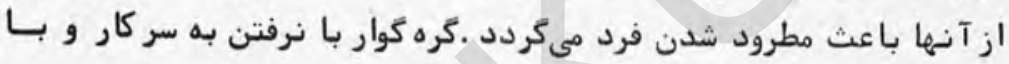
ازدواج نكردن مىخواهد بر خلاف جههت طبيعى اجتماع كام برداردو در

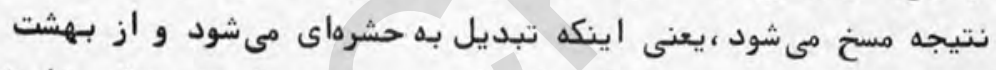

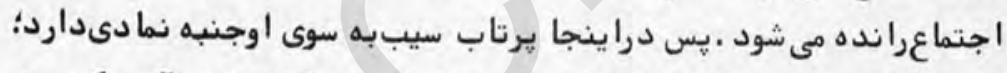
يعنى اينكه هر كسقراردادهاى اجتماع خود را نقض كند مانند آدم كمميوه ممنوع راخورد هبود ازبهرشت راند همى شود . ولى فقط دمطرود بودن اميد رستكارى است هون كرهكوار تنهابا سوسك شدن مى تواندخودرا ازقيدوبندهاىمسخره اجتماع رها كند واز دنياى رجاله ها فرار كند .حيوانات هيحكاه دجار عقدهماى روانى و ناراحتى هاى عاطفى و عصبى نمى شوند حون فارغ از هر

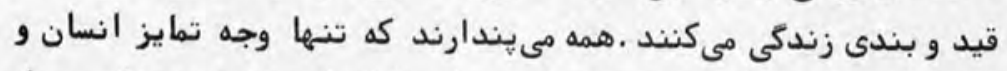
حيوان در تكلم است و جمله "انسان حيوان ناطق است "زبانزد خاص و عام

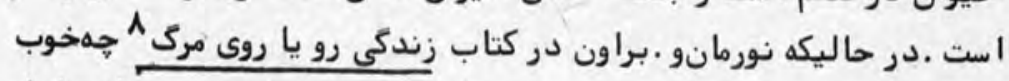

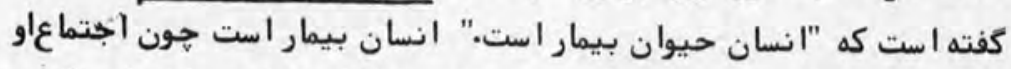

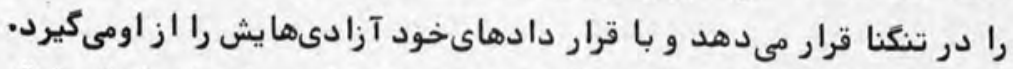

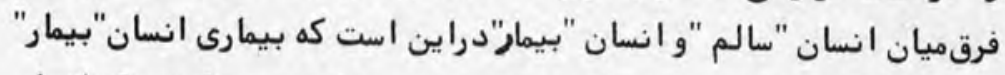
بايدتاحدىباشدكما جتماع آنرابيذيرد . يس ميتوان نتيجه كرفت كه 'نسان 
اجتماعى انسانى است "بيمار" .در مورد اين نكته كه كره كوار با حيوان

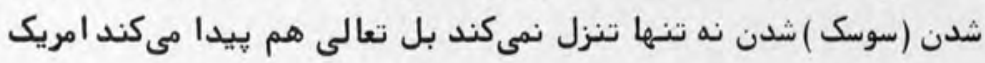

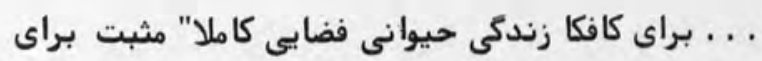

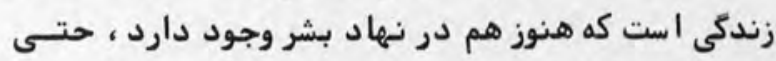

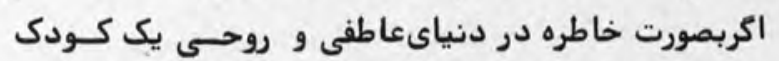

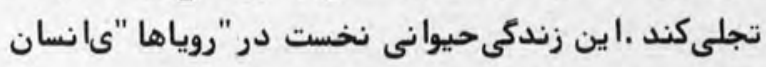

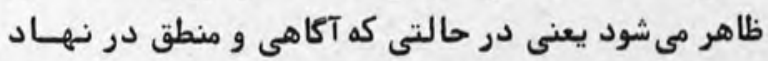

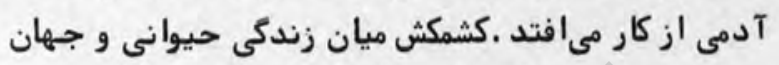

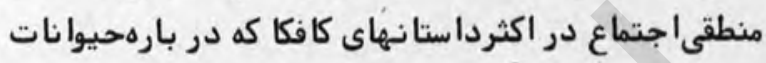

$$
\text { است وجود دارد . }
$$

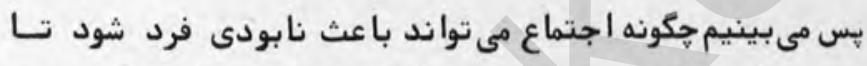

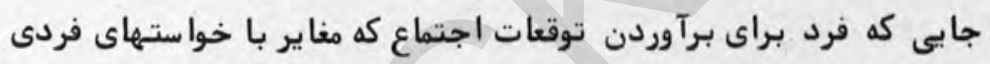

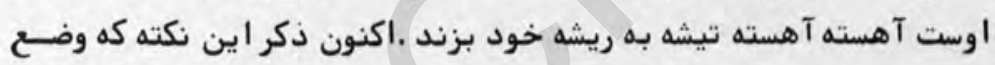

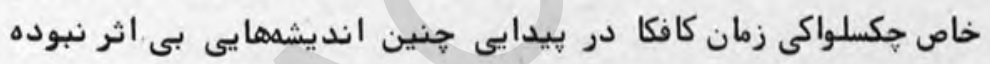

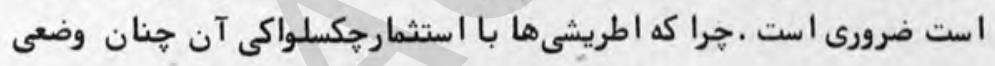

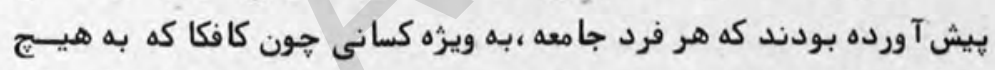

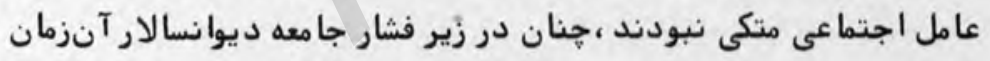

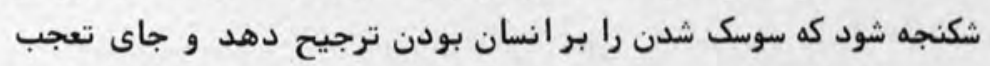

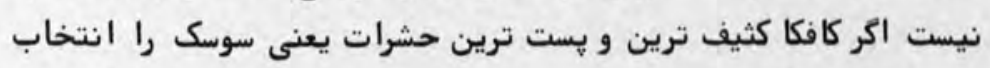

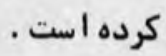

در مورد اينكه مسخ در باره اضمحلالفرد در جامعه بورثوازى است هلموت ريختر مىنويسد:

زندكى بر دردسر قهرمانان كافكا نما يا نكر خطر بزركىاست

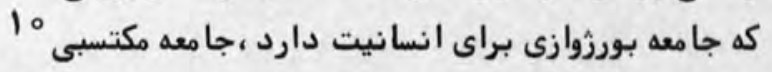

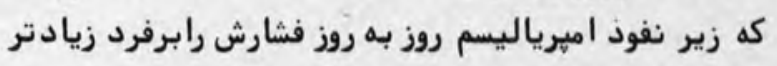

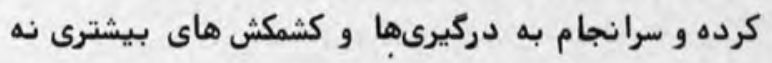


تنها در زندكى اجتماعى بل در زندكى هر خانوادهبه

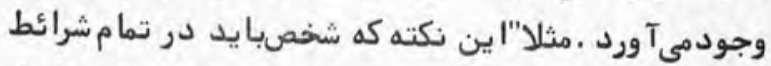

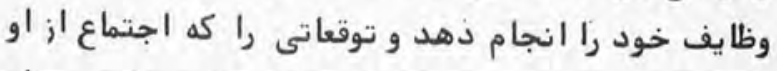

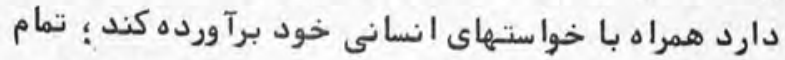

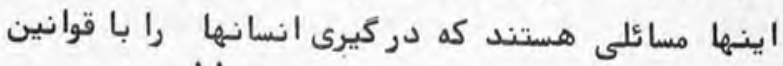

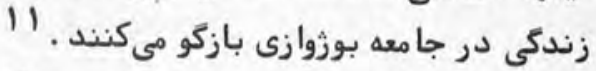

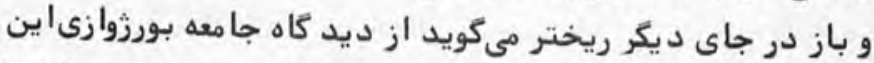

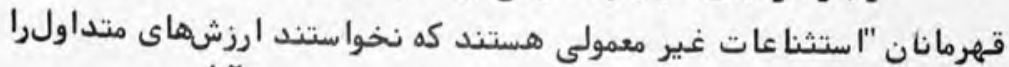

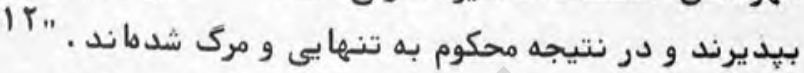

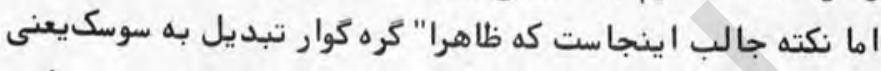

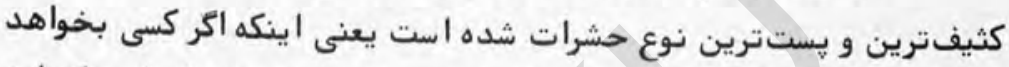

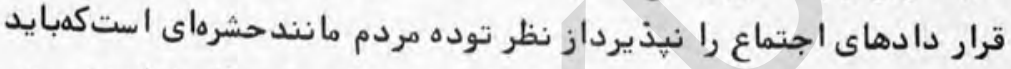

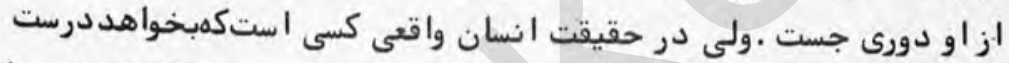

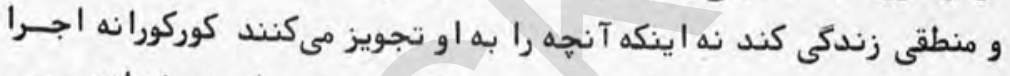

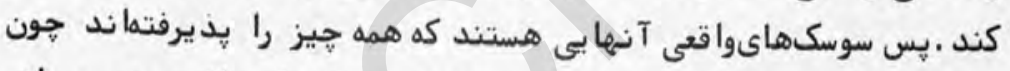

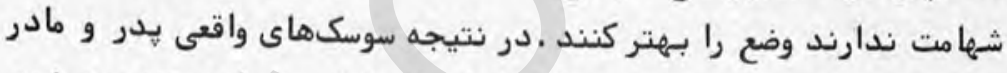

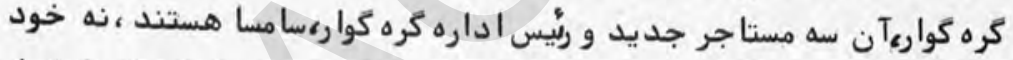

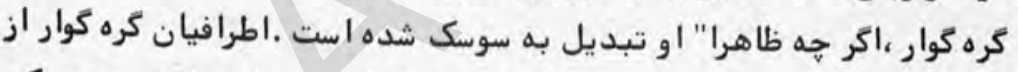

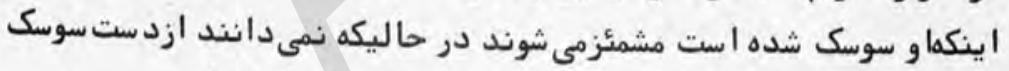

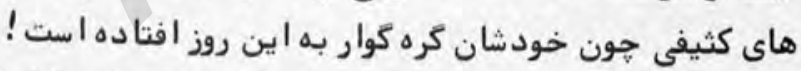

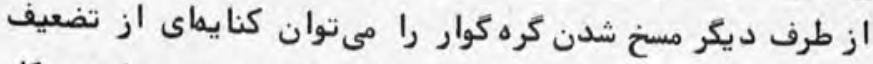

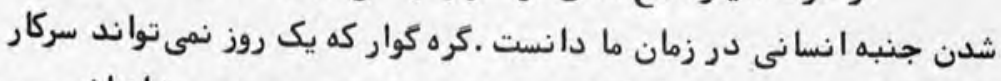

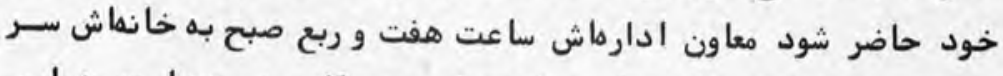

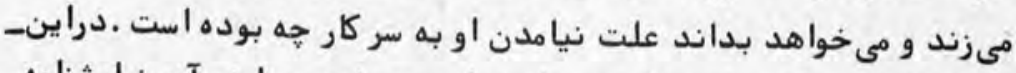

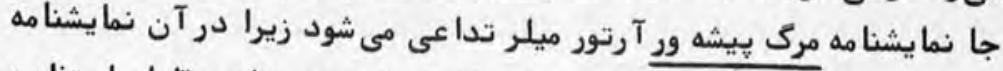

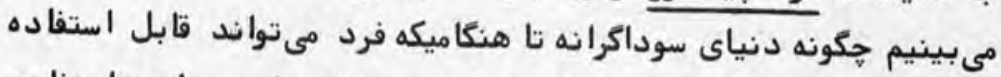

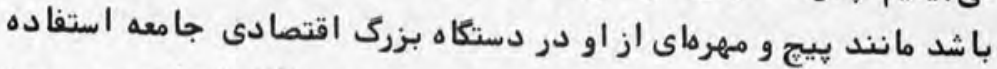

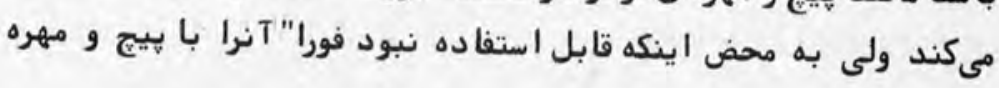


جديدى معاوضه مىنما يد .بنابراين مشاهده مىكنيم كره كوار نه در زندكى

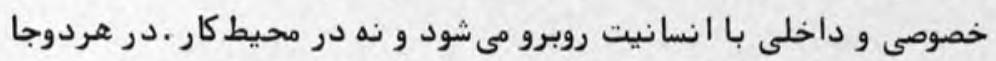

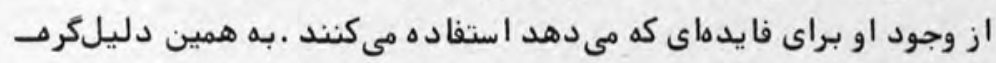

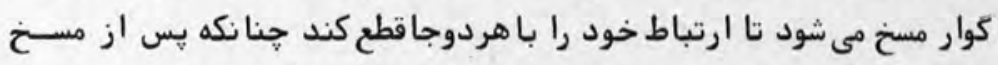

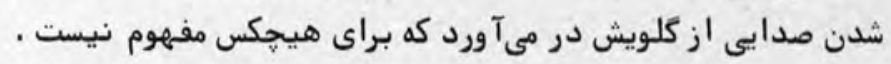

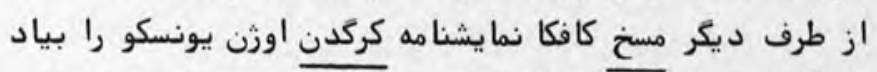

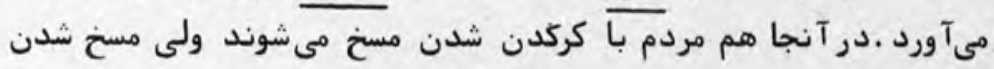

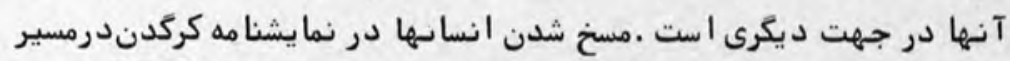

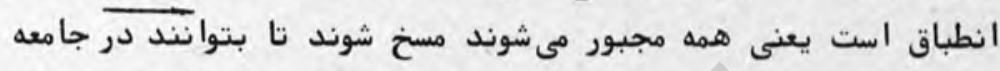

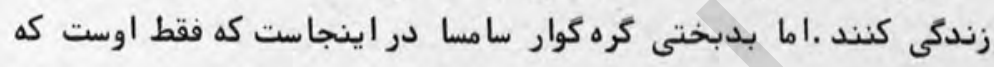

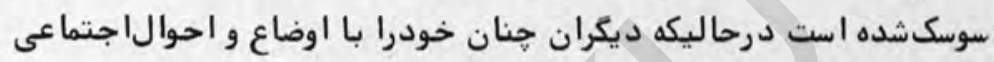

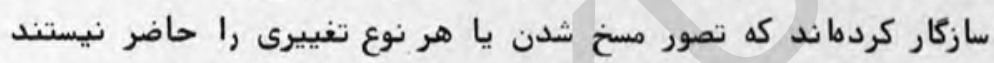

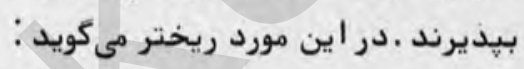

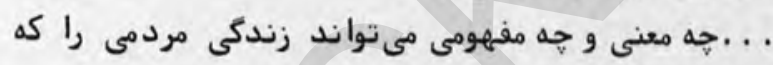

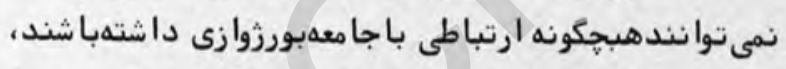

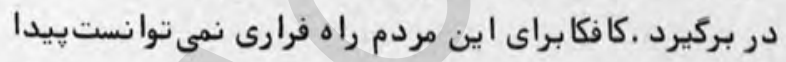

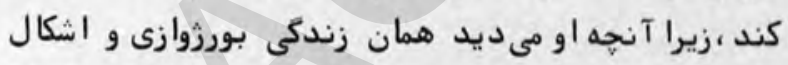

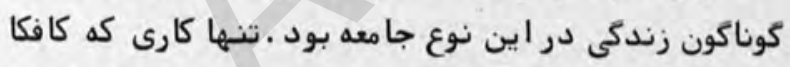

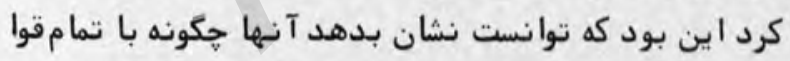

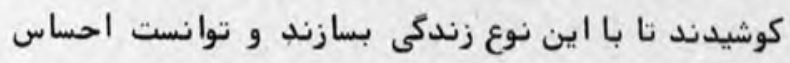

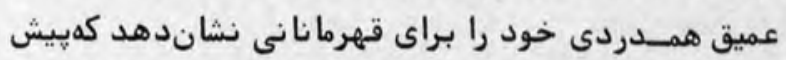

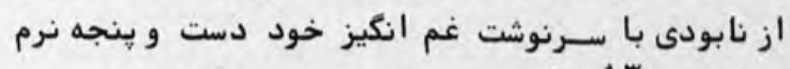

$$
\text { مى ازكردند. }
$$

از نخستين لحظاتى كه داستان آغاز ميكرددد خواننده با اين

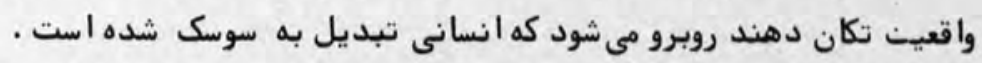

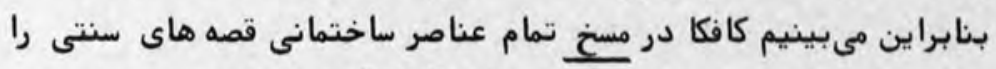

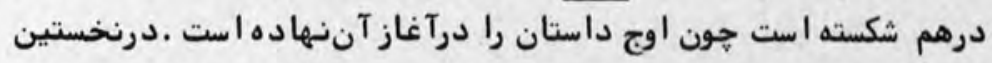
سطور داستان مىبينيم كره كوار يك روز صبح هنكامى كه از خواب بيد بيدار 
مىشود با اين حقيقت تلخ روبرو مى شود كه ديكر انسان نيست بل حشرهاى

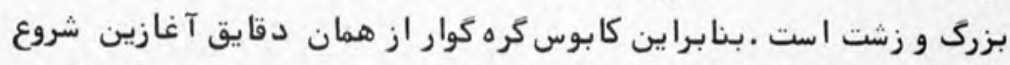

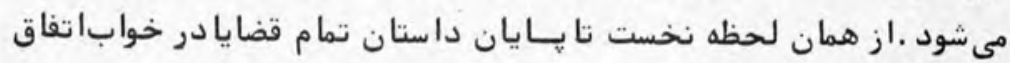

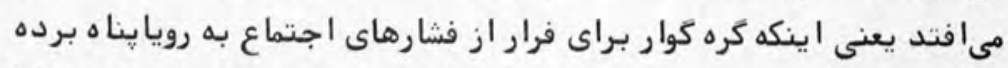

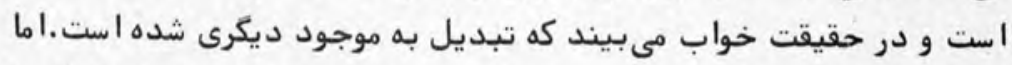

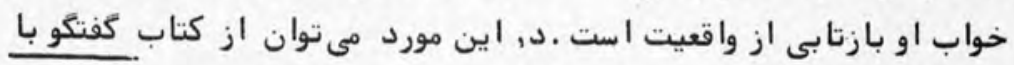

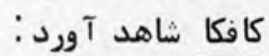

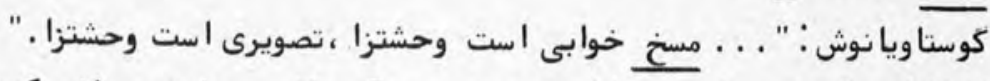

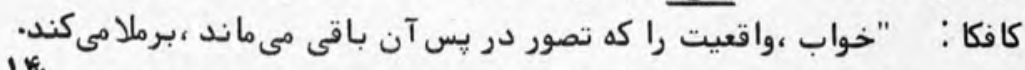
Ifi.

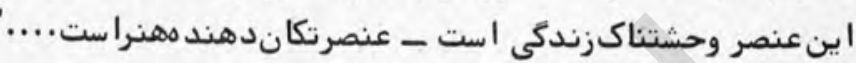

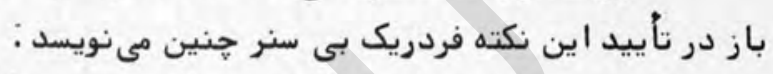

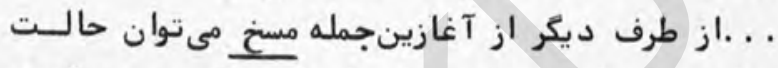

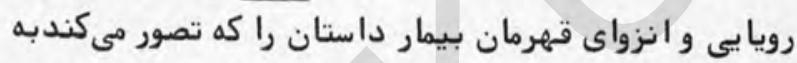

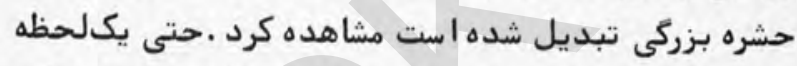

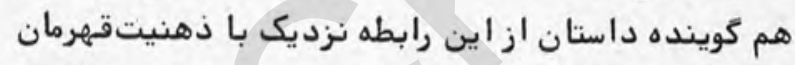

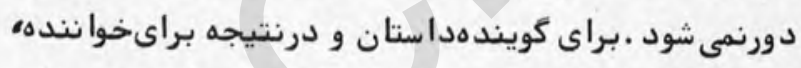

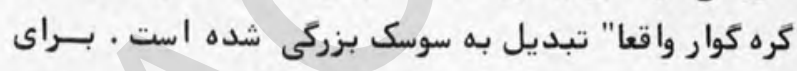

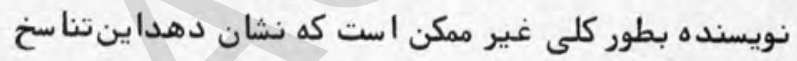

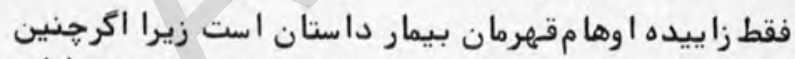

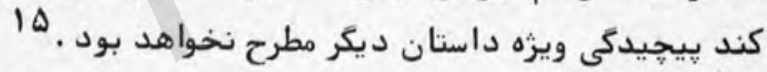

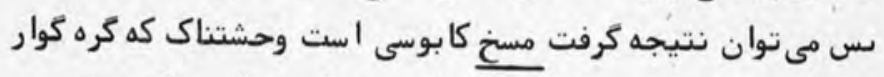

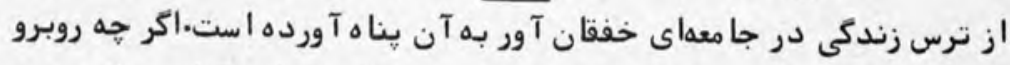

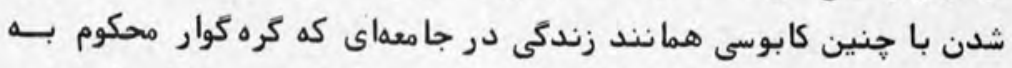

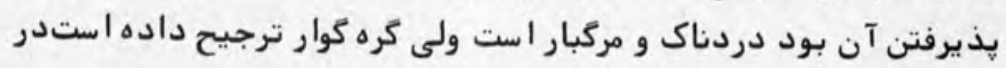

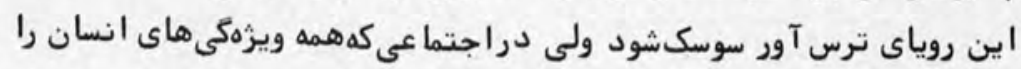

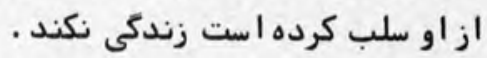

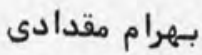


ا - فرانتسكافكا ، مسـخ ، ترجمه صادقهدايت (تـهران :انتشارات

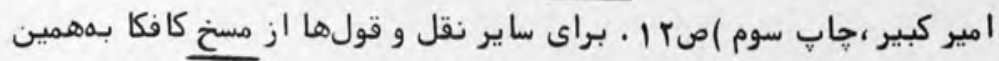
ترجمه مراجعه شود .

2- Johannes Pfeiffer, "The Metamorphoses",A Collection of Critical Essays on Kafka, ED. By. Ronald Gray(Enqlewood Cliffs: Prentice Hall INC., 1962), P. 53.

$$
\text { r r }
$$

4- Wilhelm Emrich, Franz Kafka, Trans. By Sheema Zeben Buehne ( New York: Frederick Ungar Publishing Co., 1968), P. 143.

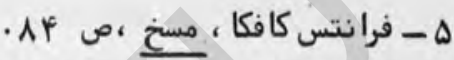

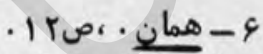

7- Charles Osborne, Kafka, (Edinburgh and London: Oliver and Boyd, LTD., 1967), P.40.

8- Norman O. Brown, Life Against Death, ( London: Sphere Books LTD., 1970), PP. $16-21$.

9- Wilhelm Emrich, Franz Kafka, P. 136.

10- Acquisitive

11- Helmut Richter, Franz Kafka-werk und Entwurf, ( Berlin: Ruetten und Loeing, 1962), S. 117 und 19.

$$
\text { r r r - همان }
$$

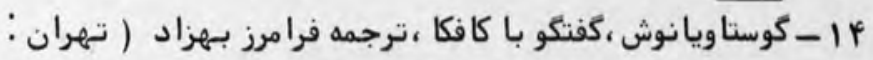

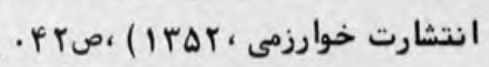

15- Friedrich Beissner, Der Erzähler Franz Kafka,(Stuttgart: Kohlhammer, 1952), S. 36 und 37. 


\section{زكته شنيدنى \\ از آغاز صنعت هاي در عثمانى}

ظهور انديشه هاى نو و در آمدن هنر ها و فنون تازه در جامعه ها

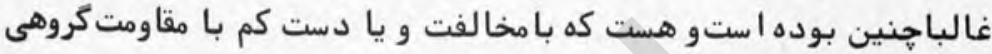

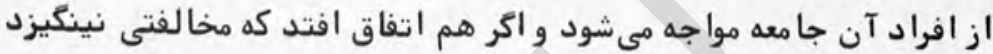

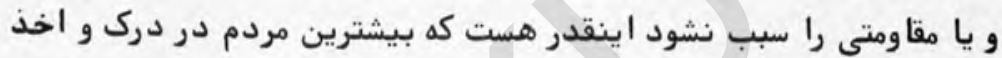

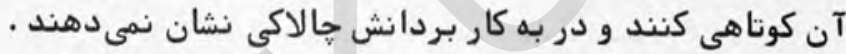

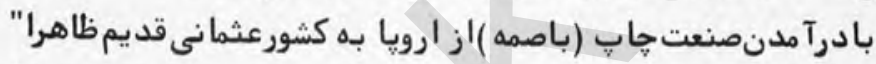

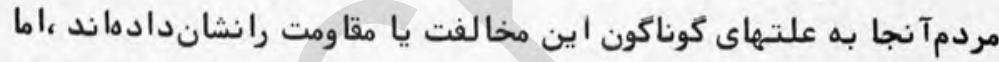

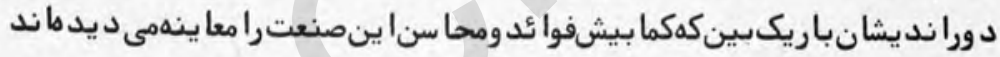

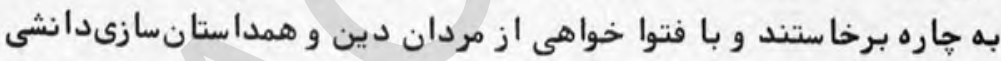

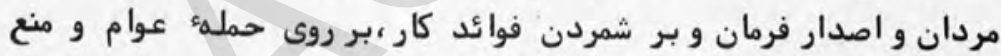

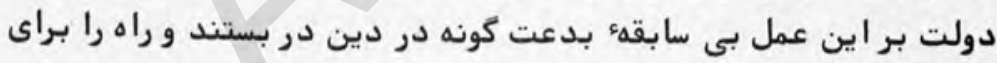

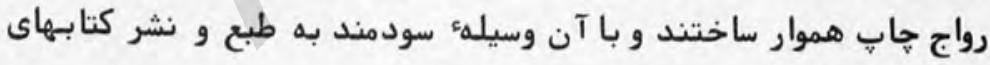

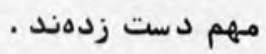

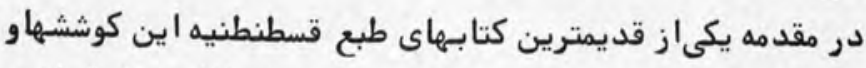

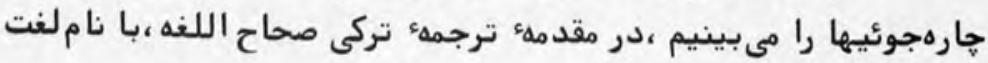

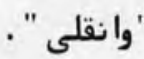

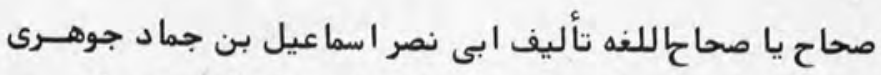

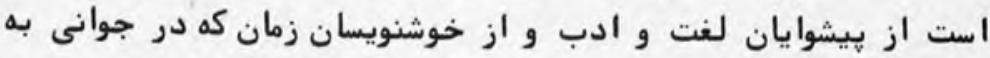

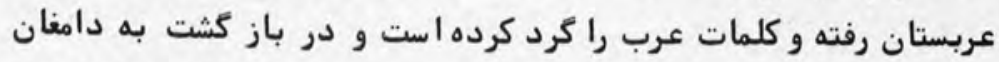

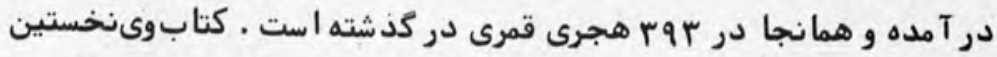

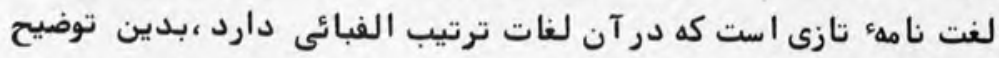




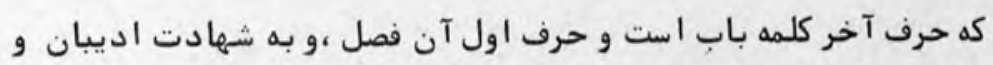

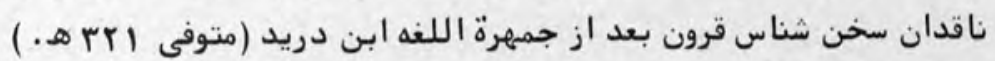

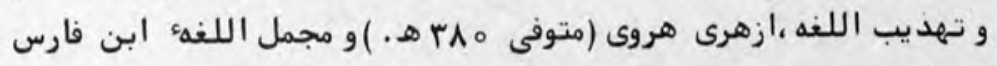

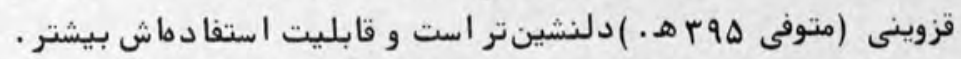

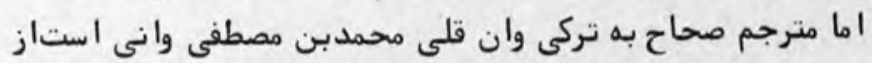

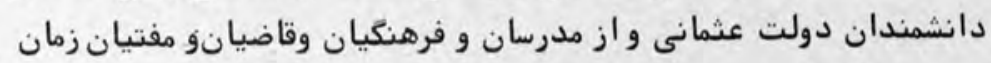

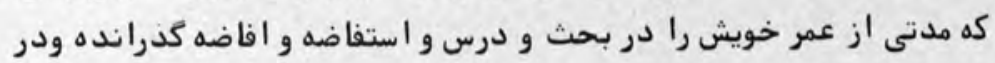

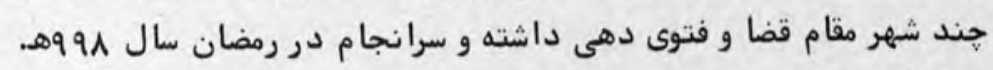

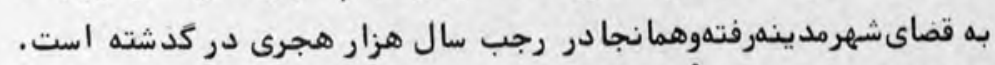

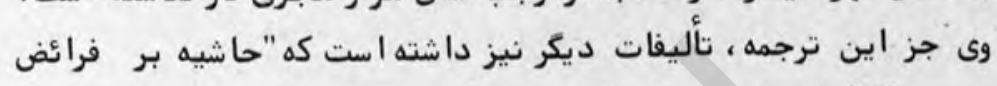

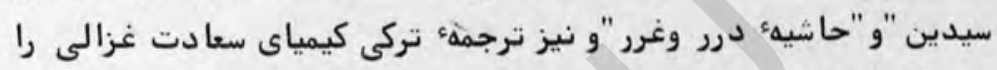

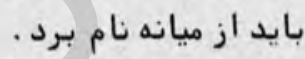

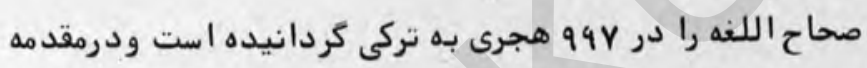

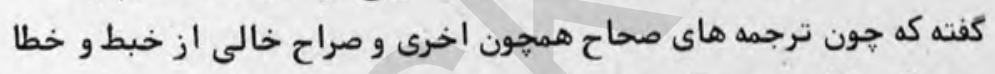

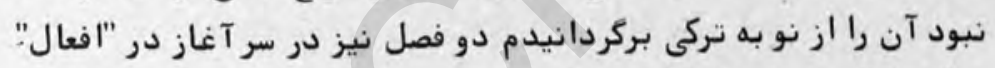

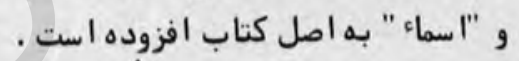

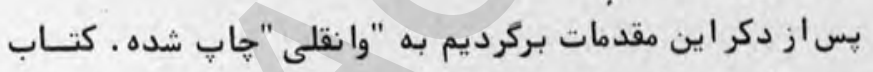

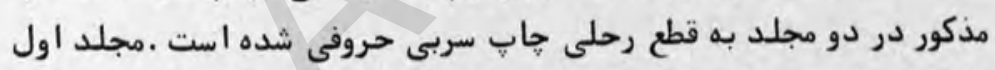

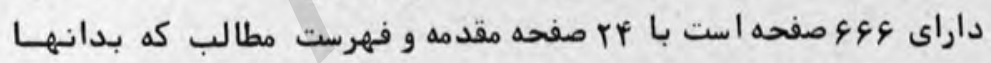

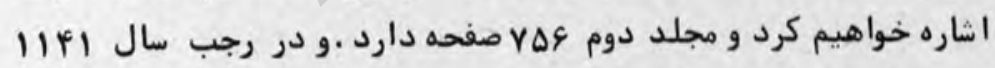

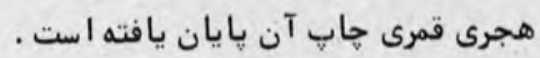

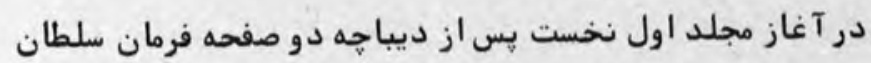

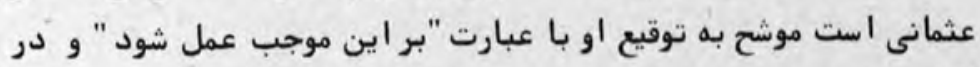

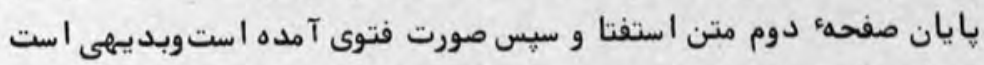

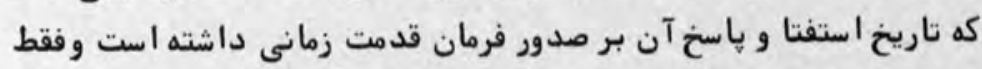

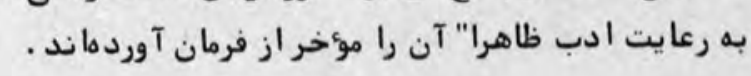


ساخت تا آن حد كه كتب مهم و مورد نياز علمى و ادبى و تاريخ سخت

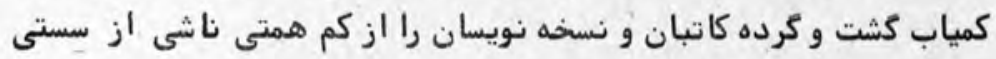

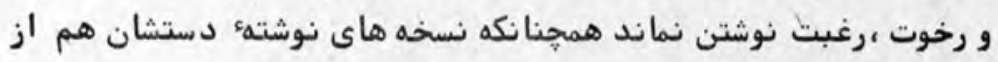

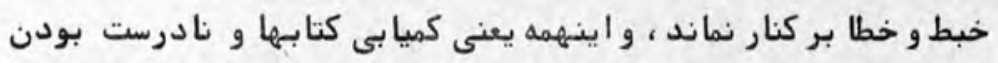

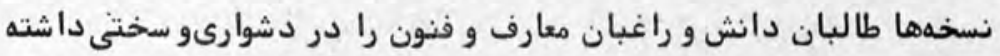

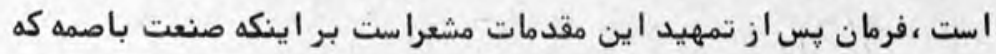

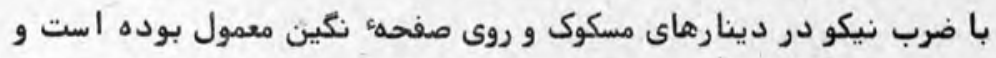

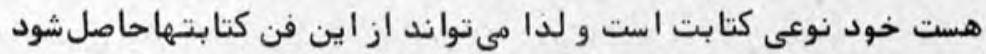

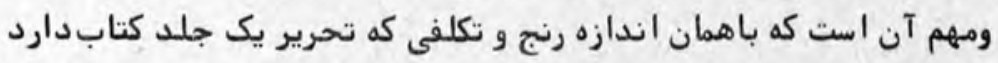

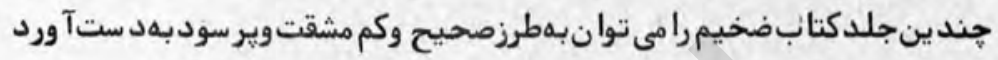

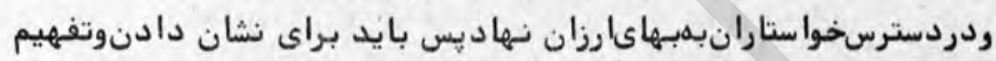

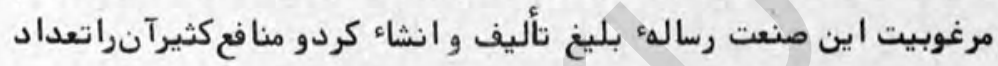

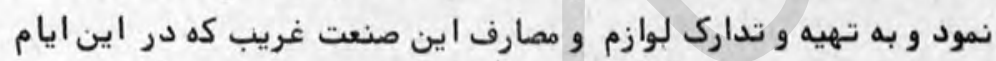

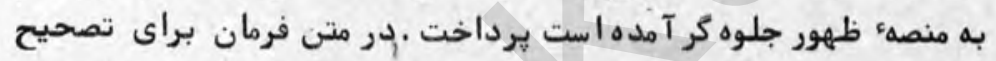

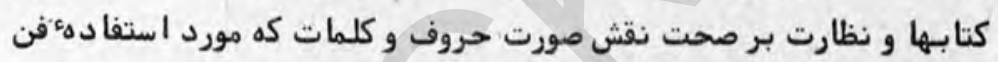

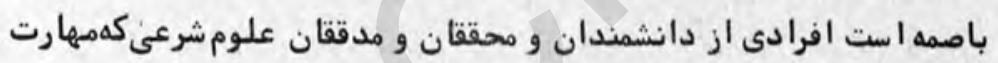

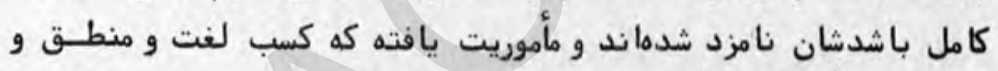

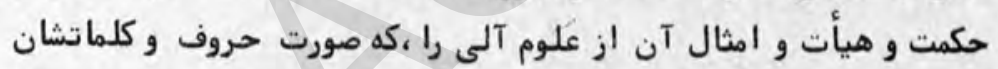

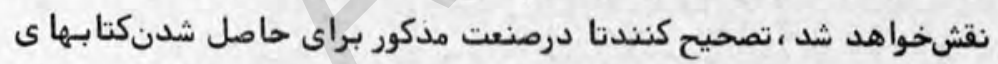

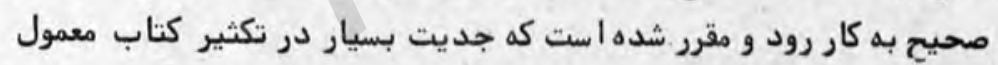

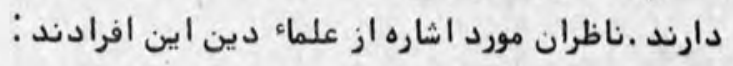

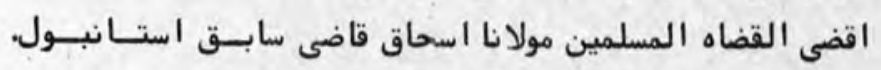

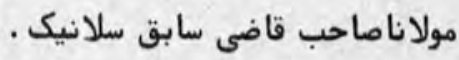

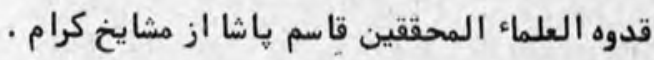
مولاناموسى شيخ مولوى خانه.

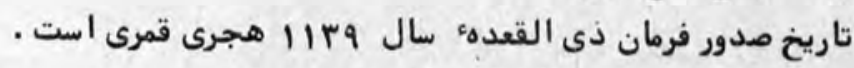

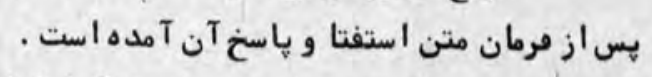

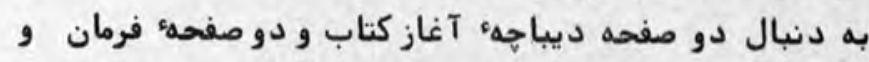

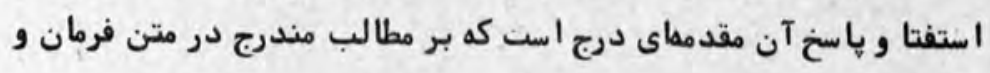


كتهء شنيدنى فتوى اشاره دارد و طابع توضيح مى دهد كه در اجراى آن نيت ون د دستور از

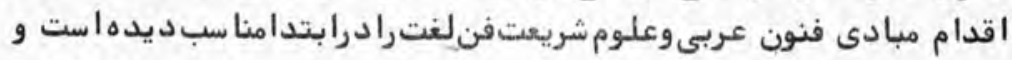

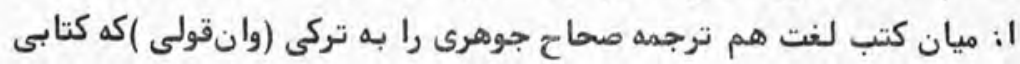

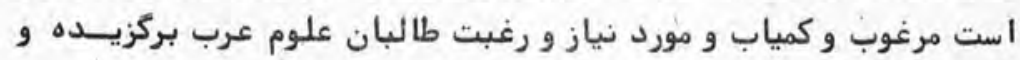

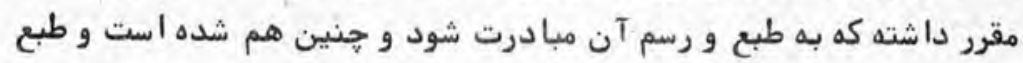
كتاب صورت اتمام يافته.

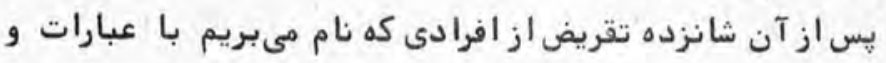

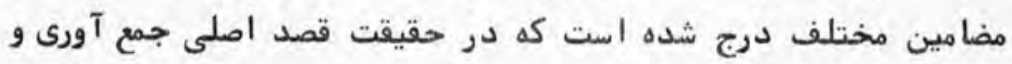

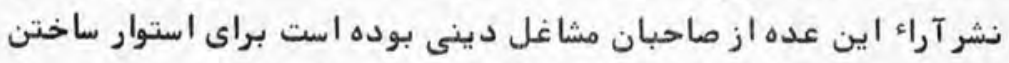

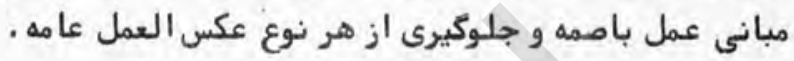
شيخ الاسلام عبدالله مفتى دولت عثل جثانى

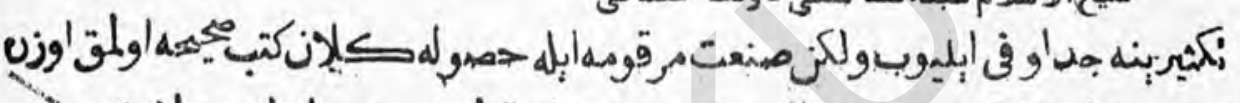

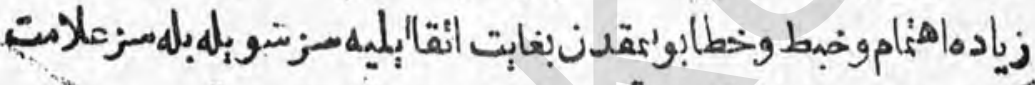

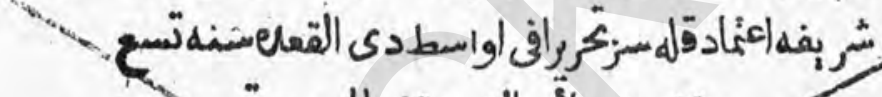

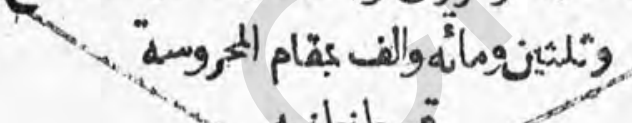

$$
\begin{aligned}
& \text { قصسطنطنه }
\end{aligned}
$$

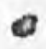

\section{هنs:}

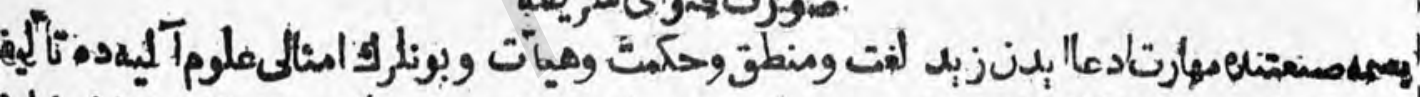

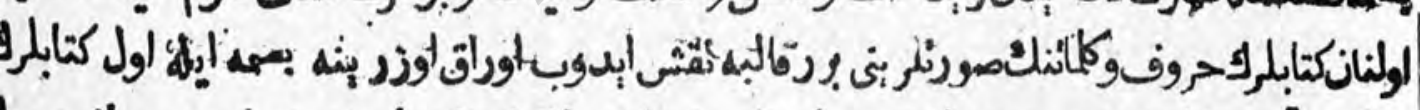

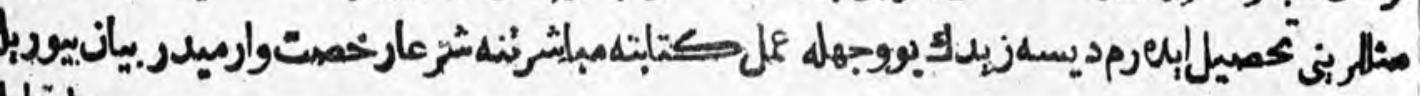
|läl

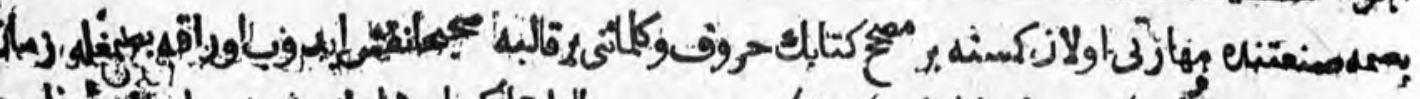

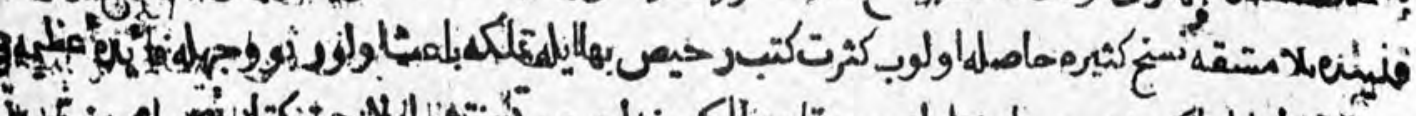
1

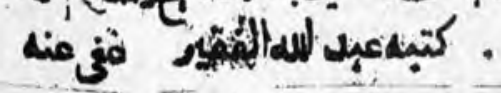

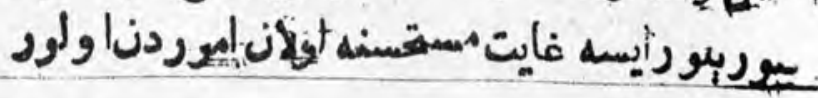


داماد زاده افندى صدر سابق روم

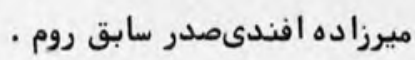

عبدالله افندى صدر سابق روم افندي

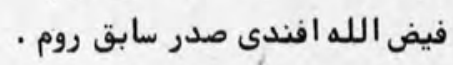

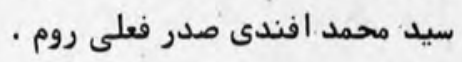

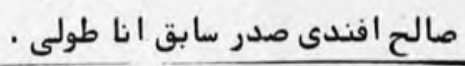

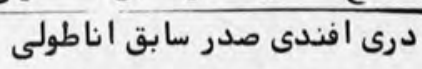
مصطفى افندى صدر اناطولى .

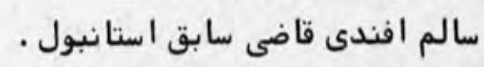

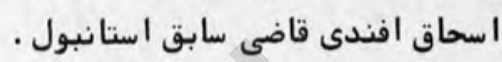

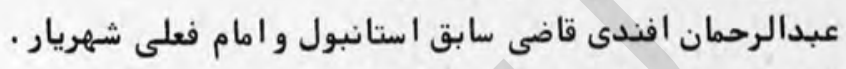

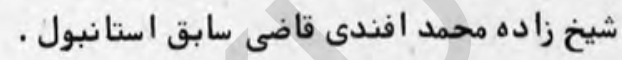

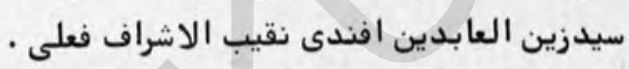
زلالى افندى قاضى سابق استانبول .

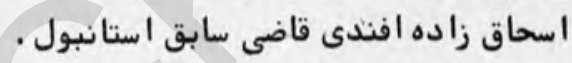

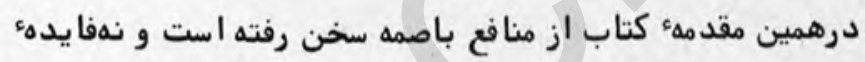

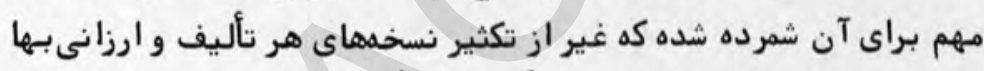

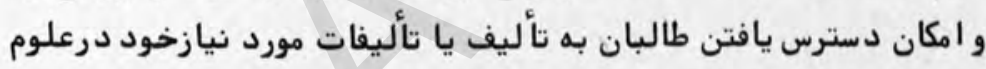

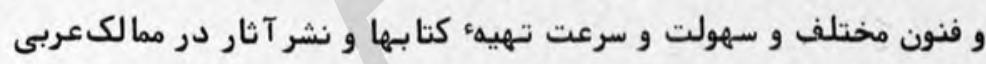

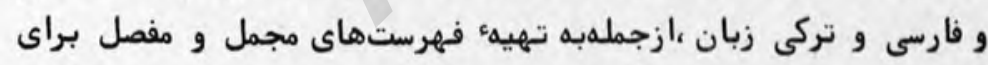

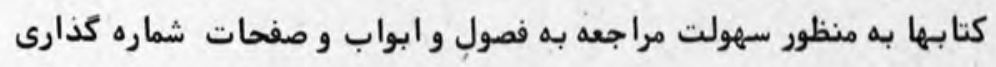

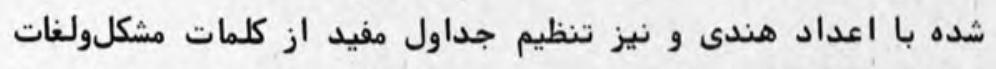

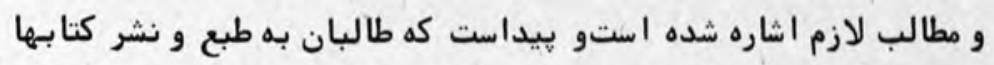

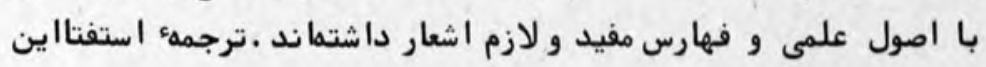

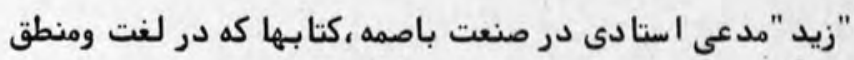

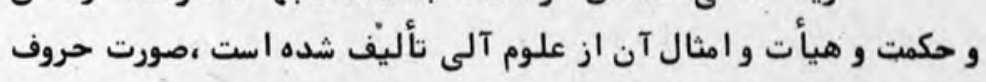

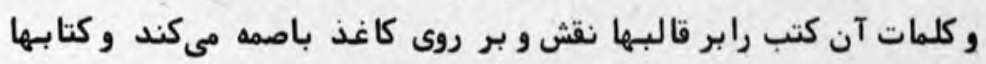


نظير نسخهء نخستين به دست مى آورد .در مباشرت زيد بروجه فوق بهعمل كتابت شرعا" اجازه و رخصت دارم يا خير؟ بيان فرمائيد.

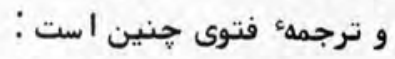

الله اعلم .كسى كه در صنعت باصمه استادى دارد و حسـروف و و

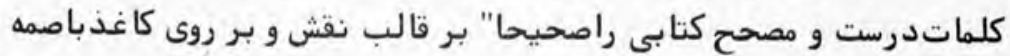

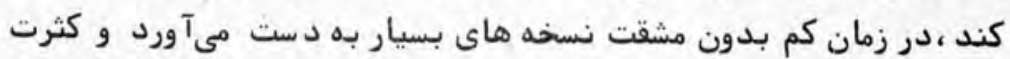

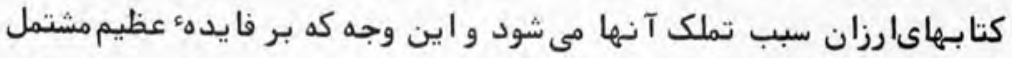

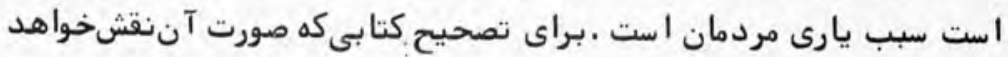

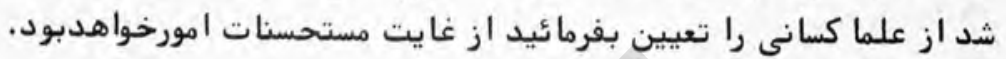

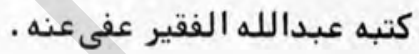

\section{*米米}

درايران رواج صنعت هاب و فن طبع خوشبختانه با مقا ومتى مواجه نكشته است واز همان آغاز كار نيز بدان اعتبار و توجه كردها ندو وائ واين شايد

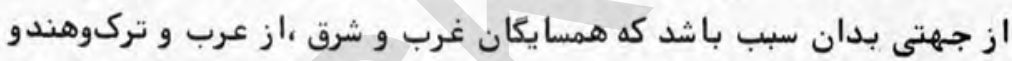

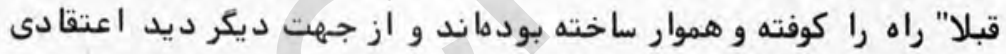

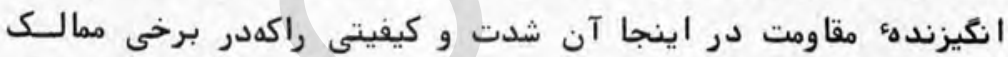

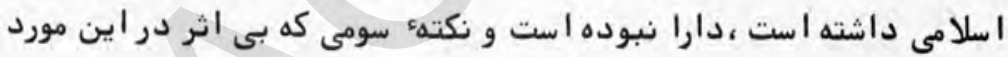

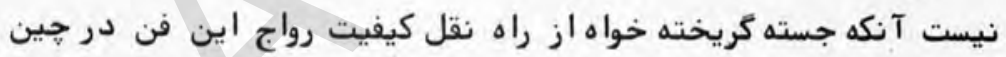
و خواه بسبب مباشرت به خود صنعت در دوران صفويه ، توسط كشيشان مقيم

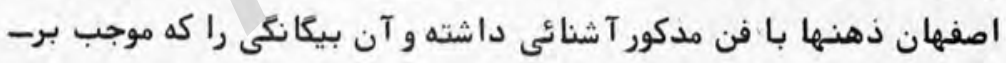

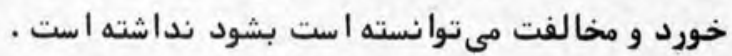

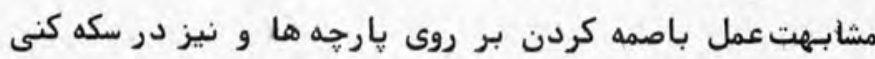

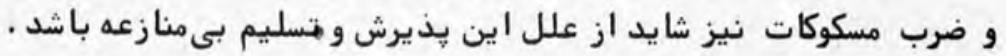

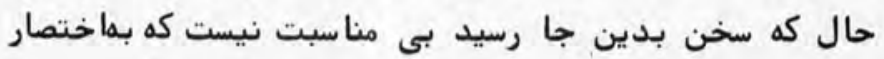

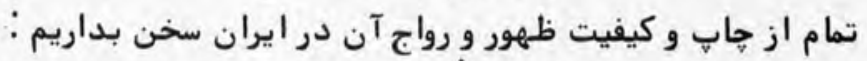

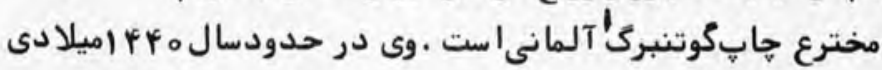

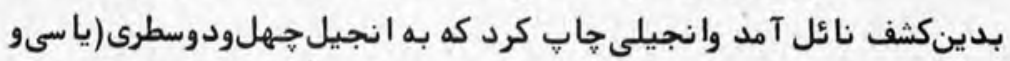

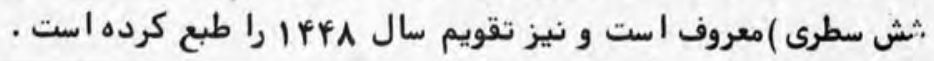

1-Johannes Gutenberg. 
امارواج صنعت حاب در هين قديمتر از اين است وبه عبارت بهـتر

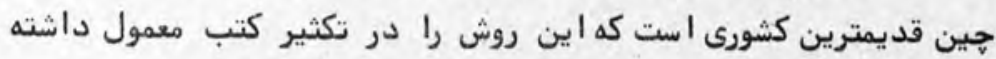

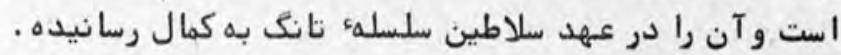

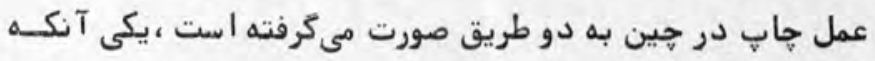

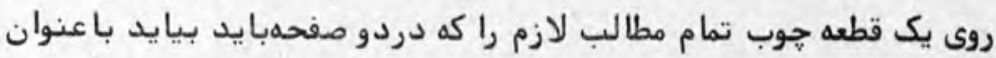

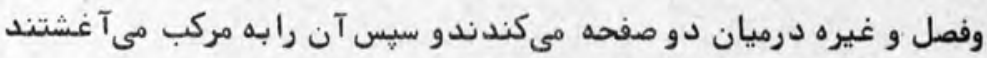

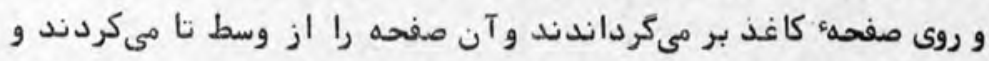

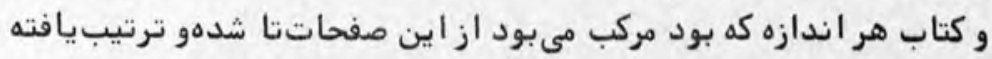

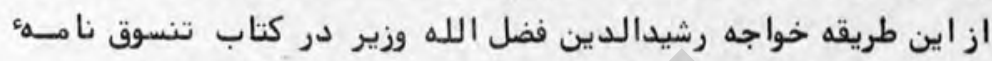

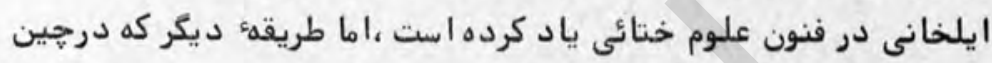

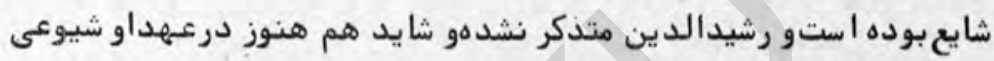

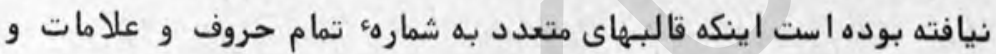

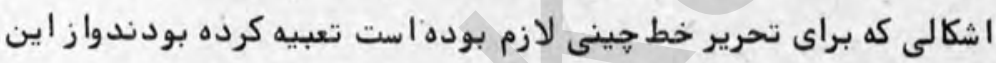

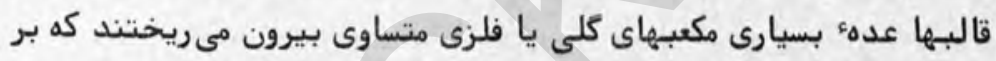

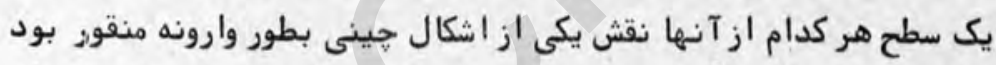

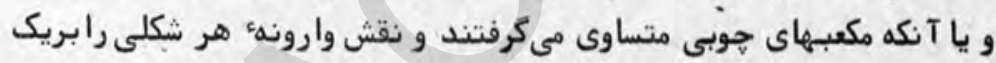

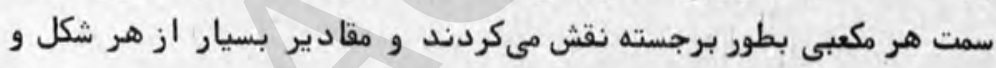

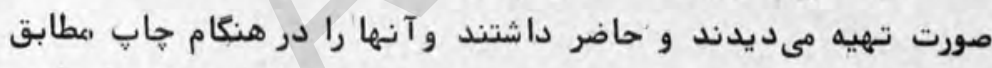

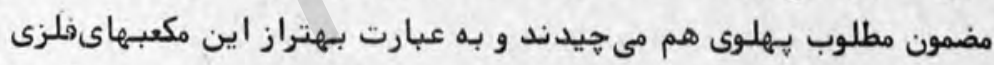

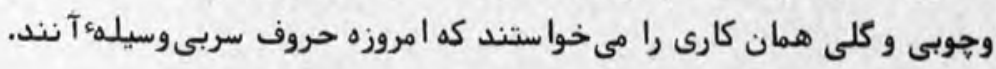

\section{米米米}

براى اين عمل ،يعنى تهيهء نوشته بر روى صفحات به تعداد برسيار

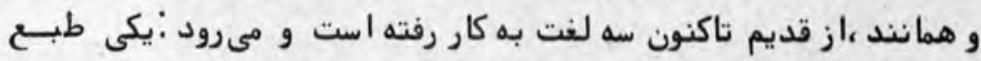

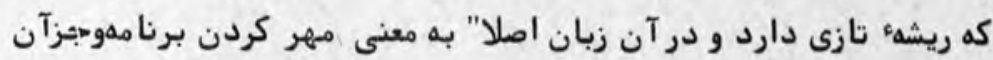

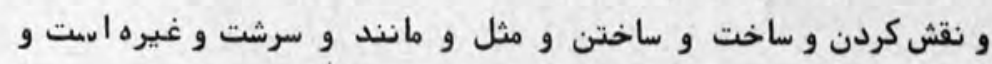

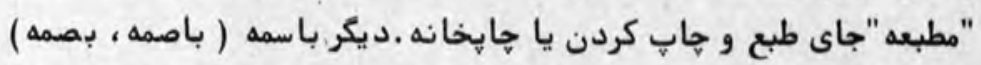

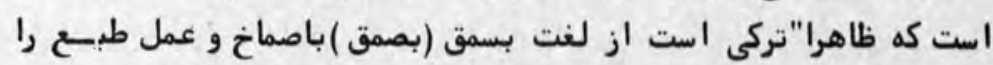

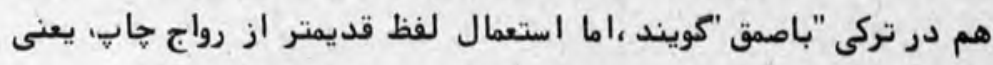


ror

باصمه درعثمانى است ،در ايام مغول اين كلمه رايج بوده وتصويرشاهان

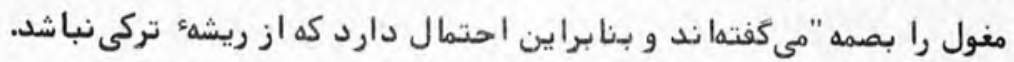

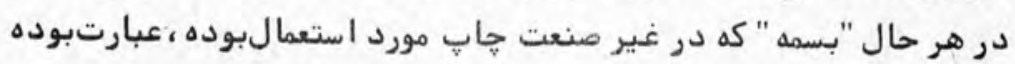

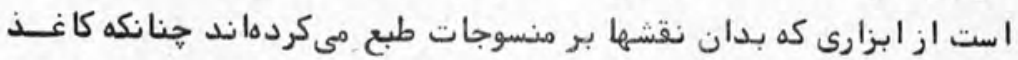

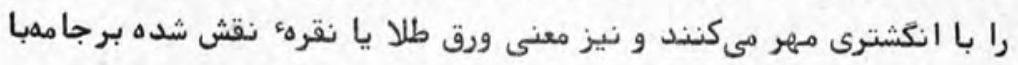

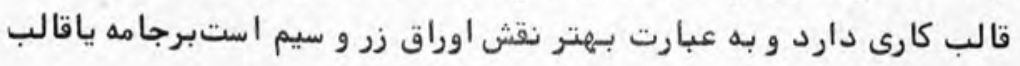

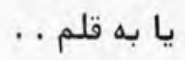

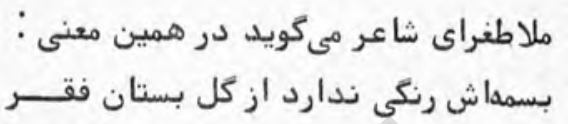

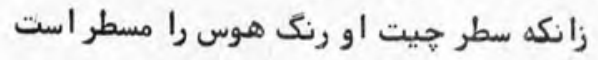

اماظاهرا" اطلاق "باسمه "بر صنعت حاب و "باسمهخانه "برحا هايخانه

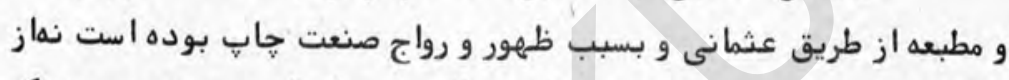

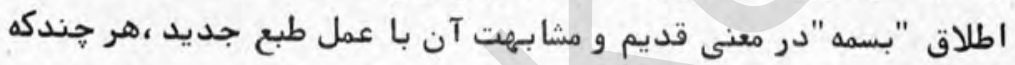

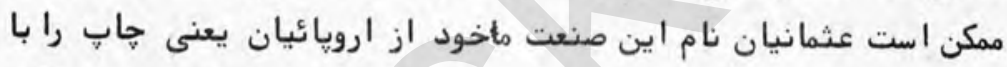

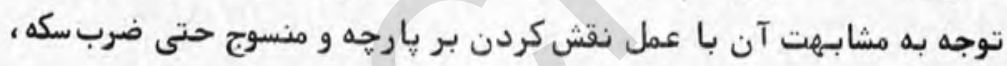

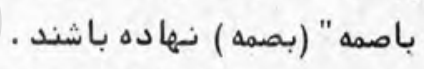

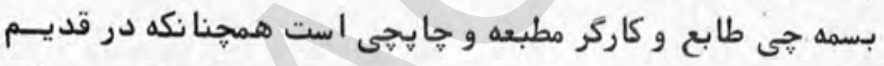

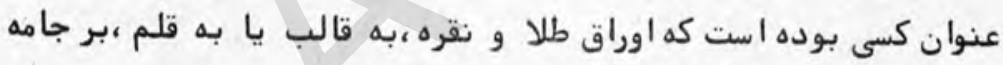

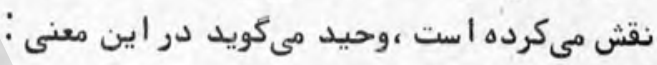

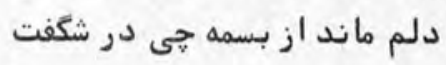

ازو ديدهام نقش حيرت كـرفت

(شعر ملاطغرا را هم فرهنك بهار عجم به شاهد بسمه جيى آورده

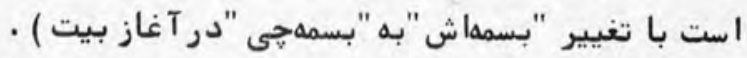

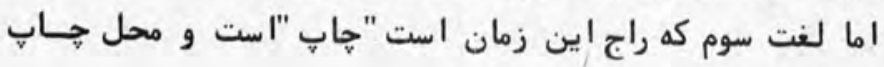

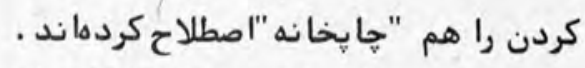
اين لغت را مرحوم اقبال آشتيانى از كلمهء جاو "داند "دانسته است كه

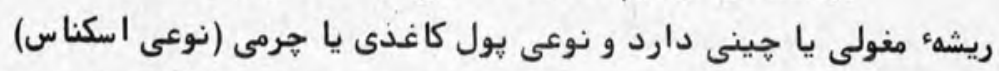

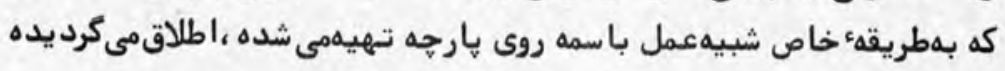


است .در هندىهمين عمل را "جهاب "و "جها هِه "مىكويند وآن در اصل به

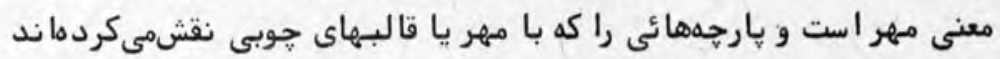

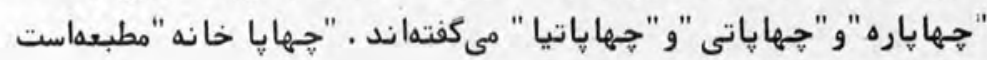

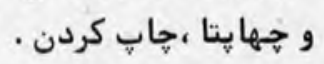

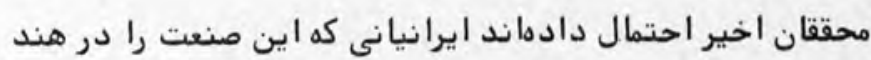

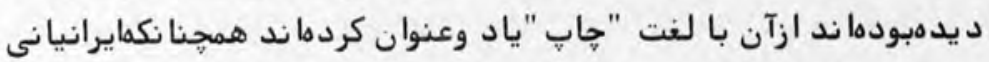

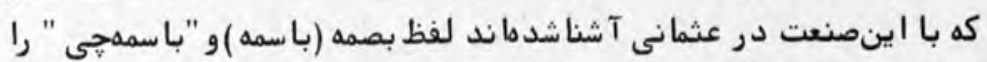

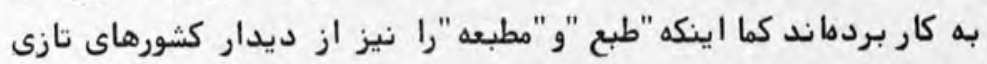
زبان هون مصر و عراق و غيره كرفتها ند .

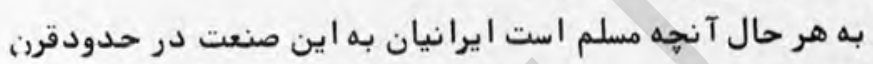

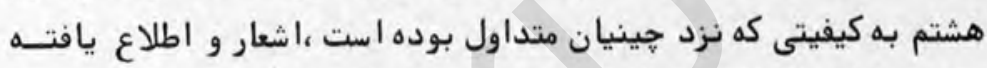

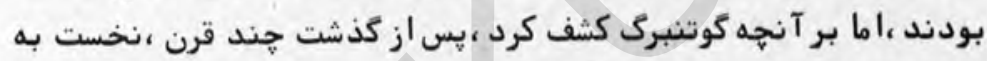

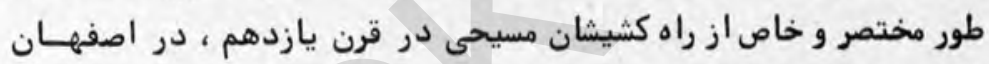

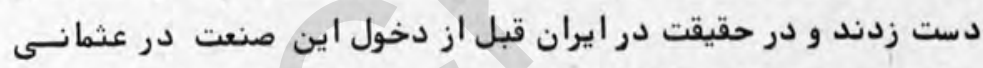

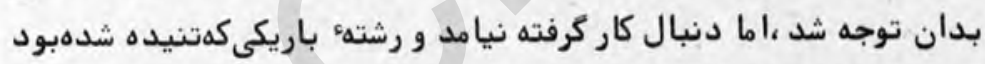

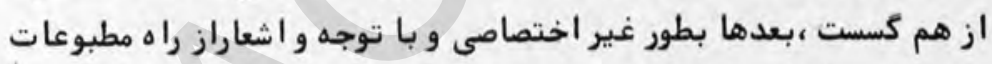

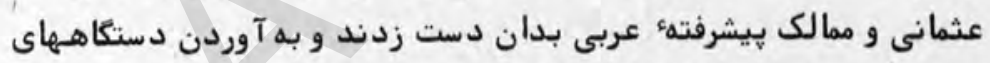

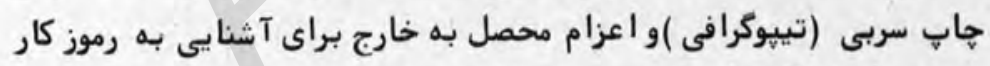

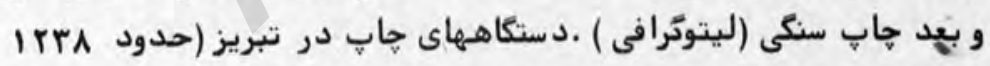

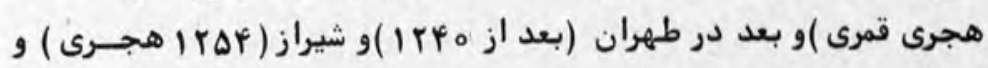

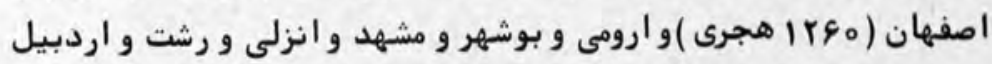

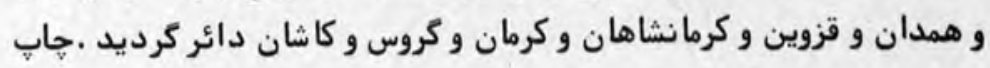

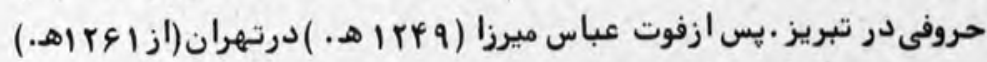

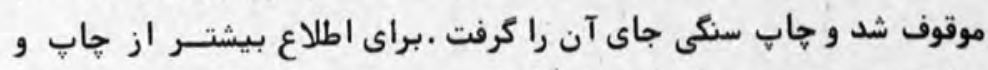

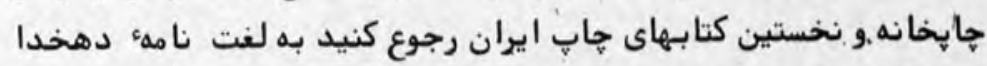
ذيل لغت جاب و مآخذ مذكور در آن كتاب .

محمد دبير سياقى 


\section{||}

ته كلاس ا يستاده بودم ،و به انشاى بحهمها كوش مى دادم . اغلب

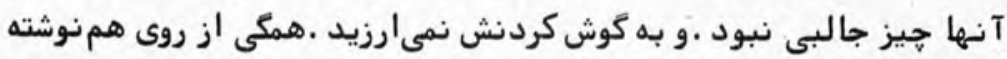

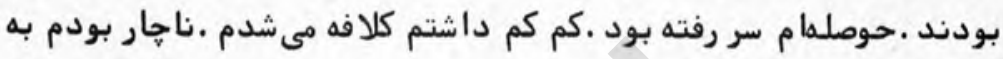

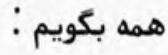

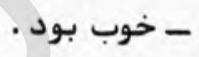

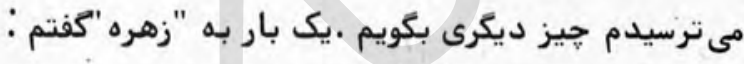

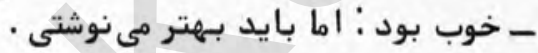

$$
\begin{aligned}
& \text { كفت : }
\end{aligned}
$$

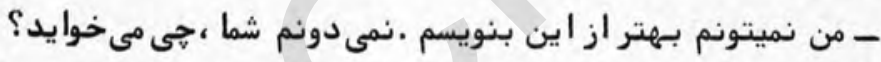

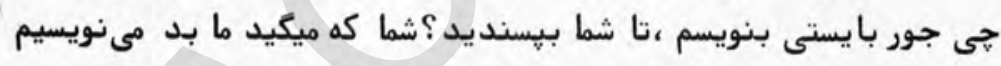

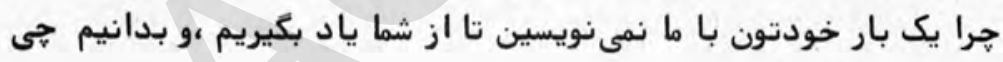

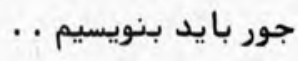

بحهها به هيجان آ مدند و دست زدند .از كوشهى حشم به منخيره

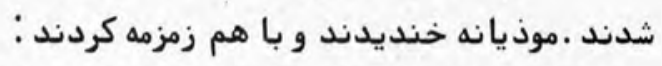

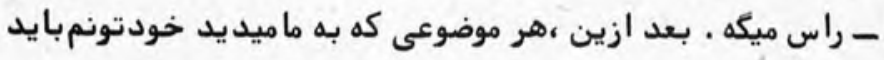

بنويسين .

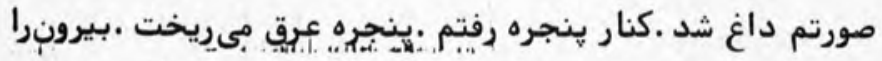

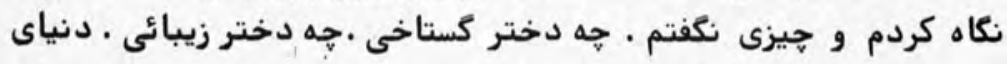

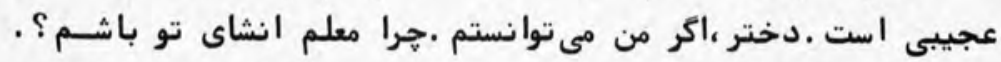

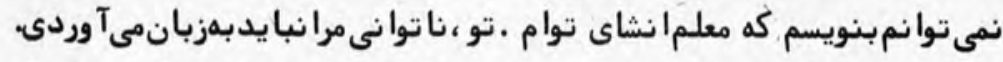

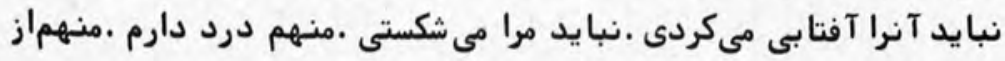




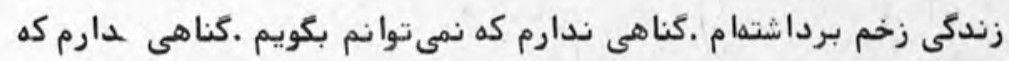

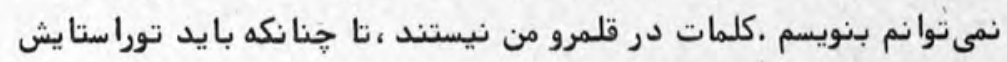

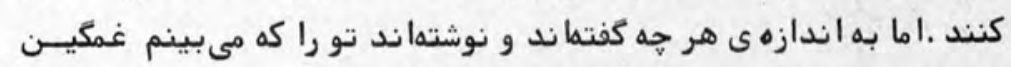

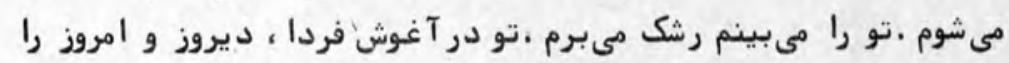

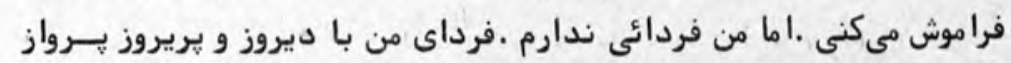

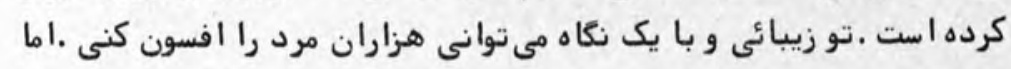

مستخدم دبيرستان در كلاس را باز كرد و كفت :

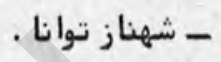

$$
\text { - بله. }
$$

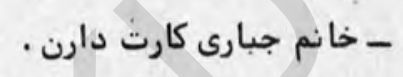

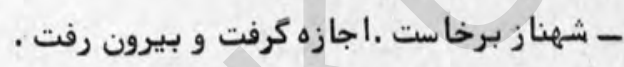

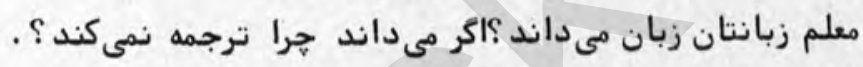

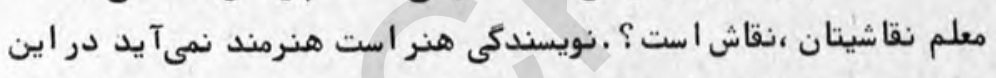

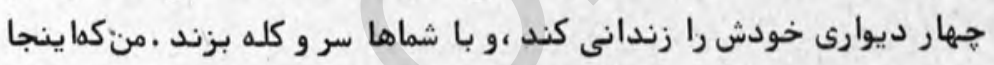

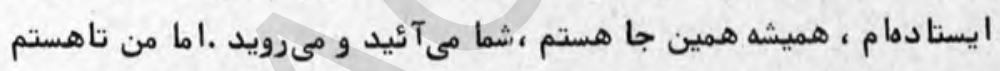

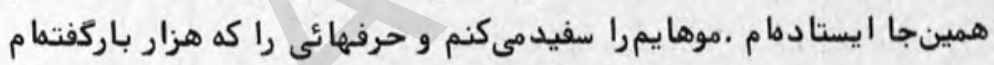

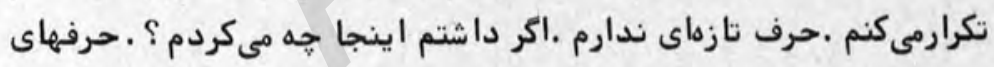

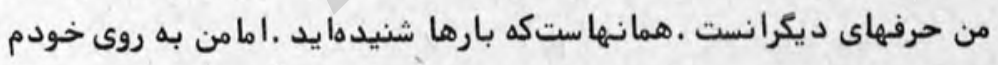

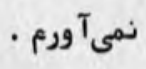

سنكين قدم بر مى دارم و شمرده شمرده مىكويم :

ـ در كذشته هيج كار نكرديد .

$$
\text { شما مىكوئيد : }
$$

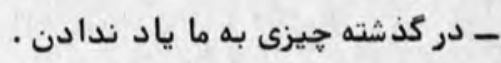

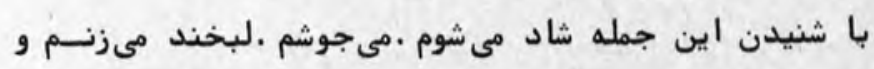
مى :

- راست ميكيد .شما كناهى نداريد .

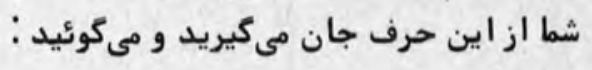


- خوب درس نمى دادن .جيزى بلد نبودن .كلاسشان خستهكننده بود .بحمها شلوغ ميكردند . باز مىشوم و يرواز مىكنم .خودم را و ناتوانيم را فراموشمى شكنم.

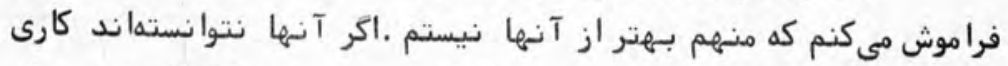

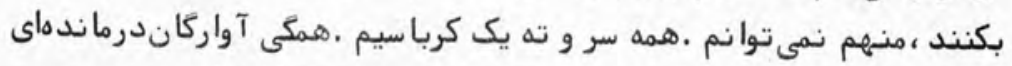

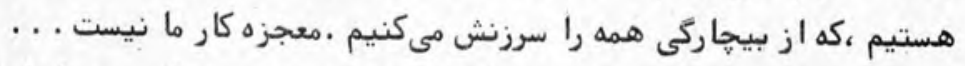

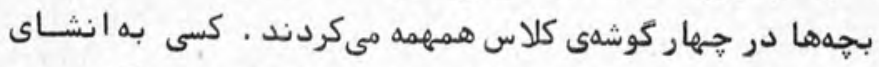

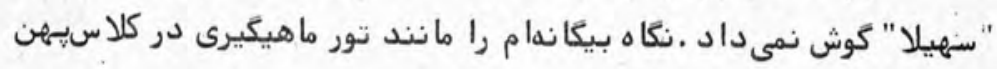

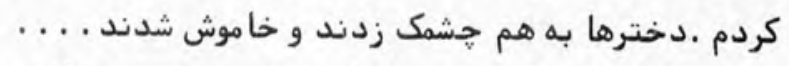
شهناز بركشته بود .اجازه كرفت و رفت سرجا يش نشست .

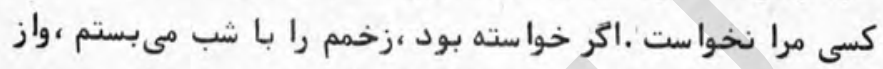
اين تاريكى بيرون مى آ مدم .بسكه با خودم بودهام از خودم بيزارم . .. . .

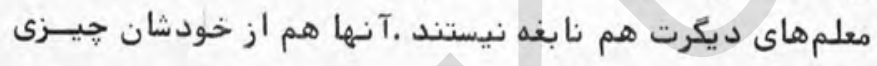

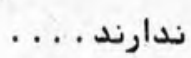

بحهما آرام نشسته بودند .ذهنم از حرف و جوانه سرشار بود.

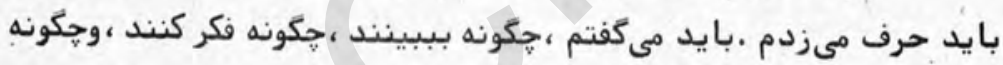

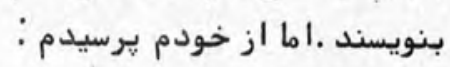

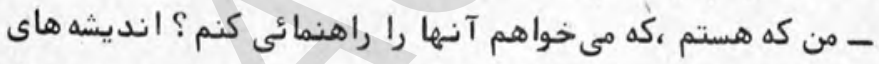

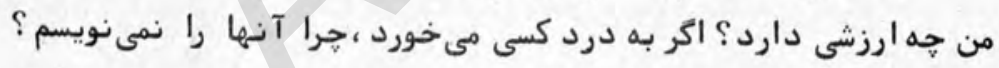

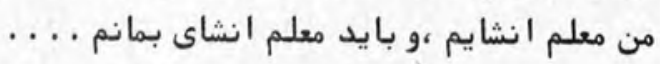

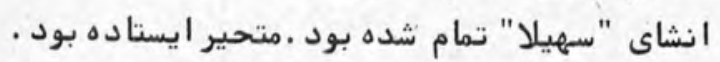

$$
\text { - خوب بود . }
$$

و رفتم روى صندليم نشستم .

تههران - خرداد ع rarg

عباس حكيم 


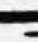 \\ هدفهاى فرهنغى زبان آموزى}

(2)

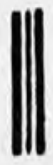

همه آنا نكه دست اندر كار تدريس زبانند مى دانند كه آموزشزبان

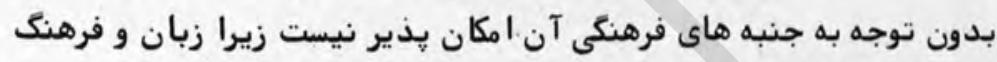

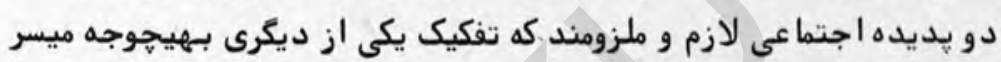
نمى باشد.

مقدمنا" بهتر است كه مراد از وازه "فرهنك "تصريح كردد . تا قبل

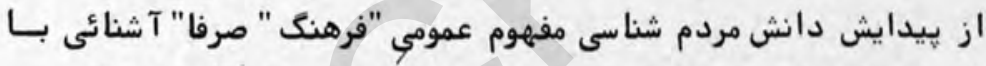

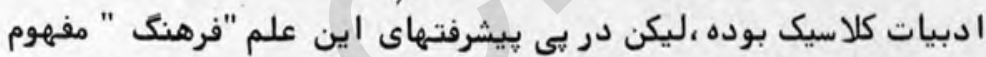

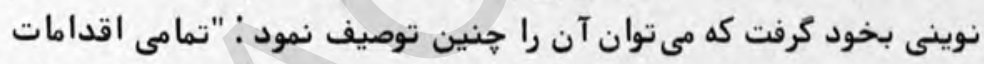

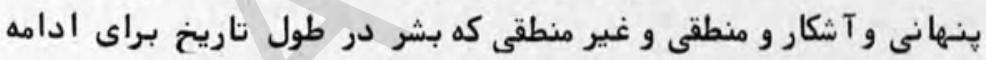

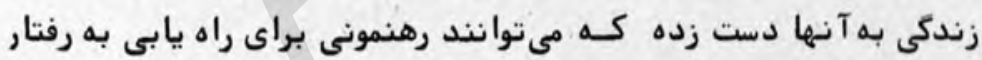

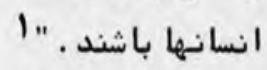

' آنا نكه هنوز به تعريف قديمى "فرهنك "ياى بندند حتى به هنكام

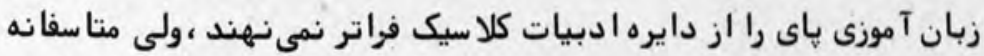

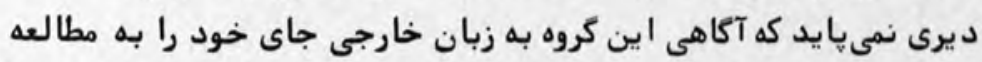

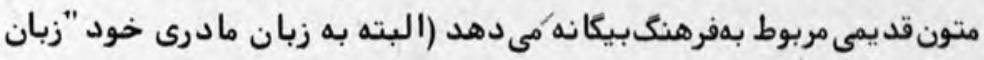

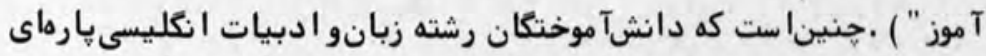

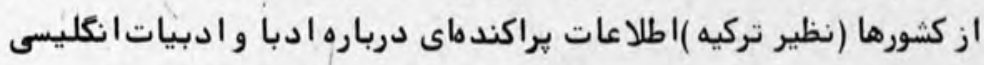

1- Harry Hoijer, "The Relation of Language to culture," in Anthropology Today, ed. A.L. Kroeber, (Ghicago: Univ. Chi. Press, 1953. P. 554. 


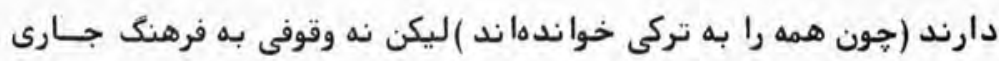

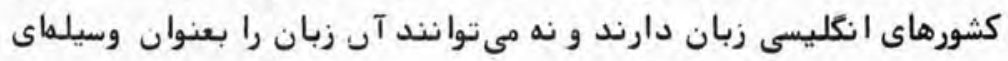
براى تفهيم و تفاهسم بكار برند ندان

با توجه به همين تفكيك نا يذ يرى فرهنك و زبان است كه مدرسين

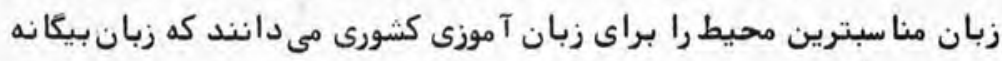

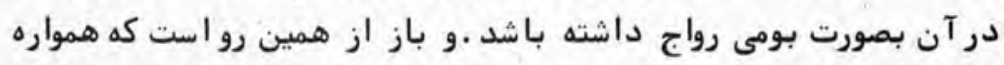

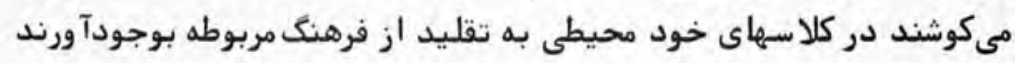

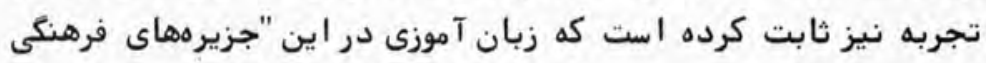

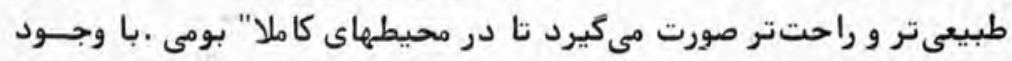

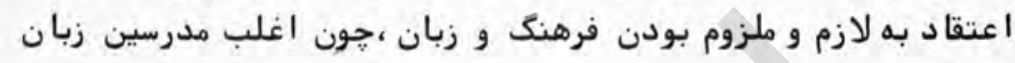

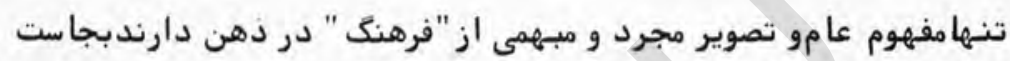

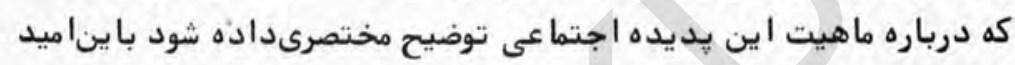

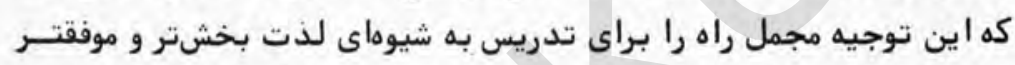

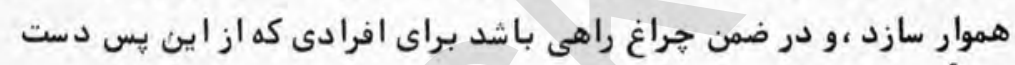

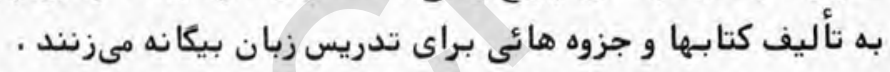

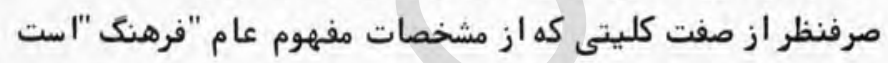

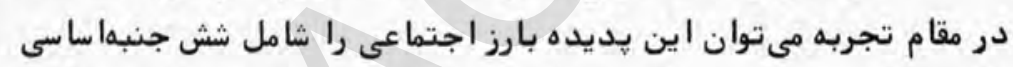

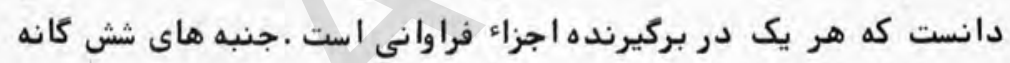

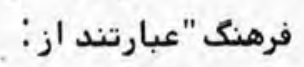

- - 1

نخستين كام آموزش زبان آكاه ساختن زبان آموز به اين حقيقت

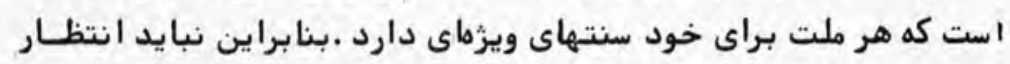

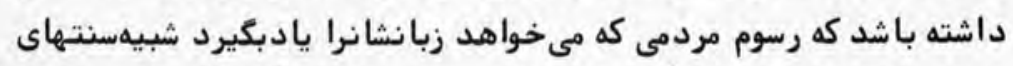

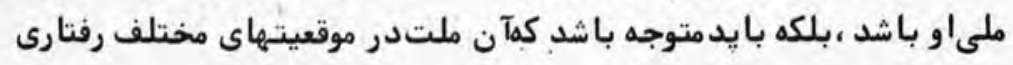

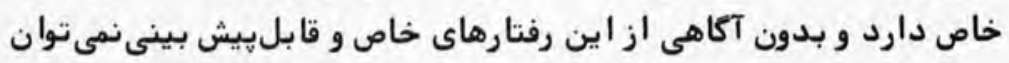

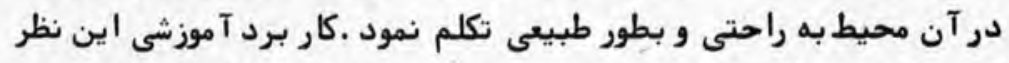

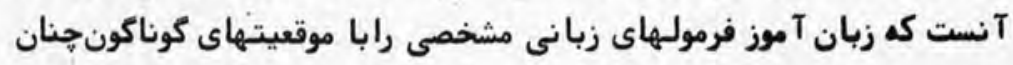

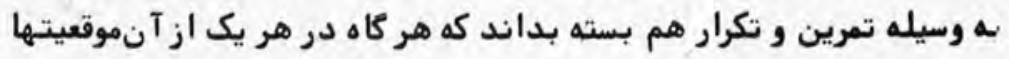


قرار كرفت بتوا ند بى درنك واكنشهاى كفنارى مناسبى را ارائه دهد . براى

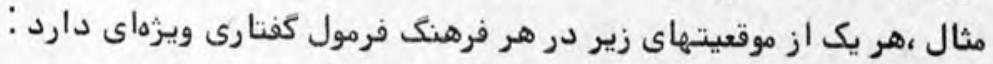

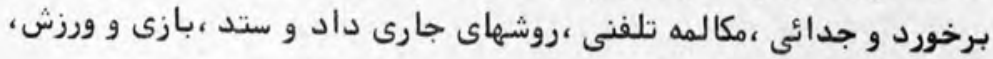

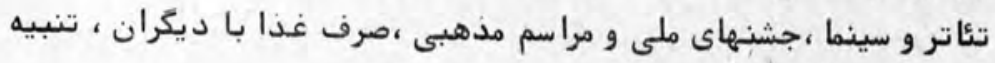

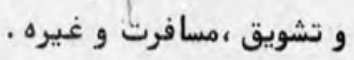

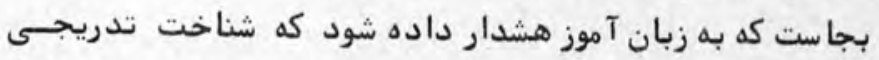

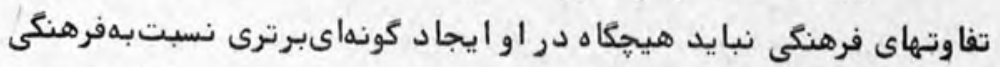

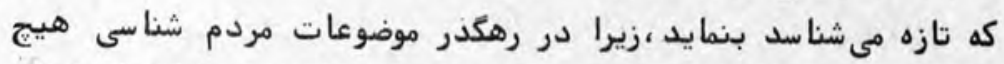

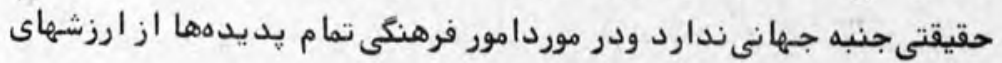
نسبى بر خوردارند.

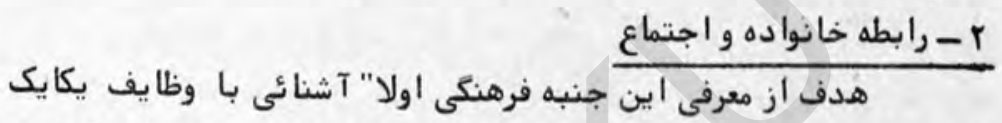

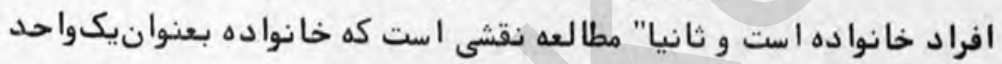

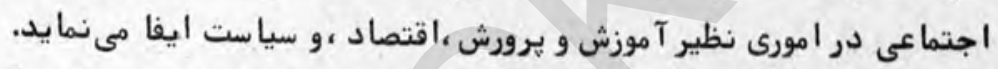

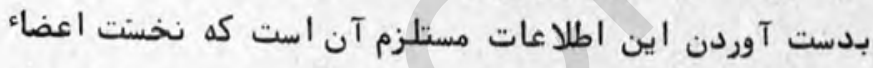

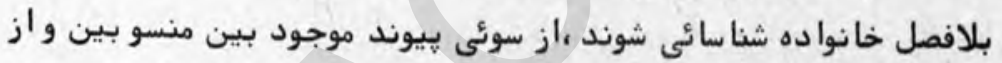

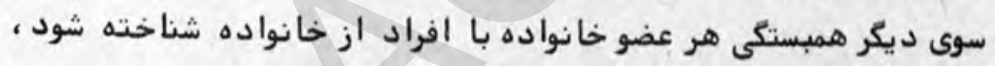

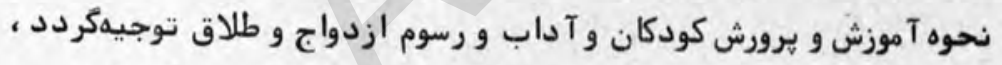

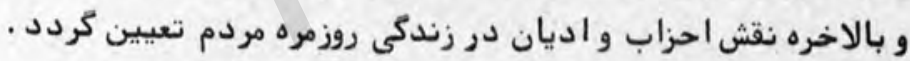

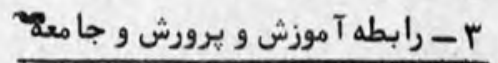

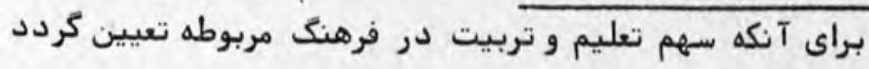
بايد به جنين موضوعاتى اشاره نمود :

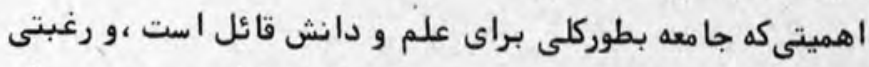

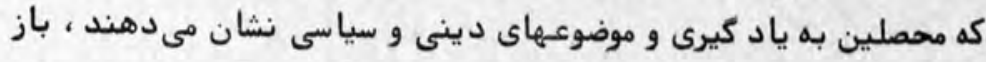
تاب سياست و مذهب در امر آموزش و برورش ،كيفيت كفت و و شنود دود بيني

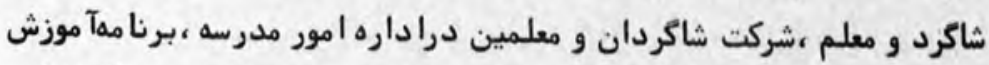

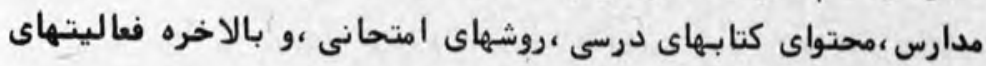

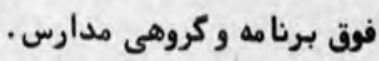




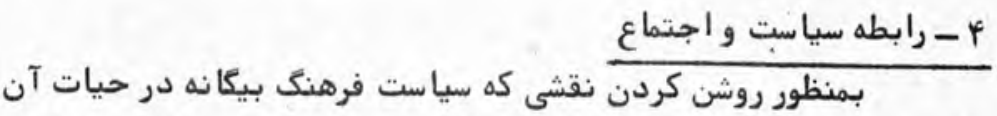

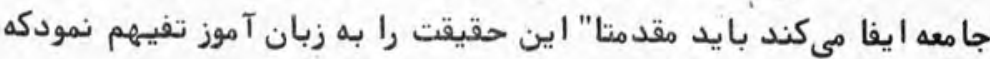

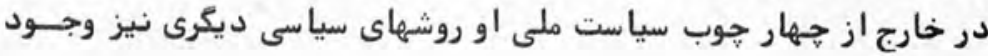
دارد .

شناسائى كارآئى نظاهماى سياسى كوناكون و آشنائى با مسائـل

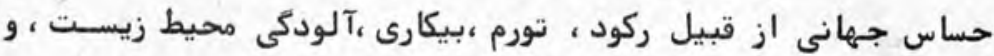

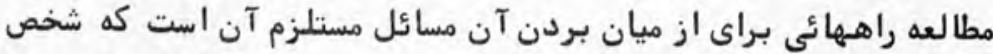

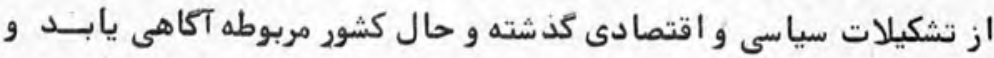

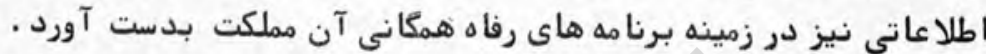

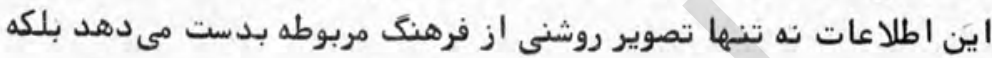

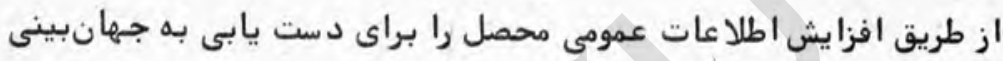
كسترده ترى يارى مىكند .

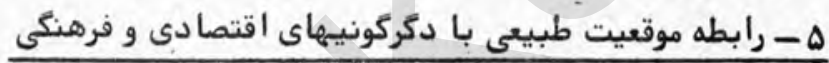

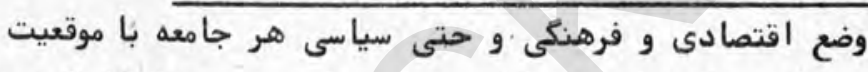

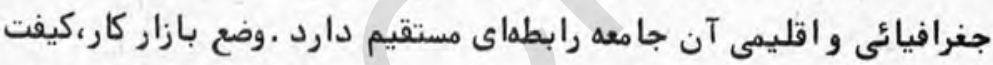

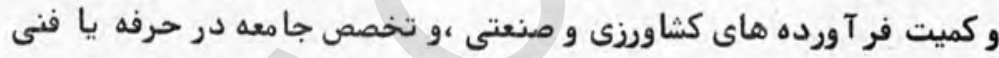

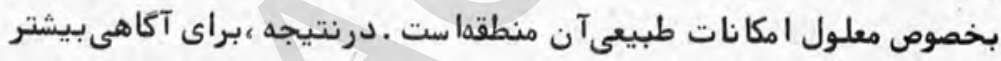

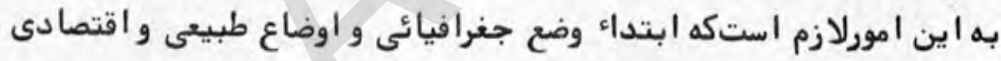

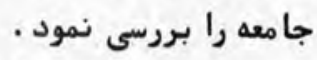

زبان آموز با آكاهى بـهـ مسائل ياد شده با علاقه و روشن بينسى

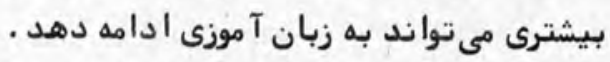

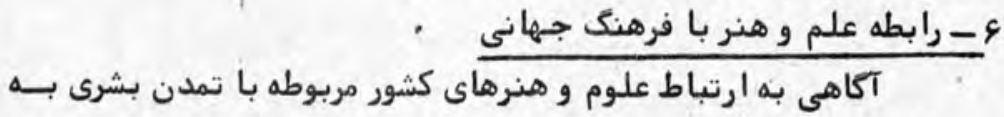

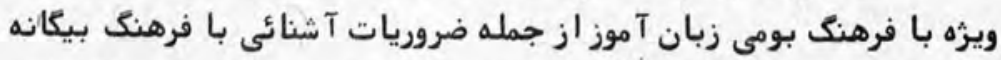

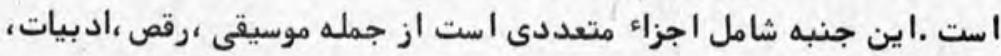

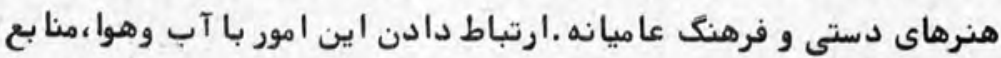

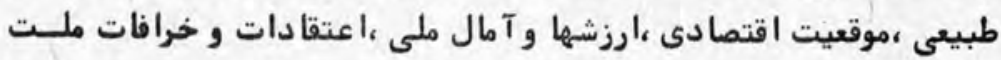


مربوطه اركان مهم آشنائى با فرهنك بيكانه را تشكيل مى دهد .

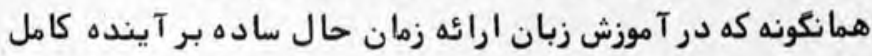

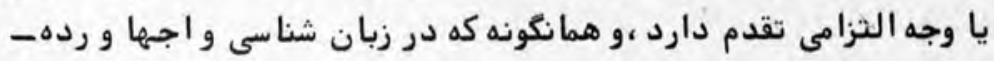

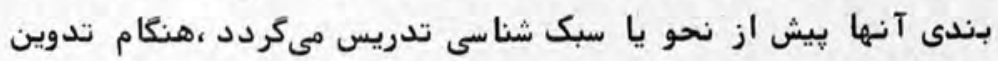

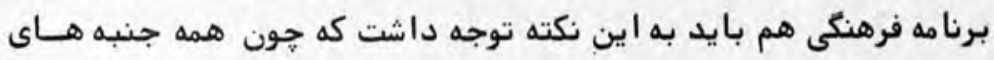

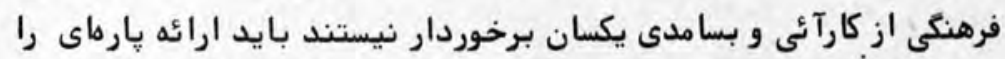

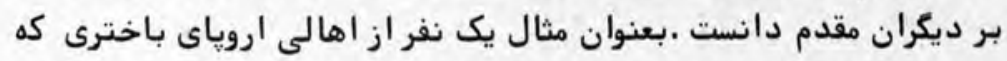

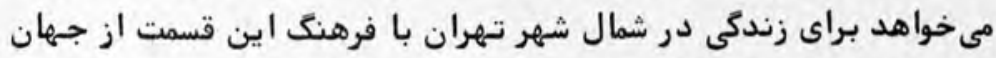

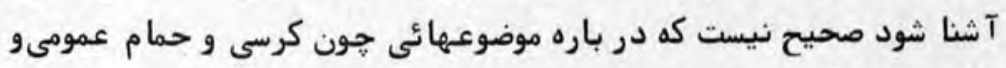

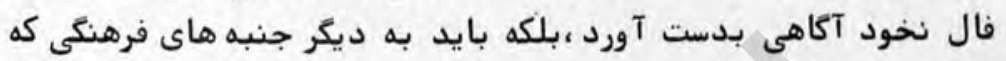

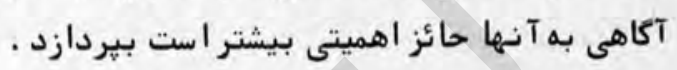

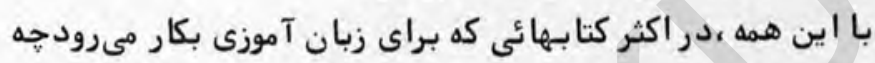

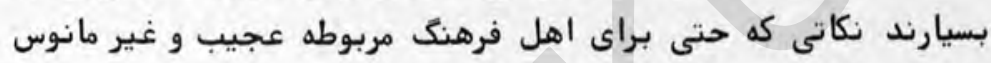

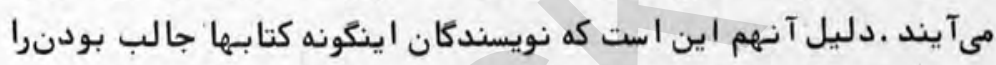

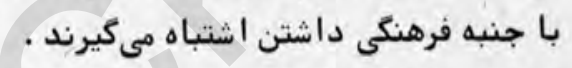

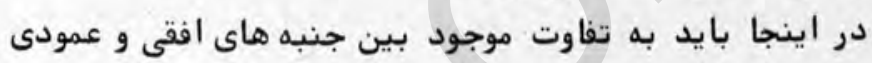

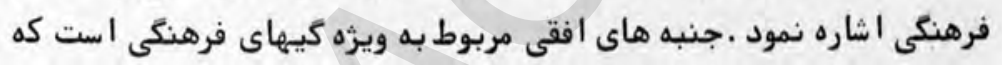

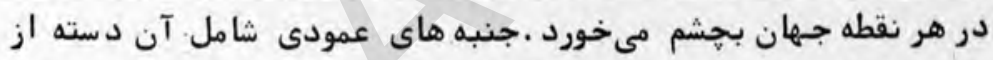

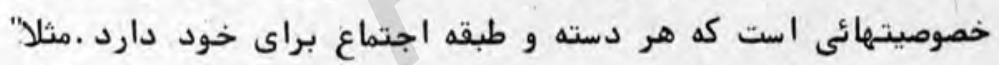

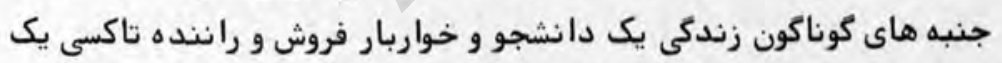

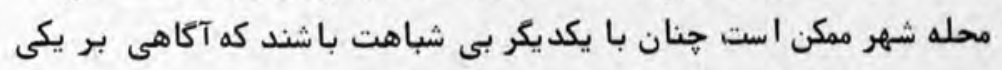

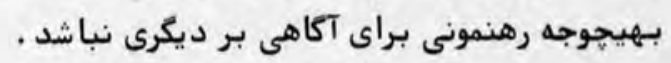

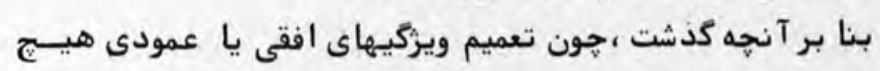

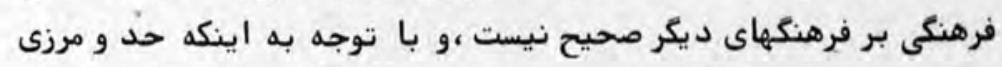

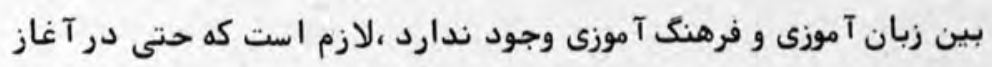

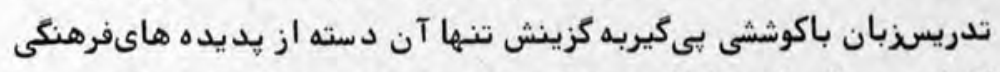

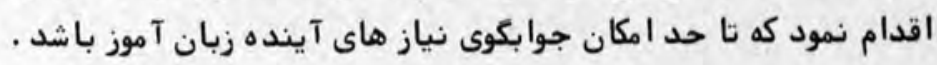

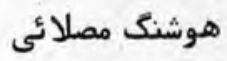


تقديم به استادم :ا _ داوران

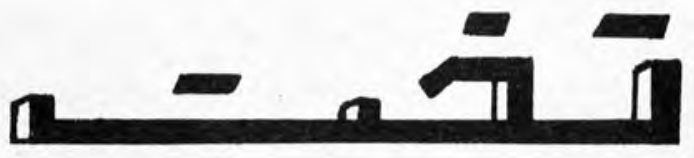

هوا كاملا" تاريك بود و از يشت شيشه ها ماه با حشمياى كشاد باو

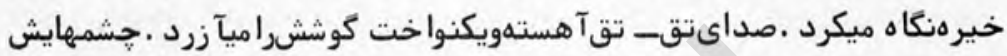

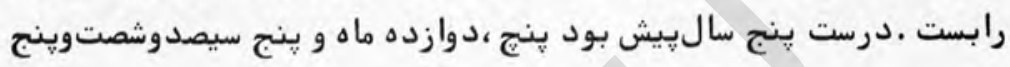

آنروز مادرش آن اطاق را نشان داده بود و كفته بود نه تنهها از

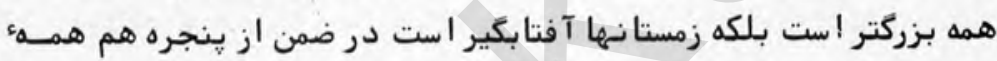

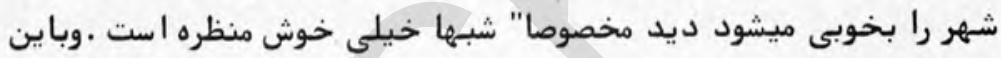

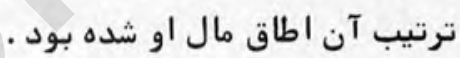

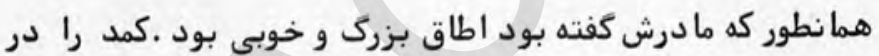

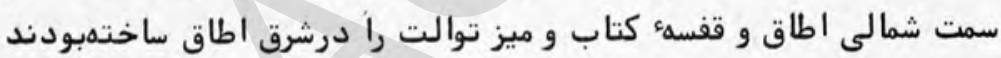

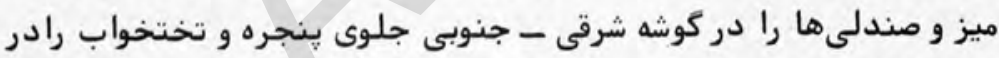

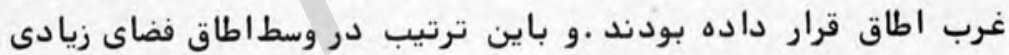

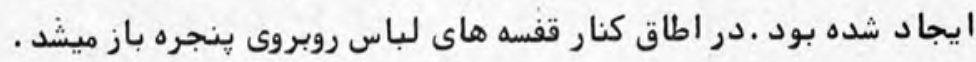

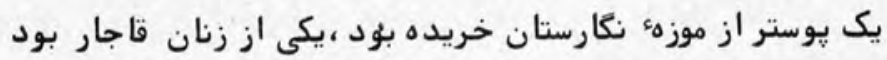

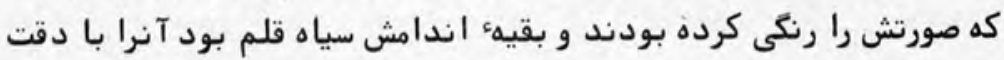

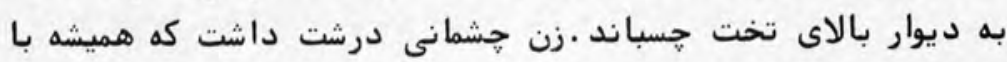

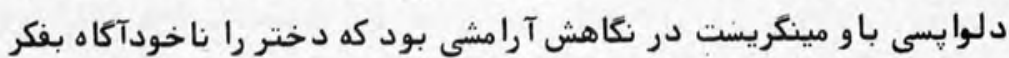

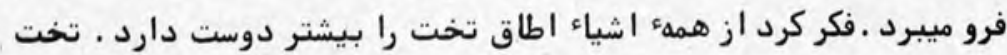

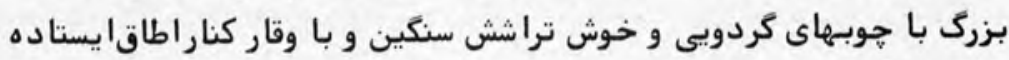

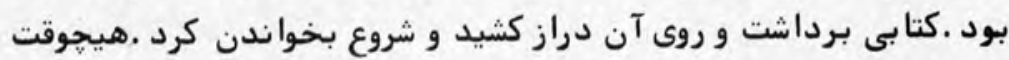
عادت نداشت روى صندلى بنشيند وكتاب بخوا ند براى همين از كتابخانه 


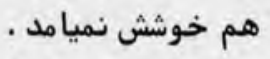

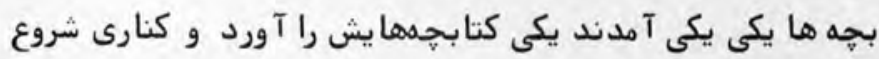

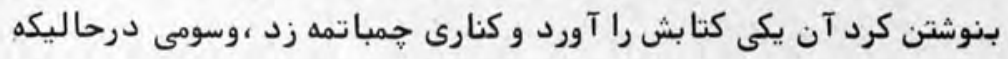

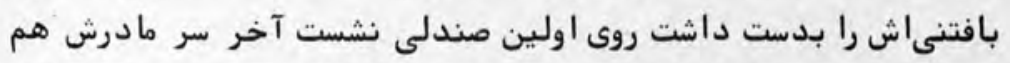

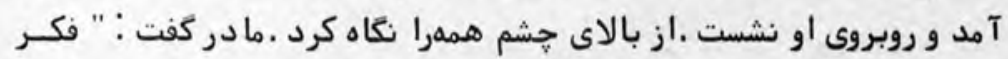

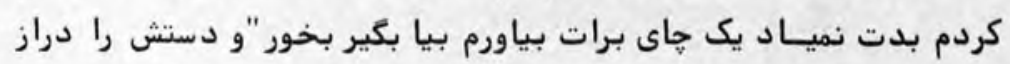

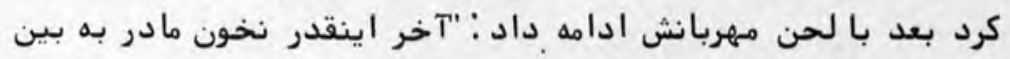

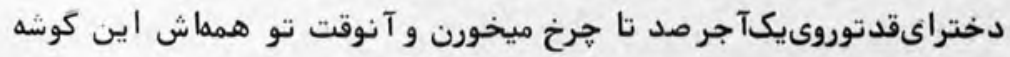
روى اين تخت مى نشينى و هى كتاب ميخونى .هيج فكر خودت ني نيستى

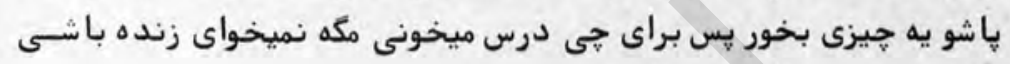

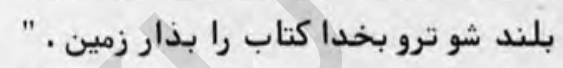

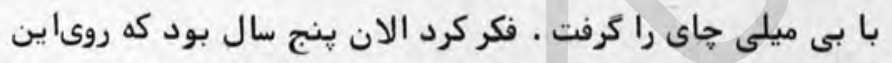

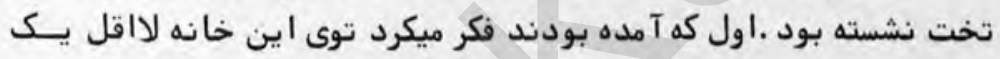

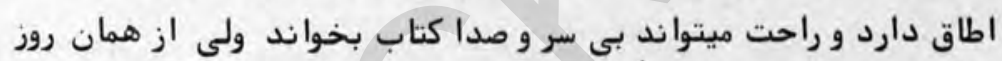

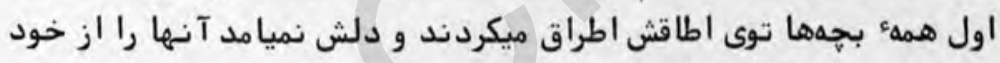

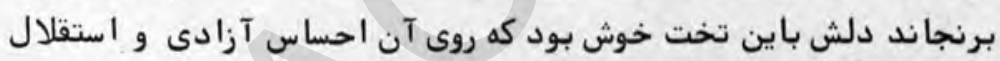

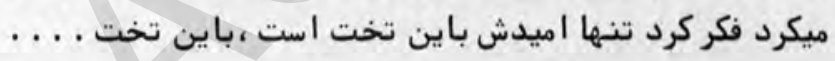

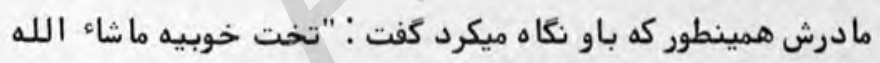

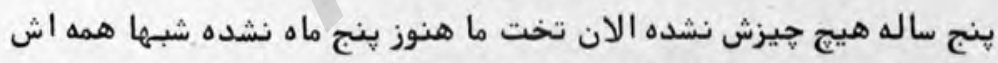

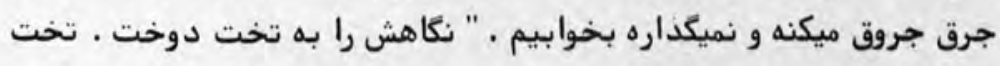

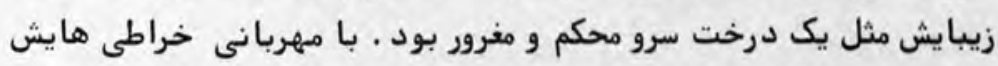

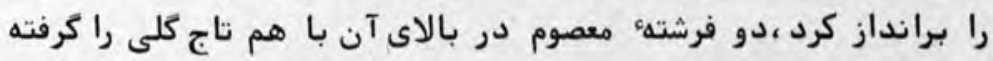

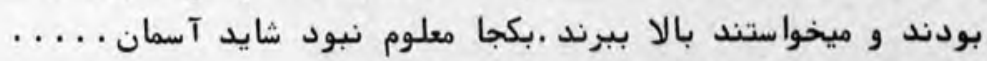

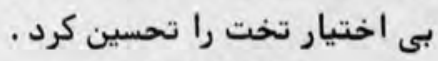

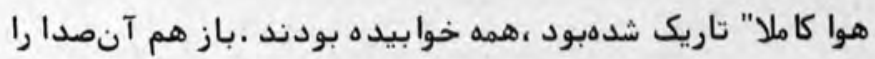

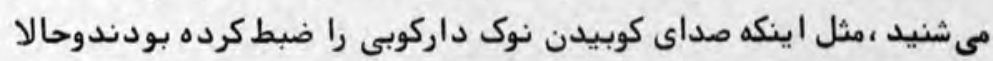

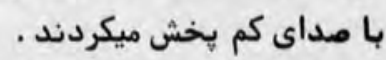
بلند شد بطرف در رفت خوب كوش كرد ، نه صدا از بيرون نبود . 
ينجره را هم باز كرد از آنطرف هم نبود .مطمئن بود صدا از اطاق است ،

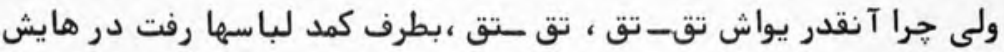

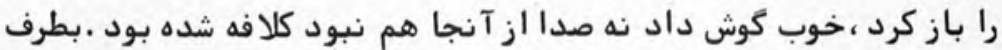

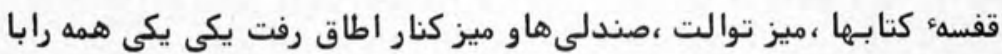

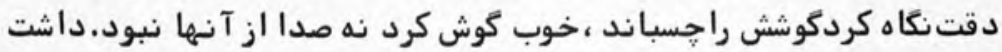
د يوا نه ميشد دور خودش مىكشت جند بار در را باز كرد بدقت كوش كـرد

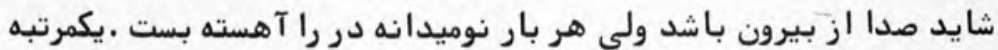

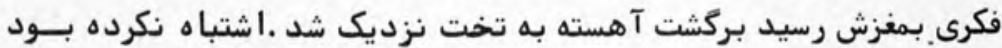

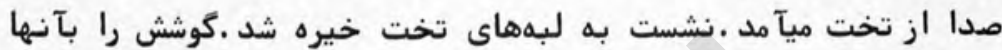

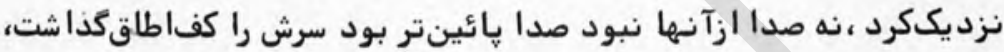
صدا نزديك تر شده بود بلند شد بزمين نزديك يا يهما نكاه كرد اطرافآ نها صها

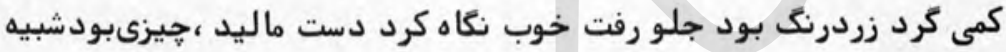

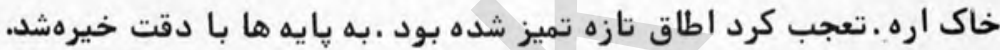

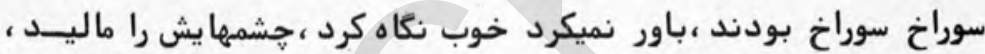

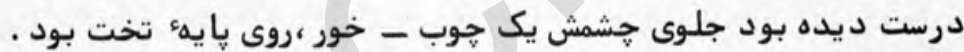

منصوره شريف زاده ه/9/9 ا 
نوشتهء : عبدالرحمن بدوى

عصرى كه انليشه جو انه مىزن

اينجا ، معبد انديشه و زادكاه خرد است ، خوشا كسانى كه دراين

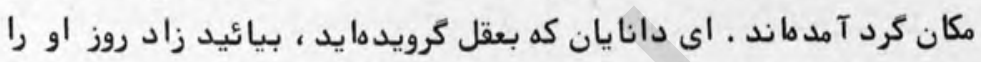

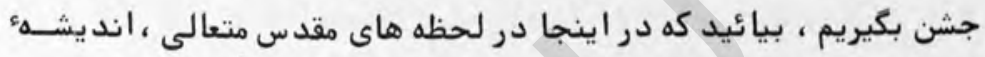

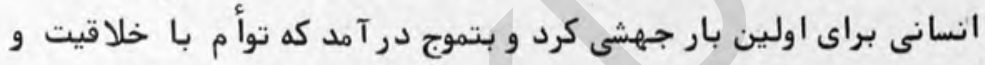

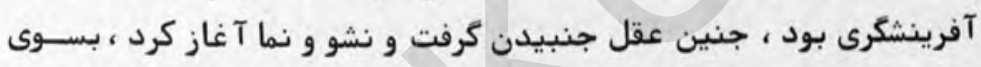

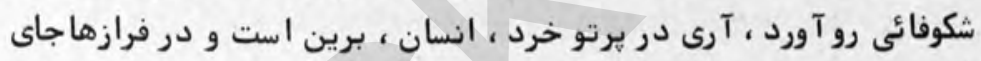

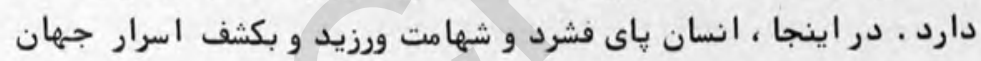

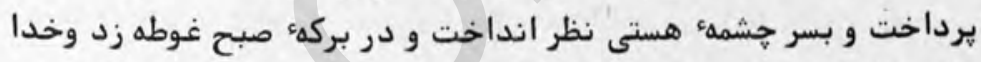

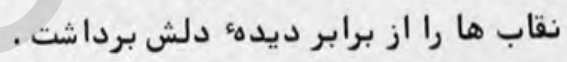

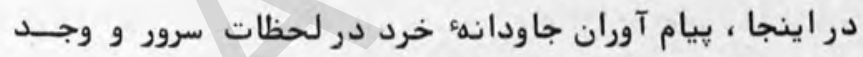

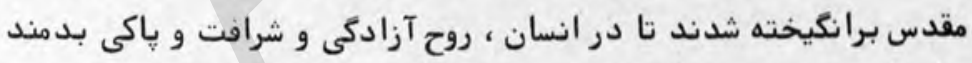

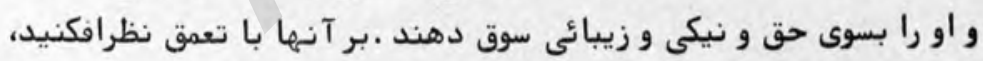

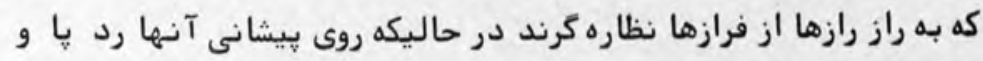

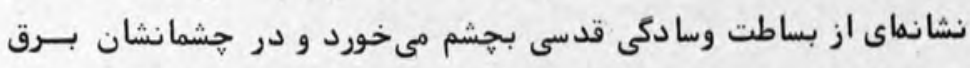

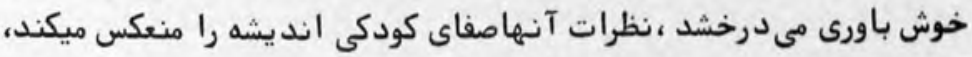

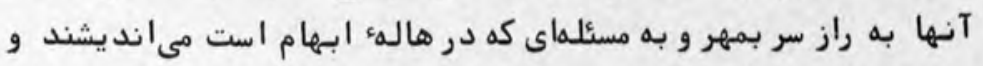
بصداى هاتف كه از ثرفاى هستى برميخيزد كوش فراميدهند ، اينك كلبانك آنه

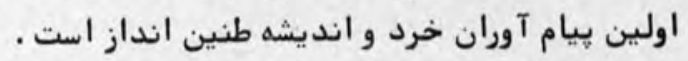

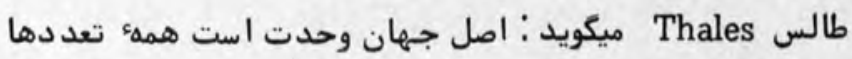

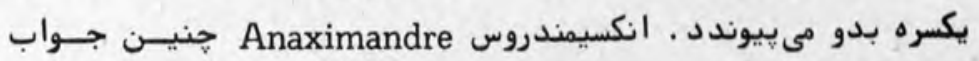

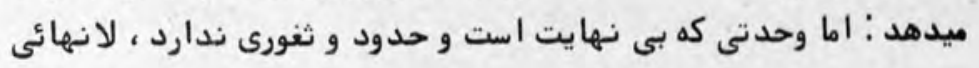


واحد است ، زندهء غنى سرشاريست ، براى اين غنى حدى نيست و ايسَن

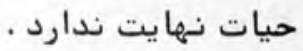

اما اين بى نهايت بودن آشفتكى هراس انكيزى مينما يد ، يسنظم

فيثاغورس Pythagore جنين سخنسرميدهد :بايد در ييشكاه

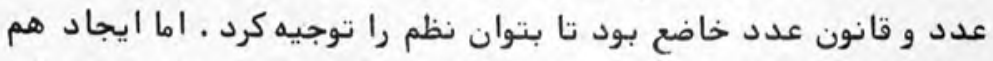

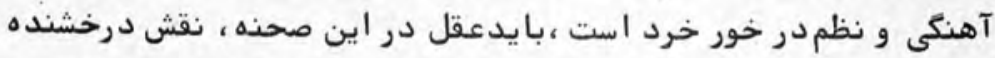

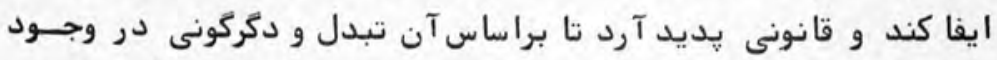

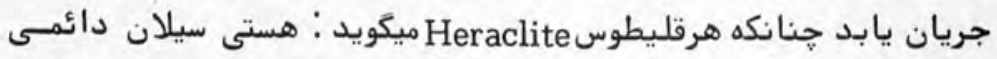

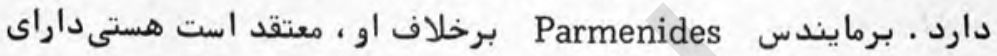

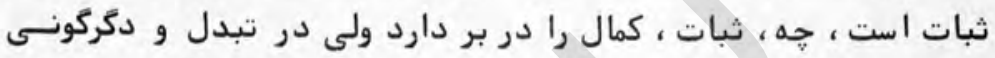

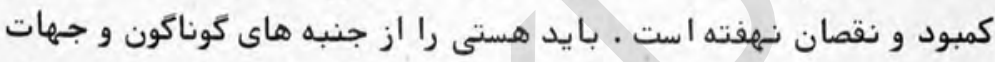

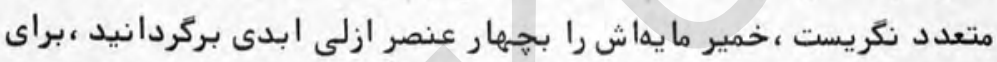

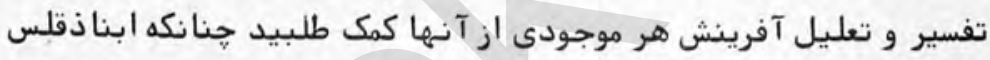

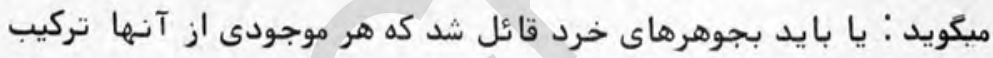

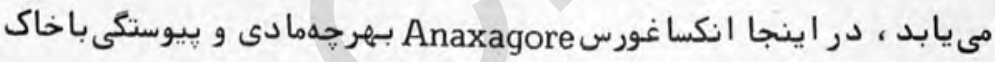

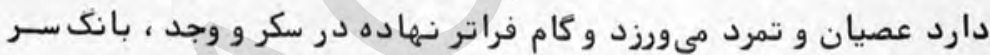

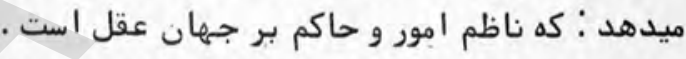

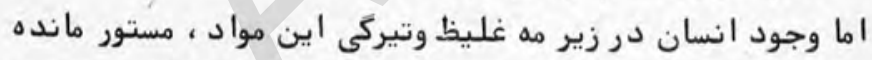

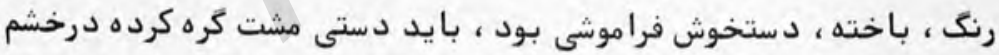

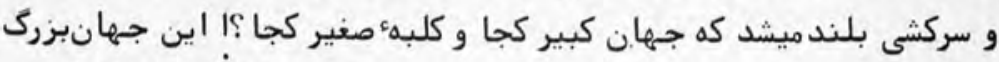

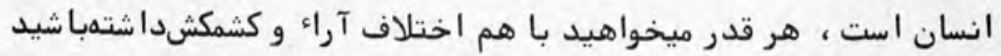

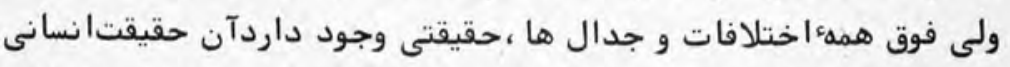

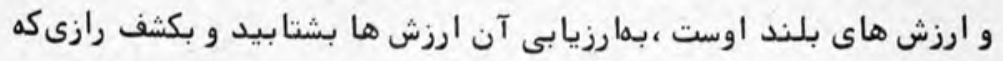

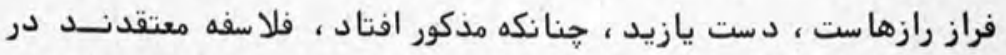

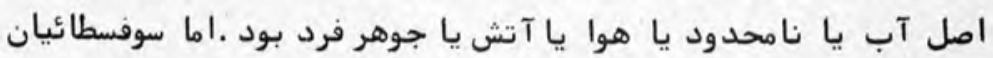

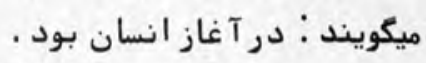

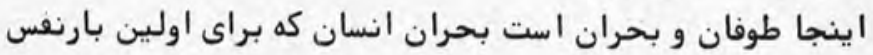


T\& 191

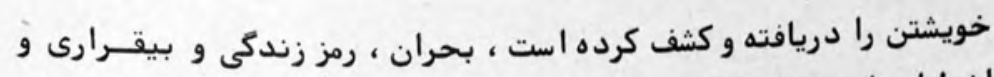

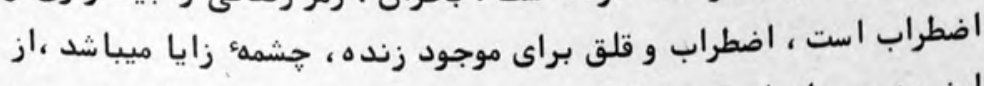

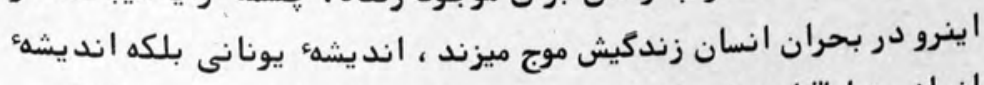

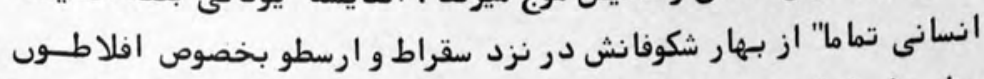

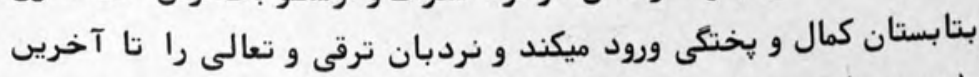

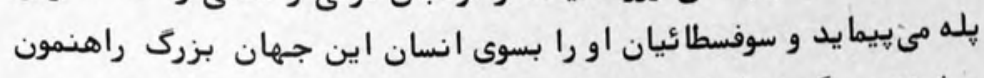

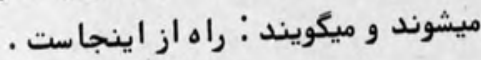

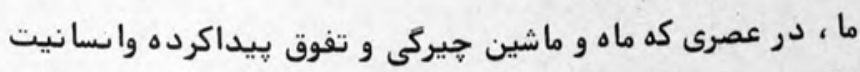

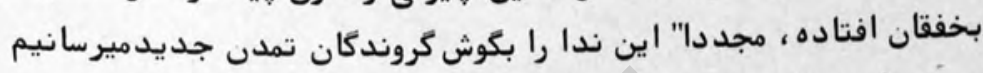

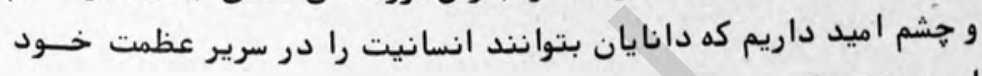
از نو تثبيت كنند اهميد كاريت

ترجمهء : رحيم نزاد سليم

ترجمهء مقالهء "داستان هاى طه حسين " كه در شمارهء قبل ازهمين مترجم به حابهرسيد نوشتهء آقاى دكتر ويكتورالكك بود كه نام نويسنده از قلم افتاده بود . 


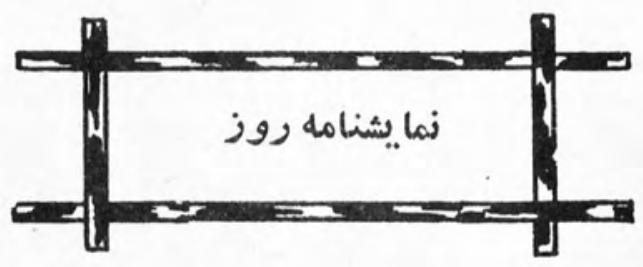

$$
\begin{aligned}
& \text { مفيستو : احضارم كردى } \\
& \text { به همكاريت شتافتم } \\
& \text { كودو: } \\
& \text { مفيستو · بله ،من كه هيج كاه }
\end{aligned}
$$

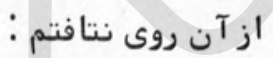

$$
\begin{aligned}
& \text { هر جا كه با تحريك علايق نفسانى نى نـ }
\end{aligned}
$$

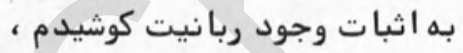

$$
\begin{aligned}
& \text { و هر كاه كه با تجسم در هيكل شيطانيم }
\end{aligned}
$$

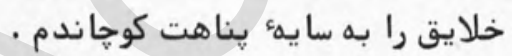

$$
\begin{aligned}
& \text { و باز ، جهه متناقضها و مبطلها كه بـ كار كشيدم }
\end{aligned}
$$

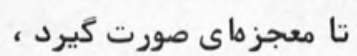

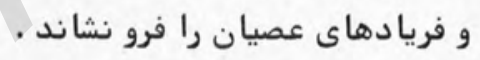

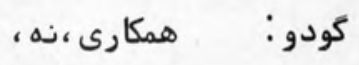

$$
\begin{aligned}
& \text { شنيدن وصف حالى ، ، شايد ، } \\
& \text { كه سخت بيمناك شدهام } \\
& \text { مفيستو: بيمناك از جه جهت } \\
& \text { آن هم با اين شدت } \\
& \text { مكر نه آسمانى كراتت }
\end{aligned}
$$




$$
\begin{aligned}
& \text { بيشاز بيش } \\
& \text { به محدودهء مدور مدار خويش بيش } \\
& \text { خو كرفته اند؟ محدودو مدور }
\end{aligned}
$$

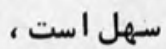

$$
\begin{aligned}
& \text { كه ستار مهاى دنباله دارت نيز }
\end{aligned}
$$

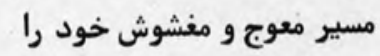

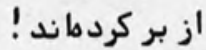

$$
\begin{aligned}
& \text { مكر نه خورشيد برد نرداند } \\
& \text { هر بامداد با شرارهماى يران }
\end{aligned}
$$

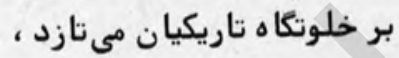

$$
\begin{aligned}
& \text {; هر غروب حون كودكى سر به فرمان }
\end{aligned}
$$

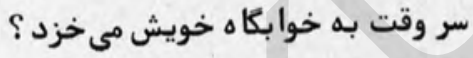

$$
\begin{aligned}
& \text { مكر 'نه حلزونى هان كيهان }
\end{aligned}
$$

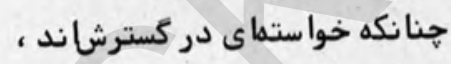

$$
\begin{aligned}
& \text { و حلزونهاى دريا كناران } \\
& \text { از رويش خود دلشاد } \\
& \text { تا روزى شكمى مقدر را شاد كنند؟ }
\end{aligned}
$$

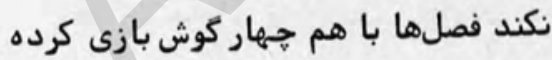

$$
\begin{aligned}
& \text { و جاى همديكر را كرفتقا ند ! }
\end{aligned}
$$

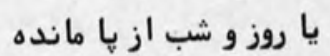

$$
\begin{aligned}
& \text { و دست از تعقيب يكديكر برداشتهاند }
\end{aligned}
$$

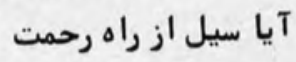

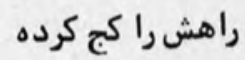

$$
\begin{aligned}
& \text { و با مدارا از كنار روستا رد شده است . عرده }
\end{aligned}
$$

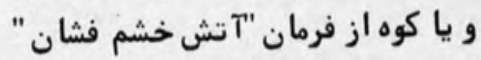

$$
\begin{aligned}
& \text { سر ييهى كرده } \\
& \text { واز سر مردمى تئى كرده } \\
& \text { بر سر مردمان آتش فرو نباريده است؟ }
\end{aligned}
$$




$$
\text { حركت زمان }
$$$$
\text { و داس مركى }
$$

كه كند نشده است مرد ،

$$
\text { يس بيمناك هرا؟ }
$$

كودو : از آدمى انديشناكم از قيام قبل از قيامتش، از موريانه موذى موشكافيش •

مفيستو : انديشناك ازآدميان ؟

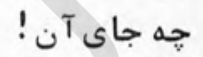
آرامكاه مقربانت كه آرامبخش آلامشان است ، معردان هيبت نامت كه موجهاى كرنش را

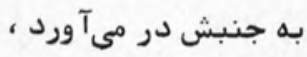
كتاب بهايت جنس كه درس اولين و آخرين ، و خاك آستا نت

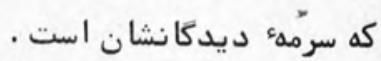
قانون شكنى هاى مصلحتى را

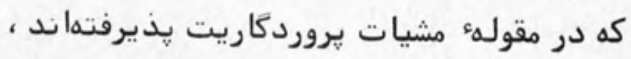
و دل و دو دو موله

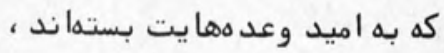
ديكر انديشناك جرا؟

$$
\begin{aligned}
& \text { كودو : از كذشته يشيمانم }
\end{aligned}
$$

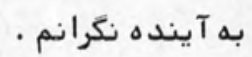




$$
\begin{aligned}
& \text { در آفرينش آدم }
\end{aligned}
$$

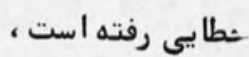

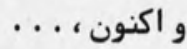

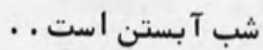

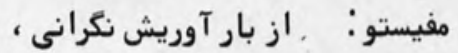

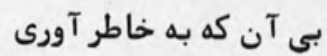

$$
\begin{aligned}
& \text { كه بند بند بدنش }
\end{aligned}
$$

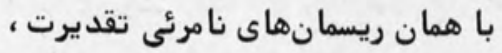

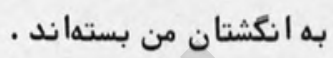

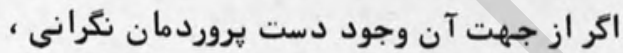

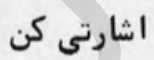

$$
\begin{aligned}
& \text { تا او را به رقصى كه بايد در آورم . } \\
& \text { كودو : همهء رنكها را بر يّيكرش آراستم ، }
\end{aligned}
$$

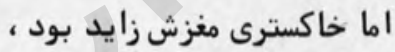

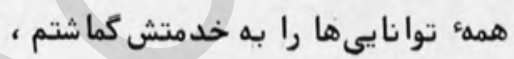

$$
\begin{aligned}
& \text { ولى اعطاى اند يشكرى جايز نبود . } \\
& \text { مفيستو: آدمى دمدمى است، }
\end{aligned}
$$

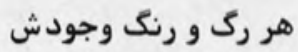

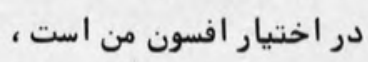

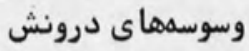

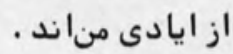

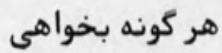

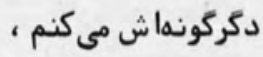

$$
\begin{aligned}
& \text { به هر راه روا دانى } \\
& \text { روانها ش مى دارم . }
\end{aligned}
$$




$$
\begin{aligned}
& \text { كودو . اشتباه تو } \\
& \text { و انديشناكى من } \\
& \text { در همين جاست . } \\
& \text { او راها ند يشكريش را هموار }
\end{aligned}
$$

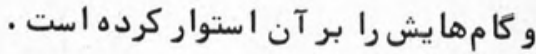

$$
\begin{aligned}
& \text { در هر مقام ديكر } \\
& \text { بى تدبير }
\end{aligned}
$$

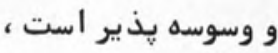

$$
\begin{aligned}
& \text { جز در اين يك. }
\end{aligned}
$$$$
\text { همهء رنكها يش در نكين نفوذ توست . }
$$$$
\text { جز رنك خاكستريش }
$$$$
\text { كه خنثى است ، }
$$$$
\text { و من از بارورى همان انديشناكم المن ، }
$$

$$
\begin{aligned}
& \text { مفيستو: بِلها را خواهم يراند، }
\end{aligned}
$$

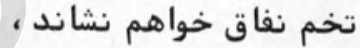$$
\text { تيركىها را به تهاجم در خواهم آورد ، }
$$$$
\text { بر رواج حَب هاى اعتياد به حُب جاه بهاه }
$$

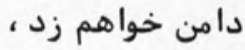$$
\text { تا روزنههاى بينايى بر او بسته شود ، }
$$$$
\text { تا از يويش خود خسته شود . }
$$

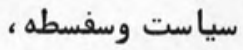$$
\text { تبليغ و تحذير ، وسفوس ، }
$$

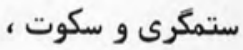$$
\text { تعصب و تكفير ، }
$$$$
\text { و عشرت و آزمندى را }
$$

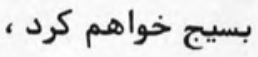$$
\text { تا در همش كوبند }
$$ 
سخن دورهءء

$$
\text { و جنين تهديدكر را }
$$

در زهدان انديشهاش بكشند .

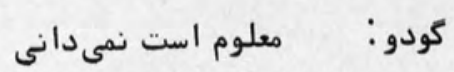

$$
\begin{aligned}
& \text { كه در اين نيرنكها } \\
& \text { ديكر رنكى نيست . نيكن } \\
& \text { و حريف } \\
& \text { در راهى كه جسته } \\
& \text { هشم بر هر داعيهء ديكر بسته } \\
& \text { و از دام هر فريب رسته است . } \\
& \text { مكر غافلى } \\
& \text { كه حندى است انديشها ش را } \\
& \text { نفخهء نكرش } \\
& \text { آ بستن كرده است ، } \\
& \text { و نوزاد آن اينك در راه . .. بردهن }
\end{aligned}
$$




\section{اقتباس از يك افسانهُ هحلى}

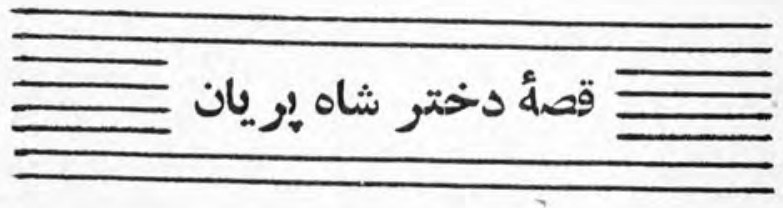

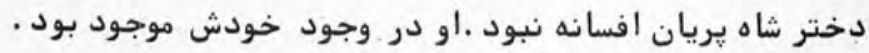

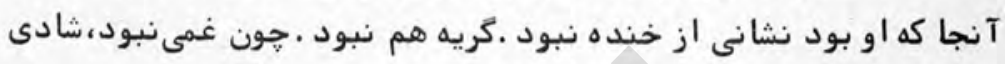

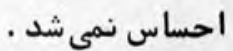

روزى از روزها دختر شاه بريان از قله كوه بلندى كه بر آن آشيان

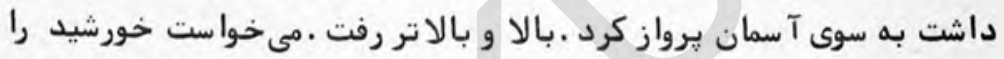

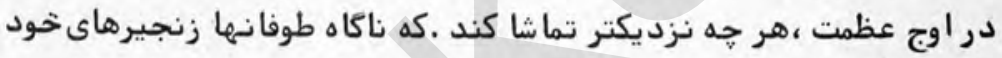

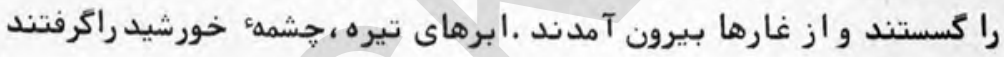

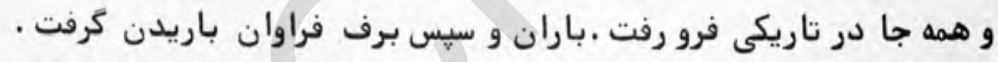

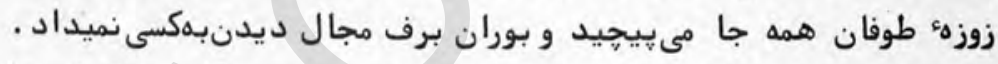

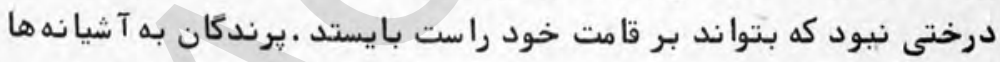

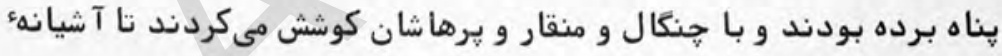

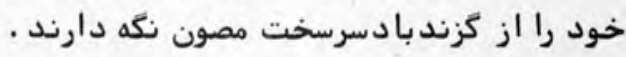

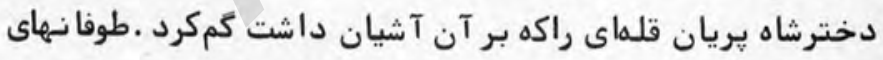

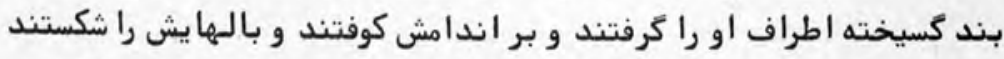

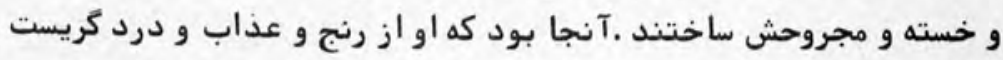
و اشك متولد شد.

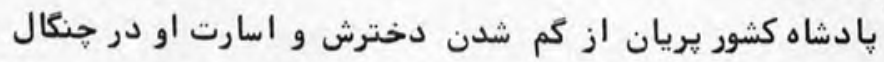

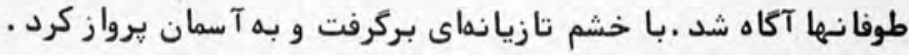

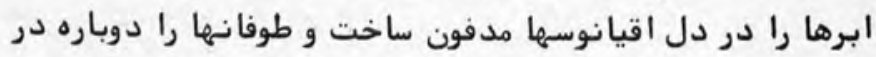

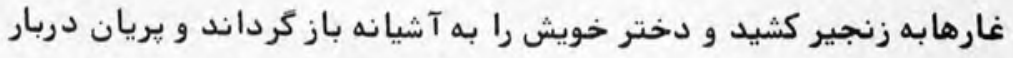

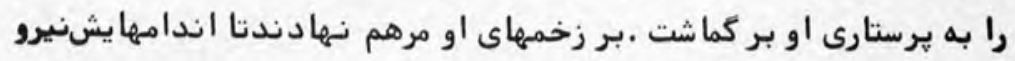
كرفت و يرهاى شكستماش دوباره روئيد . 
زمان سريعتر از كدشته كدشت و دورانى خوش و با شكوهييدا آمد.

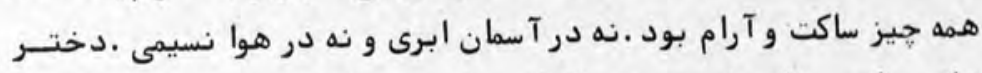

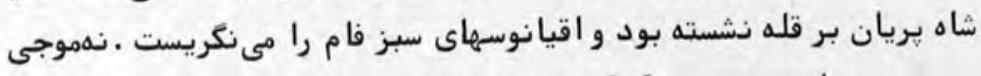

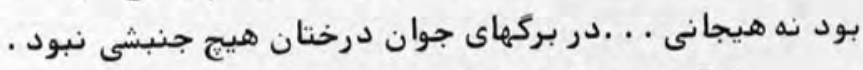

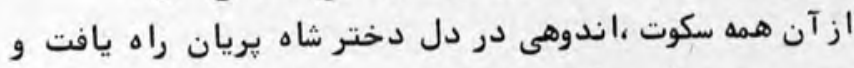

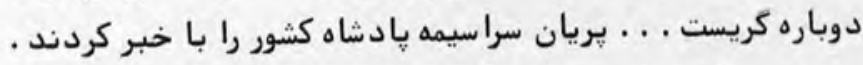

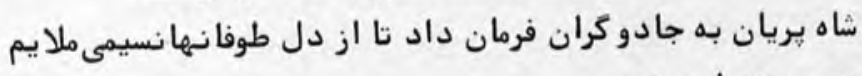

$$
\text { بيرون كشند و بنزد او برند . بـان. }
$$

صبح بود كه نسيمى ملايم وزيدن كرفت و برن بادن بالـهاى دختر شاه

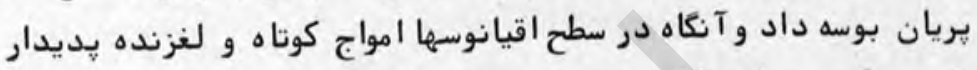

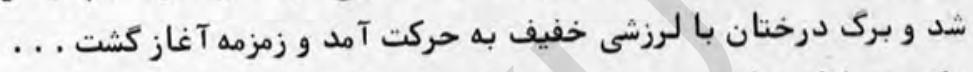

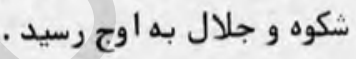
دختر شاه يريان بار ديكر به تما شاىخورشيد از قله به سوى بآ سمان

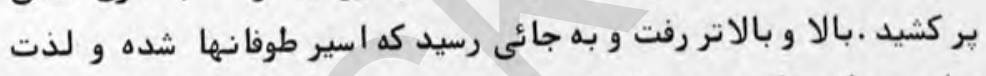

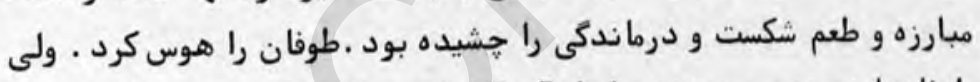

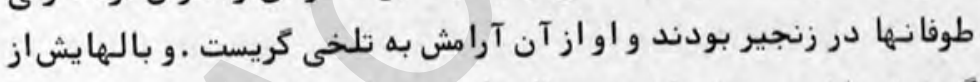

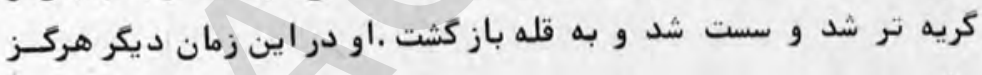

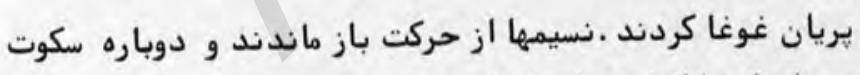

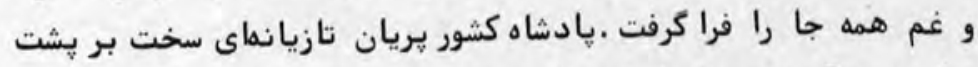

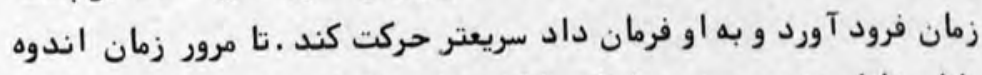

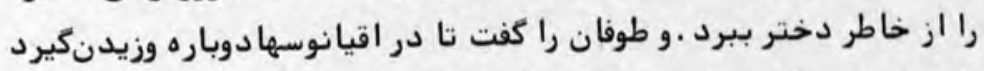

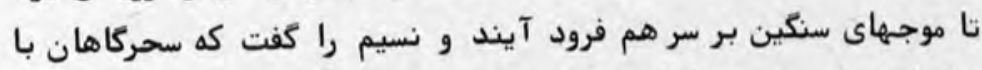

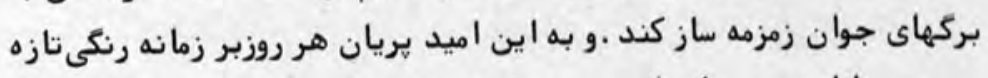

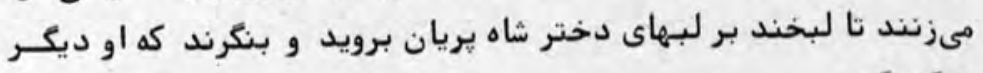

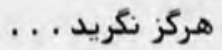

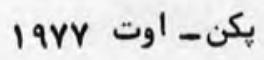

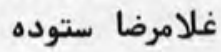




\section{ادبيات فارسى در وومانى}

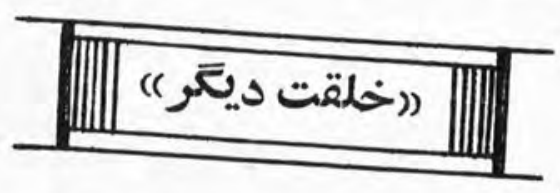

به جمال مير صادتى

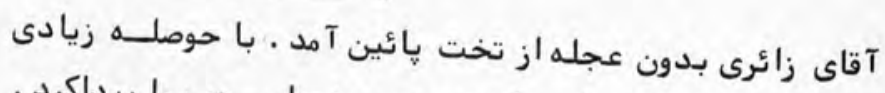

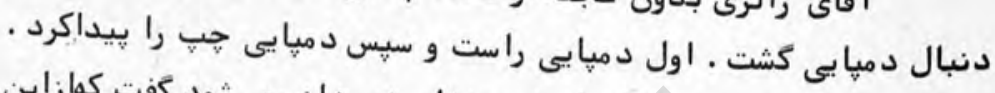

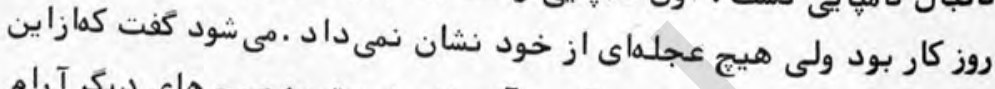

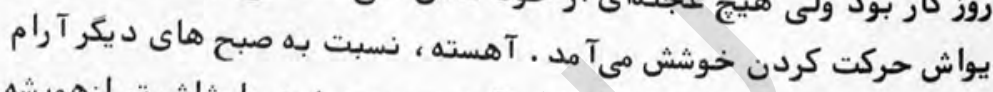

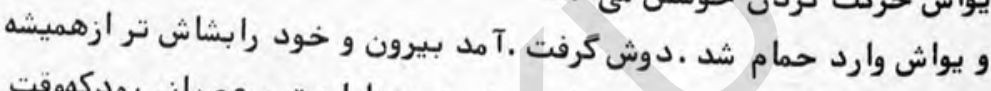

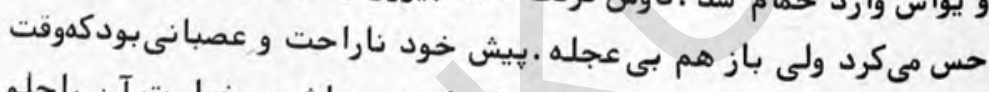

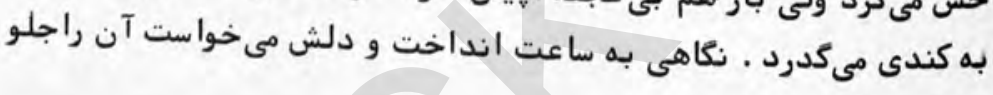

آقاى زائرى با توجه زيادى جلوى آئينه لباس يوشيد وآما دهرفتن

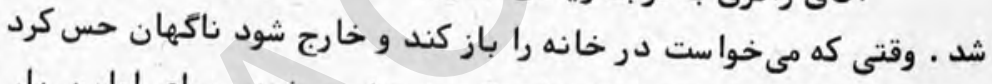

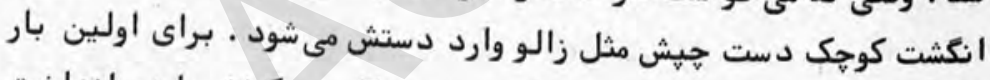

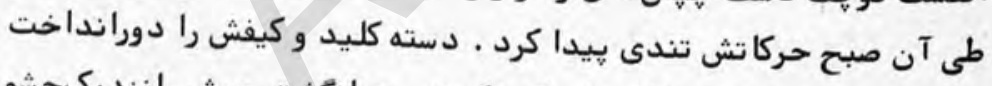

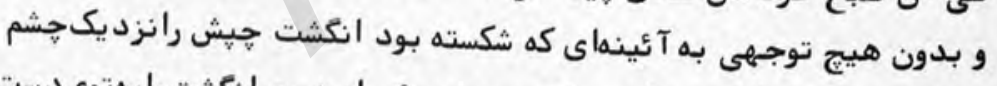

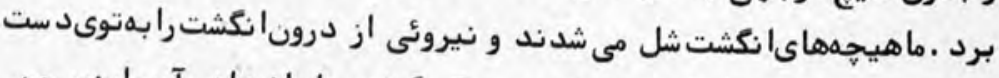

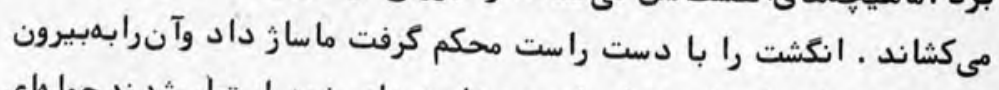

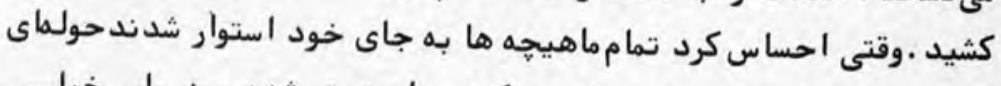

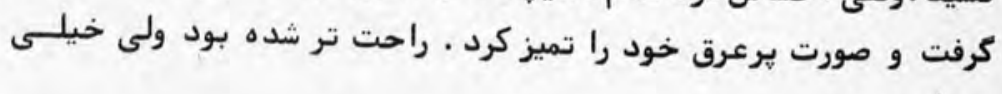

" آقاى زائرى از اطاق خارج شد و با احتياط از لِله ها لائين رفت . تنها.

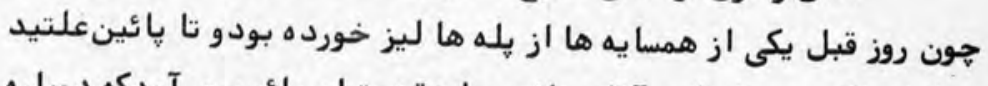

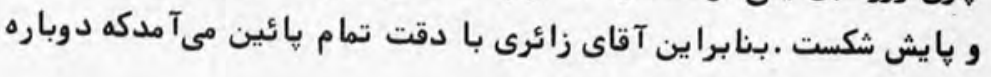


دورهء frA

حس كرد همان انكشت سعى مىكند وارد دستش بشود . اين دفعهآن راميان

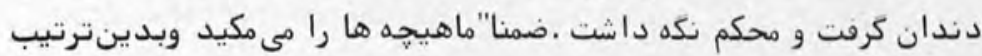

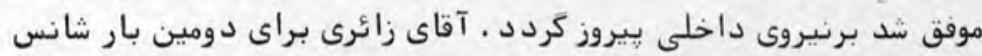

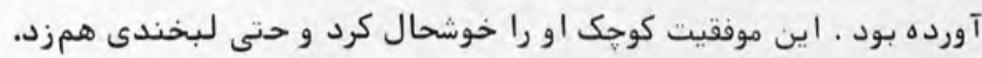

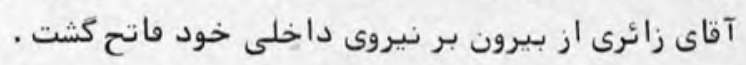

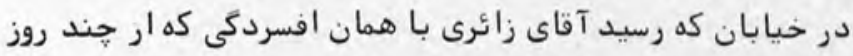

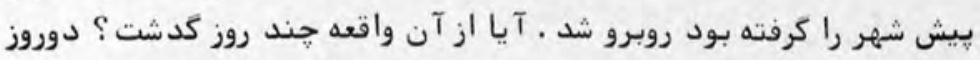

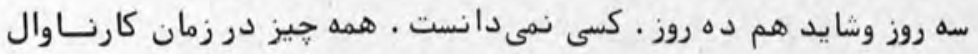

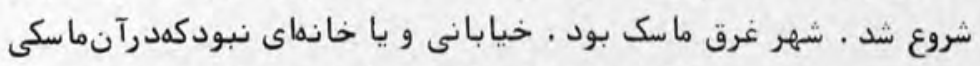

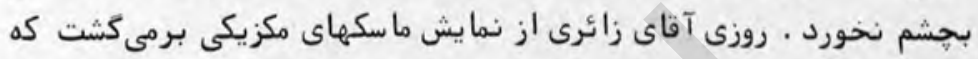

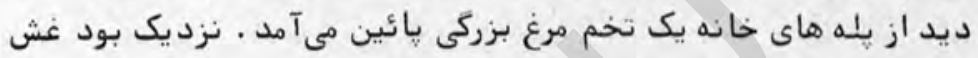

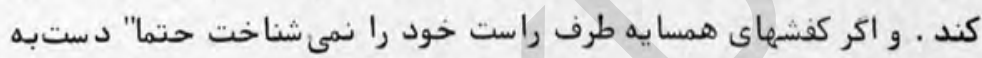

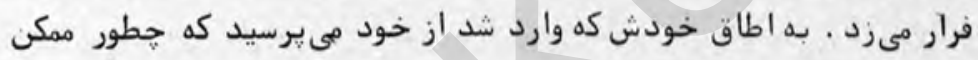

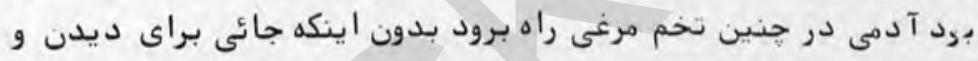

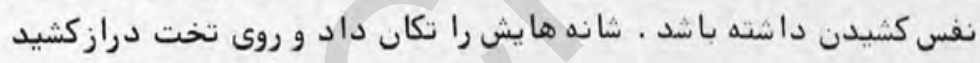

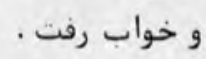
آقاى زائرى روز بعد در مسير خود بطرف اداره دو يا سه تخم مرغ

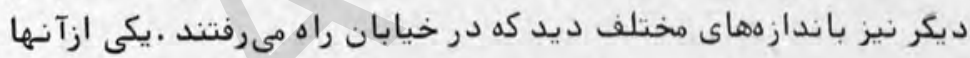

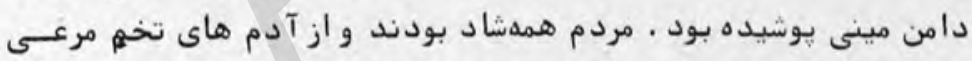

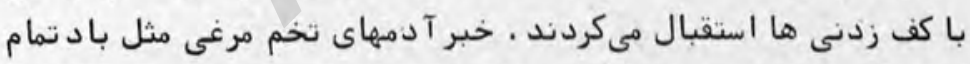

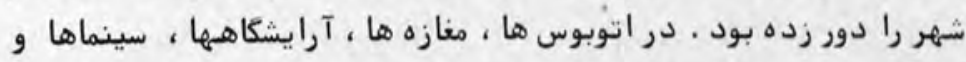

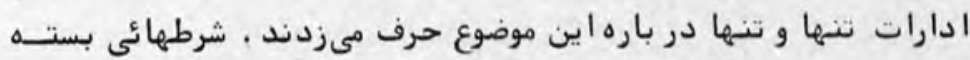

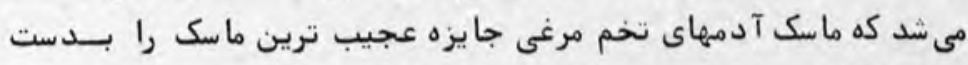

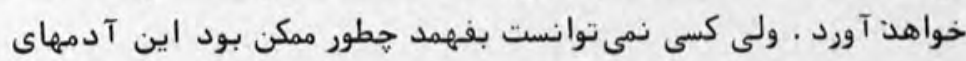

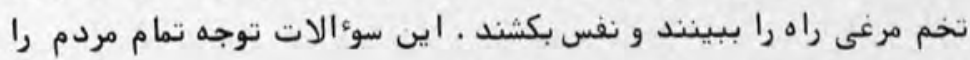

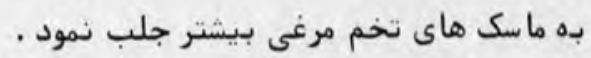

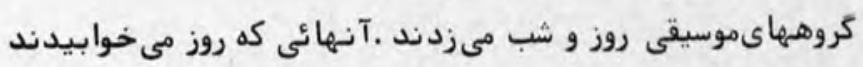

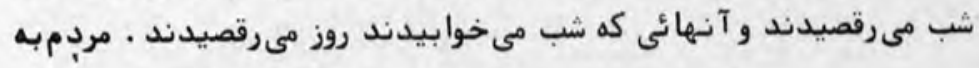


ادارات سرى مىزدند فقط براى خوردن خائى و شنيدن خبرهاى تـازه در در

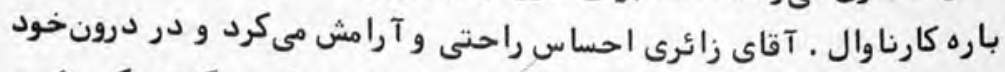

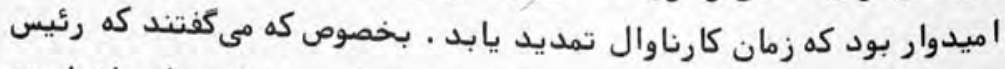

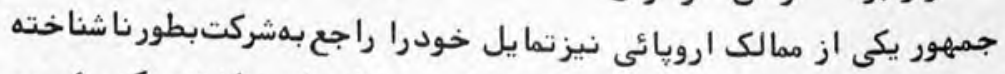

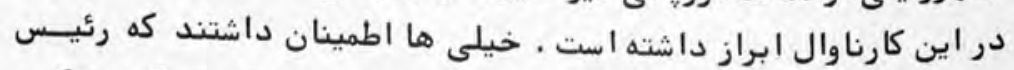

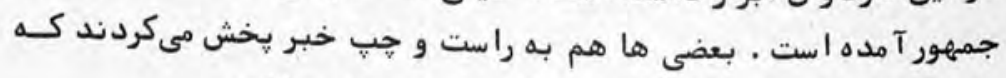

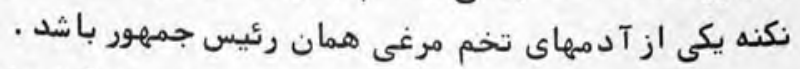

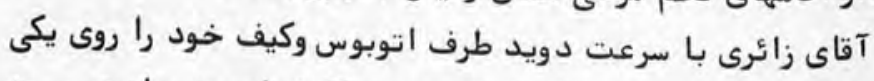

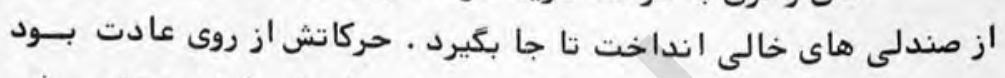

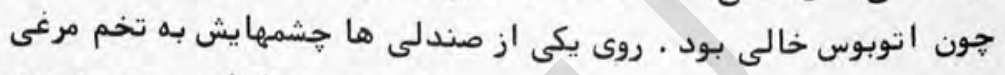

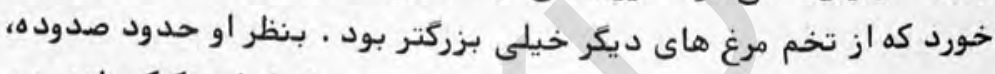

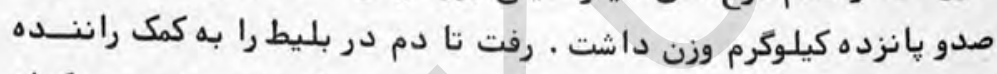

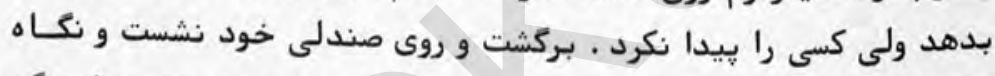

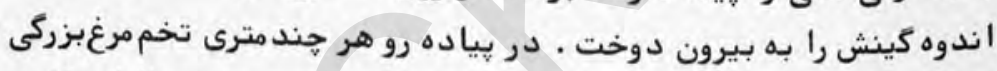

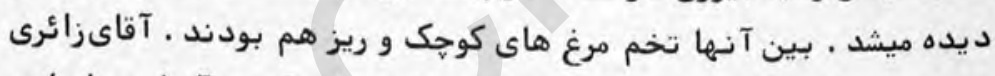

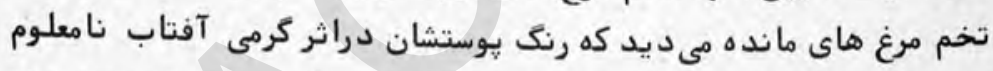

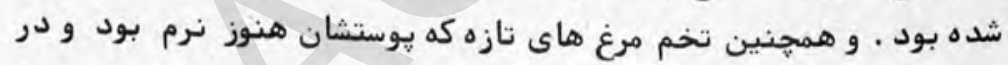
آنهيا حركتى مى مديد.

اتوبوس آقاى زائرى از برا بر ميدانى كذشت كه راز تخم مرغ هادر

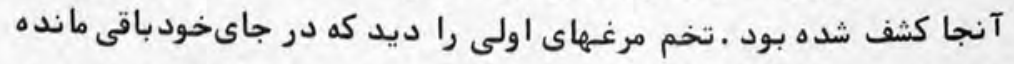

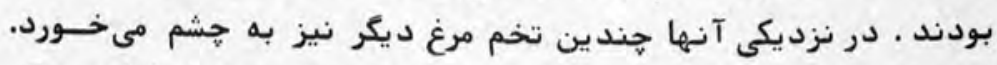

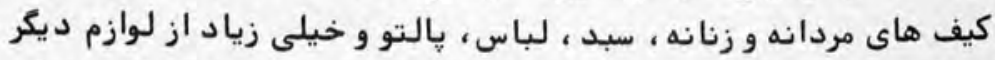

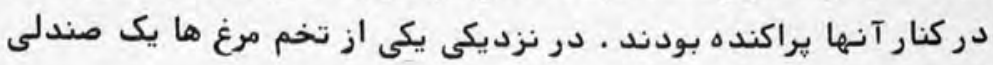

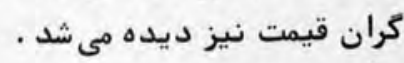

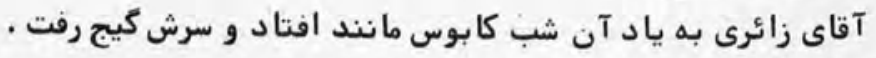

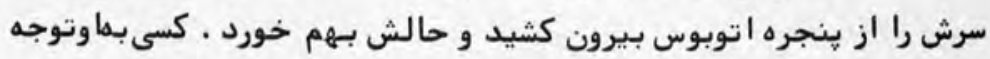
نكرد. در شبى كه آقاى زائرى به يادآن افتاده بوديكى ازما سكهامهمانى 
بزركى راه انداخته بود و هر كسى كه ميل داشت مى توانست در آن شركت

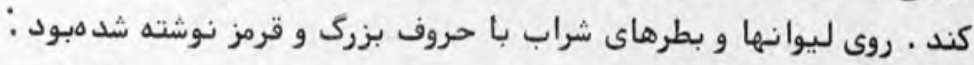

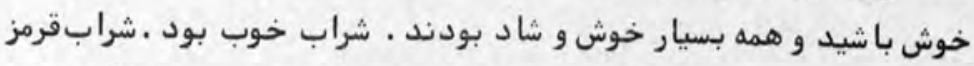

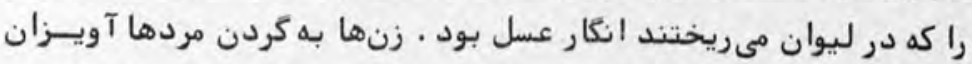

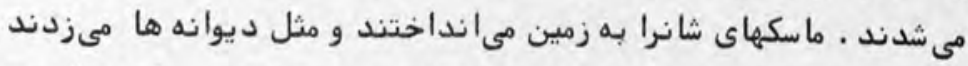

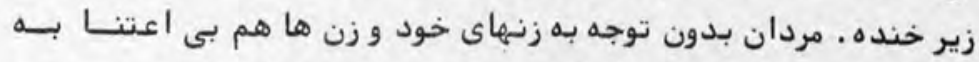

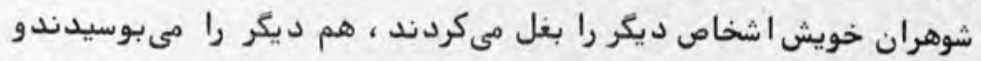

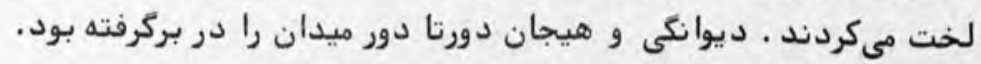

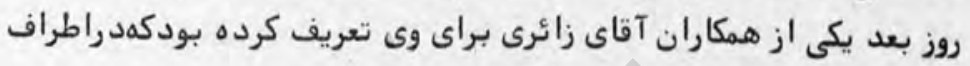

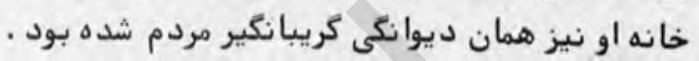

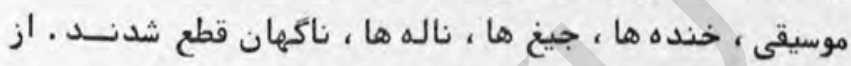

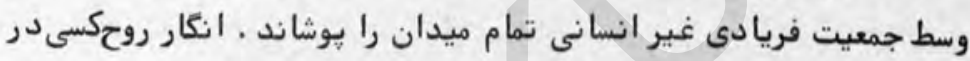

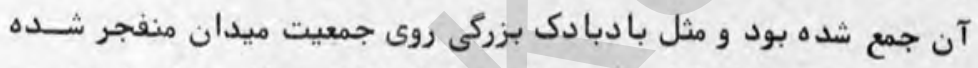

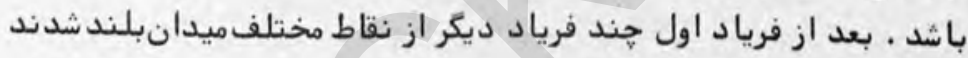

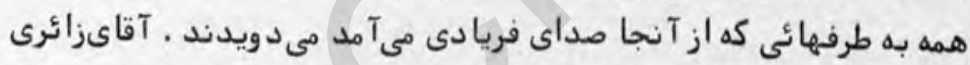

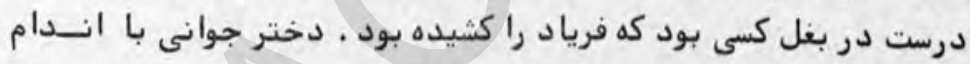

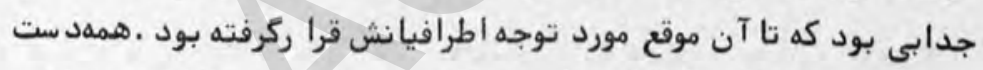

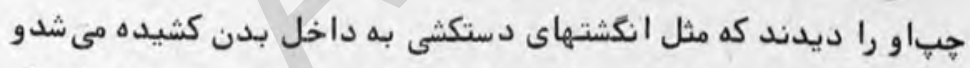

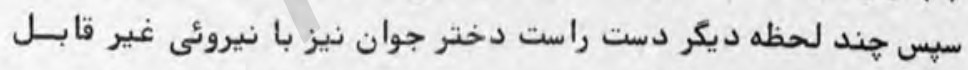

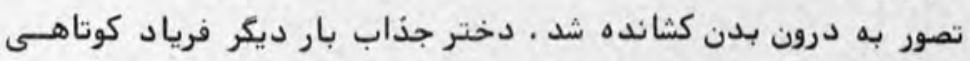

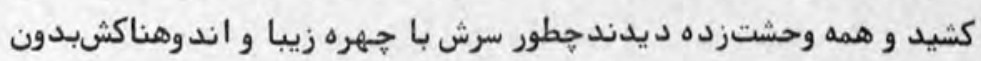

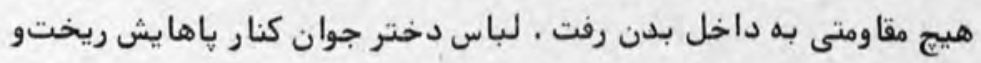

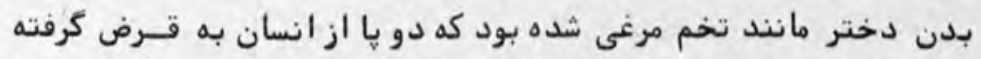

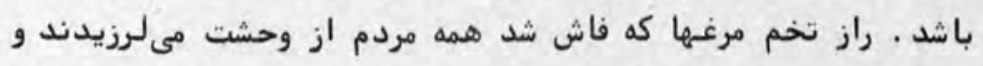

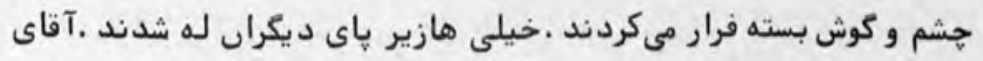

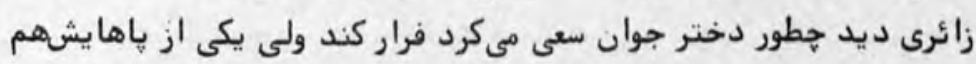

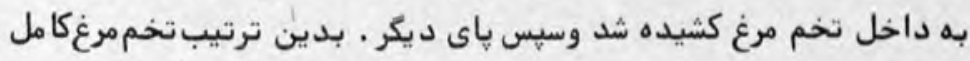

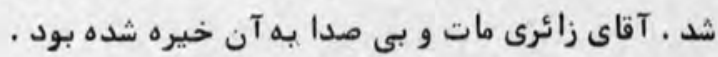


PNI

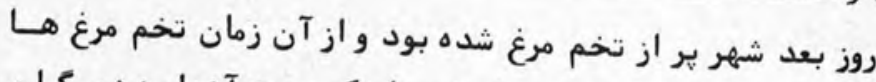

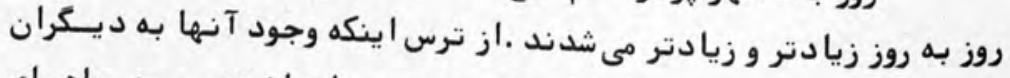

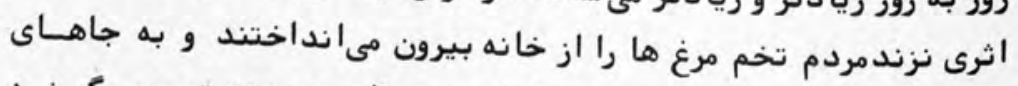

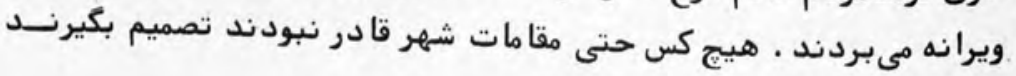

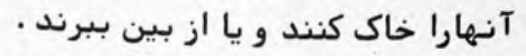

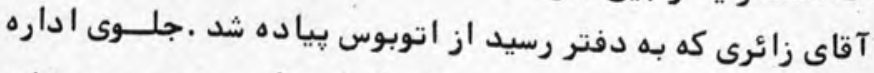

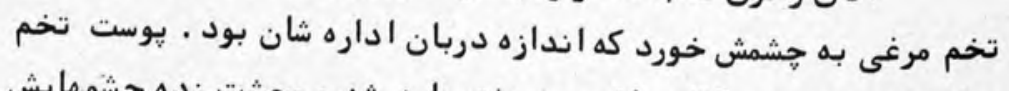

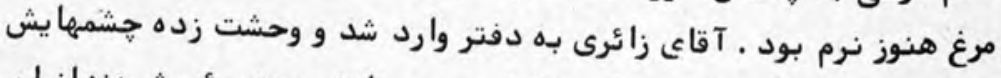

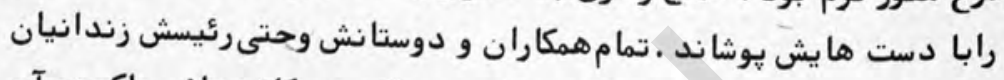

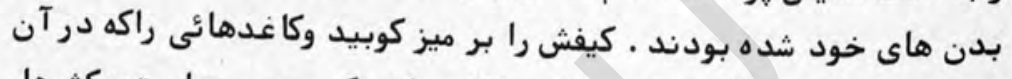

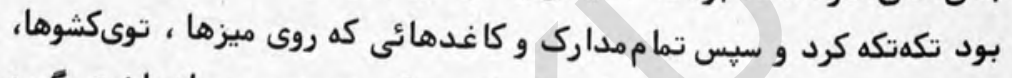

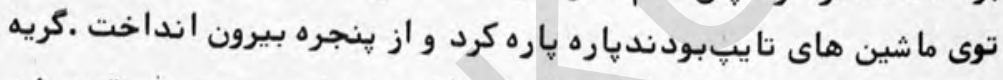

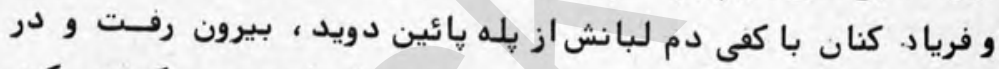

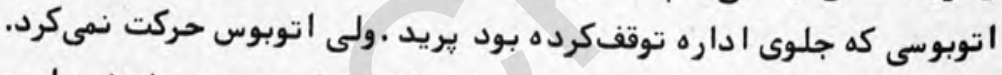

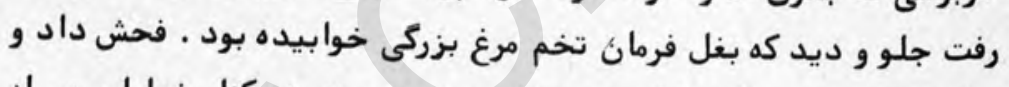

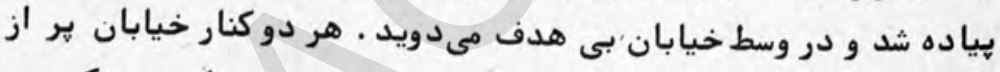

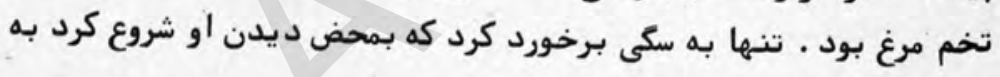

وا سيله سوفى نتى

تهران 19 


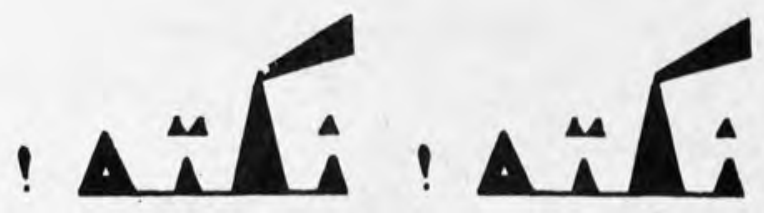

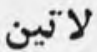

روزى در اطاق يكى از سران و سروران يكى از دستكاههاني ادارى كان

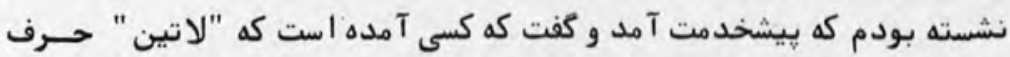

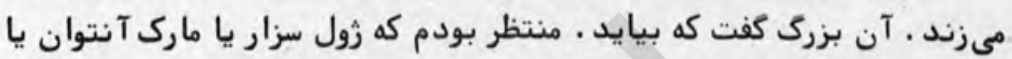

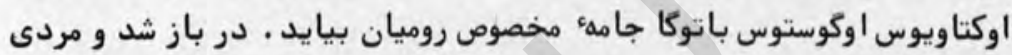

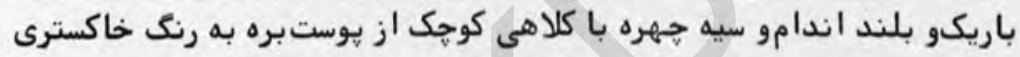

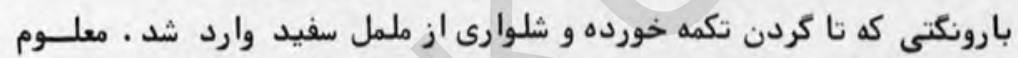

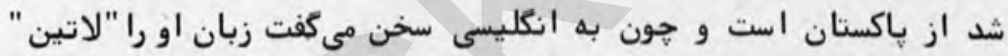
تشخيص داده بودند.

جندى است كه در ميان كارمندان ادارى و نيز ديكر مادر مردم درس

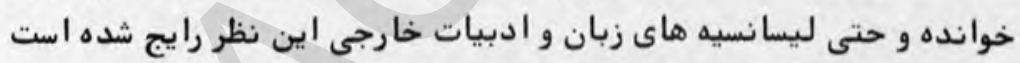

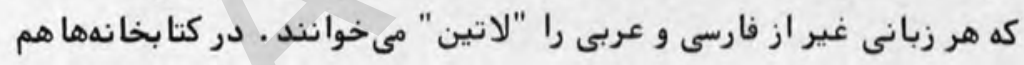

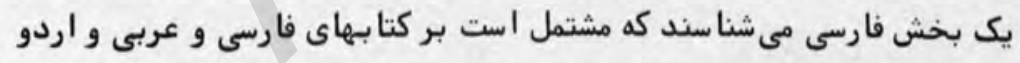

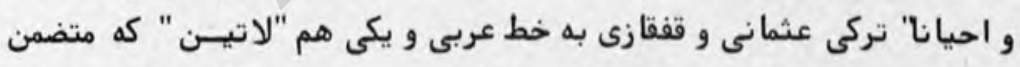

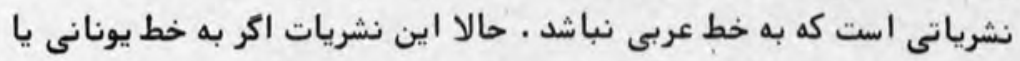

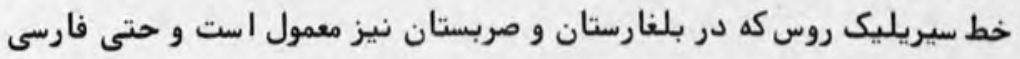

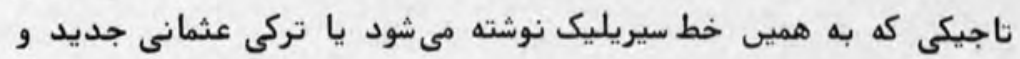

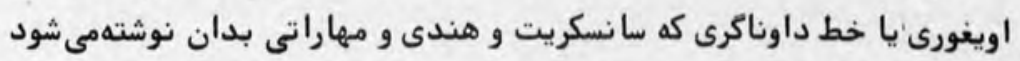

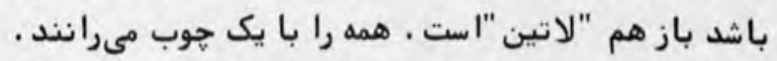

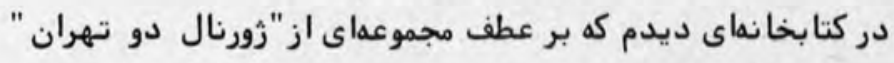

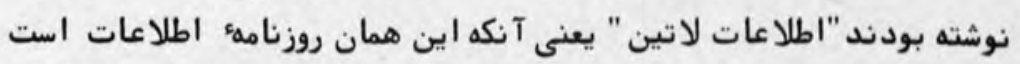

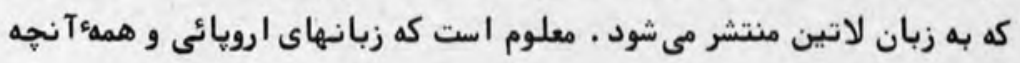


fAr

نكته نكته

$$
\text { به خط لاتين و غيره نوشته مى شود "لاتين " است . }
$$

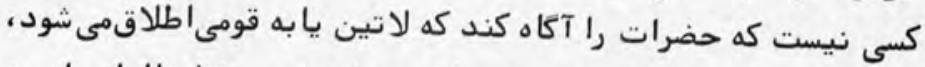
هند و ارويائى كه در هزارهء دوم يِيش از ميلاد به شبه جزيرهء ا يتالياى امروز راه جستند و در استان لاتينوم ساكن كشتند و يا به زبان لاتينى مى هويند كه كه

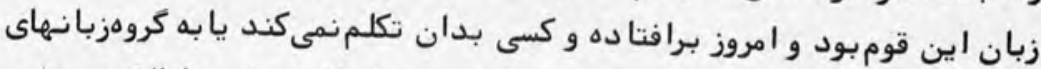

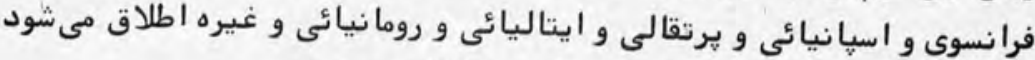

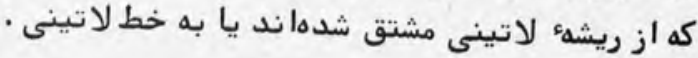

\section{ستاد عملياتى توزيع آجر}

در يكى از روزنامه هاى ير تيراز و معروف اين عنوان به حشمم خورد " ستاد عملياتى توزيع آجر تشكيل شد" .نمرديم و مانديمو براى آجر هم سياه

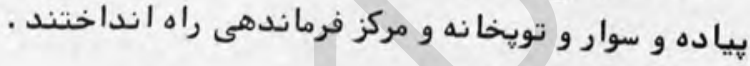

\section{دست خود را از دست داد}

از عبارات مضحك يكى "از دست دادن" است . به جاى اينكهبكويند فلانكس مرد يا دركذشت يا فوت كرد مىكويند جان خود را از دست داد . . با با بان اينكه لفظ"خود "در اينجا زيادى همهست .زيرا كسى جان ديكرى رانمىتواند از دست خودش بدهد . به جاى آنكه بكويند دستش قطع شد مىكويند دست

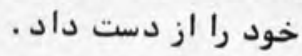

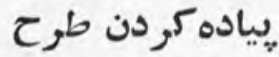

معلوم نشد كه اصطلاح "يياده كردن " كه براى اجرا و عملى ساختن معمول شده است از كجا ناشى شده است . ولى ازَّن آصطلاحاتى است كهبايد

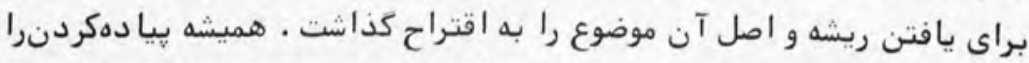
براى جدا كردن اجزاء بكار مى بردند .مثلا" زركر دستبند را يياده كرد .

ز.j

عبارت "جوانان زبر بيست و بالاى هيجده سال" يا نظايــر آن در 



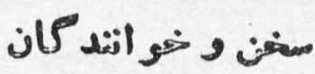

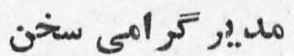

دوست شاعرم آثاى" واصف باخترى" در يك نامهء شخصى كه از

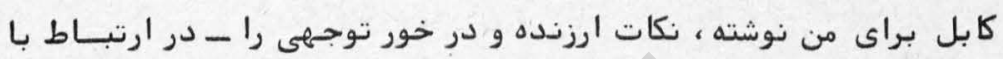

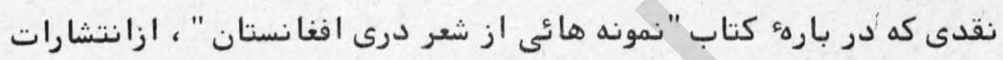

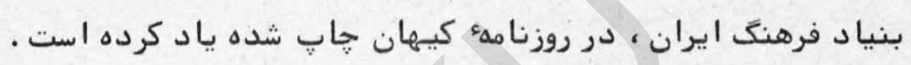

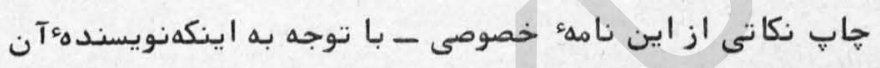
يكى از جهره هاى درخشان شعر امروز و از نويسندكان صاحبنظر افغانستان

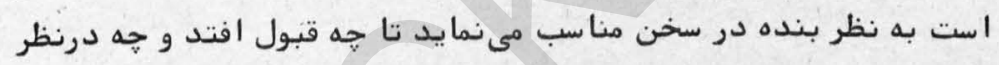
آيد. شاكرد ارادتمندتان - ناصر اميرى

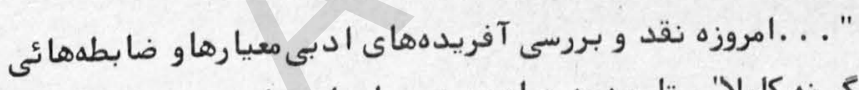

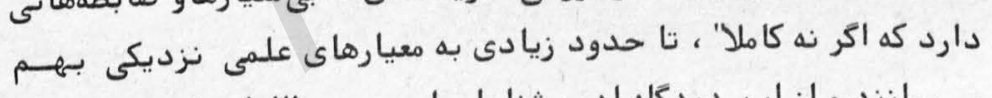

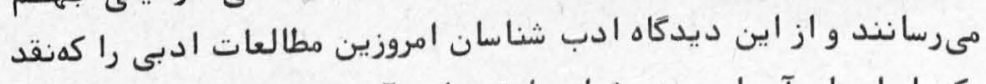

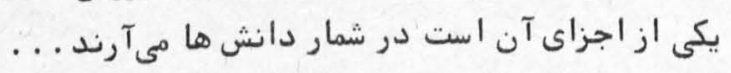

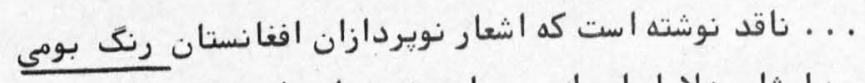

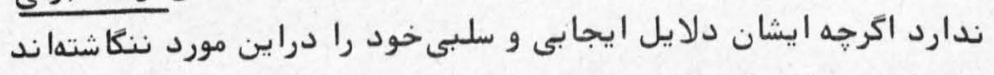

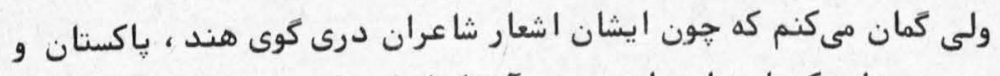

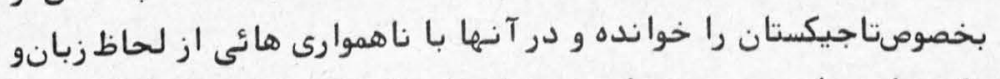

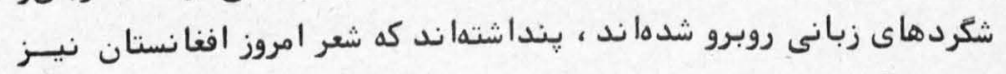

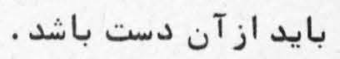




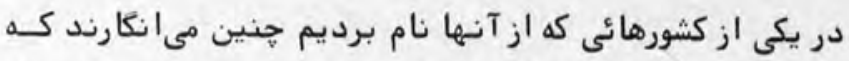

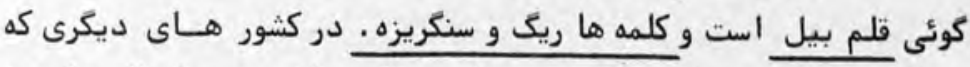

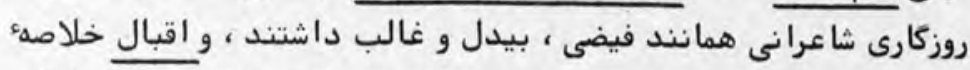

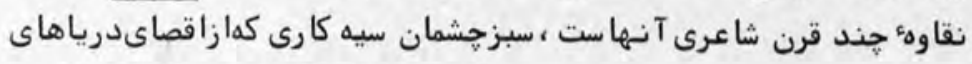

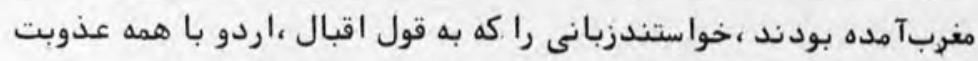

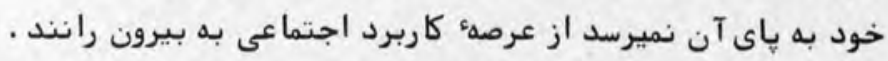

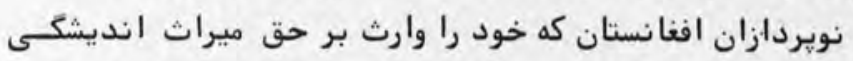

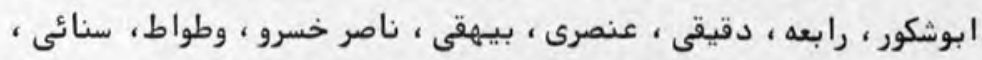

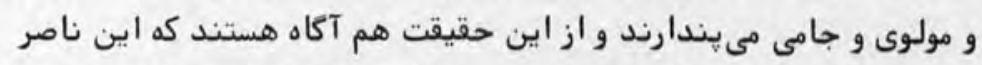

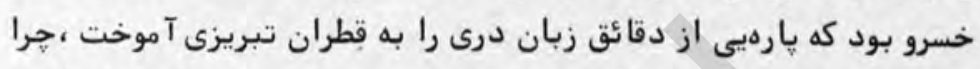

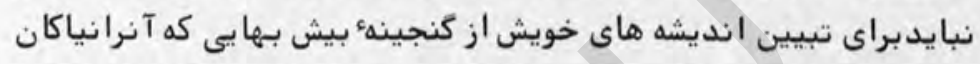

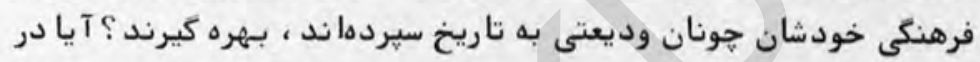

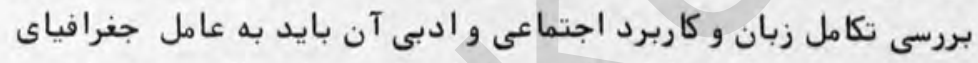

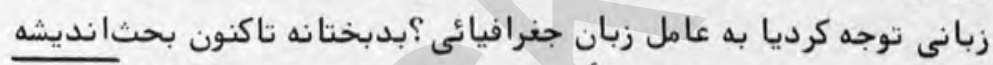

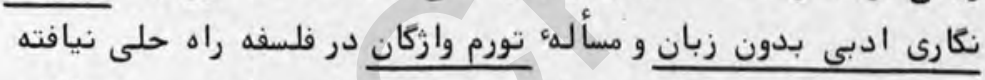

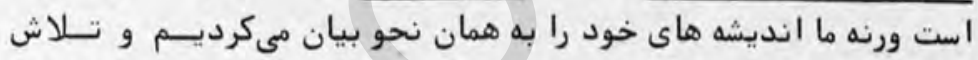

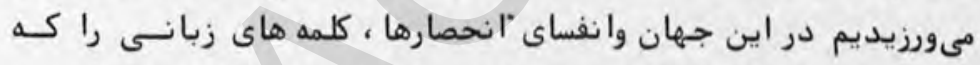

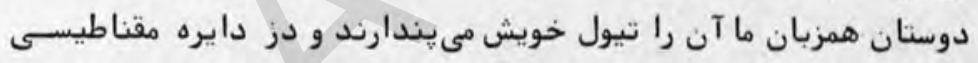

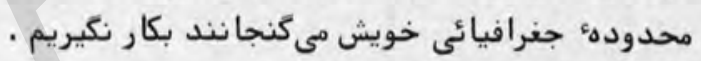

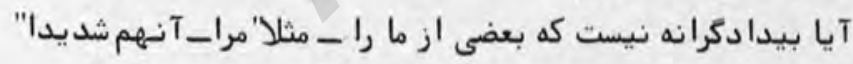

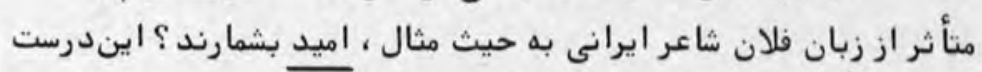

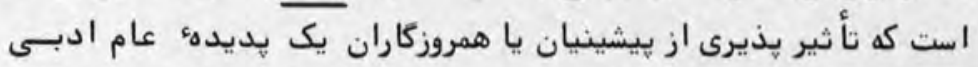

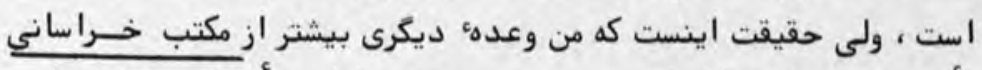

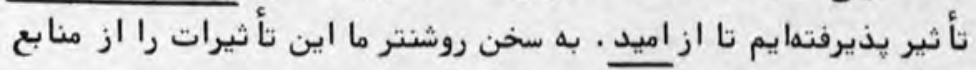

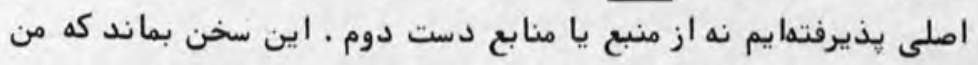

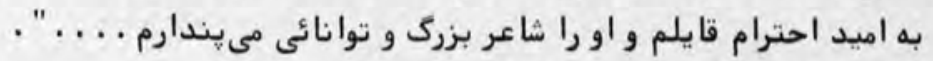


* آقاى دكتر محمدرضا باطنى ، استاد دانشكاه و همكار قديمى سخن

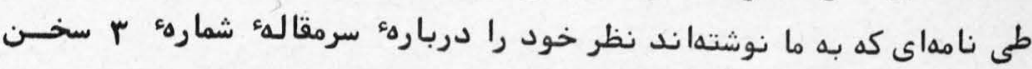

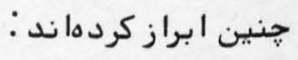

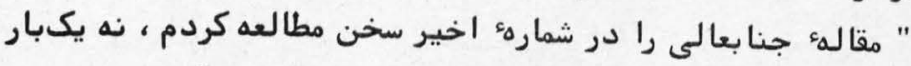

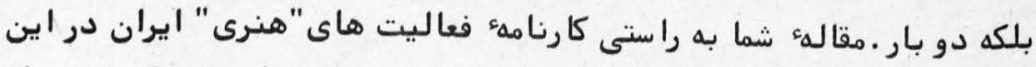

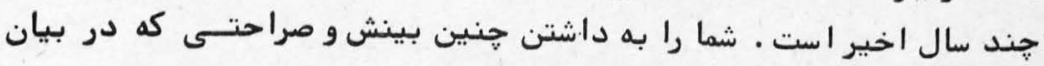
حقايق داريد صميمانه تبريك مىكويم . "

* آقاى هرنوت ويندفور ،رئيس قسمت مطالعات خاور نزديك دانشكاه

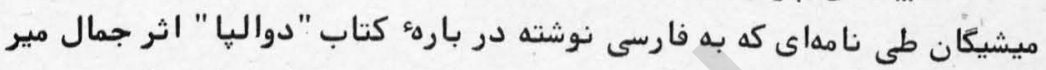

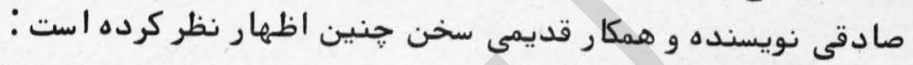

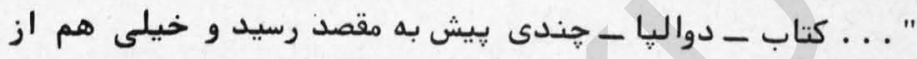

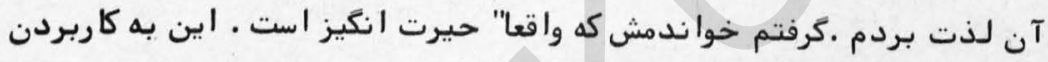

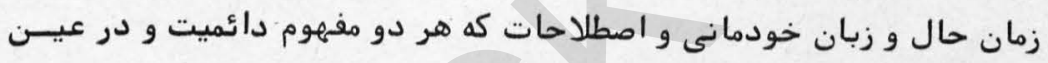

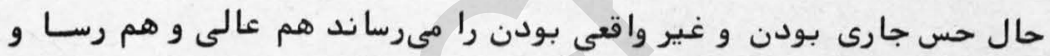

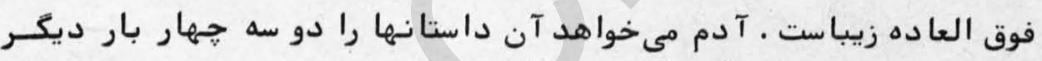

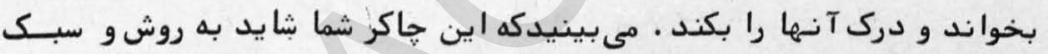

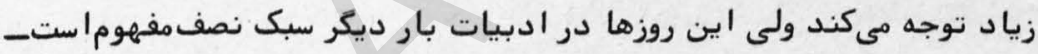

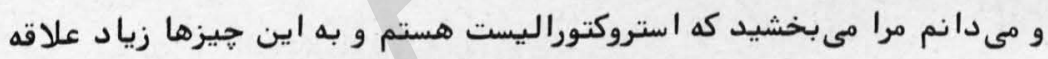

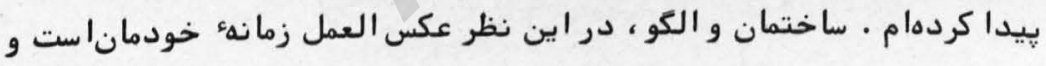

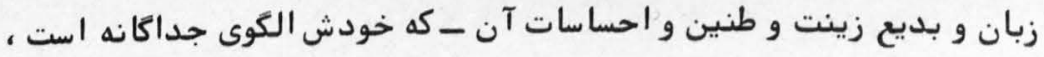
كسترده بر روى الكوىاصلى ،مانند Hologram كه با وجود اينكه يكى بمى ماند

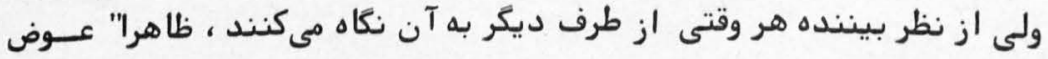

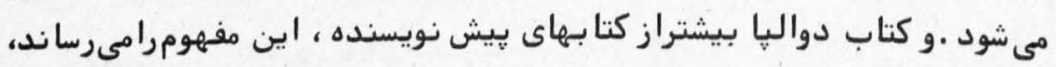

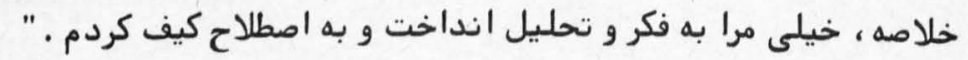




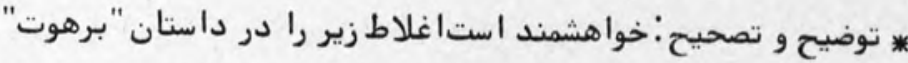

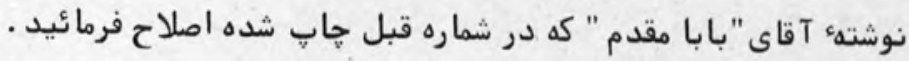

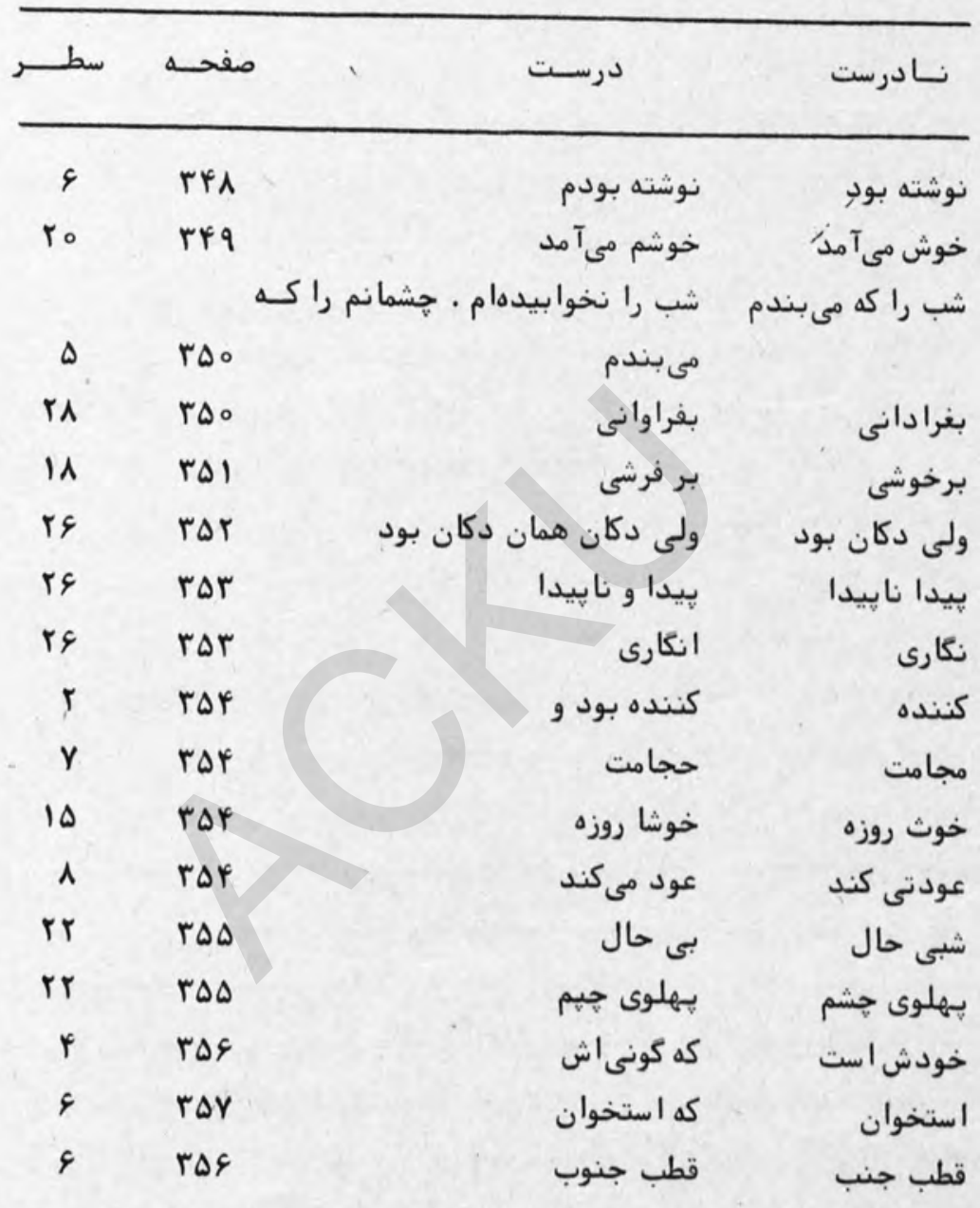




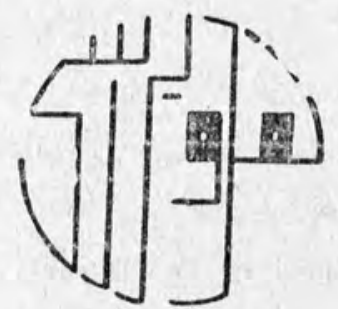

مولفان : على اشرف صادقـــى

غلامرضا ارزئك

\section{وزاوت آموزشو هيرورش

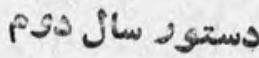

T.0. زش متوسط عمونى

فرهنتصوادب

از قرار معلوم كتاب بالا را وزارت آموزش و يرورش جزو كتا بهاى

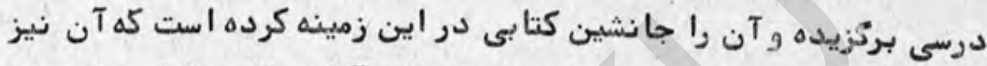

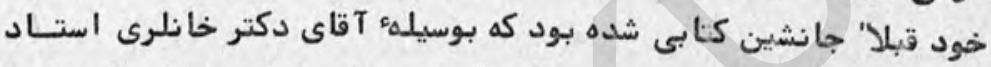

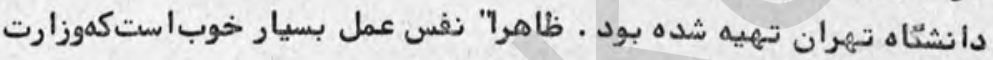

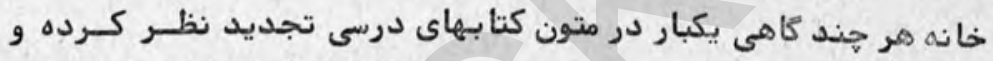

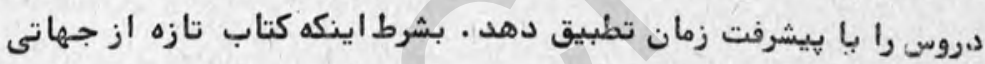

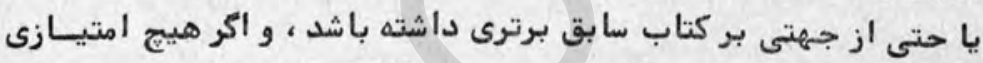

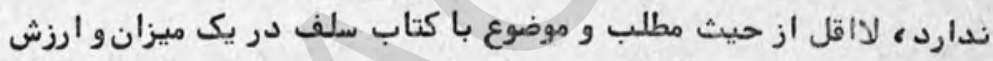

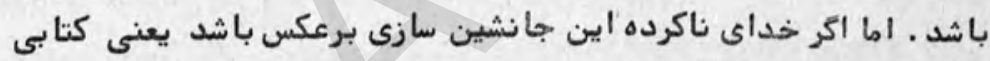

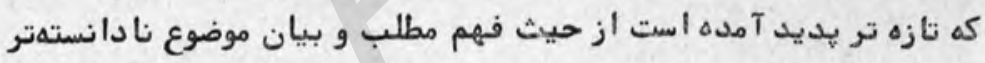

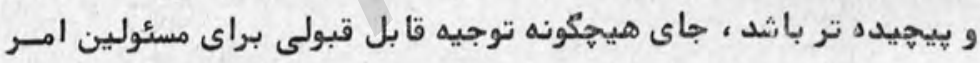

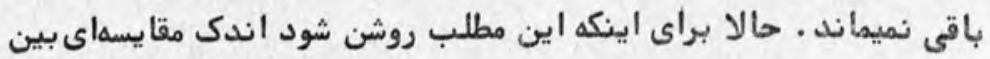

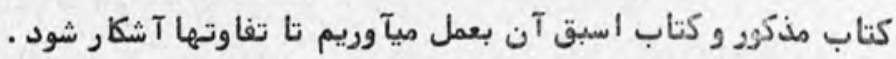

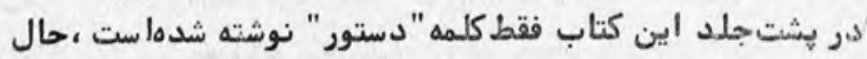

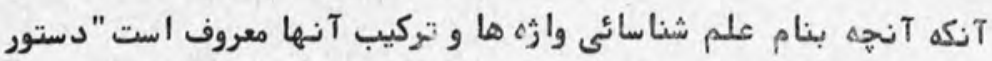

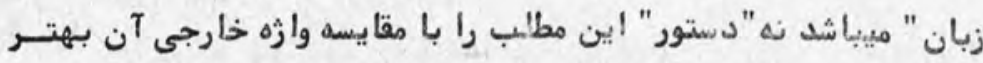

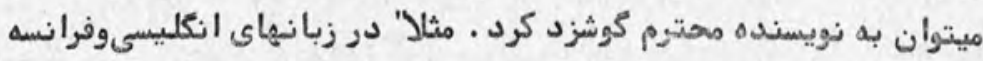

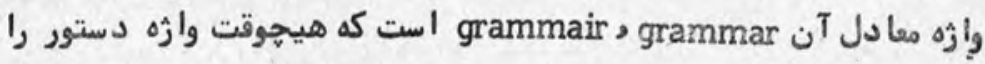


نميتوان بصورت كرامر تربهه كرد بلكه وازٔه ميا دل دستور در أين زبسانها

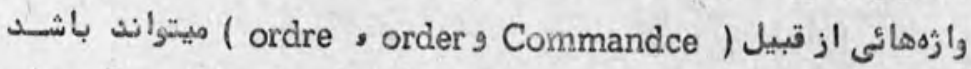

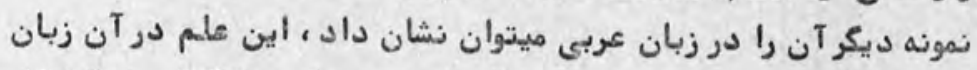

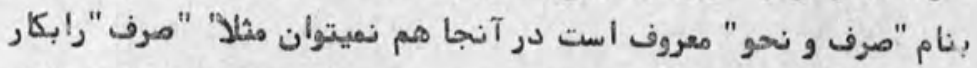

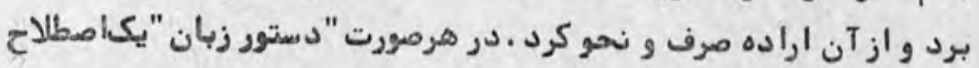

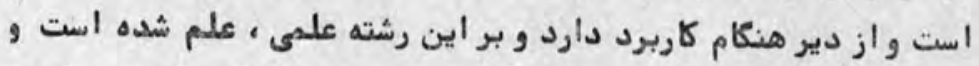

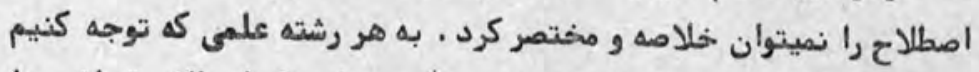

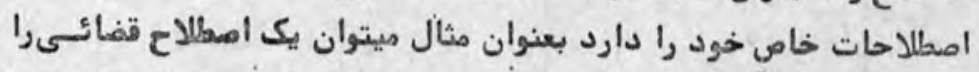

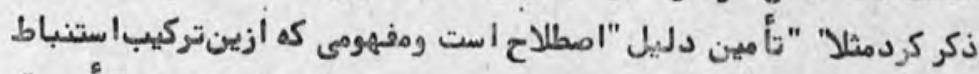

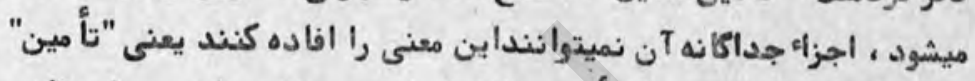

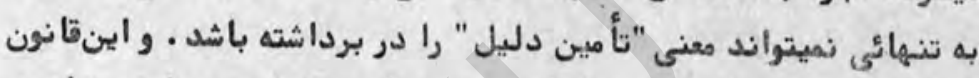

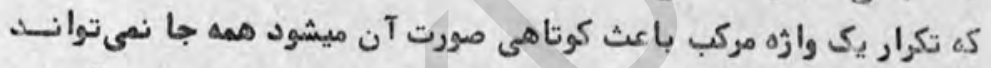

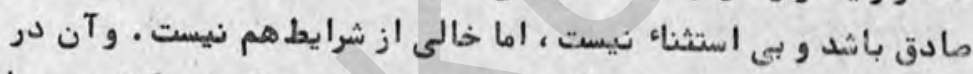

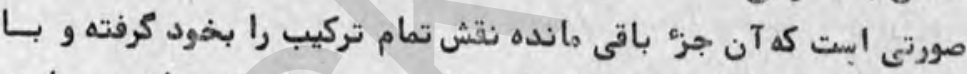

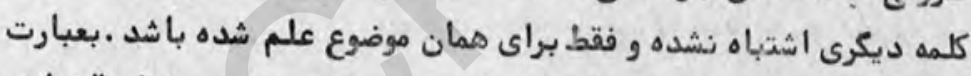

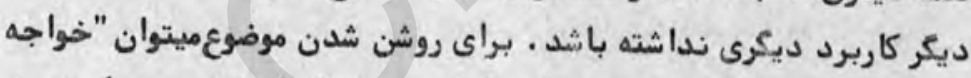

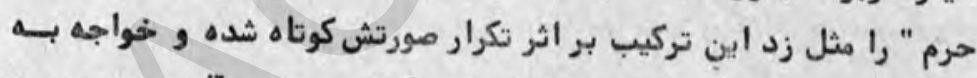

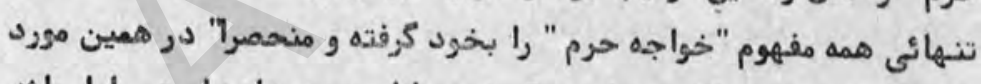

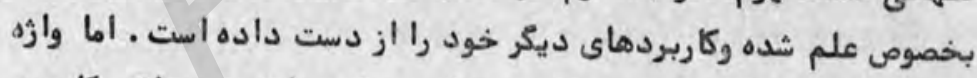

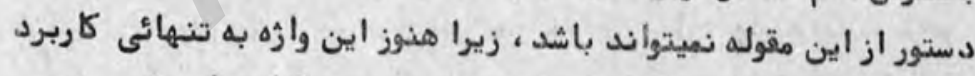

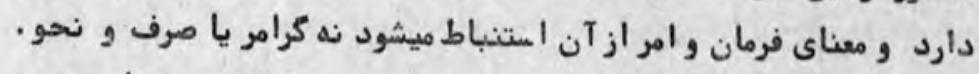

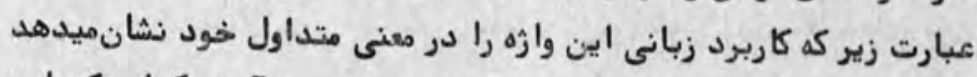

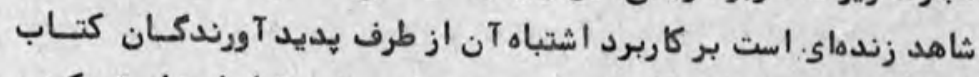

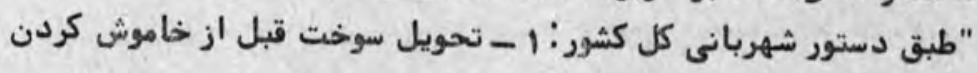

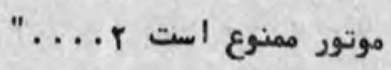

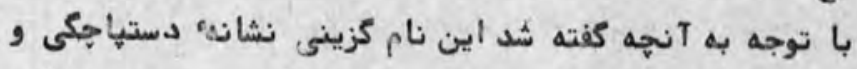

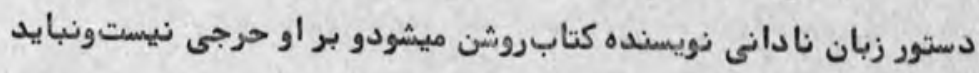

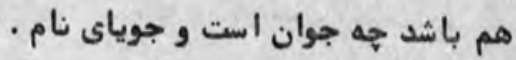




\section{1}

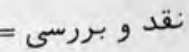

اما اولين درس ابين كتاب از جمله و ساختمان آن شروع شده و در

تعريف جمله جنين آمده است : " جمله سخنى است كه حداقل داراى دو

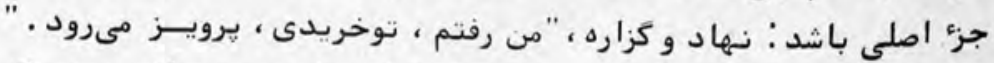
ضعف اين تعريف بوضوح ييداست كه فقط شا مل همان نمونه هائى ميشودكه

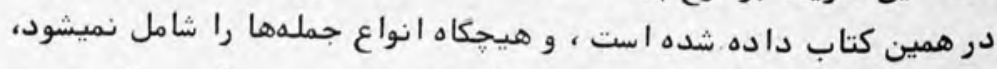

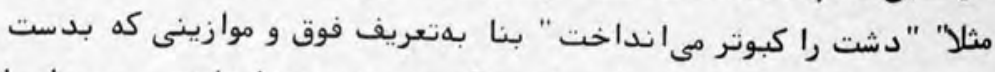

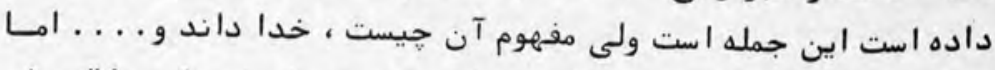
در كتاب دستور زبان دكتر خا نلرى جمله جنين تعريف شده است : " جمله مجموعداى از كلماتا ست كه بر روى همد داراى يك مفهوم تمام و كا مل باشد."

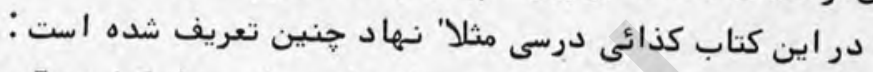
نهاد كلمه يا كروهى از كلماتا ست كه در ساختمان جمله همراه كزارهمى آ يد كاني

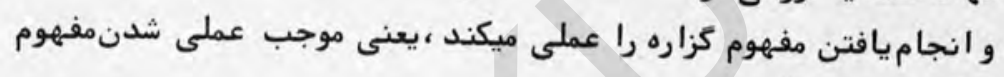

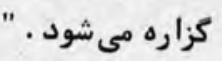

جند نا آكاهى دراين تعريف بكار رفته است - 1

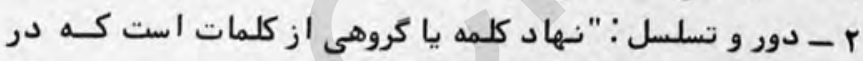

$$
\text { ساختمان جمله همراه كزاره مى آيد . " }
$$

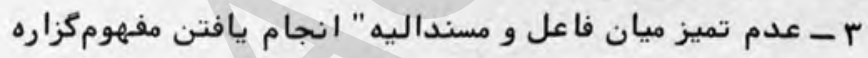
را عملى ميكند . " زيرا ممكن است كزاره حالتى باشد كه اصلا" در آن كارى تمان

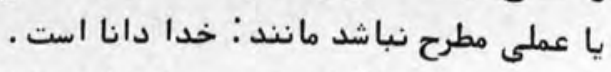
اين مسائل كه موجب سركردانى و اشتباه كارى تازه كاران ميشود حتى در ا بتدائى ترين كتابـهاى دستور زبان رعايت شده وبه آنها استشعار داشتهاند ، حالا اكر به دستور زبان دكتر خانلرى مراجعه كنيم دراين باره

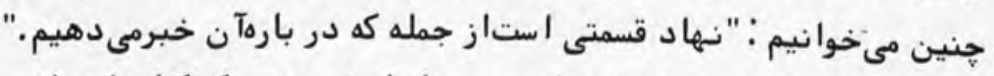
براستى هرا و هه دوستى ها و نادوستى ها باعث ميشود كه كتا بـهاى واضح

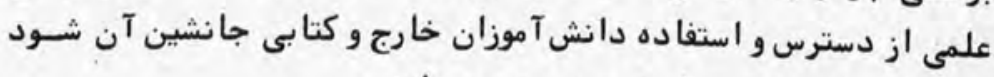

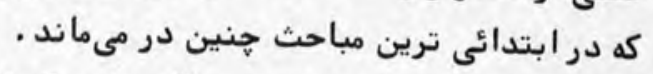
آنهه دربالا بحث شد مطالبى استى سته فقط از نيم صفحهنخستا ين 
كتابدرسى حاصل شدها ست ،مشت نمونه خرواراست .من دريغو بسيار دريغ

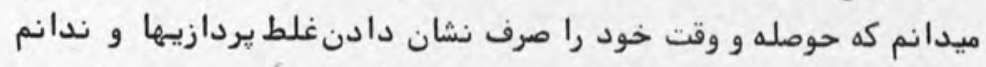

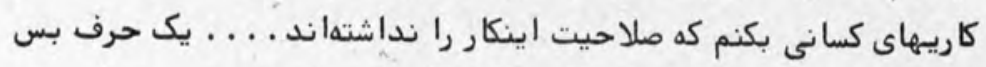

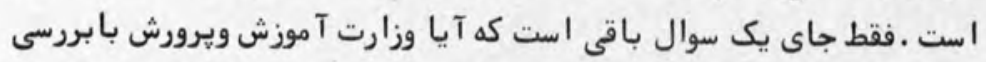

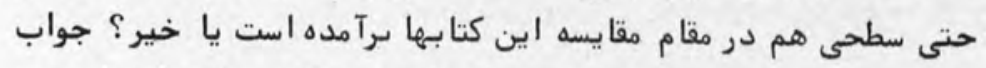

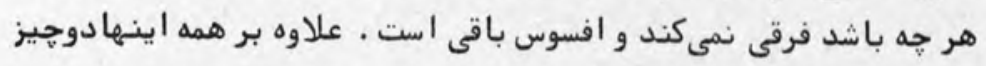

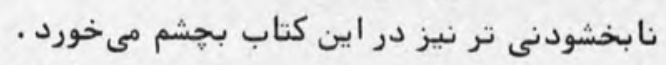

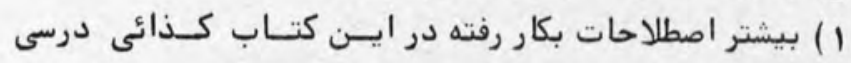

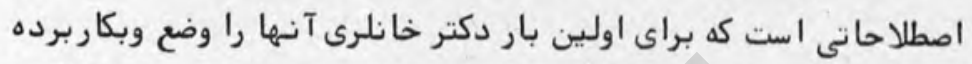

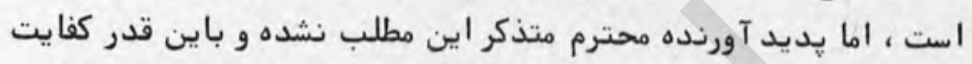

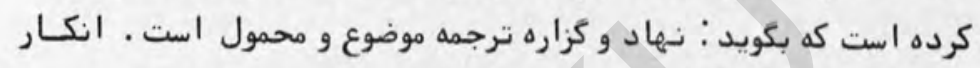

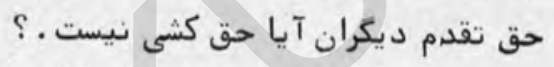

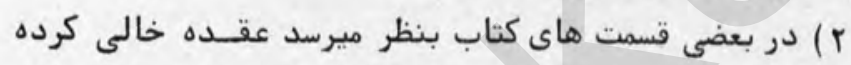

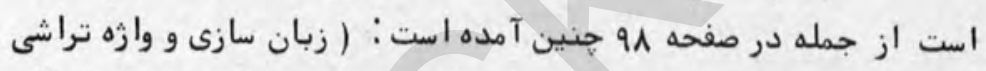

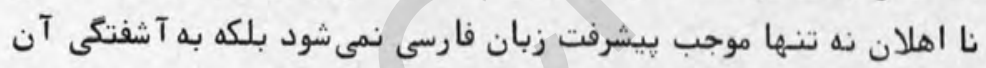

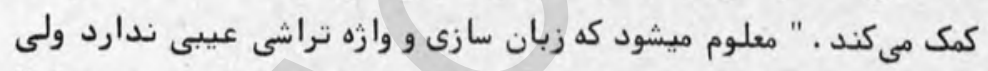

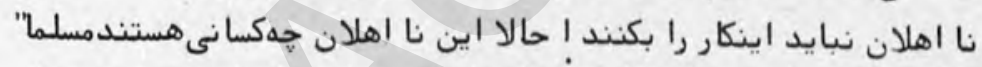

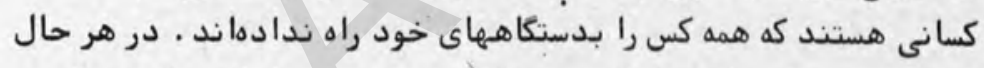

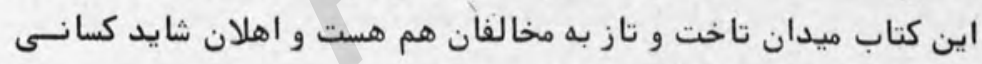

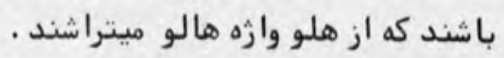

جواد برومند سعيد 


\section{نكاهى به هيجلات}

مجلهُ دانشكدة ادبيات وعلوم انسانى دانشغاه تهر ان ان اندان

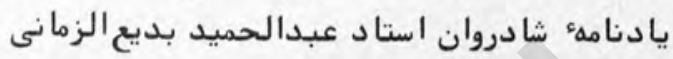

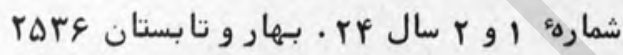

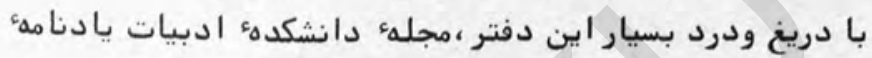

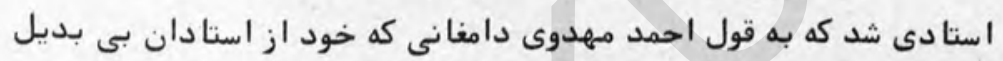

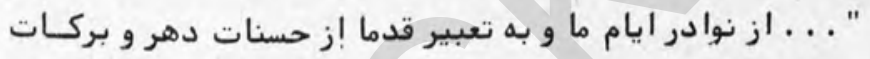

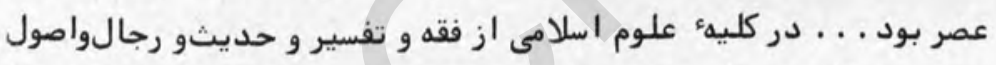

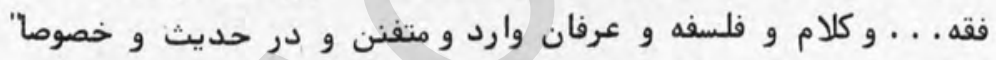

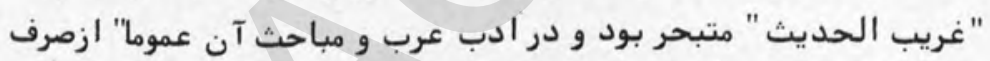

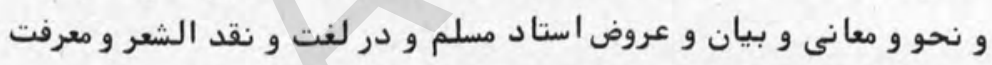

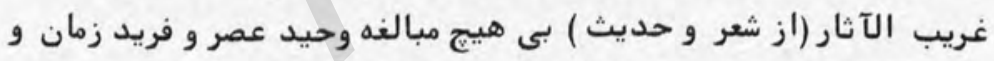

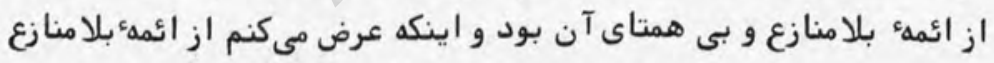

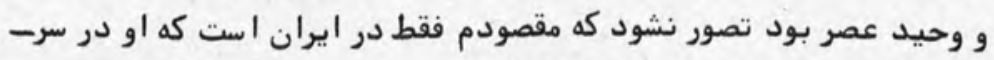

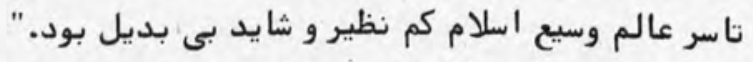

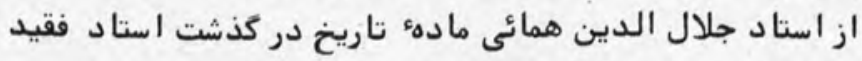

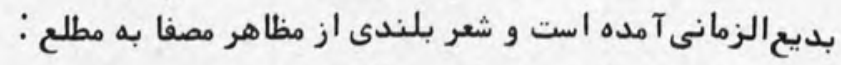

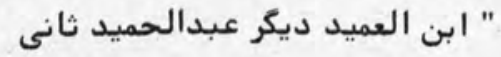

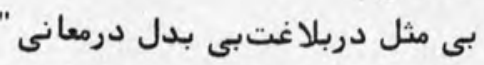

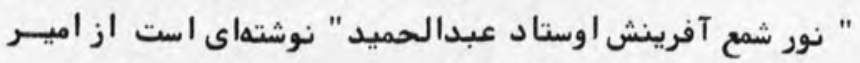


محمود انوار و شعرى به مقطع :

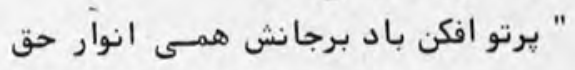

عالمان را مهر حق هاداش اش عقبى كردهاند

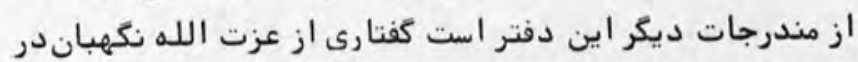

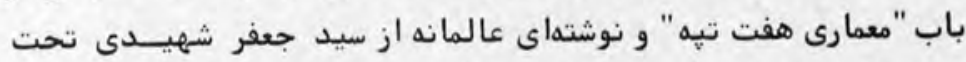

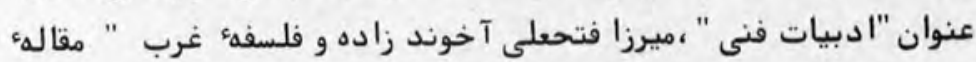

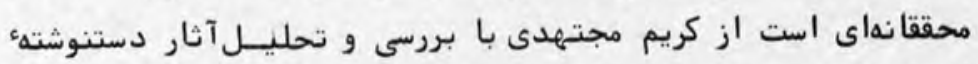

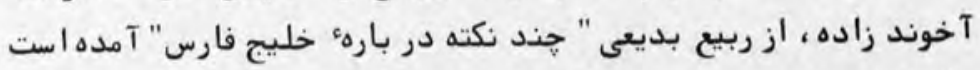

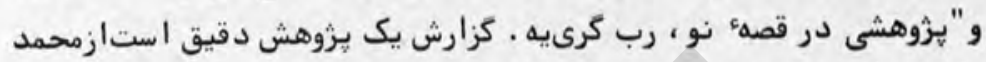

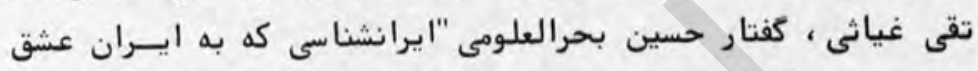

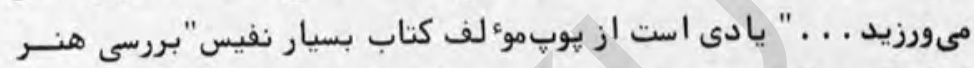

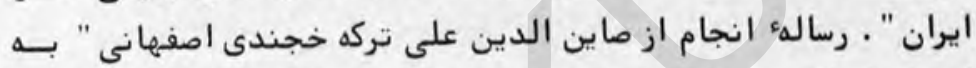

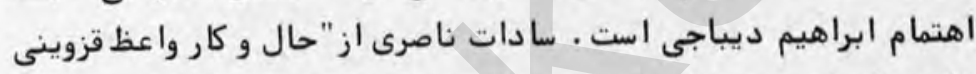

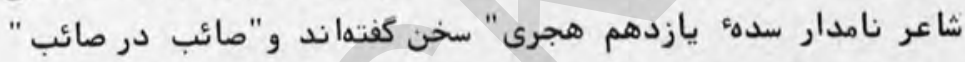

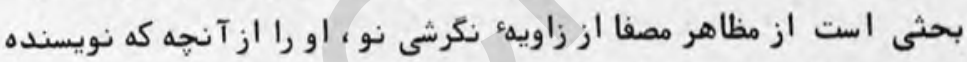

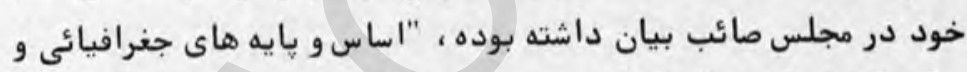

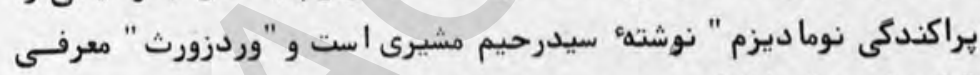

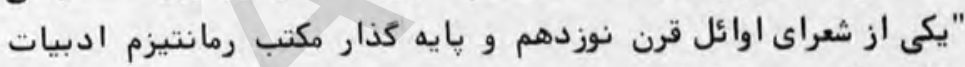

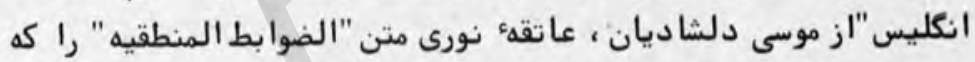

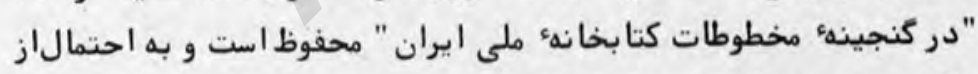

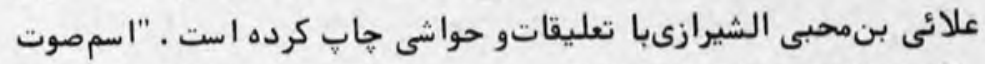

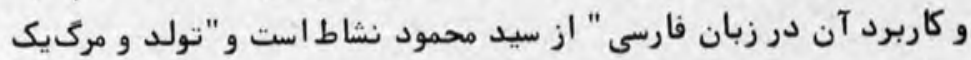

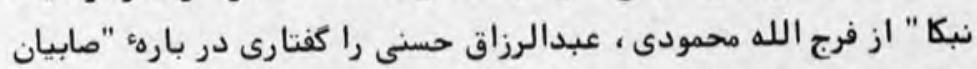

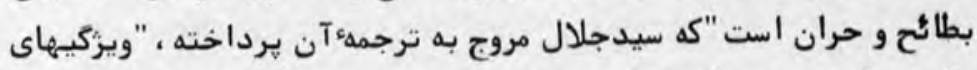

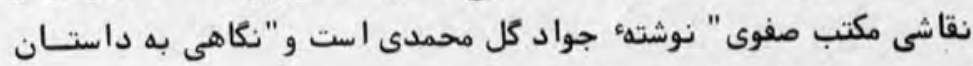

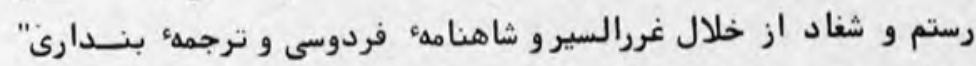

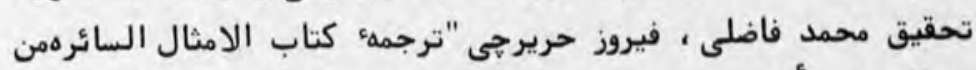

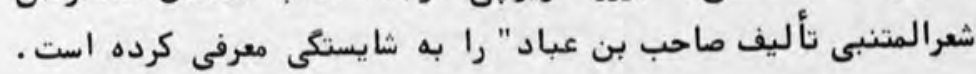




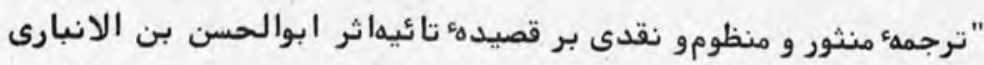

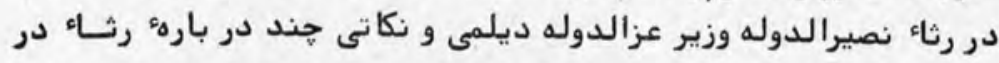

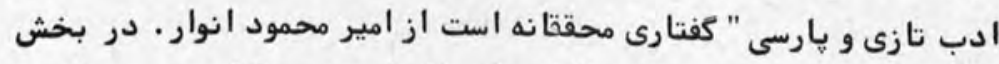

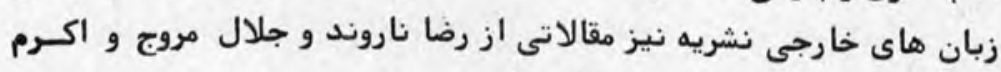

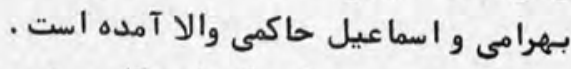

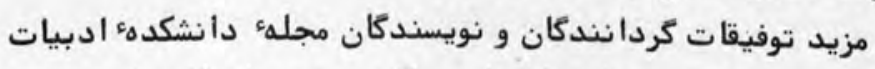

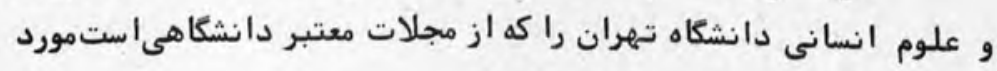
Tزو است.

\section{نامة آستان قدس}

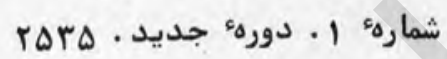

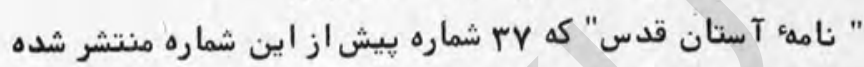

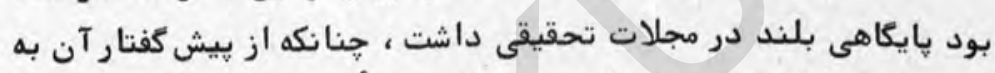

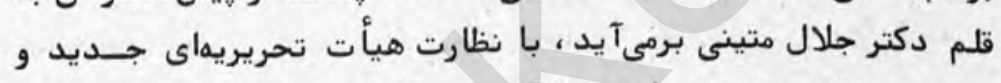

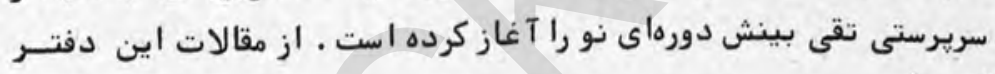

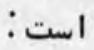

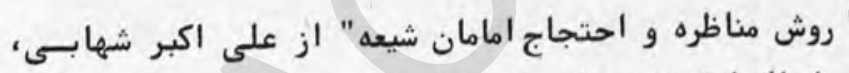

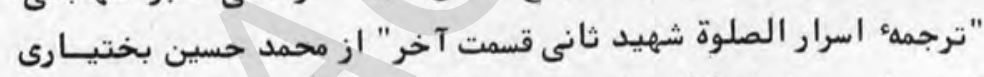

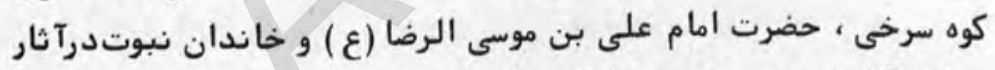

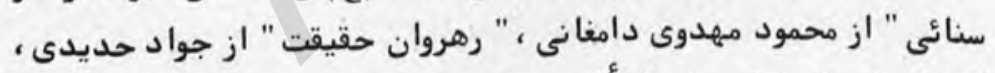

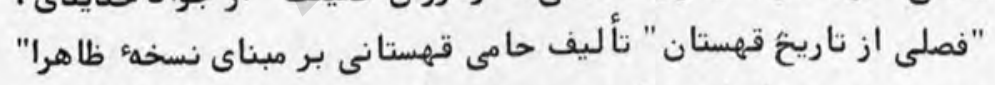

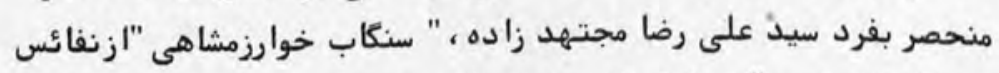

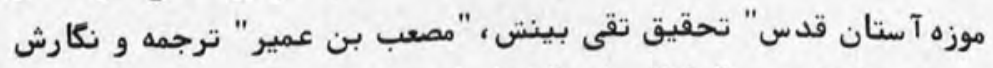

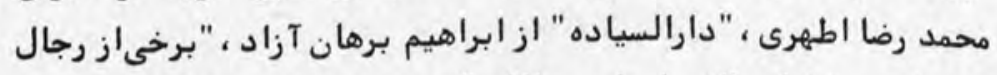

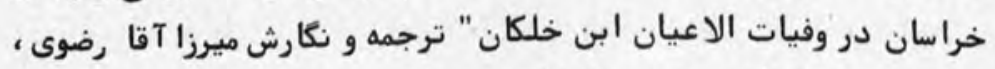

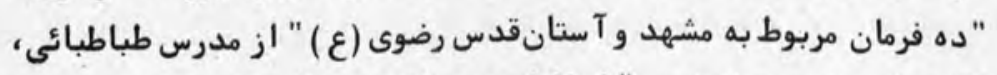

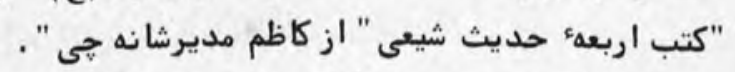

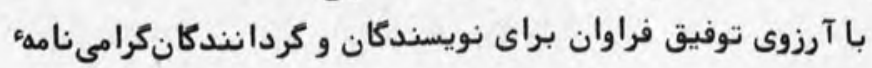


آستان قدس ، انتشار مرتب آن را اميد مى داريم .

\section{فلسفه}

نشريهء اختصاصى كروه آموزشى فلسفه دانشكده ادبيات و علوم

rors انسانى تهران شمارهء

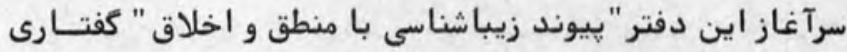

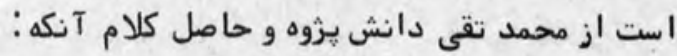

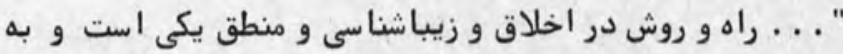

كفتهء افلاطون زيبايى همان درخشندكى راستى و درستى است " .

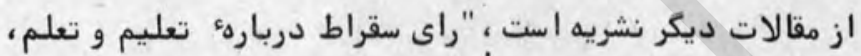

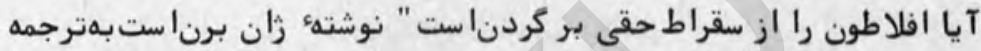

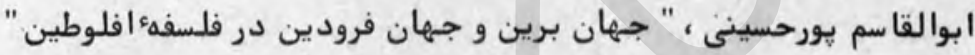

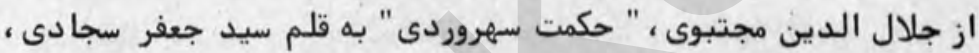

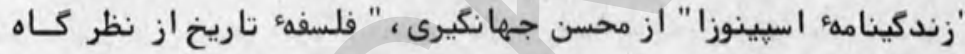

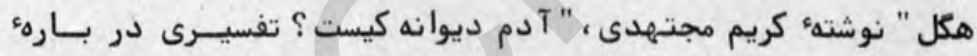

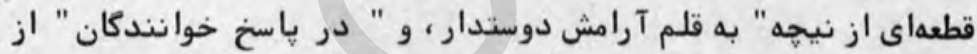

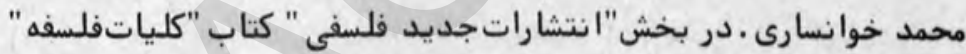

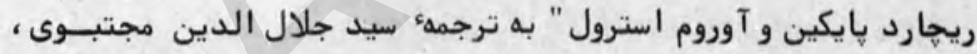

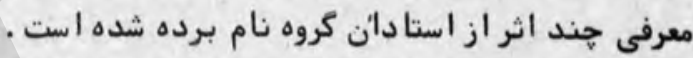

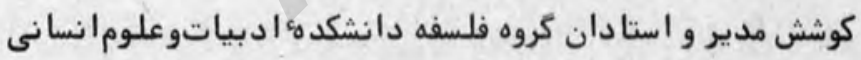
دانشكاه تهران ستودنى است .

\section{فر هنَع الير ان زمين}

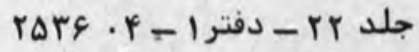

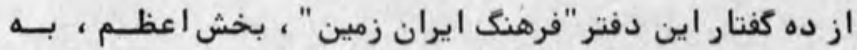

آكاهيهاى سودمند دربارهء قـم اختصاص يافته است و و به اعتبارى ، تكملهء

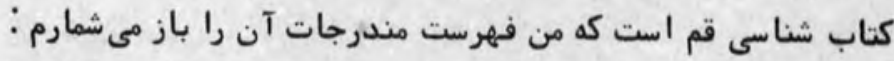

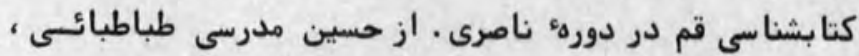



كاهى به مجلات "كتا بحهء احوالات دارالايمان قم " نوشتهء محمد تقى بيك ارباب بمكوشش

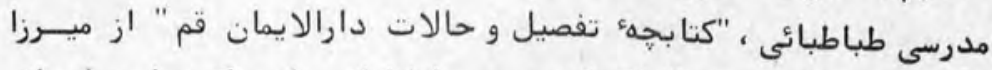

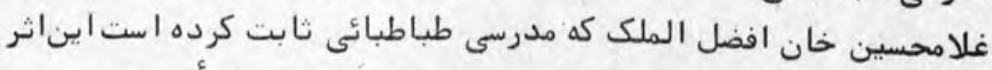

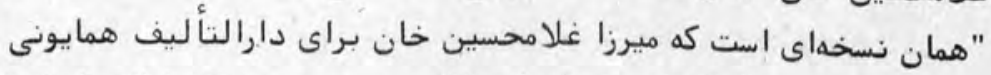

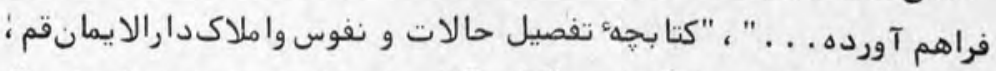

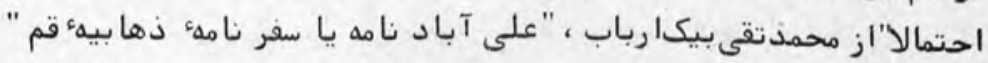

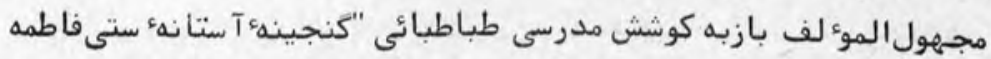

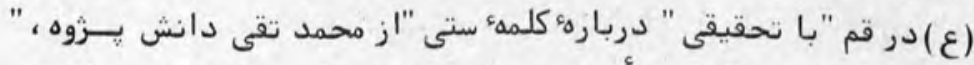

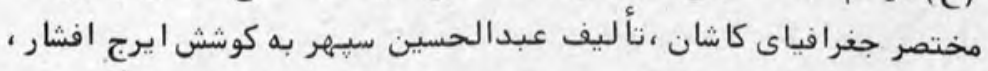

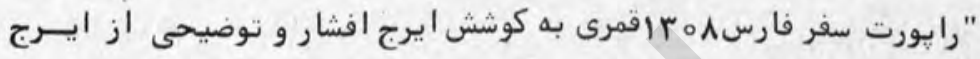

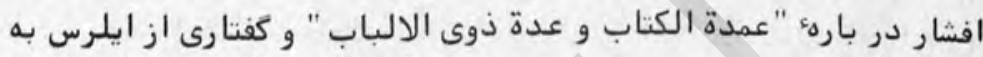

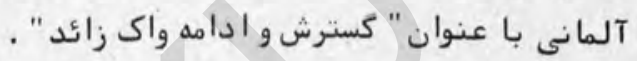

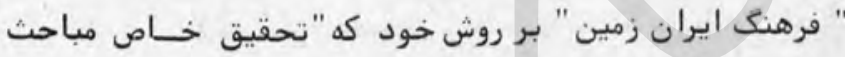

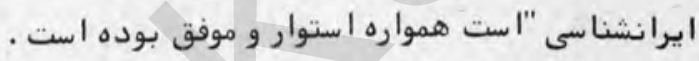

\section{نشر ئه دانشعأه ادبيات و علوم انسانى}

\section{دانشكاه اصفهان}

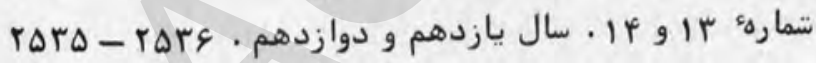

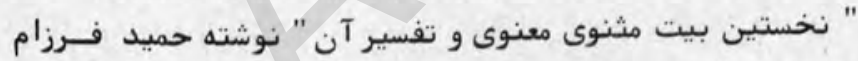

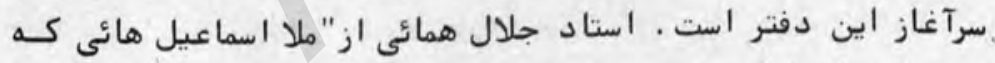

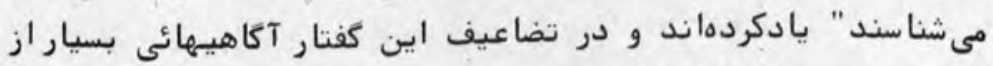

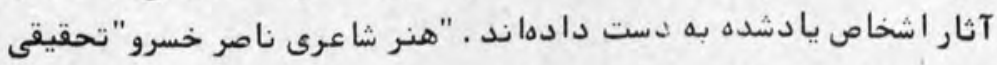

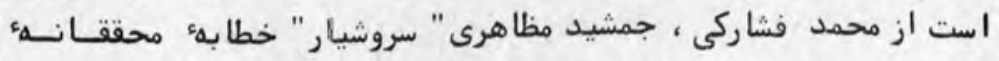

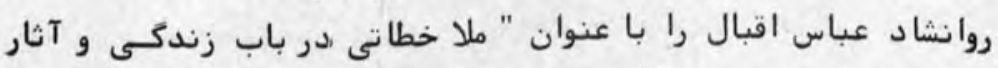

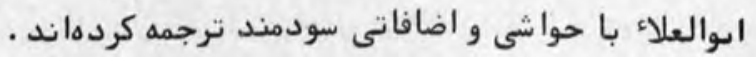

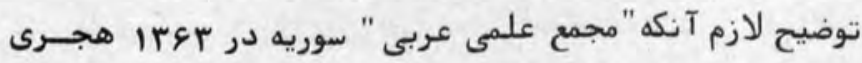

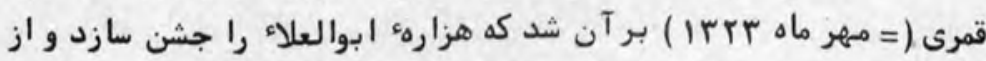

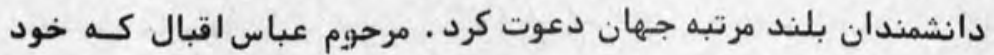


سالهها يِيش از ابن تاريخ عضويت آن مجمع را بر عهده داشت ، خطابهاى

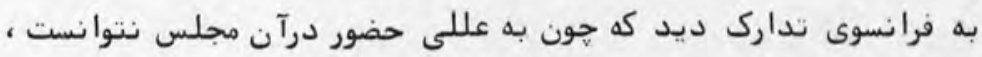

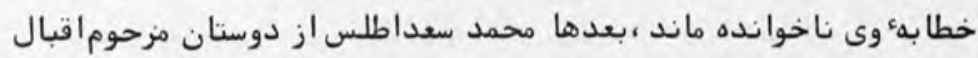

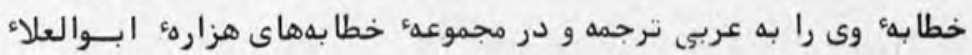

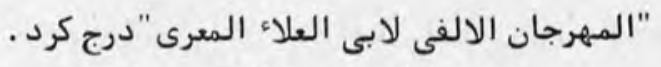

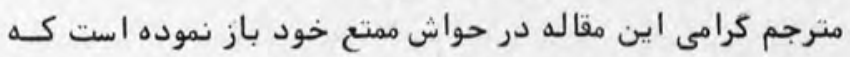

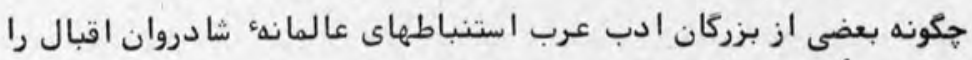

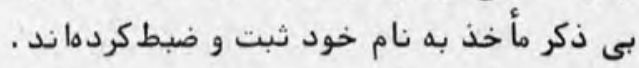

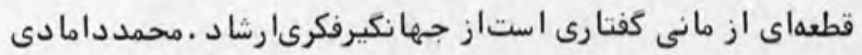

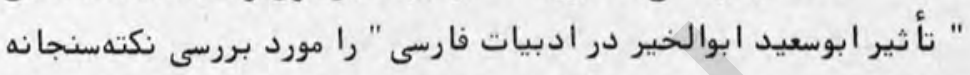

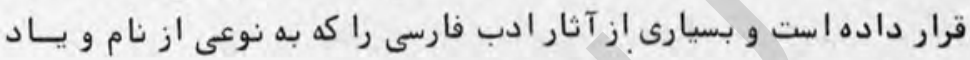

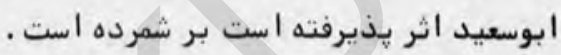

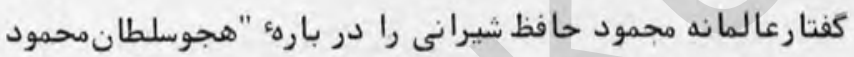

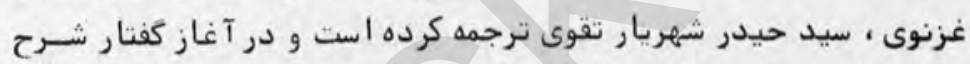

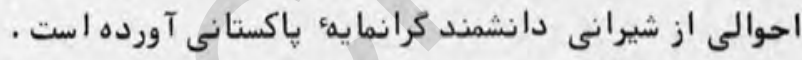

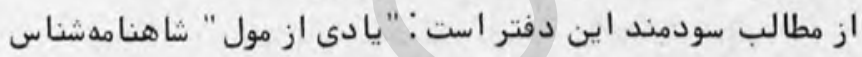

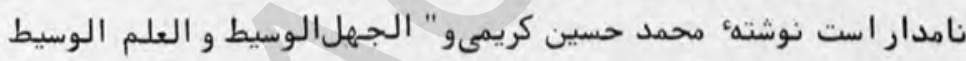

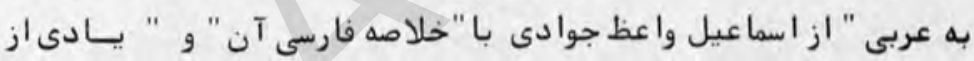

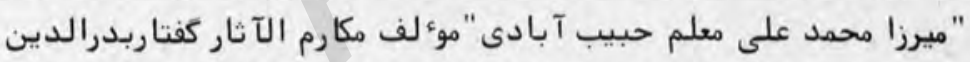
كتابى و نوشتهء فضل الله ضياء نور در بارهء "آيت الله حاج آ قارحيمار ارباب"

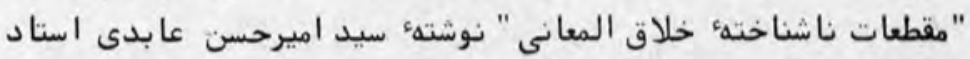

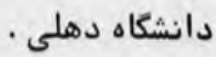

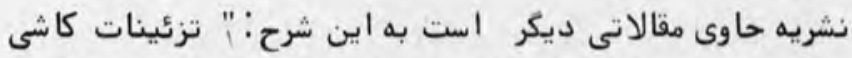
كارى در مسجد جامع اصفهان ، از لطف الله هنرفر" ديم كارى در در ايران"

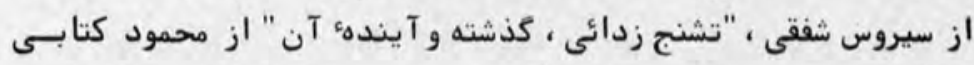

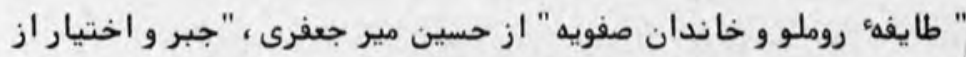

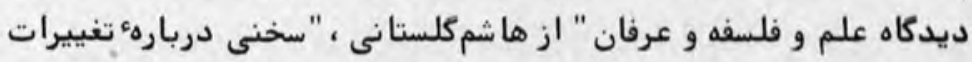

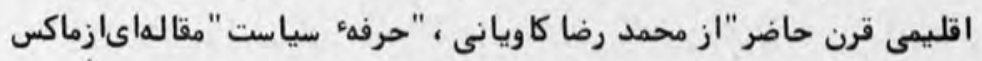


ค११

نكاهى بـ مجلات.

وبر به ترجمهء هرمز انصارى ، " ارتباط آب با فعاليتهاى انسانى در ايران"

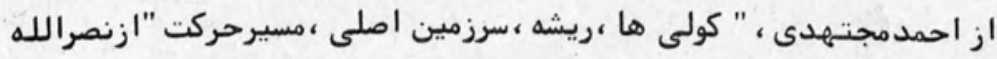

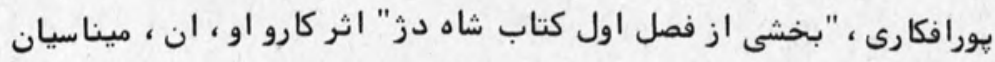

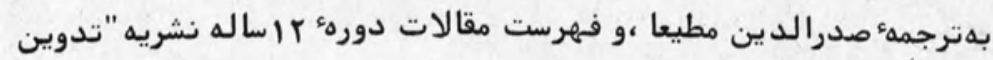

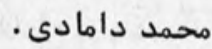

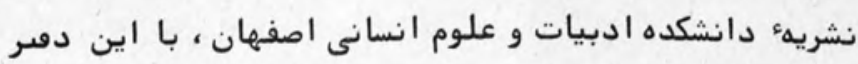

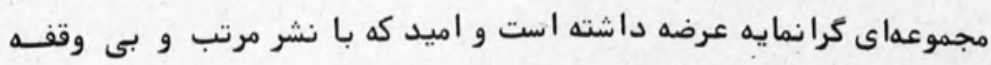

قرين توفيقات بسيار باشد . 


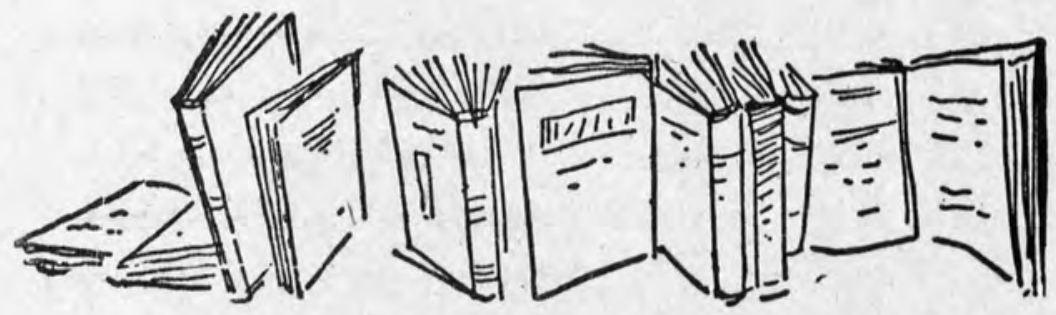

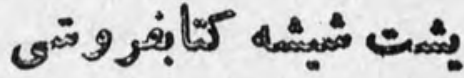

\section{كفتار در آزادى}

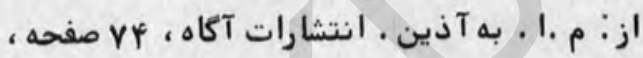

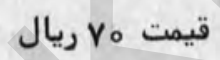

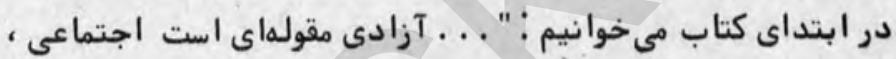

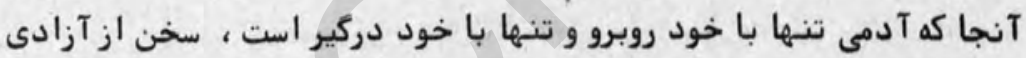

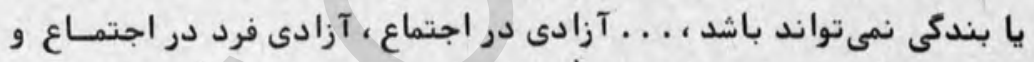

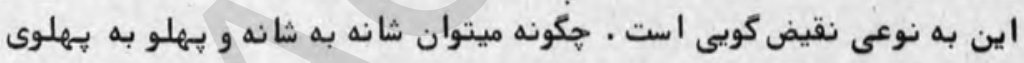

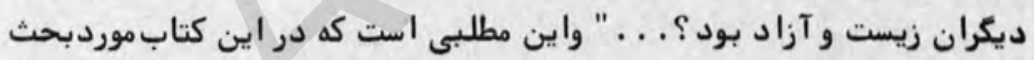

است.

\section{هر اس}

مجموعه داستان از جمال ميرصادقي، ، انتشارات آكاه ، مبا صفحه

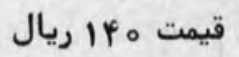

جمال ميرصادقى نويسنده و همكار قديمى سخن ،ازجمله قصهنويسانى

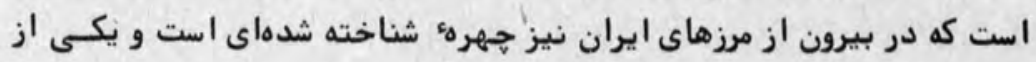

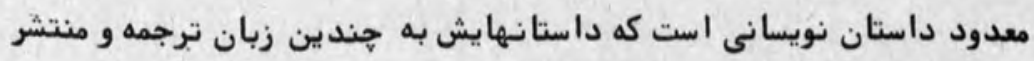

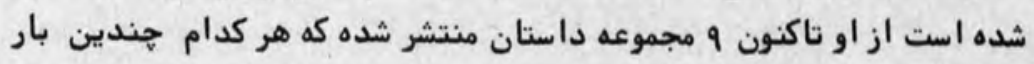

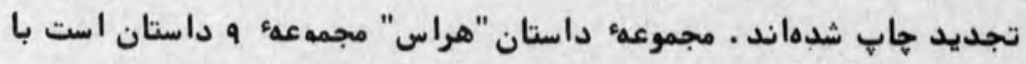




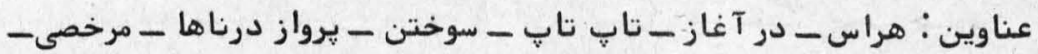
ديكه مثه تختى نمياد ـ باختم ، باختى ، بردند إن - خرجسونه

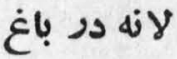

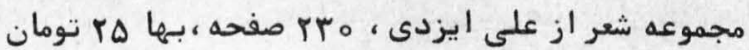

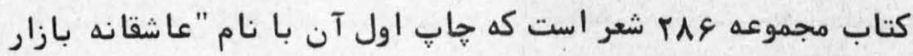

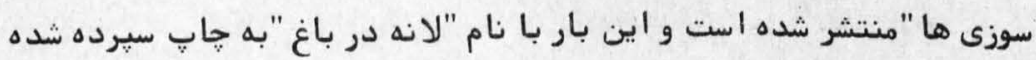

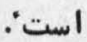

طوطى سبز هندى - نو كى طال نقى نتو هبال ـ باغ ستارهها

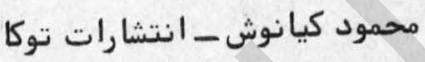

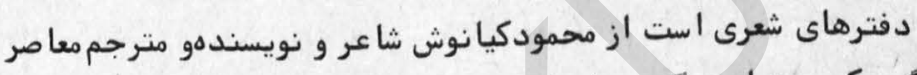

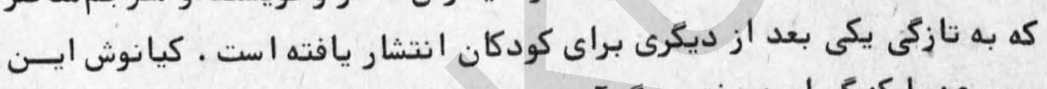

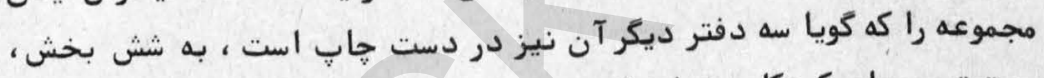

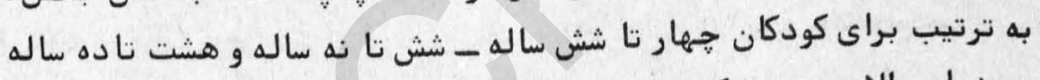

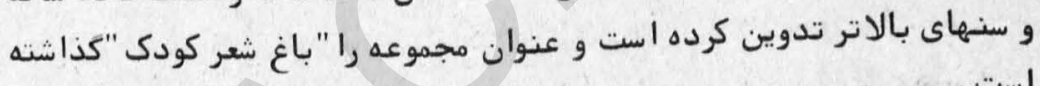
كيانوش يكى از معدودشاعرانى استكه اشعارى كه برايكودكان سرودهه،

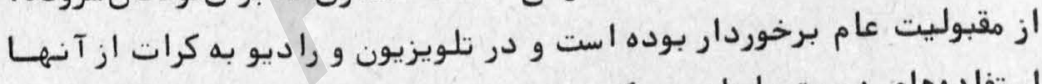

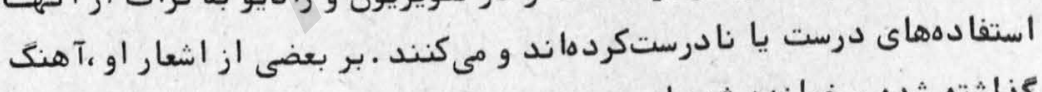
كذاشته شده و خوانده شده است.

شعرها روان وشيرين و مناسبكودكان است أس اسعى شدهكه كلمات شكسته

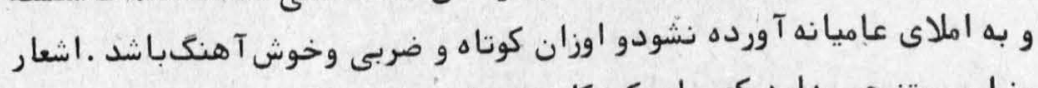

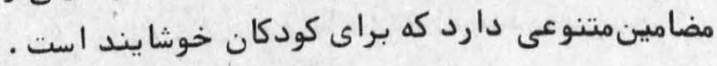

\section{الدزيعه الى تصانيف الشيعه}

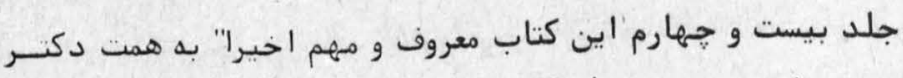

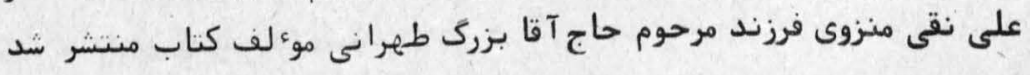


و انتشار اين مجلد كه ظاهرا" جلد ماقبل آخر اين تأليف بزرك است خــود

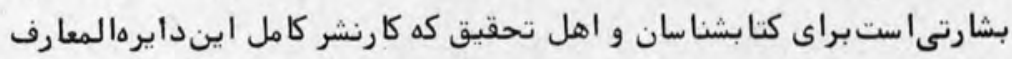

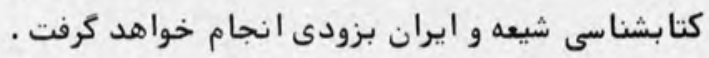

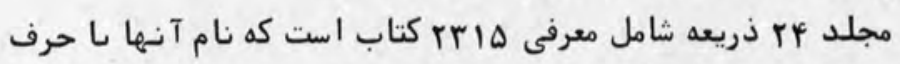

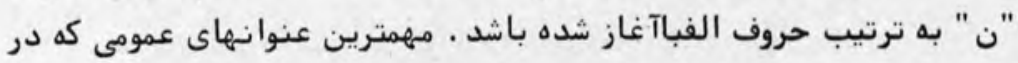

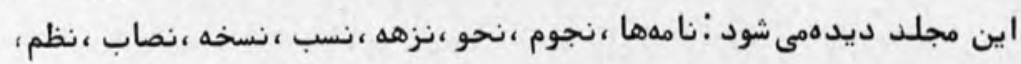

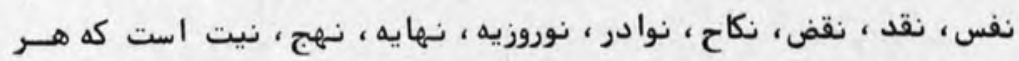

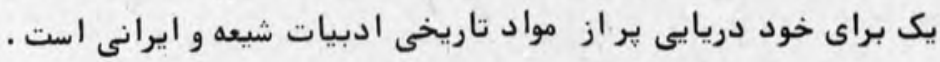

\section{بادفاشتهاى يوار.يس.} از: حسين مهرى ، بع ب صفحه ، انتشارات آرمان قسمت rVD ريال

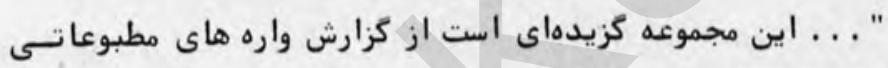

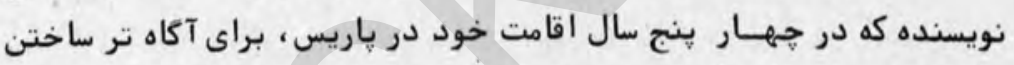

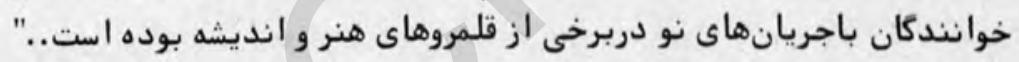

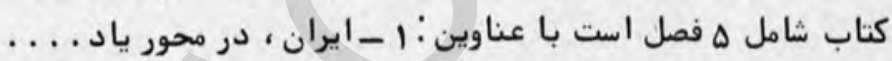

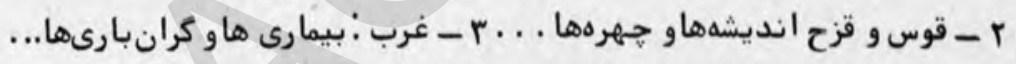

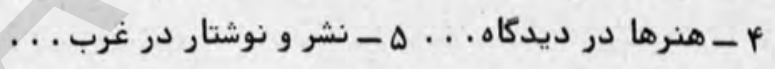

\section{وادى هفت واد}

$$
\text { بحثى در تاريخ اجتماعى و آثار تاريخى كرمان }
$$

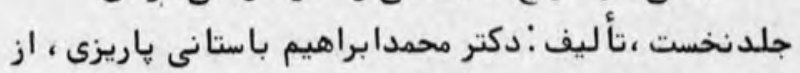

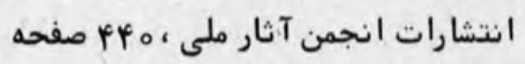

" . . . . . "

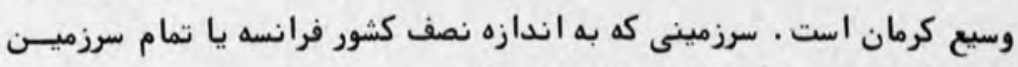

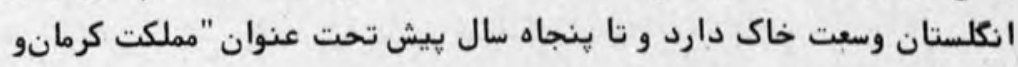

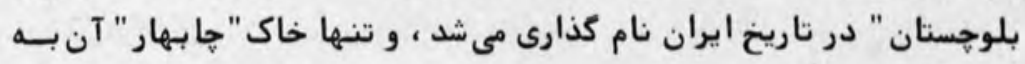

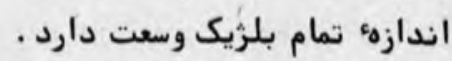


$\Delta \circ r$

دكتر باستانى تنها كرمانيى است كه تمام همت و كوشش خود رأ براى

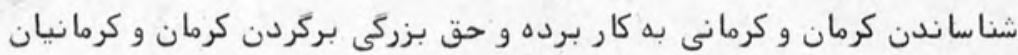

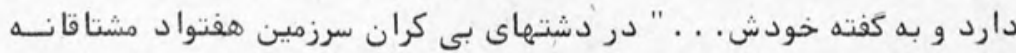

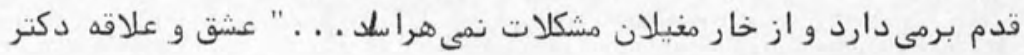

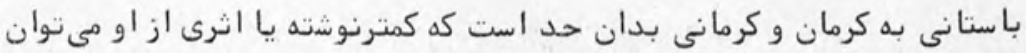

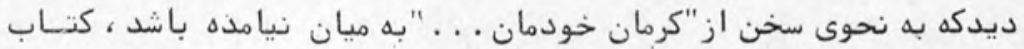

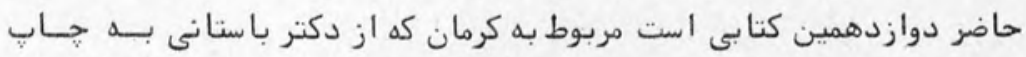

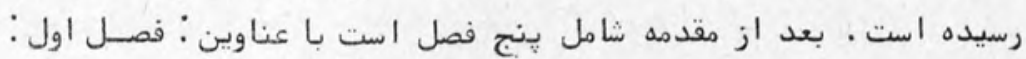

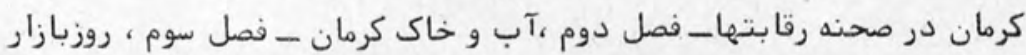

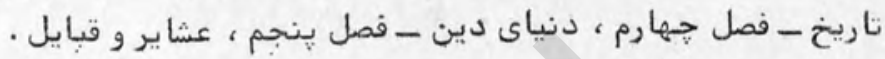

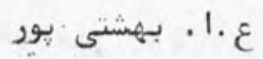




\section{نامه يزو هشكله}

نشريه بزوهشكدهعلوم ارتباطىو

توسعه ايو ان

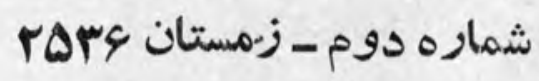

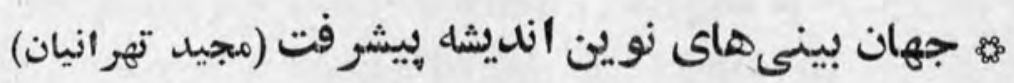
\$ سير توسعه در خاور ميانه (نيكى كدى / م قائد) ه" ياسخغو سازى نظام آموزشى (يحيى فيوضات)

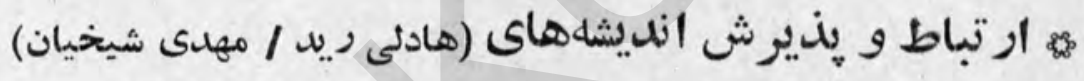

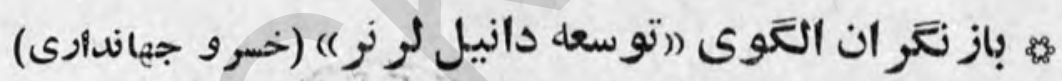

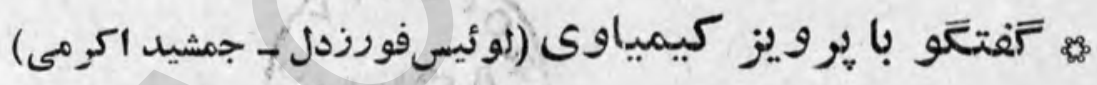
مه تلويزيون و تاثير آن در رفتار اجتماعى(مجيد تهرانيان ـ آنابل

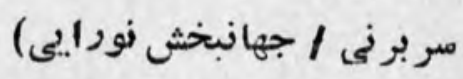
\%٪ علوم اجتماعى در آستانه ياس (على اسدى)

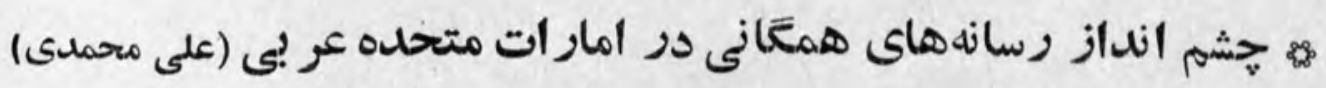
\%) در جستجوى منابع جهانى اطلاعات (محمدعلى معمار صادقى) كمة نقل كتاب (اصغر فتحى - مجيد مددى - بيزٔن حمزه لو - سعيد امير ارجمند) ـ به بعاى "أك شماره هنجاه ريال از كتابفروشىهاى معتبر بخو اهيد.

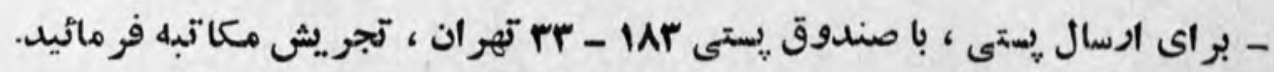




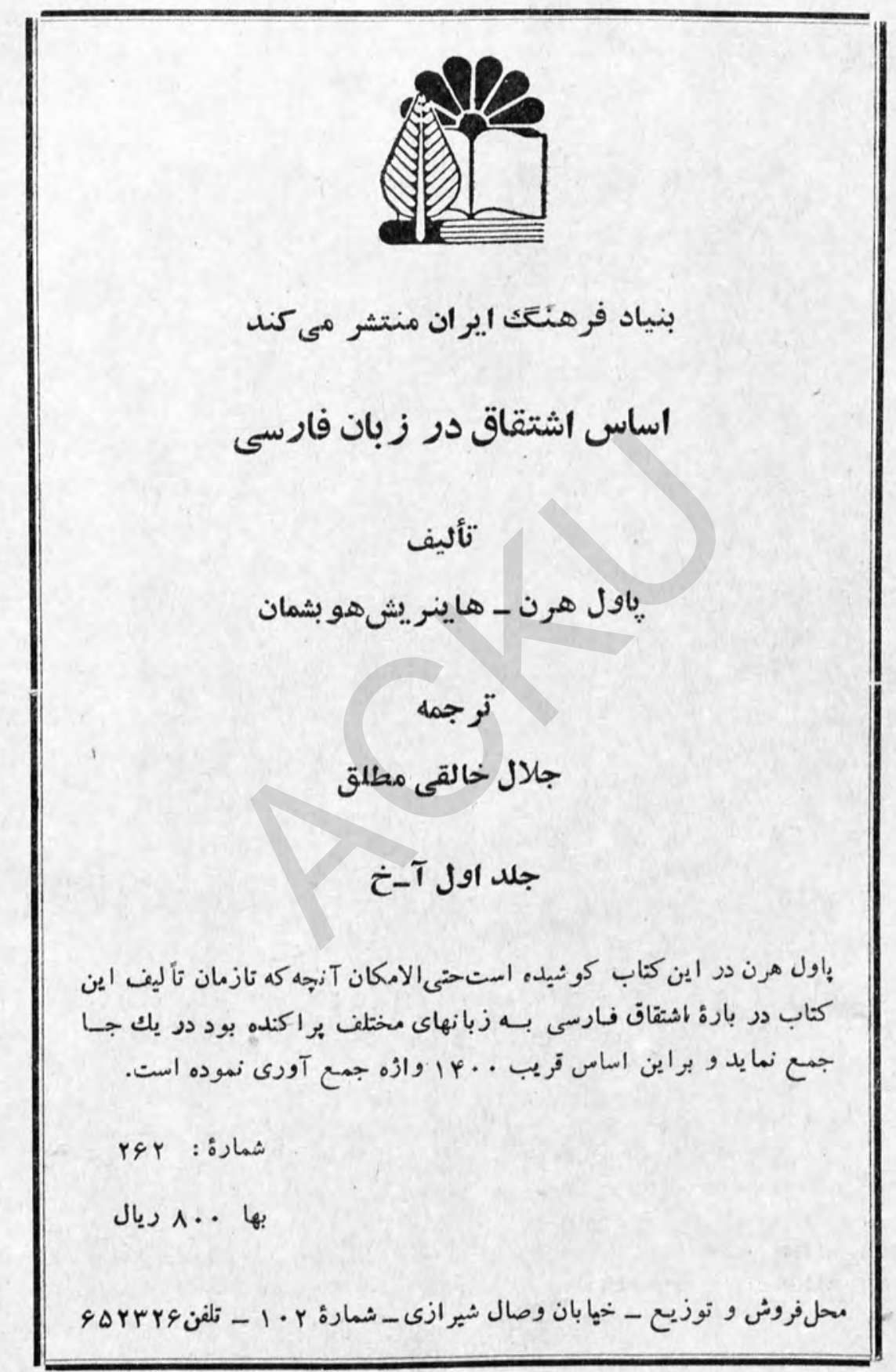




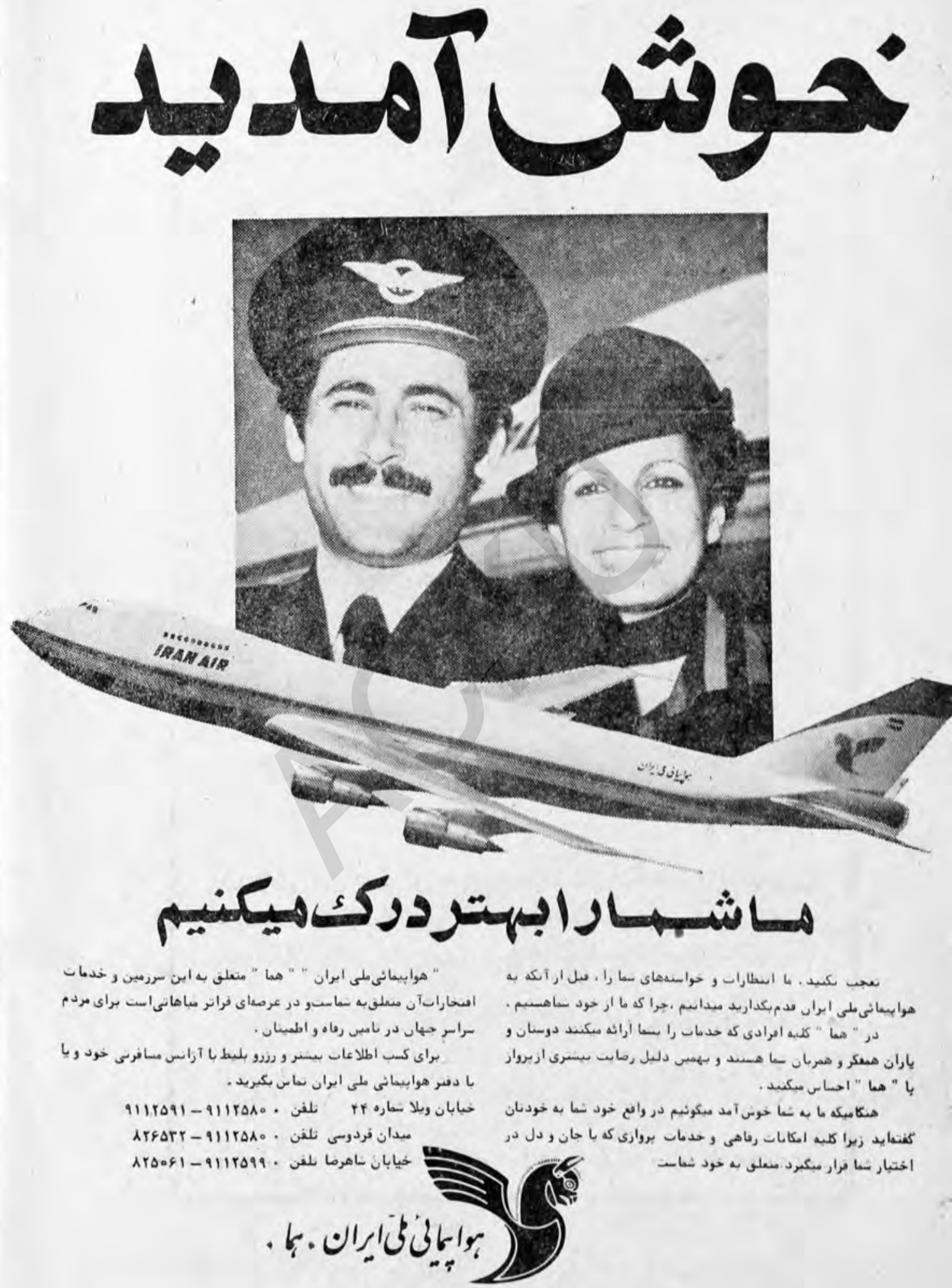




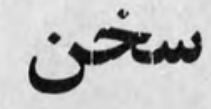

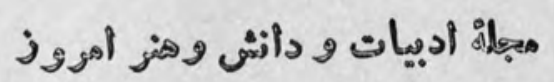

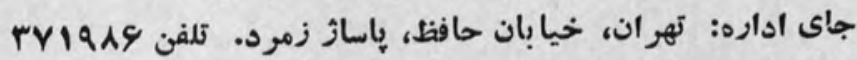

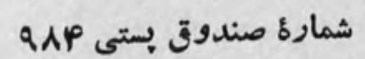

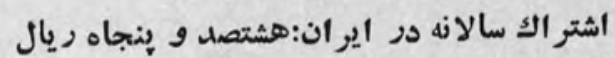

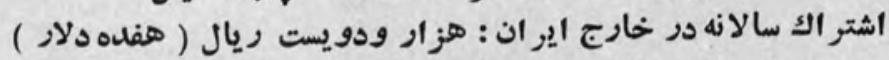

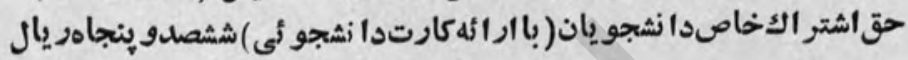

وجوه اشتر اك بايد مستقيما به عنو ان مجلك سخن بوسيلك رِاكت

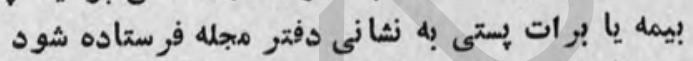

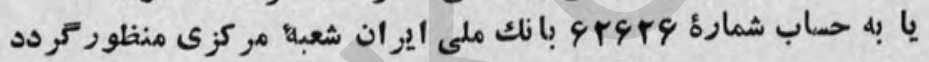

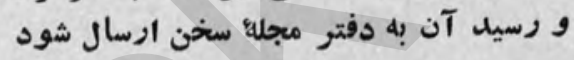

صاحب امتياز: دكتر برويز ناتز خانلرى

طبع و نقل مندرجات و مقالات اين مجله بى اجازه ممنوع است

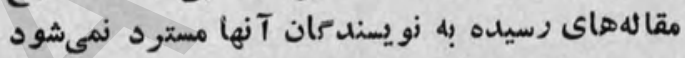

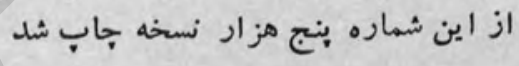

\section{SOKHAN}

Revue Mensuelle de Littérature et l'Art contemporains

$$
\text { TEHERAN [IRAN] }
$$

Abonnement à I'étranger: U. S. \$. 17. 00

$$
\text { جاب خواجه }
$$

rIPANY لالهزار، كوجه" خندان، تلفواجل 


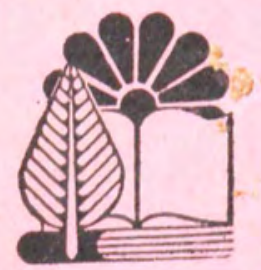

بنياد فرهنعَ إيران منتشر كرده است

$$
\text { ذخيرة خوارزمشاهى ارنى }
$$

جابٍ عكسى دو رنغك از روى نسخه خطى

$$
\begin{aligned}
& \text { تاليف } \\
& \text { سيل السماعمل جرجانى } \\
& \text { بلهوشش } \\
& \text { سعيدى سيرجانى }
\end{aligned}
$$

\section{شمارة : Prq}

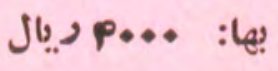

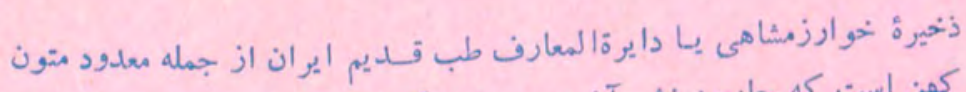

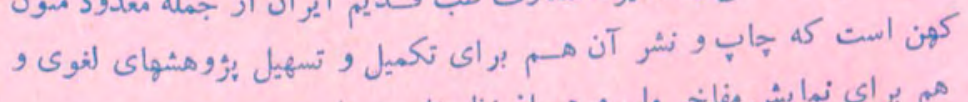

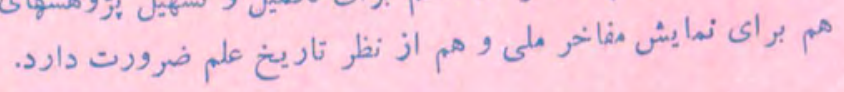

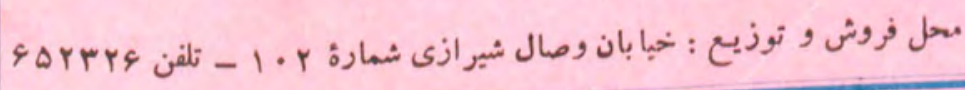

